\title{
Schoolverlaters tussen onderwijs en arbeidsmarkt 2000
}

Citation for published version (APA):

Researchcentrum voor Onderwijs en Arbeidsmarkt, ROA. (2001). Schoolverlaters tussen onderwijs en arbeidsmarkt 2000: Statistische Bijlage. ROA. ROA Reports No. 003B

https://doi.org/10.26481/umarep.2001003B

Document status and date:

Published: 01/01/2001

DOI:

10.26481/umarep.2001003B

Document Version:

Publisher's PDF, also known as Version of record

\section{Please check the document version of this publication:}

- A submitted manuscript is the version of the article upon submission and before peer-review. There can be important differences between the submitted version and the official published version of record.

People interested in the research are advised to contact the author for the final version of the publication, or visit the DOI to the publisher's website.

- The final author version and the galley proof are versions of the publication after peer review.

- The final published version features the final layout of the paper including the volume, issue and page numbers.

Link to publication

\footnotetext{
General rights rights.

- You may freely distribute the URL identifying the publication in the public portal. please follow below link for the End User Agreement:

www.umlib.nl/taverne-license

Take down policy

If you believe that this document breaches copyright please contact us at:

repository@maastrichtuniversity.nl

providing details and we will investigate your claim.
}

Copyright and moral rights for the publications made accessible in the public portal are retained by the authors and/or other copyright owners and it is a condition of accessing publications that users recognise and abide by the legal requirements associated with these

- Users may download and print one copy of any publication from the public portal for the purpose of private study or research.

- You may not further distribute the material or use it for any profit-making activity or commercial gain

If the publication is distributed under the terms of Article $25 \mathrm{fa}$ of the Dutch Copyright Act, indicated by the "Taverne" license above, 


\section{Statistische Bijlage \\ Schoolverlaters tussen onderwijs en arbeidsmarkt 2000}

ROA-R-2001/3B

Researchcentrum voor Onderwijs en Arbeidsmarkt

Faculteit der Economische Wetenschappen en Bedrijfskunde

Universiteit Maastricht

Maastricht, juni 2001 
Niets uit deze uitgave mag worden verveelvoudigd en/of openbaar gemaakt door middel van druk, fotokopie, microfilm, of op welke wijze ook, zonder voorafgaande schriftelijke toestemming van de directeur van het Researchcentrum voor Onderwijs en Arbeidsmarkt. In geval van overname van het datamateriaal moet telkens duidelijk als bron worden vermeld: "Researchcentrum voor Onderwijs en Arbeidsmarkt" of "ROA". Van publicaties waarin gebruik wordt gemaakt van gegevens uit deze Statistische Bijlage ontvangen wij gaarne een exemplaar.

Hoewel de grootst mogelijke zorg is besteed aan de inhoud van dit rapport, kan het ROA in generlei opzicht verantwoordelijkheid op zich nemen voor eventuele onvolledigheden of onjuistheden.

ISBN 90-5321-310-4

Sec01.144 


\section{Inhoud}

Bladzijde

Voorwoord

\section{A. Tabellen per opleidingssector}

\section{Bestemming van schoolverlaters}

A1.1 De uitstroom van schoolverlaters verbijzonderd naar geslacht, etniciteit en gemiddelde leeftijd op moment van enquête

A1.2 Vooropleiding van schoolverlaters

A1.3 Bestemming van schoolverlaters

A1.4 Gevolgde opleiding opnieuw kiezen?

\section{Doorstroom naar vervolgonderwijs}

A2.1 Doorstroom van schoolverlaters naar vervolgonderwijs

A2.2 Belangrijkste opleidingen van schoolverlaters die een voltijd vervolgopleiding zijn gaan volgen

A2.3 Oordeel van schoolverlaters over de aansluiting van de afgesloten opleiding met de voltijd vervolgopleiding

A2.4 Doorstroom van schoolverlaters naar de beroepsbegeleidende leerweg

3 Intrede op de arbeidsmarkt

A3.1 Werkloosheid en gemiddelde intredewerkloosheid van schoolverlaters die zich aanbieden op de arbeidsmarkt

A3.2 Aard van het dienstverband van werkende schoolverlaters

A3.3 Percentage werkende schoolverlaters met een flexibele aanstelling 28

A3.4 Wijze van verkrijgen van een baan 30

A3.5 Belangrijkste bedrijfsgroepen waarin schoolverlaters werkzaam zijn 32

A3.6 Belangrijkste beroepsgroepen waarin schoolverlaters werkzaam zijn 36

A3.7 Grootte van de organisatie waarin schoolverlaters werkzaam zijn 41

A3.8 Beloning van werkende schoolverlaters 43

A3.9 Vereist opleidingsniveau voor de huidige functie volgens de werkgever $\quad 45$

A3.10 Vereiste opleidingsrichting voor de huidige functie volgens de werkgever $\quad 46$

A3.11 Gewenste en feitelijke wekelijkse arbeidsduur van werkende schoolverlaters $\quad 48$

A3.12 Oordeel van de werkende schoolverlaters over de aansluiting tussen de afgesloten opleiding en de huidige functie

A3.13 Percentage werkende schoolverlaters dat op zoek is naar een andere baan

A3.14 Deelname aan een cursus of bedrijfsopleiding door werkende schoolverlaters

A3.15 Belangrijkste cursussen of bedrijfsopleidingen waaraan werkende schoolverlaters deelnemen

4 Kernindicatoren

A4.1 Enkele kernindicatoren 


\section{B. Tabellen per opleidingsrichting}

1 Bestemming van schoolverlaters

B1.1 De uitstroom van schoolverlaters verbijzonderd naar geslacht, etniciteit en gemiddelde leeftijd op moment van enquête

B1.2 Vooropleiding van schoolverlaters

B1.3 Bestemming van schoolverlaters

B1.4 Gevolgde opleiding opnieuw kiezen?

\section{Doorstroom naar vervolgonderwijs}

B2.1 Doorstroom van schoolverlaters naar vervolgonderwijs

B2.2 Belangrijkste opleidingen van schoolverlaters die een voltijd vervolgopleiding zijn gaan volgen

B2.3 Oordeel van schoolverlaters over de aansluiting van de afgesloten opleiding met de voltijd vervolgopleiding

B2.4 Doorstroom van schoolverlaters naar de beroepsbegeleidende leerweg

\section{Intrede op de arbeidsmarkt}

B3.1 Werkloosheid en gemiddelde intredewerkloosheid van schoolverlaters die zich aanbieden op de arbeidsmarkt

B3.2 Aard van het dienstverband van werkende schoolverlaters

B3.3 Percentage werkende schoolverlaters met een flexibele aanstelling 96

B3.4 Wijze van verkrijgen van een baan 98

B3.5 Belangrijkste bedrijfsgroepen waarin schoolverlaters werkzaam zijn 101

B3.6 Belangrijkste beroepsgroepen waarin schoolverlaters werkzaam zijn 110

B3.7 Grootte van de organisatie waarin schoolverlaters werkzaam zijn 119

B3.8 Beloning van werkende schoolverlaters 121

B3.9 Vereist opleidingsniveau voor de huidige functie volgens de werkgever 123

B3.10 Vereiste opleidingsrichting voor de huidige functie volgens de werkgever $\quad 125$

B3.11 Gewenste en feitelijke wekelijkse arbeidsduur van werkende schoolverlaters $\quad 127$

B3.12 Oordeel van de werkende schoolverlaters over de aansluiting tussen de afgesloten opleiding en de huidige functie

B3.13 Percentage werkende schoolverlaters dat op zoek is naar een andere baan

B3.14 Deelname aan een cursus of bedrijfsopleiding door werkende schoolverlaters

B3.15 Belangrijkste cursussen of bedrijfsopleidingen waaraan werkende schoolverlaters deelnemen

4 Kernindicatoren

B4.1 Enkele kernindicatoren 


\section{Respons}

C1 Ongewogen aantal respondenten verbijzonderd naar bestemming per opleidingssector

C2 Naar landelijke populatie gewogen aantal schoolverlaters verbijzonderd naar bestemming per opleidingssector

C3 Responspercentage per opleidingssector

C4 Ongewogen aantal respondenten verbijzonderd naar bestemming per opleidingsrichting

C5 Naar landelijke populatie gewogen aantal schoolverlaters verbijzonderd naar bestemming per opleidingsrichting

C6 Responspercentage per opleidingsrichting

\section{Opleidingsindeling}

Overzicht van opleidingen per opleidingssector 

Tabellenoverzicht Statistische Bijlage

Schoolverlaters tussen Onderwijs en Arbeidsmarkt

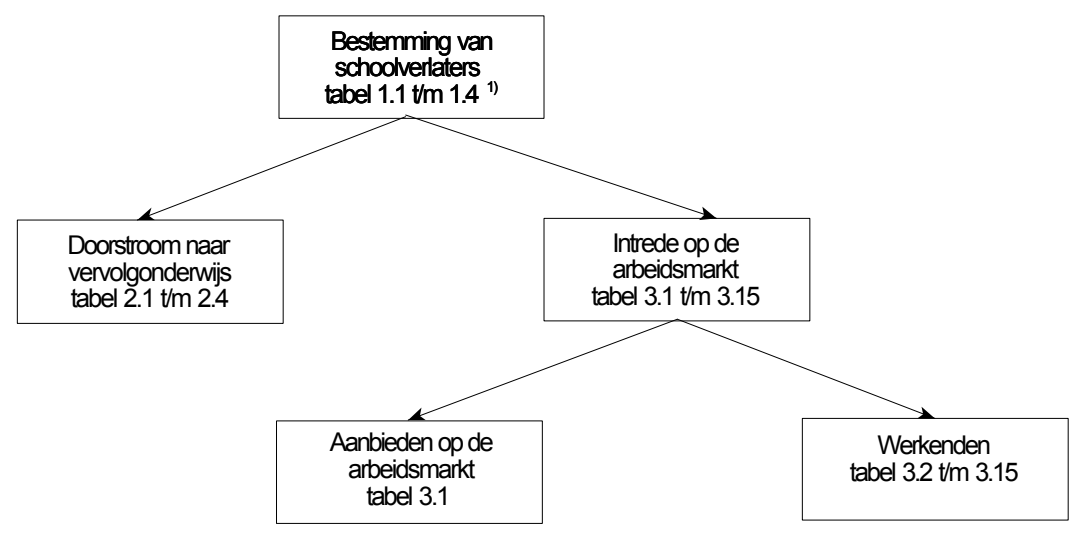

1) Tabelnummers gelden voor het A-deel en het B-deel van de statistische bijlage. Het A-deel bestaat uit tabellen naar opleidingssector, het B-deel uit tabellen naar opleidingsrichting. 



\section{Voorwoord}

In deze Statistische Bijlage bij het rapport Schoolverlaters tussen onderwijs en arbeidsmarkt 2000 wordt een overzicht gegeven van de belangrijkste resultaten van de schoolverlatersonderzoeken die door het Researchcentrum voor Onderwijs en Arbeidsmarkt (ROA) in het najaar van 2000 zijn gehouden onder schoolverlaters en afgestudeerden van het school- of studiejaar 1998/1999. De gegevens bestrijken de volle breedte van het Nederlandse onderwijssysteem en hebben betrekking op de situatie van schoolverlaters en afgestudeerden ongeveer anderhalf jaar na het voltooien van de opleiding. Allereerst betreft het de enquête Registratie van Uitstroom en Bestemming van Schoolverlaters (RUBS). Deze enquête is gericht op schoolverlaters van het algemeen voortgezet onderwijs (AVO), het voorbereidend beroepsonderwijs (VBO) en de beroepsopleidende (BOL) en beroepsbegeleidende leerweg (BBL) van het secundair beroepsonderwijs ${ }^{1}$. Daarnaast zijn gegevens opgenomen afkomstig uit de HBOMonitor en WO-Monitor. Dit zijn volledig vergelijkbare enquêtes gericht op afgestudeerden van het hoger onderwijs en ze worden uitgevoerd onder toezicht van respectievelijk de HBO-Raad en de Vereniging van Samenwerkende Nederlandse Universiteiten (VSNU).

Voor alle getoonde gegevens geldt dat het gaat om gediplomeerde schoolverlaters en afgestudeerden. Bovendien betreft het alleen de uitstroom van voltijdopleidingen. Een uitzondering hierop wordt gevormd door de gediplomeerde schoolverlaters van de BBL die leren en werken combineren.

In deel A worden de belangrijkste gegevens per onderwijssoort en opleidingssector (bijvoorbeeld BOL niveau 1/2 techniek, HBO economie, WO gezondheidszorg) gepresenteerd. Binnen het secundair beroepsonderwijs zijn daarbij de niveaus 1 en 2 (assistent beroepsbeoefenaar (AB) en beginnend beroepsbeoefenaar (BB)) aan de ene kant en de niveaus 3 en 4 (zelfstandig beroepsbeoefenaar (ZB) en (midden)kaderfunctionaris ((M)KF) of specialist) aan de andere kant samengenomen. Deel B geeft vervolgens voor de opleidingsrichtingen van VBO, BOL en BBL een gedetailleerder overzicht ${ }^{2}$. Daarbij worden alleen voor die opleidingsrichtingen cijfers gepresenteerd waarvoor de resultaten voldoende betrouwbaar worden geacht. Daartoe is een ondergrens van 15 respondenten gehanteerd. Bij tabellen die betrekking hebben op de beroepsbevolking of op werkenden is de ondergrens gesteld op 15 respondenten die tot de beroepsbevolking behoren. Bij tabellen die betrekking hebben op vervolgopleidingen of cursussen is de ondergrens gelegd bij minimaal 15 respondenten die een vervolgopleiding respectievelijk cursus hebben gevolgd. Overigens kunnen de gepresenteerde percentages bij sommige tabellen - vanwege ontbrekende waarnemingen - op een geringer aantal respondenten zijn gebaseerd. Hiermee dient bij de interpretatie van de gegevens rekening te worden gehouden.

Binnen de delen A en B is een onderverdeling gemaakt. Het eerste onderdeel van beide delen heeft betrekking op de bestemming van schoolverlaters: werken, leren of een combinatie van werken en leren via de BBL. Het tweede onderdeel gaat dieper in op degenen die verder leren, terwijl het derde onderdeel de intrede op de arbeidsmarkt nader beschrijft. De groep die werken

1. Een aantal van de hier onderzochte schoolverlaters heeft de opleiding nog in de oude kwalificatiestructuur gevolgd. Desondanks wordt in deze Statistische Bijlage voor iedere schoolverlater van een opleiding van het secundair beroepsonderwijs de naamgeving gebruikt zoals die geldt sinds de invoering van de Wet Educatie en Beroepsonderwijs (WEB).

2. Voor een gedetailleerd beeld van de resultaten voor het HBO wordt verwezen naar het onlangs verschenen Statistisch supplement van de HBO-Monitor 2000, uitgegeven door de HBO-Raad. Uitvoeriger resultaten van de WO-Monitor 2000 zullen later dit jaar bekend worden gemaakt door de VSNU. 
en leren combineert via de BBL komt zowel in het tweede onderdeel ('doorstroom naar vervolgonderwijs') als in het derde onderdeel ('intrede op de arbeidsmarkt') aan de orde. Ten slotte bevatten de delen $A$ en $B$ een samenvattende tabel met daarin de belangrijkste kernindicatoren.

Deel C geeft enkele achtergrondcijfers van de enquêtes: ongewogen en opgehoogde aantallen schoolverlaters, alsmede de responspercentages. In deel D is tot slot een overzicht opgenomen van de in de enquêtes opgenomen opleidingen per sector. 
A. Tabellen per opleidingssector 



\section{Inhoud}

1 Bestemming van schoolverlaters

A1.1 De uitstroom van schoolverlaters verbijzonderd naar geslacht, etniciteit en gemiddelde leeftijd op moment van enquête

A1.2 Vooropleiding van schoolverlaters

A1.3 Bestemming van schoolverlaters

A1.4 Gevolgde opleiding opnieuw kiezen?

\section{Doorstroom naar vervolgonderwijs}

A2.1 Doorstroom van schoolverlaters naar vervolgonderwijs

A2.2 Belangrijkste opleidingen van schoolverlaters die een voltijd vervolgopleiding zijn gaan volgen

A2.3 Oordeel van schoolverlaters over de aansluiting van de afgesloten opleiding met de voltijd vervolgopleiding

A2.4 Doorstroom van schoolverlaters naar de beroepsbegeleidende leerweg

3 Intrede op de arbeidsmarkt

A3.1 Werkloosheid en gemiddelde intredewerkloosheid van schoolverlaters die zich aanbieden op de arbeidsmarkt

A3.2 Aard van het dienstverband van werkende schoolverlaters

A3.3 Percentage werkende schoolverlaters met een flexibele aanstelling

A3.4 Wijze van verkrijgen van een baan

A3.5 Belangrijkste bedrijfsgroepen waarin schoolverlaters werkzaam zijn

A3.6 Belangrijkste beroepsgroepen waarin schoolverlaters werkzaam zijn

A3.7 Grootte van de organisatie waarin schoolverlaters werkzaam zijn

A3.8 Beloning van werkende schoolverlaters

A3.9 Vereist opleidingsniveau voor de huidige functie volgens de werkgever

A3.10 Vereiste opleidingsrichting voor de huidige functie volgens de werkgever

A3.11 Gewenste en feitelijke wekelijkse arbeidsduur van werkende schoolverlaters

A3.12 Oordeel van de werkende schoolverlaters over de aansluiting tussen de afgesloten opleiding en de huidige functie

A3.13 Percentage werkende schoolverlaters dat op zoek is naar een andere baan

A3.14 Deelname aan een cursus of bedrijfsopleiding door werkende schoolverlaters

A3.15 Belangrijkste cursussen of bedrijfsopleidingen waaraan werkende schoolverlaters deelnemen

\section{Kernindicatoren}

\section{A4.1 Enkele kernindicatoren}


Tabel A1.1

De uitstroom van schoolverlaters verbijzonderd naar geslacht, etniciteit en gemiddelde leeftijd op moment van enquête

\begin{tabular}{|c|c|c|c|}
\hline Opleidingssector & $\begin{array}{c}\text { vrouw } \\
\%\end{array}$ & $\begin{array}{c}\text { allochtoon } \\
\%\end{array}$ & $\begin{array}{r}\text { leeftijd } \\
\text { gem. }\end{array}$ \\
\hline AVO totaal & 53 & 7 & 18,2 \\
\hline MAVO & 52 & 7 & 17,3 \\
\hline HAVO & 55 & 6 & 18,7 \\
\hline VWO & 52 & 6 & 19,3 \\
\hline VBO totaal & 46 & 9 & 17,6 \\
\hline IVBO & 51 & 8 & 17,9 \\
\hline Landbouw & 52 & 3 & 17,4 \\
\hline Techniek & 6 & 6 & 17,6 \\
\hline Economie & 61 & 19 & 17,6 \\
\hline Gezondheidszorg & 94 & 7 & 17,4 \\
\hline BOL niveau $1 / 2$ totaal & 57 & 14 & 20,4 \\
\hline Landbouw & 51 & 0 & 20,0 \\
\hline Techniek & 5 & 11 & 20,3 \\
\hline Economie & 63 & 18 & 20,4 \\
\hline Gezondheidszorg & 94 & 8 & 20,8 \\
\hline BOL niveau $3 / 4$ totaal & 58 & 6 & 21,8 \\
\hline Landbouw & 43 & 1 & 21,3 \\
\hline Techniek & 15 & 4 & 22,5 \\
\hline Economie & 61 & 8 & 21,3 \\
\hline Gezondheidszorg & 89 & 6 & 21,3 \\
\hline Gedrag en maatschappij & 92 & 8 & 22,5 \\
\hline BBL niveau $1 / 2$ totaal & 28 & 8 & 22,9 \\
\hline Techniek & 3 & 6 & 22,7 \\
\hline Economie & 58 & 11 & 22,3 \\
\hline Gezondheidszorg & 98 & 13 & 25,7 \\
\hline BBL niveau $3 / 4$ totaal & 52 & 4 & 26,9 \\
\hline Techniek & 5 & 4 & 25,5 \\
\hline Economie & 40 & 2 & 23,6 \\
\hline Gezondheidszorg & 88 & 2 & 28,4 \\
\hline Gedrag en maatschappij & 98 & 20 & 32,7 \\
\hline HBO totaal & 54 & 6 & 24,9 \\
\hline Landbouw & 34 & 2 & 24,8 \\
\hline Onderwijs & 78 & 5 & 24,7 \\
\hline Techniek & 16 & 6 & 25,1 \\
\hline Economie & 49 & 6 & 24,7 \\
\hline Gezondheidszorg & 82 & 4 & 24,5 \\
\hline Gedrag en maatschappij & 83 & 6 & 24,7 \\
\hline Kunst en cultuur & 54 & 6 & 27,4 \\
\hline
\end{tabular}


Tabel A1.1 (vervolg)

De uitstroom van schoolverlaters verbijzonderd naar geslacht, etniciteit en gemiddelde leeftijd op moment van enquête

\begin{tabular}{lccr}
\hline Opleidingssector & $\begin{array}{c}\text { vrouw } \\
\%\end{array}$ & $\begin{array}{c}\text { allochtoon } \\
\%\end{array}$ & $\begin{array}{r}\text { leeftijd } \\
\text { gem. }\end{array}$ \\
\hline Wo totaal & & $\mathbf{7}$ & $\mathbf{2 7 , 1}$ \\
Landbouw & $\mathbf{5 3}$ & 4 & 25,8 \\
Techniek & 50 & 8 & 26,6 \\
Economie & 21 & 7 & 26,4 \\
Gezondheidszorg & 31 & 10 & 27,6 \\
Gedrag en maatschappij & 65 & 7 & 27,4 \\
Taal en culturr & 72 & 6 & 28,3 \\
Recht en openbare orde & 76 & 8 & 27,2 \\
Natuurwetenschappen & 59 & 7 & 25,8 \\
& 46 & $\mathbf{7}$ & $\mathbf{2 1 , 0}$ \\
Totaal & & & \\
& & &
\end{tabular}

\section{Toelichting}

- Om als allochtoon te worden aangemerkt, dient de afgestudeerde of tenminste één van zijn of haar ouders te zijn geboren in één van de landen die worden genoemd in de Wet SAMEN (Stimulering Arbeidsdeelname Minderheden).

- Het betreft de leeftijd per onderzoeksdatum ongeveer anderhalf jaar na schoolverlaten.

- Voor het WO zijn de resultaten met betrekking tot allochtonen gebaseerd op 9 universiteiten. 
Tabel A1.2

Vooropleiding van schoolverlaters

\begin{tabular}{|c|c|c|c|c|c|c|c|c|c|}
\hline Opleidingssector & MAVO & HAVO & VWO & VBO & $\begin{array}{r}\text { BOL } \\
\text { niv. } 1 / 2\end{array}$ & $\begin{array}{r}\mathrm{BOL} \\
\text { niv. } 3 / 4\end{array}$ & BBL & $\mathrm{HBO}$ & overig \\
\hline & $\%$ & $\%$ & $\%$ & $\%$ & $\%$ & $\%$ & $\%$ & $\%$ & $\%$ \\
\hline BOL niveau $1 / 2$ totaal & 24 & 1 & 0 & 67 & 4 & 2 & 1 & 0 & I \\
\hline Landbouw & 9 & 2 & 0 & 77 & 2 & 5 & 0 & 0 & 5 \\
\hline Techniek & 23 & 5 & 0 & 66 & 4 & 0 & 0 & 0 & 1 \\
\hline Economie & 27 & 0 & 0 & 64 & 5 & 2 & 0 & 0 & 1 \\
\hline Gezondheidszorg & 15 & 1 & 0 & 77 & 2 & 2 & 3 & 0 & 0 \\
\hline BOL niveau $3 / 4$ totaal & 58 & 13 & 0 & 20 & 3 & 4 & 0 & 0 & 0 \\
\hline Landbouw & 47 & 9 & 0 & 38 & 1 & 4 & 0 & 0 & 0 \\
\hline Techniek & 54 & 14 & 1 & 24 & 3 & 4 & 1 & 0 & 0 \\
\hline Economie & 64 & 21 & 0 & 8 & 4 & 1 & 0 & 0 & 0 \\
\hline Gezondheidszorg & 57 & 7 & 0 & 27 & 3 & 4 & 1 & 0 & 0 \\
\hline Gedrag en maatschappij & 61 & 6 & 0 & 23 & 2 & 6 & 0 & 0 & 0 \\
\hline BBL niveau $1 / 2$ totaal & 21 & 4 & 1 & 58 & 5 & 7 & 3 & 1 & 0 \\
\hline Techniek & 14 & 5 & 0 & 69 & 6 & 4 & 2 & 0 & 1 \\
\hline Economie & 30 & 2 & 2 & 44 & 5 & 12 & 4 & 1 & 0 \\
\hline Gezondheidszorg & 32 & 10 & 0 & 39 & 2 & 11 & 4 & 1 & 0 \\
\hline BBL niveau $3 / 4$ totaal & 25 & 7 & 2 & 24 & 6 & 21 & 11 & 3 & 1 \\
\hline Techniek & 19 & 1 & 1 & 38 & 9 & 14 & 18 & 0 & 0 \\
\hline Economie & 34 & 5 & 3 & 27 & 13 & 13 & 5 & 0 & 1 \\
\hline Gezondheidszorg & 24 & 14 & 3 & 8 & 1 & 32 & 9 & 7 & 2 \\
\hline Gedrag en maatschappij & 30 & 5 & 0 & 40 & 2 & 15 & 0 & 2 & 5 \\
\hline
\end{tabular}


Tabel A1.2 (vervolg)

Vooropleiding van schoolverlaters

\begin{tabular}{|c|c|c|c|c|c|c|c|c|c|}
\hline \multirow[t]{2}{*}{ Opleidingssector } & MAVO & HAVO & VWO & VBO & $\begin{array}{r}\mathrm{BOL} \\
\text { niv. } 1 / 2\end{array}$ & $\begin{array}{r}\mathrm{BOL} \\
\text { niv. } 3 / 4\end{array}$ & BBL & $\mathrm{HBO}$ & overig \\
\hline & $\%$ & $\%$ & $\%$ & $\%$ & $\%$ & $\%$ & $\%$ & $\%$ & $\%$ \\
\hline HBO totaal & 1 & 45 & 27 & 0 & 0 & 26 & 0 & 1 & 0 \\
\hline Landbouw & 0 & 48 & 17 & 0 & 0 & 34 & 0 & 0 & 0 \\
\hline Onderwijs & 1 & 65 & 15 & 0 & 0 & 17 & 0 & 1 & 1 \\
\hline Techniek & 1 & 35 & 28 & 0 & 0 & 34 & 0 & 1 & 0 \\
\hline Economie & 0 & 36 & 38 & 0 & 0 & 25 & 0 & 0 & 0 \\
\hline Gezondheidszorg & 1 & 55 & 27 & 0 & 0 & 16 & 0 & 1 & 1 \\
\hline Gedrag en maatschappij & 1 & 50 & 17 & 0 & 0 & 31 & 0 & 1 & 0 \\
\hline Kunst en cultuur & 5 & 39 & 32 & 0 & 0 & 16 & 0 & 5 & 2 \\
\hline WO totaal & 0 & 1 & 84 & 0 & 0 & 0 & 0 & 14 & 0 \\
\hline Landbouw & 0 & 1 & 83 & 0 & 0 & 0 & 0 & 16 & 0 \\
\hline Techniek & 0 & 0 & 91 & 0 & 0 & 0 & 0 & 9 & 0 \\
\hline Economie & 0 & 0 & 80 & 0 & 0 & 0 & 0 & 19 & 0 \\
\hline Gezondheidszorg & 0 & 1 & 92 & 0 & 0 & 0 & 0 & 7 & 0 \\
\hline Gedrag en maatschappij & 0 & 1 & 76 & 0 & 0 & 0 & 0 & 22 & 0 \\
\hline Taal en cultuur & 0 & 3 & 81 & 0 & 0 & 0 & 0 & 15 & 0 \\
\hline Recht en openbare orde & 0 & 2 & 87 & 0 & 0 & 1 & 0 & 10 & 0 \\
\hline Natuurwetenschappen & 0 & 0 & 91 & 0 & 0 & 0 & 0 & 8 & 0 \\
\hline Totaal & 23 & 19 & 21 & 19 & 2 & 12 & 1 & 3 & 0 \\
\hline
\end{tabular}


Tabel A1.3

Bestemming van schoolverlaters

\begin{tabular}{|c|c|c|c|c|c|}
\hline \multirow[t]{2}{*}{ Opleidingssector } & \multirow{2}{*}{$\begin{array}{r}\text { studie } \\
\\
\%\end{array}$} & \multirow{2}{*}{$\begin{array}{r}\text { BBL } \\
\\
\%\end{array}$} & \multirow{2}{*}{$\begin{array}{r}\text { betaald } \\
\text { werk } \\
\% \\
\end{array}$} & \multirow{2}{*}{$\begin{array}{r}\text { werkloos } \\
\%\end{array}$} & \multirow{2}{*}{$\begin{array}{r}\text { anders } \\
\% \\
\end{array}$} \\
\hline & & & & & \\
\hline AVO totaal & 85 & 4 & 9 & 0 & 2 \\
\hline MAVO & 78 & 8 & 11 & 0 & 3 \\
\hline HAVO & 86 & 2 & 10 & 0 & 2 \\
\hline VWO & 94 & 0 & 4 & 0 & 1 \\
\hline VBO totaal & 51 & 18 & 27 & 1 & 3 \\
\hline IVBO & 40 & 22 & 29 & 1 & 9 \\
\hline Landbouw & 65 & 15 & 17 & 1 & 2 \\
\hline Techniek & 36 & 23 & 37 & 1 & 3 \\
\hline Economie & 64 & 9 & 21 & 2 & 3 \\
\hline Gezondheidszorg & 66 & 15 & 18 & 0 & 1 \\
\hline BOL niveau $1 / 2$ totaal & 21 & 10 & 65 & 2 & 2 \\
\hline Landbouw & 11 & 8 & 76 & 5 & 0 \\
\hline Techniek & 16 & 17 & 66 & 0 & 1 \\
\hline Economie & 22 & 6 & 67 & 2 & 2 \\
\hline Gezondheidszorg & 23 & 18 & 55 & 2 & 2 \\
\hline BOL niveau $3 / 4$ totaal & 36 & 3 & 58 & 1 & 2 \\
\hline Landbouw & 25 & 2 & 71 & 1 & 2 \\
\hline Techniek & 39 & 1 & 58 & 1 & 2 \\
\hline Economie & 40 & 2 & 56 & 1 & 2 \\
\hline Gezondheidszorg & 26 & 8 & 62 & 1 & 3 \\
\hline Gedrag en maatschappij & 39 & 3 & 55 & 1 & 2 \\
\hline BBL niveau $1 / 2$ totaal & 2 & 18 & 78 & 0 & 2 \\
\hline Techniek & 1 & 16 & 81 & 0 & 1 \\
\hline Economie & 3 & 26 & 67 & 1 & 3 \\
\hline Gezondheidszorg & 4 & 2 & 90 & 2 & 2 \\
\hline BBL niveau $3 / 4$ totaal & 3 & 2 & 92 & 1 & 3 \\
\hline Techniek & 3 & 2 & 94 & 0 & 1 \\
\hline Economie & 4 & 4 & 89 & 2 & 2 \\
\hline Gezondheidszorg & 2 & 2 & 91 & 1 & 4 \\
\hline Gedrag en maatschappij & 2 & 4 & 92 & 0 & 3 \\
\hline HBO totaal & 14 & $\mathbf{x}$ & 83 & 2 & 1 \\
\hline Landbouw & 13 & $x$ & 84 & 2 & 1 \\
\hline Onderwijs & 9 & $x$ & 88 & 2 & 1 \\
\hline Techniek & 16 & $x$ & 81 & 2 & 1 \\
\hline Economie & 16 & $x$ & 81 & 2 & 1 \\
\hline Gezondheidszorg & 10 & $x$ & 86 & 2 & 1 \\
\hline Gedrag en maatschappij & 13 & $x$ & 83 & 2 & 2 \\
\hline Kunst en cultuur & 12 & $x$ & 77 & 2 & 9 \\
\hline
\end{tabular}


Tabel A1.3 (vervolg)

Bestemming van schoolverlaters

\begin{tabular}{lccccc} 
Opleidingssector & studie & BBL & $\begin{array}{r}\text { betaald } \\
\text { werk }\end{array}$ & werkloos & anders \\
& $\%$ & $\%$ & $\%$ & $\%$ & $\%$ \\
\hline Wo totaal & $\mathbf{4}$ & $\mathbf{x}$ & $\mathbf{9 1}$ & $\mathbf{2}$ & $\mathbf{3}$ \\
Landbouw & 4 & $\mathrm{x}$ & 89 & 5 & 3 \\
Techniek & 3 & $\mathrm{x}$ & 95 & 1 & 1 \\
Economie & 2 & $\mathrm{x}$ & 95 & 2 & 1 \\
Gezondheidszorg & 8 & $\mathrm{x}$ & 86 & 1 & 5 \\
Gedrag en maatschappij & 3 & $\mathrm{x}$ & 91 & 3 & 4 \\
Taal en cultuur & 6 & $\mathrm{x}$ & 85 & 4 & 5 \\
Recht en openbare orde & 2 & $\mathrm{x}$ & 95 & 2 & 1 \\
Natuurwetenschappen & 7 & $\mathrm{x}$ & 89 & 2 & 2 \\
& & & & & \\
Totaal & $\mathbf{4 6}$ & $\mathbf{6}$ & $\mathbf{4 5}$ & $\mathbf{1}$ & $\mathbf{2}$ \\
\hline
\end{tabular}

$\mathrm{x}=$ antwoordcategorie niet opgenomen 
Tabel A1.4

Gevolgde opleiding opnieuw kiezen?

\begin{tabular}{|c|c|c|c|}
\hline Opleidingssector & $\begin{array}{r}\text { zelfde } \\
\text { opleiding }\end{array}$ & $\begin{array}{r}\text { andere } \\
\text { opleiding }\end{array}$ & $\begin{array}{r}\text { geen andere } \\
\text { opleiding }\end{array}$ \\
\hline & $\%$ & $\%$ & $\%$ \\
\hline BOL niveau $1 / 2$ totaal & 70 & 23 & 7 \\
\hline Landbouw & 76 & 15 & 8 \\
\hline Techniek & 71 & 25 & 4 \\
\hline Economie & 68 & 25 & 7 \\
\hline Gezondheidszorg & 75 & 18 & 8 \\
\hline BOL niveau $3 / 4$ totaal & 81 & 18 & 1 \\
\hline Landbouw & 84 & 15 & 1 \\
\hline Techniek & 84 & 15 & 1 \\
\hline Economie & 76 & 24 & 1 \\
\hline Gezondheidszorg & 77 & 21 & 2 \\
\hline Gedrag en maatschappij & 86 & 13 & 1 \\
\hline BBL niveau $1 / 2$ totaal & 75 & 17 & 8 \\
\hline Techniek & 80 & 12 & 7 \\
\hline Economie & 66 & 25 & 9 \\
\hline Gezondheidszorg & 72 & 26 & 2 \\
\hline BBL $3 / 4$ totaal & 82 & 15 & 3 \\
\hline Techniek & 86 & 10 & 3 \\
\hline Economie & 73 & 24 & 3 \\
\hline Gezondheidszorg & 83 & 16 & 1 \\
\hline Gedrag en maatschappij & 85 & 9 & 7 \\
\hline HBO totaal & 77 & 22 & 1 \\
\hline Landbouw & 77 & 23 & 0 \\
\hline Onderwijs & 83 & 16 & 0 \\
\hline Techniek & 79 & 21 & 1 \\
\hline Economie & 73 & 26 & 1 \\
\hline Gezondheidszorg & 80 & 20 & 0 \\
\hline Gedrag en maatschappij & 72 & 27 & 0 \\
\hline Kunst en cultuur & 87 & 11 & 2 \\
\hline WO totaal & 82 & 18 & 0 \\
\hline Landbouw & 75 & 24 & 1 \\
\hline Techniek & 85 & 15 & 0 \\
\hline Economie & 86 & 14 & 0 \\
\hline Gezondheidszorg & 83 & 17 & 0 \\
\hline Gedrag en maatschappij & 79 & 21 & 1 \\
\hline Taal en cultuur & 77 & 23 & 1 \\
\hline Recht en openbare orde & 85 & 15 & 0 \\
\hline Natuurwetenschappen & 80 & 20 & 0 \\
\hline Totaal & 79 & 19 & 2 \\
\hline
\end{tabular}

Toelichting

- Voor het WO hebben de resultaten betrekking op 10 universiteiten. 
Tabel A2. 1

Doorstroom van schoolverlaters naar vervolgonderwijs

\begin{tabular}{|c|c|c|c|c|c|c|c|c|c|c|c|c|c|}
\hline \multirow[t]{2}{*}{ Opleidingssector } & $\begin{array}{r}\text { verder } \\
\text { leren }\end{array}$ & MAVO & HAVO & VWO & VBO & $\begin{array}{r}\mathrm{BOL} \\
\text { niv. } 1 / 2\end{array}$ & $\begin{array}{r}\text { BOL } \\
\text { niv. } 3 / 4\end{array}$ & $\begin{array}{r}\text { BBL } \\
\text { niv. } 1 / 2\end{array}$ & $\begin{array}{r}\text { BBL } \\
\text { niv. } 3 / 4\end{array}$ & $\mathrm{HBO}$ & $\begin{array}{c}\text { post } \\
\text { HBO }\end{array}$ & wo & $\begin{array}{l}\text { post } \\
\text { WO }\end{array}$ \\
\hline & $\%$ & $\%$ & $\%$ & $\%$ & $\%$ & $\%$ & $\%$ & $\%$ & $\%$ & $\%$ & $\%$ & $\%$ & $\%$ \\
\hline AVO totaal & 97 & 0 & 4 & 1 & 0 & 6 & 33 & 1 & 2 & 35 & 0 & 18 & 0 \\
\hline MAVO & 97 & 0 & 8 & 0 & 0 & 12 & 72 & 2 & 4 & 1 & 0 & 0 & 0 \\
\hline HAVO & 96 & 0 & 1 & 3 & 0 & 2 & 11 & 0 & 1 & 82 & 0 & 0 & 0 \\
\hline VWO & 97 & 0 & 0 & 1 & 0 & 0 & 0 & 0 & 0 & 31 & 0 & 68 & 0 \\
\hline VBO totaal & 90 & 1 & 0 & 0 & 0 & 20 & 54 & 16 & 8 & 0 & 0 & 0 & 0 \\
\hline IVBO & 82 & 0 & 0 & 0 & 1 & 51 & 22 & 19 & 7 & 0 & 0 & 0 & 0 \\
\hline Landbouw & 92 & 1 & 0 & 0 & 0 & 16 & 69 & 9 & 4 & 0 & 0 & 0 & 0 \\
\hline Techniek & 88 & 1 & 0 & 0 & 0 & 9 & 49 & 30 & 10 & 0 & 0 & 0 & 0 \\
\hline Economie & 91 & 1 & 0 & 0 & 0 & 25 & 65 & 7 & 3 & 0 & 0 & 0 & 0 \\
\hline Gezondheidszorg & 94 & 1 & 0 & 0 & 0 & 19 & 60 & 8 & 12 & 0 & 0 & 0 & 0 \\
\hline BOL niveau $1 / 2$ totaal & 47 & 1 & 0 & $\mathbf{0}$ & 0 & 9 & 57 & 15 & 15 & 2 & 0 & $\mathbf{0}$ & 0 \\
\hline Landbouw & 25 & 0 & 0 & 0 & 0 & 8 & 57 & 20 & 15 & 0 & 0 & 0 & 0 \\
\hline Techniek & 54 & 0 & 0 & 0 & 0 & 13 & 52 & 8 & 21 & 6 & 0 & 0 & 0 \\
\hline Economie & 41 & 2 & 0 & 0 & 0 & 10 & 59 & 14 & 12 & 2 & 0 & 0 & 0 \\
\hline Gezondheidszorg & 65 & 0 & 0 & 0 & 0 & 6 & 55 & 20 & 19 & 0 & 0 & 0 & 0 \\
\hline BOL niveau $3 / 4$ totaal & 49 & 0 & 0 & 0 & 0 & 1 & 8 & 1 & 4 & 86 & 0 & 0 & 0 \\
\hline Landbouw & 33 & 0 & 1 & 0 & 0 & 5 & 13 & 1 & 7 & 71 & 0 & 1 & 0 \\
\hline Techniek & 47 & 0 & 0 & 0 & 0 & 1 & 6 & 0 & 1 & 92 & 0 & 0 & 0 \\
\hline Economie & 52 & 0 & 0 & 0 & 0 & 0 & 4 & 0 & 1 & 93 & 0 & 0 & 1 \\
\hline Gezondheidszorg & 48 & 0 & 0 & 0 & 0 & 1 & 25 & 2 & 17 & 55 & 0 & 0 & 0 \\
\hline Gedrag en maatschappij & 53 & 0 & 0 & 0 & 0 & 0 & 4 & 0 & 3 & 92 & 0 & 0 & 0 \\
\hline
\end{tabular}


Tabel A2. 1 (vervolg)

Doorstroom van schoolverlaters naar vervolgonderwijs

\begin{tabular}{|c|c|c|c|c|c|c|c|c|c|c|c|c|c|}
\hline \multirow[t]{2}{*}{ Opleidingssector } & $\begin{array}{r}\text { verder } \\
\text { leren }\end{array}$ & MAVO & HAVO & VWO & VBO & $\begin{array}{r}\text { BOL } \\
\text { niv. } 1 / 2\end{array}$ & $\begin{array}{r}\text { BOL } \\
\text { niv. } 3 / 4\end{array}$ & $\begin{array}{r}\text { BBL } \\
\text { niv. } 1 / 2\end{array}$ & $\begin{array}{r}\text { BBL } \\
\text { niv. } 3 / 4\end{array}$ & $\mathrm{HBO}$ & $\begin{array}{c}\text { post } \\
\text { HBO }\end{array}$ & WO & $\begin{array}{l}\text { post } \\
\text { WO }\end{array}$ \\
\hline & $\%$ & $\%$ & $\%$ & $\%$ & $\%$ & $\%$ & $\%$ & $\%$ & $\%$ & $\%$ & $\%$ & $\%$ & $\%$ \\
\hline BBL niveau $1 / 2$ totaal & 43 & 0 & 0 & 0 & 0 & 5 & 12 & 22 & 60 & 1 & 0 & 0 & 0 \\
\hline Techniek & 42 & 0 & 0 & 0 & 0 & 3 & 8 & 21 & 66 & 2 & 0 & 0 & 0 \\
\hline Economie & 51 & 0 & 0 & 0 & 0 & 10 & 19 & 23 & 49 & 0 & 0 & 0 & 0 \\
\hline Gezondheidszorg & 22 & 0 & 0 & 0 & 0 & 0 & 19 & 20 & 61 & 0 & 0 & 0 & 0 \\
\hline BBL niveau $3 / 4$ totaal & 21 & 0 & 0 & 0 & 0 & 2 & 19 & 5 & 43 & 31 & 0 & 0 & 0 \\
\hline Techniek & 30 & 0 & 1 & 0 & 0 & 5 & 32 & 5 & 47 & 11 & 0 & 0 & 0 \\
\hline Economie & 24 & 0 & 0 & 0 & 0 & 0 & 16 & 16 & 48 & 20 & 0 & 0 & 0 \\
\hline Gezondheidszorg & 14 & 0 & 0 & 0 & 0 & 0 & 0 & 0 & 37 & 63 & 0 & 0 & 0 \\
\hline Gedrag en maatschappij & 9 & 0 & 0 & 0 & 0 & 0 & 29 & 0 & 32 & 40 & 0 & 0 & 0 \\
\hline HBO totaal & 27 & 0 & 0 & 0 & 0 & 0 & 0 & 0 & 3 & 28 & 1 & 65 & 3 \\
\hline Landbouw & 26 & 0 & 0 & 0 & 0 & 0 & 1 & 0 & 14 & 23 & 9 & 51 & 2 \\
\hline Onderwijs & 28 & 0 & 0 & 0 & 0 & 0 & 1 & 0 & 1 & 63 & 0 & 35 & 0 \\
\hline Techniek & 27 & 0 & 0 & 0 & 0 & 0 & 0 & 0 & 3 & 24 & 1 & 70 & 2 \\
\hline Economie & 29 & 0 & 0 & 0 & 0 & 0 & 0 & 0 & 2 & 14 & 0 & 77 & 6 \\
\hline Gezondheidszorg & 23 & 0 & 0 & 0 & 0 & 0 & 0 & 0 & 7 & 25 & 1 & 66 & 1 \\
\hline Gedrag en maatschappij & 24 & 0 & 0 & 0 & 0 & 0 & 0 & 0 & 1 & 26 & 0 & 71 & 1 \\
\hline Kunst en cultuur & 21 & 0 & 0 & 0 & 0 & 0 & 2 & 0 & 4 & 47 & 22 & 25 & 1 \\
\hline
\end{tabular}


Tabel A2. 1 (vervolg)

Doorstroom van schoolverlaters naar vervolgonderwijs

\begin{tabular}{|c|c|c|c|c|c|c|c|c|c|c|c|c|c|}
\hline Opleidingssector & $\begin{array}{r}\text { verder } \\
\text { leren }\end{array}$ & MAVO & HAVO & VWO & VBO & $\begin{array}{r}\text { BOL } \\
\text { niv. } 1 / 2\end{array}$ & $\begin{array}{r}\text { BOL } \\
\text { niv. } 3 / 4\end{array}$ & $\begin{array}{r}\text { BBL } \\
\text { niv. } 1 / 2\end{array}$ & $\begin{array}{r}\text { BBL } \\
\text { niv. } 3 / 4\end{array}$ & $\mathrm{HBO}$ & $\begin{array}{l}\text { post } \\
\text { HBO }\end{array}$ & Wo & $\begin{array}{l}\text { post } \\
\text { WO }\end{array}$ \\
\hline & $\%$ & $\%$ & $\%$ & $\%$ & $\%$ & $\%$ & $\%$ & $\%$ & $\%$ & $\%$ & $\%$ & $\%$ & $\%$ \\
\hline WO totaal & 26 & 0 & 0 & 0 & 0 & 0 & 0 & 0 & 0 & 4 & 0 & 23 & 72 \\
\hline Landbouw & 22 & 0 & 0 & 0 & 0 & 0 & 0 & 0 & 0 & 0 & 0 & 9 & 89 \\
\hline Techniek & 18 & 0 & 0 & 0 & 0 & 0 & 0 & 0 & 0 & 3 & 0 & 18 & 79 \\
\hline Economie & 24 & 0 & 0 & 0 & 0 & 0 & 0 & 0 & 0 & 3 & 0 & 17 & 79 \\
\hline Gezondheidszorg & 37 & 0 & 0 & 0 & 0 & 0 & 0 & 0 & 0 & 2 & 0 & 13 & 85 \\
\hline Gedrag en maatschappij & 18 & 0 & 0 & 0 & 0 & 0 & 0 & 0 & 0 & 8 & 0 & 25 & 67 \\
\hline Taal en cultuur & 27 & 0 & 0 & 0 & 0 & 0 & 0 & 0 & 0 & 9 & 0 & 56 & 35 \\
\hline Recht en openbare orde & 21 & 0 & 0 & 0 & 0 & 0 & 0 & 0 & 1 & 3 & 1 & 23 & 72 \\
\hline Natuurwetenschappen & 50 & 0 & 0 & 0 & 0 & 0 & 0 & 0 & 0 & 2 & 0 & 20 & 78 \\
\hline Totaal & 65 & 0 & 2 & 1 & 0 & 7 & 31 & 4 & 5 & 32 & 0 & 15 & 2 \\
\hline
\end{tabular}


Tabel A2.2

Belangrijkste opleidingen van schoolverlaters die een voltijd vervolgopleiding zijn gaan volgen

MAVO

HAVO

HAVO

HBO Leraar basisonderwijs

VWO

WO Nederlands recht

IVBO

BOL BB Helpende (verpleging en verzorging)

VBO landbouw

BOL KF Veehouderij

VBO techniek

BOL MKF Bouwkunde

VBO economie

BOL MKF Bedrijfsadministratief

VBO gezondheidszorg

BOL MKF Sociaal-pedagogisch werk

$B O L$ BB Helpende (verpleging en verzorging)

BOL ZB Verzorgende

BOL niveau 1/2 landbouw

BBL ZB Machinist grondverzetmachines 12

BOL ZB Akkerbouw 10

BOL ZB Bloemschikken $\quad 10$

BOL ZB Groenvoorziening

BBL AB Landbouw 10

BOL KF Bloemschikken

$\begin{array}{ll}\text { BBL BB Bloemschikken } & 7\end{array}$

BOL ZB Machinist gww 6

BOL niveau $1 / 2$ techniek

BBL MKF Techniek

BOL BB Autotechnicus

BOL niveau 1/2 economie

BOL MKF Economie

BOL MKF Detailhandel/ambulante handel 
Tabel A2.2 (vervolg)

Belangrijkste opleidingen van schoolverlaters die een voltijd vervolgopleiding zijn gaan volgen

BOL niveau $1 / 2$ gezondheidszorg

BOL MKF Verzorgende

BOL MKF Sociaal-pedagogisch werk

BOL ZB Verzorgende

$B B L B B$ Verpleging en verzorging

BBL ZB Verzorgende

BOL MKF Facilitaire dienstverlening

BOL niveau 3/4 landbouw

HBO Veehouderij

HBO Landbouw

HBO Tuin- en landschapsinrichting

HBO Agrarische bedrijfskunde

HBO Levensmiddelentechnologie

BOL niveau 3/4 techniek

HBO Bouwkunde

HBO Werktuigbouwkunde

HBO Elektrotechniek

BOL niveau 3/4 economie

HBO Bedrijfseconomie

HBO Commerciele economie

HBO Management, economie en recht

BOL niveau $3 / 4$ gezondheidszorg

HBO Opleiding tot verpleegkundige

BOL MKF Verpleegkundige

BBL MKF Verpleegkundige

BOL niveau 3/4 gedrag en maatschappij

HBO Sociaal pedagogische hulpverlening

HBO Leraar basisonderwijs

HBO Maatschappelijk werk en dienstverlening

HBO Personeel en arbeid

$B B L$ niveau $1 / 2$ techniek

BBL ZB Voortgezette timmerkracht

BBL ZB Gezel schilder

$B B L$ niveau $1 / 2$ economie

BBL ZB Zelfstandig werkend kok 13

BBL ZB Eerste verkoper $\quad 12$

BBL BB Kok 9

BBL ZB Zelfstandig werkend gastheer/-vrouw $\quad 9$

BBL niveau $1 / 2$ gezondheidszorg

BBL MKF Verpleegkundige

BBL BB Voedingsassistent

BOL MKF Verpleegkundige 
Tabel A2.2 (vervolg)

Belangrijkste opleidingen van schoolverlaters die een voltijd vervolgopleiding zijn gaan volgen

BBL niveau 3/4 techniek

BBL MKF Assistent-uitvoerder B\&U

HBO Leraar basisonderwijs

BOL MKF Detailhandel/ambulante handel

BOL Specialist Technicus sterkstroominstallaties

BBL niveau 3/4 economie

BBL MKF Verpleegkundige

BBL BB Kok

BBL ZB Verkoopchef

BBL Specialist Gespecialiseerd kok

HBO Kort Marketing management

BOL MKF Ondernemer kleinbedrijf textielindustrie en -handel

BBL BB Gastheer/-vrouw

BBL ZB Slagerij en vleessector

BBL MKF Ondernemer/manager detailhandel

BOL MKF Systeembeheerder MKB

HBO Hogere opleiding system engineer

HBO Bedrijfskundige informatica

BBL niveau $3 / 4$ gezondheidszorg

HBO Sociaal pedagogische hulpverlening $\quad 22$

In-service Ziekenverzorgende 18

BBL ZB Verzorgende bij inst. voor gezinsverz.

HBO Opleiding tot verpleegkundige 11

HBO Operatie-assistent anesthesie 11

HBO Personeelsmanagement 11

BBL ZB Sociaal-pedagogisch werk 1

$\begin{array}{ll}\text { HBO Marketing } & 7\end{array}$

BBL niveau 3/4 gedrag en maatschappij

BBL MKF Verpleegkundige

HBO Maatschappelijk werk en dienstverlening

BOL MKF Sociaal-pedagogisch werk $\quad 29$

HBO Sociaal-juridische dienstverlening 7

HBO landbouw

HBO Master's opleiding Landbouw

HBO onderwijs

HBO Leraar speciaal onderwijs

WO Pedagogische wetenschappen $\quad 12$

HBO techniek

WO Bouwkunde

HBO Technische bedrijfskunde $\quad 8$

WO Bedrijfskunde $\quad 8$

HBO economie

WO Bedrijfskunde

WO Bedrijfseconomie $\quad 9$

WO Bedrijfskunde

WO Nederlands recht $\quad 6$ 
Tabel A2.2 (vervolg)

Belangrijkste opleidingen van schoolverlaters die een voltijd vervolgopleiding zijn gaan volgen

HBO gezondheidszorg

WO Gezondheidswetenschappen

WO Pedagogische wetenschappen

HBO Master's opleiding Gezondheidszorg

WO Bewegingswetenschappen

WO Psychologie

HBO gedrag en maatschappij

WO Pedagogische wetenschappen

WO Nederlands recht

WO Psychologie

WO Sociaal-culturele wetenschappen

WO Beleids- en organisatiewetenschappen

HBO kunst en cultuur

$\mathrm{HBO} 2 \mathrm{e}$ fase Aantekening kamermuziek

WO landbouw

$\mathrm{AIO} / \mathrm{OIO}$

Post-doctorale beroepsopleiding

WO Diergeneeskunde

WO techniek

AIO/OIO

Ontwerpersopleiding

Post-doctorale beroepsopleiding

WO economie

Post-doctorale beroepsopleiding

Post-doct. beroepsopl. Accountant

AIO/OIO

WO Nederlands recht

WO gezondheidszorg

$\mathrm{AIO} / \mathrm{OIO}$

Post-doctorale beroepsopleiding

Post-doct. beroepsopl. Medisch specialist (AGIO)

WO Geneeskunde

WO gedrag en maatschappij

$\mathrm{AlO} / \mathrm{OIO}$

Post-doctorale beroepsopleiding

WO Kort Onderwijs

WO taal en cultuur

WO Kort Onderwijs

$\mathrm{AlO} / \mathrm{OIO}$

Post-doctorale beroepsopleiding 
Tabel A2.2 (vervolg)

Belangrijkste opleidingen van schoolverlaters die een voltijd vervolgopleiding zijn gaan volgen

WO recht en openbare orde

Post-doctorale beroepsopleiding

Post-doct. beroepsopl. Advocatuur

AIO/OIO

Post-doct. beroepsopl. Kandidaat notaris opleiding

WO natuurwetenschappen

$\mathrm{AIO} / \mathrm{OIO}$

WO Kort Onderwijs

\section{Toelichting}

- In de tabel zijn alleen die opleidingen opgenomen die door ten minste 5\% van de schoolverlaters worden gevolgd. 
Tabel A2.3

Oordeel van schoolverlaters over de aansluiting van de afgesloten opleiding met de voltijd vervolgopleiding

\begin{tabular}{|c|c|c|c|c|}
\hline Opleidingssector & $\begin{array}{r}\text { goed } \\
\% \\
\end{array}$ & $\begin{array}{r}\text { voldoende } \\
\% \\
\end{array}$ & $\begin{array}{r}\text { matig } \\
\%\end{array}$ & $\begin{array}{r}\text { slecht } \\
\% \\
\end{array}$ \\
\hline AVO totaal & 30 & 43 & 20 & 7 \\
\hline MAVO & 28 & 44 & 20 & 8 \\
\hline HAVO & 28 & 40 & 26 & 7 \\
\hline VWO & 38 & 46 & 13 & 3 \\
\hline VBO totaal & 32 & 39 & 20 & 9 \\
\hline IVBO & 28 & 36 & 21 & 15 \\
\hline Techniek & 34 & 40 & 18 & 8 \\
\hline Economie & 28 & 38 & 23 & 10 \\
\hline Gezondheidszorg & 32 & 37 & 21 & 10 \\
\hline BOL niveau $1 / 2$ totaal & 50 & 34 & 9 & 6 \\
\hline Landbouw & 36 & 28 & 28 & 9 \\
\hline Techniek & 62 & 33 & 5 & 0 \\
\hline Economie & 45 & 37 & 8 & 10 \\
\hline Gezondheidszorg & 53 & 29 & 15 & 3 \\
\hline BOL niveau $3 / 4$ totaal & 34 & 40 & 18 & 7 \\
\hline Landbouw & 31 & 41 & 19 & 9 \\
\hline Techniek & 37 & 42 & 15 & 7 \\
\hline Economie & 32 & 40 & 20 & 8 \\
\hline Gezondheidszorg & 35 & 37 & 22 & 6 \\
\hline Gedrag en maatschappij & 36 & 41 & 16 & 7 \\
\hline HBO totaal & 45 & 37 & 14 & 4 \\
\hline Landbouw & 36 & 46 & 15 & 4 \\
\hline Onderwijs & 49 & 31 & 14 & 6 \\
\hline Techniek & 45 & 37 & 13 & 5 \\
\hline Economie & 49 & 38 & 11 & 3 \\
\hline Gezondheidszorg & 44 & 34 & 16 & 6 \\
\hline Gedrag en maatschappij & 35 & 41 & 19 & 5 \\
\hline Kunst en cultuur & 47 & 31 & 14 & 8 \\
\hline Totaal & 33 & 41 & 19 & 7 \\
\hline
\end{tabular}

\section{Toelichting}

- Het gaat hier alleen om schoolverlaters die een voltijd vervolgopleiding zijn gaan volgen.

Vraag in de enquête:

- Hoe vindt u de aansluiting tussen uw [...] opleiding en deze vervolgopleiding? 
Tabel A2.4

Doorstroom van schoolverlaters naar de beroepsbegeleidende leerweg

$\begin{array}{lr}\text { MAVO } & 22 \\ \text { OVDB } & 14 \\ \text { ECABO } & 7 \\ \text { VEV/LOB-E } & 7 \\ \text { Handel/L-OVD } & 6 \\ \text { SVH } & \\ \text { HAVO } & 17 \\ \text { ECABO } & 11 \\ \text { SVH } & 11 \\ \text { OVDB } & 7 \\ \text { GOC } & 7 \\ \text { Handel/L-OVD } & 6 \\ \text { VTL } & \end{array}$

VWO

SVGB

LOBAS

SOM

GOC

IVBO

OVDB

LOBAS

ECABO

Handel/L-OVD

$\mathrm{SVH}$

11 7

VBO landbouw

LOBAS

OVDB

VBO techniek

VEV/LOB-E

SVB

INNOVAM

SVH

VBO economie

ECABO

Handel/L-OVD

OVDB

VBO gezondheidszorg

OVDB

Handel/L-OVD

KOC

BOL niveau 1/2 landbouw LOBAS 
Tabel A2.4 (vervolg)

Doorstroom van schoolverlaters naar de beroepsbegeleidende leerweg

BOL niveau $1 / 2$ techniek

VEV/LOB-E

INNOVAM

SOM

Intechnium

SOB\&B

BOL niveau $1 / 2$ economie

ECABO

Handel/L-OVD

SVH

OVDB

BOL niveau $1 / 2$ gezondheidszorg

OVDB

Handel/L-OVD

BOL niveau 3/4 landbouw

LOBAS

OVDB

BOL niveau 3/4 techniek

VaPro

VEV/LOB-E

SOM

VOC-Car

INNOVAM

BOL niveau 3/4 economie

ECABO

OVDB

Handel/L-OVD

SVH

KOC

BOL niveau $3 / 4$ gezondheidszorg

OVDB

BOL niveau 3/4 gedrag en maatschappij

OVDB

ECABO

$\mathrm{KOC}$

$B B L$ niveau 1/2 techniek

SVB

INNOVAM

SOM

SVS

Intechnium

VTL

VEV/LOB-E 
Tabel A2.4 (vervolg)

Doorstroom van schoolverlaters naar de beroepsbegeleidende leerweg

BBL niveau $1 / 2$ economie

SVH

Handel/L-OVD

BBL niveau 1/2 gezondheidszorg

OVDB

BBL niveau 3/4 techniek

SVB

Intechnium

Handel/L-OVD

INNOVAM

VEV/LOB-E

GOC

BBL niveau 3/4 economie

Handel/L-OVD

$\mathrm{SVH}$

OVDB

ECABO

SVO

OVDB

$B B L$ niveau $3 / 4$ gedrag en maatschappij OVDB

Toelichting

- In de tabel zijn alleen die opleidingen opgenomen die door ten minste 5\% van de schoolverlaters worden gevolgd. 
Tabel A3. 1

Werkloosheid en gemiddelde intredewerkloosheid van schoolverlaters die zich aanbieden op de arbeidsmarkt

\begin{tabular}{|c|c|c|c|c|c|c|c|c|}
\hline \multirow[t]{2}{*}{ Opleidingssector } & \multirow{2}{*}{$\begin{array}{r}\text { aanbieden op } \\
\text { arbeidsmarkt } \\
\% \\
\end{array}$} & \multirow{2}{*}{$\begin{array}{r}\text { werk- } \\
\text { loosheid } \\
\% \\
\end{array}$} & \multicolumn{5}{|c|}{ werkloos tijdens intredeperiode in klassen } & \multirow{2}{*}{$\begin{array}{r}\text { intrede- } \\
\text { werkloosheid } \\
\text { maanden }\end{array}$} \\
\hline & & & $\begin{array}{r}0 \text { mnd. } \\
\%\end{array}$ & $\begin{array}{r}1-3 \text { mnd. } \\
\%\end{array}$ & $\begin{array}{r}4-6 \text { mnd. } \\
\%\end{array}$ & $\begin{array}{r}7-12 \text { mnd. } \\
\%\end{array}$ & $\begin{array}{r}>=13 \text { mnd. } \\
\%\end{array}$ & \\
\hline VBO totaal & 44 & 4 & 82 & 15 & 2 & 1 & 0 & 0,5 \\
\hline IVBO & 54 & 12 & 78 & 16 & 5 & 1 & 1 & 0,6 \\
\hline Landbouw & 33 & 10 & 86 & 12 & 1 & 1 & 0 & 0,4 \\
\hline Techniek & 58 & 2 & 82 & 15 & 2 & 1 & 0 & 0,5 \\
\hline Economie & 32 & 7 & 84 & 14 & 2 & 0 & 0 & 0,3 \\
\hline Gezondheidszorg & 30 & 1 & 82 & 14 & 2 & 2 & 0 & 0,6 \\
\hline BOL niveau $1 / 2$ totaal & 74 & 4 & 81 & 12 & 3 & 3 & 1 & 0,8 \\
\hline Landbouw & 75 & 8 & 88 & 2 & 7 & 4 & 0 & 0,7 \\
\hline Techniek & 79 & 2 & 88 & 10 & 0 & 1 & 1 & 0,3 \\
\hline Economie & 75 & 5 & 78 & 13 & 3 & 4 & 1 & 1,0 \\
\hline Gezondheidszorg & 68 & 2 & 85 & 9 & 5 & 1 & 0 & 0,5 \\
\hline BOL niveau $3 / 4$ totaal & 62 & 2 & 89 & 9 & 1 & 1 & 0 & 0,3 \\
\hline Landbouw & 65 & 2 & 89 & 8 & 2 & 1 & 1 & 0,4 \\
\hline Techniek & 60 & 2 & 89 & 9 & 1 & 0 & 0 & 0,3 \\
\hline Economie & 60 & 2 & 89 & 9 & 1 & 0 & 0 & 0,2 \\
\hline Gezondheidszorg & 73 & 1 & 89 & 9 & 0 & 1 & 1 & 0,4 \\
\hline Gedrag en maatschappij & 60 & 3 & 85 & 11 & 2 & 1 & 0 & 0,4 \\
\hline
\end{tabular}


Tabel A3.1 (vervolg)

Werkloosheid en gemiddelde intredewerkloosheid van schoolverlaters die zich aanbieden op de arbeidsmarkt

\begin{tabular}{|c|c|c|c|c|c|c|c|c|}
\hline \multirow[t]{2}{*}{ Opleidingssector } & \multirow{2}{*}{$\begin{array}{r}\text { aanbieden op } \\
\text { arbeidsmarkt } \\
\%\end{array}$} & \multirow{2}{*}{$\begin{array}{r}\text { werk- } \\
\text { loosheid } \\
\%\end{array}$} & \multicolumn{5}{|c|}{ werkloos tijdens intredeperiode in klassen } & \multirow{2}{*}{$\begin{array}{r}\text { intrede- } \\
\text { werkloosheic } \\
\text { maanden }\end{array}$} \\
\hline & & & $\begin{array}{r}0 \text { mnd. } \\
\%\end{array}$ & $\begin{array}{r}1-3 \text { mnd. } \\
\%\end{array}$ & $\begin{array}{r}4-6 \text { mnd. } \\
\%\end{array}$ & $\begin{array}{r}7-12 \text { mnd. } \\
\%\end{array}$ & $\begin{array}{r}>=13 \text { mnd. } \\
\%\end{array}$ & \\
\hline BBL niveau $1 / 2$ totaal & 93 & 1 & 93 & 5 & 1 & 0 & 0 & 0,2 \\
\hline Techniek & 95 & 1 & 97 & 2 & 1 & 0 & 0 & 0,1 \\
\hline Economie & 90 & 1 & 86 & 11 & 1 & 1 & 0 & 0,4 \\
\hline Gezondheidszorg & 93 & 4 & 89 & 3 & 3 & 1 & 4 & 0,9 \\
\hline BBL niveau $3 / 4$ totaal & 96 & 0 & 94 & 4 & 1 & 1 & 0 & 0,2 \\
\hline Techniek & 95 & 0 & 99 & 0 & 0 & 0 & 0 & 0,0 \\
\hline Economie & 96 & 2 & 90 & 7 & 1 & 2 & 0 & 0,3 \\
\hline Gezondheidszorg & 95 & 0 & 95 & 5 & 0 & 0 & 0 & 0,1 \\
\hline Gedrag en maatschappij & 97 & 0 & 81 & 10 & 6 & 3 & 0 & 0,6 \\
\hline HBO totaal & 86 & 3 & 75 & 18 & 4 & 2 & 0 & 0,8 \\
\hline Landbouw & 91 & 2 & 73 & 20 & 5 & 2 & 0 & 0,8 \\
\hline Onderwijs & 89 & 3 & 79 & 15 & 4 & 2 & 0 & 0,6 \\
\hline Techniek & 85 & 2 & 74 & 20 & 3 & 2 & 1 & 0,8 \\
\hline Economie & 85 & 3 & 76 & 18 & 5 & 2 & 0 & 0,8 \\
\hline Gezondheidszorg & 90 & 3 & 75 & 19 & 4 & 2 & 0 & 0,8 \\
\hline Gedrag en maatschappij & 86 & 4 & 74 & 17 & 6 & 2 & 1 & 0,9 \\
\hline Kunst en cultuur & 74 & 11 & 55 & 24 & 12 & 7 & 1 & 2,1 \\
\hline
\end{tabular}


Tabel A3.1 (vervolg)

Werkloosheid en gemiddelde intredewerkloosheid van schoolverlaters die zich aanbieden op de arbeidsmarkt

\begin{tabular}{|c|c|c|c|c|c|c|c|c|}
\hline \multirow[t]{2}{*}{ Opleidingssector } & \multirow{2}{*}{$\begin{array}{r}\text { aanbieden op } \\
\text { arbeidsmarkt } \\
\%\end{array}$} & \multirow{2}{*}{$\begin{array}{r}\text { werk- } \\
\text { loosheid } \\
\%\end{array}$} & \multicolumn{5}{|c|}{ werkloos tijdens intredeperiode in klassen } & \multirow{2}{*}{$\begin{array}{r}\text { intrede- } \\
\text { werkloosheid } \\
\text { maanden }\end{array}$} \\
\hline & & & $\begin{array}{r}0 \text { mnd. } \\
\%\end{array}$ & $\begin{array}{r}1-3 \text { mnd. } \\
\%\end{array}$ & $\begin{array}{r}4-6 \text { mnd. } \\
\%\end{array}$ & $\begin{array}{r}\text { 7-12 mnd. } \\
\%\end{array}$ & $\begin{array}{r}>=13 \text { mnd. } \\
\%\end{array}$ & \\
\hline WO totaal & 96 & 2 & 72 & 19 & 6 & 2 & 0 & 0,9 \\
\hline Landbouw & 95 & 5 & 62 & 23 & 8 & 7 & 1 & 1,6 \\
\hline Techniek & 97 & 0 & 70 & 22 & 6 & 2 & 0 & 0,9 \\
\hline Economie & 98 & 1 & 77 & 16 & 6 & 1 & 0 & 0,7 \\
\hline Gezondheidszorg & 94 & 2 & 76 & 20 & 2 & 1 & 0 & 0,6 \\
\hline Gedrag en maatschappij & 96 & 3 & 70 & 20 & 7 & 3 & 0 & 1,0 \\
\hline Taal en cultuur & 93 & 4 & 69 & 19 & 7 & 3 & 1 & 1,2 \\
\hline Recht en openbare orde & 98 & 1 & 74 & 18 & 7 & 1 & 0 & 0,8 \\
\hline Natuurwetenschappen & 93 & 2 & 75 & 16 & 7 & 3 & 0 & 0,9 \\
\hline Totaal & 73 & 3 & 82 & 13 & 3 & 1 & 0 & 0,6 \\
\hline
\end{tabular}

Toelichting

- Het werkloosheidspercentage betreft hier de werkloze beroepsbevolking: schoolverlaters zonder werk (of met werk minder dan 12 uur per week) die minstens 12 uur per week willen werken, daarvoor direct beschikbaar zijn en bovendien actief zoeken naar werk (ongeacht of men bij een arbeidsbureau staat ingeschreven).

- De intredewerkloosheid betreft het aantal maanden dat schoolverlaters zichzelf als werkloos beschouwen.

- Het betreft hier alleen schoolverlaters die tot de beroepsbevolking behoren en zichzelf niet in de eerste plaats als student beschouwen 
Tabel A3.2

Aard van het dienstverband van werkende schoolverlaters

\begin{tabular}{|c|c|c|c|c|c|c|c|}
\hline Opleidingssector & $\begin{array}{r}\text { leer/werk- } \\
\text { overeen- } \\
\text { komst }\end{array}$ & $\begin{array}{l}\text { uitzend- } \\
\text { bureau }\end{array}$ & $\begin{array}{l}\text { loondienst } \\
\text { werkgever }\end{array}$ & $\begin{array}{c}\text { oproep- of } \\
\text { nul-uren } \\
\text { contract }\end{array}$ & $\begin{array}{r}\text { werk- } \\
\text { ervarings- } \\
\text { project }\end{array}$ & $\begin{array}{l}\text { bedrijf } \\
\text { ouders/ } \\
\text { partner }\end{array}$ & $\begin{array}{l}\text { eigen bedrijf/ } \\
\text { free-lance }\end{array}$ \\
\hline & $\%$ & $\%$ & $\%$ & $\%$ & $\%$ & $\%$ & $\%$ \\
\hline VBO totaal & 56 & 5 & 36 & 1 & 0 & 1 & $\mathbf{0}$ \\
\hline IVBO & 49 & 5 & 44 & 1 & 1 & 0 & 0 \\
\hline Landbouw & 63 & 4 & 28 & 2 & 1 & 2 & 1 \\
\hline Techniek & 62 & 4 & 32 & 1 & 0 & 1 & 1 \\
\hline Economie & 27 & 13 & 52 & 2 & 2 & 4 & 0 \\
\hline Gezondheidszorg & 63 & 3 & 35 & 0 & 0 & 0 & 0 \\
\hline BOL niveau $1 / 2$ totaal & 16 & 11 & 68 & 2 & 1 & 2 & $\mathbf{0}$ \\
\hline Landbouw & 13 & 6 & 78 & 2 & 1 & 0 & 0 \\
\hline Techniek & 27 & 9 & 60 & 2 & 0 & 1 & 0 \\
\hline Economie & 8 & 13 & 73 & 2 & 1 & 3 & 0 \\
\hline Gezondheidszorg & 32 & 6 & 55 & 5 & 1 & 0 & 0 \\
\hline BOL niveau $3 / 4$ totaal & 4 & 6 & 84 & 3 & 0 & 1 & 2 \\
\hline Landbouw & 3 & 8 & 78 & 1 & 0 & 3 & 7 \\
\hline Techniek & 1 & 8 & 88 & 1 & 0 & 1 & 2 \\
\hline Economie & 1 & 8 & 88 & 1 & 0 & 1 & 1 \\
\hline Gezondheidszorg & 12 & 2 & 78 & 5 & 1 & 0 & 1 \\
\hline Gedrag en maatschappij & 4 & 5 & 80 & 9 & 0 & 0 & 1 \\
\hline BBL niveau $1 / 2$ totaal & 20 & 2 & 75 & 0 & 0 & $\mathbf{0}$ & 1 \\
\hline Techniek & 19 & 1 & 77 & 0 & 0 & 0 & 2 \\
\hline Economie & 28 & 4 & 68 & 0 & 1 & 0 & 0 \\
\hline Gezondheidszorg & 6 & 1 & 91 & 0 & 2 & 0 & 0 \\
\hline
\end{tabular}


Tabel A3.2 (vervolg)

Aard van het dienstverband van werkende schoolverlaters

\begin{tabular}{|c|c|c|c|c|c|c|c|}
\hline Opleidingssector & $\begin{array}{r}\text { leer/werk- } \\
\text { overeen- } \\
\text { komst }\end{array}$ & $\begin{array}{c}\text { uitzend- } \\
\text { bureau }\end{array}$ & $\begin{array}{l}\text { loondienst } \\
\text { werkgever }\end{array}$ & $\begin{array}{c}\text { oproep- of } \\
\text { nul-uren } \\
\text { contract }\end{array}$ & $\begin{array}{l}\text { werk- } \\
\text { ervarings- } \\
\text { project }\end{array}$ & $\begin{array}{l}\text { bedrijf } \\
\text { ouders/ } \\
\text { partner }\end{array}$ & $\begin{array}{l}\text { eigen bedrijf/ } \\
\text { free-lance }\end{array}$ \\
\hline & $\%$ & $\%$ & $\%$ & $\%$ & $\%$ & $\%$ & $\%$ \\
\hline BBL niveau $3 / 4$ totaal & 2 & 2 & 93 & 1 & 0 & 1 & 1 \\
\hline Techniek & 0 & 1 & 96 & 0 & 0 & 0 & 3 \\
\hline Economie & 5 & 2 & 91 & 0 & 0 & 1 & 1 \\
\hline Gezondheidszorg & 2 & 4 & 93 & 0 & 0 & 1 & 0 \\
\hline Gedrag en maatschappij & 5 & 6 & 79 & 10 & 0 & 0 & 0 \\
\hline HBO totaal & 0 & 5 & 91 & 1 & 0 & 0 & 2 \\
\hline Landbouw & 0 & 10 & 82 & 1 & 0 & 1 & 5 \\
\hline Onderwijs & 0 & 4 & 94 & 2 & 0 & 0 & 1 \\
\hline Techniek & 0 & 6 & 92 & 0 & 0 & 1 & 1 \\
\hline Economie & 0 & 5 & 92 & 0 & 0 & 1 & 2 \\
\hline Gezondheidszorg & 0 & 4 & 91 & 2 & 0 & 0 & 2 \\
\hline Gedrag en maatschappij & 0 & 7 & 90 & 2 & 0 & 0 & 1 \\
\hline Kunst en cultuur & 0 & 3 & 70 & 1 & 0 & 0 & 25 \\
\hline WO totaal & 0 & 4 & 93 & $\mathbf{0}$ & 0 & $\mathbf{0}$ & 3 \\
\hline Landbouw & 0 & 9 & 88 & 0 & 0 & 0 & 3 \\
\hline Techniek & 0 & 2 & 95 & 0 & 0 & 0 & 3 \\
\hline Economie & 0 & 1 & 97 & 0 & 0 & 0 & 2 \\
\hline Gezondheidszorg & 0 & 2 & 95 & 0 & 0 & 0 & 3 \\
\hline Gedrag en maatschappij & 0 & 5 & 93 & 0 & 0 & 0 & 2 \\
\hline Taal en cultuur & 0 & 10 & 84 & 0 & 0 & 0 & 7 \\
\hline Recht en openbare orde & 0 & 2 & 97 & 0 & 0 & 0 & 1 \\
\hline Natuurwetenschappen & 0 & 6 & 93 & 0 & 0 & 0 & 1 \\
\hline Totaal & 11 & 5 & 80 & 1 & 0 & 1 & 2 \\
\hline
\end{tabular}


Tabel A3.3

Percentage werkende schoolverlaters met een flexibele aanstelling

VBO totaal

IVBO

Landbouw

Techniek

Economie

Gezondheidszorg

BOL niveau $1 / 2$ totaal

Landbouw

Techniek

Economie

Gezondheidszorg

BOL niveau 3/4 totaal

Landbouw

Techniek

Economie

Gezondheidszorg

Gedrag en maatschappij

BBL niveau $1 / 2$ totaal

Techniek

Economie

Gezondheidszorg

BBL niveau 3/4 totaal

Techniek

Economie

Gezondheidszorg

Gedrag en maatschappij

HBO totaal

Landbouw

Onderwijs

Techniek

Economie

Gezondheidszorg

Gedrag en maatschappij

18

Kunst en cultuur 
Tabel A3.3 (vervolg)

Percentage werkende schoolverlaters met een flexibele aanstelling

WO totaal

Landbouw

Techniek

Economie

4

Gezondheidszorg

3

Gedrag en maatschappij

Taal en cultuur $\quad 20$

Recht en openbare orde $\quad 5$

Natuurwetenschappen $\quad 10$

Totaal

\section{Toelichting}

- Voor het WO hebben de resultaten betrekking op 13 universiteiten.

- Een flexibele aanstelling betreft een aanstelling als uitzendkracht, oproepkracht e.d. of een aanstelling in tijdelijke dienst met een contract korter dan een jaar. 
Tabel A3. 4

Wijze van verkrijgen van een baan

\begin{tabular}{|c|c|c|c|c|c|c|c|c|c|c|c|}
\hline \multirow[t]{2}{*}{ Opleidingssector } & \multirow{2}{*}{$\begin{array}{r}\text { arbeids- } \\
\text { bureau } \\
\\
\% \\
\end{array}$} & \multirow{2}{*}{$\begin{array}{r}\text { uitzend- } \\
\text { bureau } \\
\\
\% \\
\end{array}$} & \multirow{2}{*}{$\begin{array}{r}\text { adver- } \\
\text { tentie } \\
\\
\\
\% \\
\end{array}$} & \multirow{2}{*}{$\begin{array}{r}\text { open } \\
\text { sollici- } \\
\text { tatie } \\
\\
\\
\quad \% \\
\end{array}$} & stage & $\begin{array}{r}\text { docent/ } \\
\text { ver.van } \\
\text { afgestud/ } \\
\text { alumni- } \\
\text { bureau ed. }\end{array}$ & $\begin{array}{r}\text { bedrijven } \\
\text { informatie } \\
\text { dagen }\end{array}$ & \multirow{2}{*}{$\begin{array}{r}\text { eerder } \\
\text { werk/ } \\
\text { interne } \\
\text { vacature } \\
\% \\
\%\end{array}$} & \multirow{2}{*}{$\begin{array}{r}\text { familie/ } \\
\text { vrienden/ } \\
\text { kennissen } \\
\% \\
\%\end{array}$} & \multirow{2}{*}{$\begin{array}{r}\text { zelf bedrijf } \\
\text { begonnen }\end{array}$} & \multirow{2}{*}{$\begin{array}{r}\text { anders } \\
\\
\\
\\
\% \\
\end{array}$} \\
\hline & & & & & $\%$ & $\%$ & $\%$ & & & & \\
\hline BOL niveau $1 / 2$ totaal & 9 & 14 & 11 & 14 & 20 & 5 & 1 & 2 & 16 & 0 & 7 \\
\hline Landbouw & 4 & 7 & 14 & 11 & 21 & 0 & 0 & 1 & 10 & 0 & 33 \\
\hline Techniek & 6 & 15 & 11 & 5 & 32 & 11 & 0 & 2 & 11 & 0 & 8 \\
\hline Economie & 10 & 15 & 12 & 14 & 18 & 2 & 0 & 3 & 19 & 0 & 6 \\
\hline Gezondheidszorg & 9 & 10 & 9 & 22 & 14 & 12 & 3 & 2 & 11 & 0 & 9 \\
\hline BOL niveau $3 / 4$ totaal & 5 & 15 & 16 & 16 & 20 & 2 & 1 & 4 & 10 & 1 & 8 \\
\hline Landbouw & 3 & 12 & 15 & 10 & 23 & 2 & 1 & 3 & 12 & 7 & 14 \\
\hline Techniek & 5 & 17 & 12 & 10 & 26 & 3 & 1 & 5 & 8 & 1 & 11 \\
\hline Economie & 7 & 23 & 19 & 11 & 17 & 2 & 0 & 3 & 11 & 1 & 6 \\
\hline Gezondheidszorg & 4 & 5 & 17 & 28 & 20 & 4 & 1 & 4 & 8 & 1 & 8 \\
\hline Gedrag en maatschappij & 4 & 10 & 17 & 25 & 18 & 1 & 0 & 4 & 11 & 1 & 8 \\
\hline HBO totaal & 2 & 17 & 20 & 16 & 16 & 2 & 1 & 4 & 10 & 1 & 10 \\
\hline Landbouw & 1 & 18 & 22 & 13 & 12 & 4 & 0 & 2 & 6 & 6 & 15 \\
\hline Onderwijs & 3 & 6 & 23 & 18 & 18 & 3 & 0 & 5 & 12 & 1 & 11 \\
\hline Techniek & 2 & 21 & 16 & 16 & 17 & 2 & 2 & 3 & 8 & 1 & 12 \\
\hline Economie & 2 & 21 & 20 & 13 & 16 & 2 & 2 & 3 & 11 & 2 & 7 \\
\hline Gezondheidszorg & 2 & 9 & 21 & 24 & 17 & 3 & 0 & 5 & 9 & 1 & 9 \\
\hline Gedrag en maatschappij & 3 & 19 & 24 & 16 & 14 & 2 & 0 & 5 & 9 & 1 & 7 \\
\hline Kunst en cultuur & 2 & 9 & 23 & 17 & 7 & 4 & 2 & 6 & 12 & 5 & 13 \\
\hline
\end{tabular}


Tabel A3.4 (vervolg)

Wijze van verkrijgen van een baan

\begin{tabular}{|c|c|c|c|c|c|c|c|c|c|c|c|}
\hline \multirow[t]{2}{*}{ Opleidingssector } & \multirow[t]{2}{*}{$\begin{array}{r}\text { arbeids- } \\
\text { bureau }\end{array}$} & $\begin{array}{c}\text { uitzend- } \\
\text { bureau }\end{array}$ & $\begin{array}{l}\text { adver- } \\
\text { tentie }\end{array}$ & $\begin{array}{r}\text { open } \\
\text { sollici- } \\
\text { tatie }\end{array}$ & \multicolumn{2}{|r|}{$\begin{array}{r}\text { docent/ } \\
\text { ver.van } \\
\text { afgestud/ } \\
\text { alumni- } \\
\text { bureau ed. }\end{array}$} & $\begin{array}{r}\text { bedrijven } \\
\text { informatie } \\
\text { dagen }\end{array}$ & $\begin{array}{r}\text { eerder } \\
\text { werk/ } \\
\text { interne } \\
\text { vacature }\end{array}$ & $\begin{array}{r}\text { familie/ } \\
\text { vrienden/ } \\
\text { kennissen }\end{array}$ & $\begin{array}{l}\text { zelf bedrijf } \\
\text { begonnen }\end{array}$ & \multirow{2}{*}{$\begin{array}{r}\text { anders } \\
\\
\% \\
\end{array}$} \\
\hline & & $\%$ & $\%$ & $\%$ & $\%$ & $\%$ & $\%$ & $\%$ & $\%$ & $\%$ & \\
\hline WO totaal & 1 & 11 & 23 & 24 & 10 & 6 & 3 & 4 & 9 & 2 & 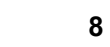 \\
\hline Landbouw & 2 & 10 & 30 & 12 & 11 & 11 & 1 & 1 & 6 & 2 & 14 \\
\hline Techniek & 1 & 10 & 15 & 30 & 10 & 9 & 5 & 3 & 7 & 3 & 8 \\
\hline Economie & 1 & 11 & 19 & 25 & 12 & 5 & 8 & 2 & 8 & 1 & 0 \\
\hline Gezondheidszorg & 0 & 5 & 24 & 39 & 7 & 3 & 0 & 4 & 9 & 1 & \\
\hline Gedrag en maatschappij & 2 & 12 & 27 & 15 & 11 & 5 & 1 & 6 & 11 & 1 & $y$ \\
\hline Taal en cultuur & 2 & 17 & 28 & 13 & 5 & 4 & 0 & 6 & 11 & 3 & 10 \\
\hline Recht en openbare orde & 0 & 10 & 27 & 29 & 10 & 3 & 2 & 2 & 8 & 1 & 7 \\
\hline Natuurwetenschappen & 1 & 9 & 24 & 18 & 15 & 13 & 2 & 3 & 8 & 1 & 7 \\
\hline Totaal & 4 & 15 & 19 & 17 & 17 & 3 & 1 & 4 & 10 & 1 & 9 \\
\hline
\end{tabular}

Toelichting

- Voor het WO hebben de resultaten betrekking op 10 universiteiten. 
Tabel A3.5

Belangrijkste bedrijfsgroepen waarin schoolverlaters werkzaam zijn

\section{IVBO}

Ov. gespec. detailh. in winkel

Burgerl./utilit.;grond-/water-/wegenb. (excl. grondverz.)

Restaurants/cafetaria's/snackbars e.d.

Drukkerijen/aanverwante activ.

\section{VBO landbouw}

Ov. gespec. detailh. in winkel

Niet-gespec. detailh. in winkel

Dienstverl. tbv landb. (excl. veterin.dienst.)

Ov. dienstverlening

\section{VBO techniek}

Handel in/repar. auto's (1)

Burgerl./utilit.;grond-/water-/wegenb. (excl. grondverz.)

Bouwinstallatie

Afwerken gebouwen

VBO economie

Niet-gespec. detailh. in winkel

Ov. gespec. detailh. in winkel

Overheidsdienst.

Gespec. detailh. voed.-/genotmid. in winkel

VBO gezondheidszorg

Welzijnszorg

Ov. dienstverlening

Niet-gespec. detailh. in winke

Ov. gespec. detailh. in winkel

Gespec. detailh. voed.-/genotmid. in winke

Restaurants/cafetaria's/snackbars e.d.

BOL niveau 1/2 landbouw

Ov. gespec. detailh. in winkel

Fokken/houden dieren

Bouwrijp maken terreinen

BOL niveau $1 / 2$ techniek

Bouwinstallatie

Burgerl./utilit.;grond-/water-/wegenb. (excl. grondverz.)

Handel in/repar. auto's (2)

Overheidsdienst.

BOL niveau $1 / 2$ economie

Ov. gespec. detailh. in winkel

Niet-gespec. detailh. in winkel

Restaurants/cafetaria's/snackbars e.d.

Hotels/pensions/conferentie-oorden

BOL niveau $1 / 2$ gezondheidszorg

Welzijnszorg

Ov. dienstverlening

Gezondheidszorg

Niet-gespec. detailh. in winkel 
Tabel A3.5 (vervolg)

Belangrijkste bedrijfsgroepen waarin schoolverlaters werkzaam zijn

BOL niveau 3/4 landbouw

Ov. gespec. detailh. in winkel

Fokken/houden dieren

Dienstverl. tbv landb. (excl. veterin.dienst.)

Akker-/tuinbouw

BOL niveau 3/4 techniek

Burgerl./utilit.;grond-/water-/wegenb. (excl. grondverz.)

Architecten-/ingenieurs-/ov. techn.ontw.-/teken-/adviesbur.

Bouwinstallatie

BOL niveau 3/4 economie

Rechtsk. dienstverl./account./belastingconsul./holdings e.d.

Ov. gespec. detailh. in winkel

Geldscheppende financ. instell.

Niet-gespec. detailh. in winkel

Hotels/pensions/conferentie-oorden

Reisorgan./-bemid.;informatieverstrek. op gebied toerisme

BOL niveau $3 / 4$ gezondheidszorg

Gezondheidszorg

Welzijnszorg

Detailh. farmac./med. art./parfum/cosmet. in winkel

BOL niveau 3/4 gedrag en maatschappij

Welzijnszorg

BBL niveau 1/2 techniek

Burgerl./utilit.;grond-/water-/wegenb. (excl. grondverz.)

Afwerken gebouwen

Bouwinstallatie

Vervoer over weg

BBL niveau 1/2 economie

Niet-gespec. detailh. in winkel

Restaurants/cafetaria's/snackbars e.d.

Hotels/pensions/conferentie-oorden

Ov. gespec. detailh. in winkel

Grooth. ov. consumentenart.

BBL niveau $1 / 2$ gezondheidszorg

Welzijnszorg

Ov. dienstverlening

Gezondheidszorg

Niet-gespec. detailh. in winkel

BBL niveau 3/4 techniek

Burgerl./utilit.;grond-/water-/wegenb. (excl. grondverz.)

Bouwinstallatie

Drukkerijen/aanverwante activ.

Handel in/repar. auto's (1)

Afwerken gebouwen 
Tabel A3.5 (vervolg)

Belangrijkste bedrijfsgroepen waarin schoolverlaters werkzaam zijn

BBL niveau 3/4 economie

Niet-gespec. detailh. in winkel

Restaurants/cafetaria's/snackbars e.d.

Ov. gespec. detailh. in winkel

Hotels/pensions/conferentie-oorden

BBL niveau 3/4 gezondheidszorg

Gezondheidszorg

Welzijnszorg

Ov. dienstverlening

BBL niveau 3/4 gedrag en maatschappij

Welzijnszorg

HBO landbouw

Rechtsk. dienstverl./account./belastingconsul./holdings e.d.

Architecten-/ingenieurs-/ov. techn.ontw.-/teken-/adviesbur.

Openbaar bestuur

Geldscheppende financ. instell.

HBO onderwijs

Basisonderwijs voor leerplichtingen/speciaal onderwijs

Voortgezet onderwijs

HBO techniek

Architecten-/ingenieurs-/ov. techn.ontw.-/teken-/adviesbur.

Burgerl./utilit.;grond-/water-/wegenb. (excl. grondverz.)

HBO economie

Rechtsk. dienstverl./account./belastingconsul./holdings e.d.

Geldscheppende financ. instell.

Uitzendbur./uitleenbedr./arbeidsbemid./testen/werven/select.

HBO gezondheidszorg

Gezondheidszorg

Welzijnszorg

HBO gedrag en maatschappij

Welzijnszorg

Gezondheidszorg

Uitzendbur./uitleenbedr./arbeidsbemid./testen/werven/select.

HBO kunst en cultuur

Overig amusement/kunst

Reklamebureaus e.d.

Ov. zakelijke dienstverl. n.e.g.

Voortgezet onderwijs

Ov. dienstverl. op gebied automat.

Architecten-/ingenieurs-/ov. techn.ontw.-/teken-/adviesbur. 
Tabel A3.5 (vervolg)

Belangrijkste bedrijfsgroepen waarin schoolverlaters werkzaam zijn

WO landbouw

Hoger onderwijs

Architecten-/ingenieurs-/ov. techn.ontw.-/teken-/adviesbur.

Natuurwet. speur-/ontwikkelingsw.

Openbaar bestuur

Speur-/ontwikkelingswerk

Rechtsk. dienstverl./account./belastingconsul./holdings e.d.

WO techniek

Architecten-/ingenieurs-/ov. techn.ontw.-/teken-/adviesbur.

Hoger onderwijs

Rechtsk. dienstverl./account./belastingconsul./holdings e.d.

Adviesbur. op gebied automat./systeemh.

WO economie

Rechtsk. dienstverl./account./belastingconsul./holdings e.d.

Geldscheppende financ. instell.

Adviesbur. op gebied automat./systeemh.

WO gezondheidszorg

Gezondheidszorg

Hoger onderwijs

WO gedrag en maatschappij

Rechtsk. dienstverl./account./belastingconsul./holdings e.d.

Gezondheidszorg

Openbaar bestuur

Welzijnszorg

Hoger onderwijs $\quad 8$

WO taal en cultuur

Hoger onderwijs

Uitgeverijen

Openbaar bestuur

Rechtsk. dienstverl./account./belastingconsul./holdings e.d.

Voortgezet onderwijs

WO recht en openbare orde

Rechtsk. dienstverl./account./belastingconsul./holdings e.d. 51

Overheidsdienst.

Openbaar bestuur

WO natuurwetenschappen

Hoger onderwijs

Gezondheidszorg

$\begin{array}{ll}\text { Detailh. farmac./med. art./parfum/cosmet. in winkel } & 9 \\ \text { Speur-/ontwikkelingswerk } & 5\end{array}$

\section{Toelichting}

- De bedrijven waarin de schoolverlaters werkzaam zijn, zijn geclassificeerd volgens de Standaard Bedrijfs Indeling van het CBS. Op het hier gepresenteerde niveau van bedrijfsgroepen worden in totaal 211 categorieën onderscheiden.

- In de tabel zijn alleen die bedrijfsgroepen weergegeven waarin ten minste 5\% van de schoolverlaters werkzaam is. 
Tabel A3.6

Belangrijkste beroepsgroepen waarin schoolverlaters werkzaam zijn

IVBO

Bouwvakkers

Verkopers 13

Hulpkrachten horeca en verzorging 12

Agrarische arbeider $\quad 10$

Laders en lossers $\quad 9$

\begin{tabular}{ll} 
Interieurverzorger & 8 \\
\hline
\end{tabular}

Assembleurs $\quad 7$

Metaalarbeiders $\quad 5$

Mechanisch operators

VBO landbouw

Verkopers

Agrarische arbeider

Hulpkrachten horeca en verzorging

Assembleurs

VBO techniek

Bouwvakkers

Metaalarbeiders

Assembleurs

Monteurs

Monteurs en controleurs elektrotechnische producten

Hulpkrachten horeca en verzorging

VBO economie

Verkopers

Receptionisten en administratieve employés

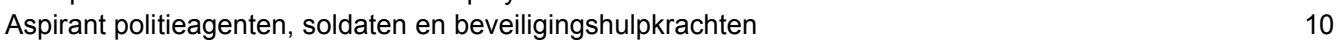

VBO gezondheidszorg

Verkopers

Hulpkrachten horeca en verzorging

Verpleeghulpen en leerling-verpleegkundigen

Mechanisch operators

Verzorgend personeel

BOL niveau 1/2 landbouw

Agrarische arbeider

Verkopers

Agrarische vakkrachten

Agrarische bedrijfshoofden

Weg- en waterbouwkundige vakkrachten

BOL niveau $1 / 2$ techniek

Aannemers en installateurs $\quad 15$

Monteurs $\quad 15$

Bouwvakkers $\quad 9$

Monteurs en controleurs elektrotechnische producten $\quad 9$

Elektromonteurs 
Tabel A3.6 (vervolg)

Belangrijkste beroepsgroepen waarin schoolverlaters werkzaam zijn

\section{BOL niveau $1 / 2$ economie}

Verkopers

Receptionisten en administratieve employés

Boekhouders en secretaresses

Verzorgend personeel

BOL niveau $1 / 2$ gezondheidszorg

Verzorgend personeel

Hulpkrachten horeca en verzorging

Verpleeghulpen en leerling-verpleegkundigen

Verkopers

BOL niveau 3/4 landbouw

Agrarische arbeider

Verkopers

Agrarische bedrijfshoofden

Agrarische vakkrachten

BOL niveau 3/4 techniek

Monteurs

Aannemers en installateurs

Elektromonteurs

Laboranten

Programmeurs

BOL niveau 3/4 economie

Boekhouders en secretaresses

Commercieel employés

Receptionisten en administratieve employés

Verkopers

Winkeliers

BOL niveau $3 / 4$ gezondheidszorg

Verplegenden en doktersassistenten

Verzorgend personeel

Ziekenverzorgenden

Apothekersassistenten en medisch laboranten

Verpleeghulpen en leerling-verpleegkundigen

Hulpkrachten horeca en verzorging

Verkopers

BOL niveau 3/4 gedrag en maatschappij

Verzorgend personeel

Activiteitenbegeleiders en medewerkers arbeidsbemiddeling

Hulpkrachten horeca en verzorging

BBL niveau $1 / 2$ techniek

Bouwvakkers

Aannemers en installateurs

Chauffeurs

Monteurs

Metaalarbeiders 
Tabel A3.6 (vervolg)

Belangrijkste beroepsgroepen waarin schoolverlaters werkzaam zijn

BBL niveau 1/2 economie

Verkopers

Hulpkrachten horeca en verzorging

Verzorgend personeel

Receptionisten en administratieve employés

BBL niveau $1 / 2$ gezondheidszorg

Verzorgend personeel

Hulpkrachten horeca en verzorging

Ziekenverzorgenden

Verkopers

Verpleeghulpen en leerling-verpleegkundigen

BBL niveau 3/4 techniek

Aannemers en installateurs

Bouwvakkers

Monteurs

Weg- en waterbouwkundige arbeiders

Grafisch productiepersoneel

Weg- en waterbouwkundige vakkrachten

BBL niveau 3/4 economie

Verzorgend personeel

Winkeliers

Verkopers

Hulpkrachten horeca en verzorging

Boekhouders en secretaresses

BBL niveau $3 / 4$ gezondheidszorg

Verplegenden en doktersassistenten

Verzorgend personeel

Ziekenverzorgenden

Hulpkrachten horeca en verzorging

BBL niveau $3 / 4$ gedrag en maatschappij

Verzorgend personeel

Activiteitenbegeleiders en medewerkers arbeidsbemiddeling

HBO landbouw

Milieuhygienisten en agrarisch vertegenwoordigers

Assistent accountants

Agrarische bedrijfshoofden

Commercieel medewerkers

Commercieel employés

Procestechnologen

HBO onderwijs

Leraar basisonderwijs

Docenten talen en expressie

Docenten sociale vakken (2e en $3 e$ gr.) 
Tabel A3.6 (vervolg)

Belangrijkste beroepsgroepen waarin schoolverlaters werkzaam zijn

HBO techniek

Systeemanalisten

Architecten en bouwkundig projectleiders

We rktuigbouwkundig ontwerpers en hoofden technische dienst

HBO economie

Commercieel medewerkers $\quad 26$

$\begin{array}{lr}\text { Assistent accountants } & 19\end{array}$

Commercieel employés $\quad 10$

\begin{tabular}{ll} 
Systeemanalisten & 8 \\
\hline
\end{tabular}

$\begin{array}{ll}\text { Organisatie-adviseurs } & 7\end{array}$

HBO gezondheidszorg

$\begin{array}{ll}\text { Therapeuten en verpleegkundigen } & 76\end{array}$

$\begin{array}{ll}\text { Verplegenden en doktersassistenten } & 6\end{array}$

HBO gedrag en maatschappij

Sociaal-cultureel werkers

Activiteitenbegeleiders en medewerkers arbeidsbemiddeling

Verzorgend personeel

HBO kunst en cultuur

Kunstenaars

Docenten talen en expressie

Architecten en bouwkundig projectleiders

WO landbouw

Landbouwkundigen

Natuurwetenschappers

Artsen

Milieuhygienisten en agrarisch vertegenwoordigers

Materiaalkundigen

6

\section{WO techniek}

Weg-en waterbouwkundigen $\quad 17$

Materiaalkundigen 12

Werktuigbouwkundigen $\quad 8$

$\begin{array}{ll}\text { Organisatiedeskundigen } & 8\end{array}$

$\begin{array}{ll}\text { Elektrotechnici } & 7\end{array}$

$\begin{array}{ll}\text { Architecten en bouwkundig projectleiders } & 6\end{array}$

$\begin{array}{ll}\text { Organisatie-adviseurs } & 6\end{array}$

$\begin{array}{ll}\text { Systeemanalisten } & 6\end{array}$

Informatici $\quad 5$

WO economie

Economen

$\begin{array}{ll}\text { Organisatiedeskundigen } & 15\end{array}$

Assistent accountants $\quad 11$

\begin{tabular}{ll} 
Systeemanalisten & 7 \\
\hline
\end{tabular}

$\begin{array}{ll}\text { Accountants } & 7\end{array}$ 
Tabel A3.6 (vervolg)

Belangrijkste beroepsgroepen waarin schoolverlaters werkzaam zijn

WO gezondheidszorg

Artsen

WO gedrag en maatschappij

$\begin{array}{ll}\text { Sociaal-wetenschappelijk onderzoekers } & 21\end{array}$

Sociaal-cultureel werkers $\quad 10$

$\begin{array}{ll}\text { Onderwijskundigen en pedagogen } & 8\end{array}$

$\begin{array}{ll}\text { Commercieel medewerkers } & 7\end{array}$

$\begin{array}{ll}\text { Organisatiedeskundigen } & 5\end{array}$

WO taal en cultuur

Commercieel medewerkers $\quad 11$

Journalisten $\quad 10$

Taalkundigen $\quad 9$

WO recht en openbare orde

Juristen

WO natuurwetenschappen

Natuurwetenschappers

$\begin{array}{lr}\text { Systeemanalisten } & 9\end{array}$

\section{Toelichting}

- De beroepen waarin de schoolverlaters werkzaam zijn, zijn geclassificeerd volgens de Standaard Beroepenclassificatie 1992 van het CBS. Binnen de elementaire beroepen is hierbij door het ROA een nader onderscheid gemaakt. Bovendien zijn de namen van de beroepen verduidelijkt. Op het hier gepresenteerde niveau van beroepsgroepen worden in totaal 127 categorieën onderscheiden.

- In de tabel zijn alleen die beroepsgroepen weergegeven waarin ten minste $5 \%$ van de schoolverlaters werkzaam is. 
Tabel A3.7

Grootte van de organisatie waarin schoolverlaters werkzaam zijn

\begin{tabular}{|c|c|c|c|c|c|}
\hline \multirow[t]{2}{*}{ Opleidingssector } & 1 pers & $\begin{array}{r}2 \mathrm{t} / \mathrm{m} 9 \\
\text { pers }\end{array}$ & $\begin{array}{r}10 \mathrm{t} / \mathrm{m} 99 \\
\text { pers }\end{array}$ & $\begin{array}{r}100 \mathrm{t} / \mathrm{m} 999 \\
\text { pers }\end{array}$ & $\begin{array}{r}>=1000 \\
\text { pers }\end{array}$ \\
\hline & $\%$ & $\%$ & $\%$ & $\%$ & $\%$ \\
\hline VBO totaal & 1 & 21 & 50 & 16 & 12 \\
\hline IVBO & & 25 & 60 & 10 & 6 \\
\hline Landbouw & 1 & 39 & 32 & 19 & 10 \\
\hline Techniek & 2 & 18 & 58 & 15 & 7 \\
\hline Economie & & 16 & 35 & 16 & 34 \\
\hline Gezondheidszorg & & 28 & 37 & 24 & 12 \\
\hline BOL niveau $1 / 2$ totaal & 0 & 19 & 34 & 25 & 21 \\
\hline Landbouw & 9 & 46 & 32 & 8 & 5 \\
\hline Techniek & & 18 & 42 & 18 & 21 \\
\hline Economie & 0 & 18 & 32 & 26 & 23 \\
\hline Gezondheidszorg & & 18 & 34 & 30 & 18 \\
\hline BOL niveau $3 / 4$ totaal & 1 & 14 & 32 & 27 & 25 \\
\hline Landbouw & 8 & 39 & 30 & 13 & 10 \\
\hline Techniek & 1 & 12 & 35 & 26 & 26 \\
\hline Economie & 0 & 12 & 35 & 24 & 28 \\
\hline Gezondheidszorg & 1 & 15 & 24 & 32 & 29 \\
\hline Gedrag en maatschappij & 0 & 8 & 32 & 38 & 22 \\
\hline BBL niveau $1 / 2$ totaal & 0 & 18 & 41 & 23 & 18 \\
\hline Techniek & 1 & 20 & 42 & 24 & 14 \\
\hline Economie & & 17 & 43 & 15 & 25 \\
\hline Gezondheidszorg & & 8 & 26 & 51 & 14 \\
\hline BBL niveau $3 / 4$ totaal & 1 & 14 & 31 & 26 & 28 \\
\hline Techniek & 1 & 22 & 41 & 19 & 17 \\
\hline Economie & 0 & 14 & 48 & 16 & 22 \\
\hline Gezondheidszorg & 1 & 9 & 13 & 36 & 40 \\
\hline Gedrag en maatschappij & & 9 & 43 & 29 & 19 \\
\hline HBO totaal & 1 & 7 & 30 & 29 & 33 \\
\hline Landbouw & 1 & 11 & 21 & 36 & 30 \\
\hline Onderwijs & 0 & 5 & 62 & 25 & 8 \\
\hline Techniek & 0 & 5 & 26 & 28 & 41 \\
\hline Economie & 1 & 6 & 24 & 27 & 42 \\
\hline Gezondheidszorg & 1 & 19 & 14 & 28 & 38 \\
\hline Gedrag en maatschappij & 0 & 4 & 23 & 44 & 29 \\
\hline Kunst en cultuur & 10 & 25 & 41 & 17 & 6 \\
\hline
\end{tabular}


Tabel A3.7 (vervolg)

Grootte van de organisatie waarin schoolverlaters werkzaam zijn

\begin{tabular}{|c|c|c|c|c|c|}
\hline \multirow[t]{2}{*}{ Opleidingssector } & 1 pers & $\begin{array}{r}2 \mathrm{t} / \mathrm{m} 9 \\
\text { pers }\end{array}$ & $\begin{array}{r}10 \mathrm{t} / \mathrm{m} 99 \\
\text { pers }\end{array}$ & $\begin{array}{r}100 \mathrm{t} / \mathrm{m} 999 \\
\text { pers }\end{array}$ & $\begin{array}{r}>=1000 \\
\text { pers }\end{array}$ \\
\hline & $\%$ & $\%$ & $\%$ & $\%$ & $\%$ \\
\hline WO totaal & 1 & 6 & 21 & 27 & 46 \\
\hline Landbouw & 1 & 6 & 17 & 33 & 44 \\
\hline Techniek & 1 & 6 & 22 & 20 & 51 \\
\hline Economie & 0 & 3 & 14 & 22 & 61 \\
\hline Gezondheidszorg & 0 & 8 & 11 & 31 & 49 \\
\hline Gedrag en maatschappij & 1 & 7 & 26 & 30 & 37 \\
\hline Taal en cultuur & 3 & 11 & 30 & 25 & 30 \\
\hline Recht en openbare orde & 0 & 5 & 22 & 34 & 39 \\
\hline Natuurwetenschappen & 0 & 4 & 19 & 23 & 53 \\
\hline Totaal & 1 & 13 & 34 & 26 & 27 \\
\hline
\end{tabular}

\section{Toelichting}

- Voor het WO hebben de resultaten betrekking op 10 universiteiten.

Vraag in de enquête:

- Hoeveel mensen werken er bij de organisatie of het bedrijf waar u werkzaam bent? Het gaat hier om alle werknemers van het totale concern (hoofd- en nevenvestigingen samen). 
Tabel A3.8

Beloning van werkende schoolverlaters

\begin{tabular}{|c|c|c|}
\hline Opleidingssector & $\begin{array}{r}\text { gemiddeld } \\
\text { bruto maandloon } \\
\text { guldens }\end{array}$ & $\begin{array}{r}\text { gemiddeld } \\
\text { bruto uurloon } \\
\text { guldens }\end{array}$ \\
\hline VBO totaal & 1.353 & 9,28 \\
\hline IVBO & 1.405 & 9,50 \\
\hline Landbouw & 1.134 & 8,23 \\
\hline Techniek & 1.409 & 9,40 \\
\hline Economie & 1.313 & 9,05 \\
\hline Gezondheidszorg & 1.236 & 9,28 \\
\hline BOL niveau $1 / 2$ totaal & 2.035 & 13,48 \\
\hline Landbouw & 1.715 & 11,27 \\
\hline Techniek & 2.245 & 13,76 \\
\hline Economie & 2.066 & 13,40 \\
\hline Gezondheidszorg & 1.753 & 13,87 \\
\hline BOL niveau $3 / 4$ totaal & 2.710 & 17,75 \\
\hline Landbouw & 2.490 & 15,76 \\
\hline Techniek & 3.301 & 19,65 \\
\hline Economie & 2.648 & 16,65 \\
\hline Gezondheidszorg & 2.382 & 17,04 \\
\hline Gedrag en maatschappij & 2.396 & 18,66 \\
\hline BBL niveau $1 / 2$ totaal & 2.495 & 16,71 \\
\hline Techniek & 2.761 & 17,89 \\
\hline Economie & 2.108 & 14,28 \\
\hline Gezondheidszorg & 2.140 & 17,11 \\
\hline BBL niveau $3 / 4$ totaal & 3.194 & 21,46 \\
\hline Techniek & 3.716 & 22,44 \\
\hline Economie & 2.931 & 18,01 \\
\hline Gezondheidszorg & 3.114 & 22,80 \\
\hline Gedrag en maatschappij & 2.238 & 18,89 \\
\hline HBO totaal & 3.827 & 25,05 \\
\hline Landbouw & 3.758 & 23,18 \\
\hline Onderwijs & 3.786 & 27,08 \\
\hline Techniek & 4.163 & 24,89 \\
\hline Economie & 3.975 & 24,32 \\
\hline Gezondheidszorg & 3.390 & 26,55 \\
\hline Gedrag en maatschappij & 3.374 & 24,38 \\
\hline Kunst en cultuur & 3.286 & 23,93 \\
\hline
\end{tabular}


Tabel A3.8 (vervolg)

Beloning van werkende schoolverlaters

\begin{tabular}{lrr} 
Opleidingssector & $\begin{array}{r}\text { gemiddeld } \\
\text { bruto maandloon } \\
\text { guldens }\end{array}$ & $\begin{array}{r}\text { gemiddeld } \\
\text { bruto uurloon } \\
\text { guldens }\end{array}$ \\
\hline WO totaal & 4.547 & $\mathbf{2 9 , 1 8}$ \\
Landbouw & 3.925 & 24,90 \\
Techniek & 4.892 & 29,40 \\
Economie & 5.068 & 30,47 \\
Gezondheidszorg & 5.083 & 32,02 \\
Gedrag en maatschappij & 4.215 & 29,58 \\
Taal en cultuur & 3.795 & 27,22 \\
Recht en openbare orde & 4.781 & 29,02 \\
Natuurwetenschappen & 3.837 & 25,60 \\
Totaal & & $\mathbf{2 0 , 5 4}$
\end{tabular}

\section{Toelichting}

- Dit betreft het bruto inkomen in de baan waarin men het hoogste aantal uren werkt. Dit is inclusief toeslagen voor ploegendienst, fooien, provisie e.d. maar exclusief inkomen uit overwerk, vakantiegeld, $13^{e}$ maand, uitkering, e.d. Er is hier niet gecorrigeerd voor verschillen in leeftijd van de schoolverlaters. 
Tabel A3.9

Vereist opleidingsniveau voor de huidige functie volgens de werkgever

\begin{tabular}{|c|c|c|c|}
\hline Opleidingssector & $\begin{array}{r}\text { lager } \\
\% \\
\end{array}$ & $\begin{array}{r}\text { zelfde } \\
\% \\
\end{array}$ & $\begin{array}{r}\text { hoger } \\
\% \\
\end{array}$ \\
\hline VBO totaal & 31 & 61 & 8 \\
\hline IVBO & 43 & 54 & 3 \\
\hline Landbouw & 26 & 64 & 10 \\
\hline Techniek & 33 & 60 & 7 \\
\hline Economie & 30 & 54 & 16 \\
\hline Gezondheidszorg & 20 & 74 & 6 \\
\hline BOL niveau $1 / 2$ totaal & 47 & 25 & 28 \\
\hline Landbouw & 48 & 13 & 39 \\
\hline Techniek & 47 & 43 & 10 \\
\hline Economie & 46 & 23 & 31 \\
\hline Gezondheidszorg & 50 & 15 & 36 \\
\hline BOL niveau $3 / 4$ totaal & 21 & 77 & 2 \\
\hline Landbouw & 33 & 67 & 0 \\
\hline Techniek & 17 & 81 & 3 \\
\hline Economie & 21 & 76 & 3 \\
\hline Gezondheidszorg & 23 & 76 & 1 \\
\hline Gedrag en maatschappij & 21 & 78 & 2 \\
\hline BBL niveau $1 / 2$ totaal & 57 & 22 & 22 \\
\hline Techniek & 59 & 24 & 16 \\
\hline Economie & 59 & 16 & 25 \\
\hline Gezondheidszorg & 29 & 20 & 50 \\
\hline BBL niveau $3 / 4$ totaal & 41 & 55 & 4 \\
\hline Techniek & 62 & 38 & \\
\hline Economie & 51 & 47 & 2 \\
\hline Gezondheidszorg & 22 & 71 & 7 \\
\hline Gedrag en maatschappij & 34 & 63 & 3 \\
\hline HBO totaal & 20 & 79 & 1 \\
\hline Landbouw & 25 & 74 & 1 \\
\hline Onderwijs & 11 & 89 & 0 \\
\hline Techniek & 15 & 84 & 1 \\
\hline Economie & 21 & 78 & 1 \\
\hline Gezondheidszorg & 18 & 82 & 0 \\
\hline Gedrag en maatschappij & 34 & 66 & 0 \\
\hline Kunst en cultuur & 33 & 66 & 1 \\
\hline
\end{tabular}

Wo totaal

Landbouw

Techniek

Economie

Gezondheidszorg

Gedrag en maatschappij

Taal en cultuur

Recht en openbare orde

Natuurwetenschappen

Totaal

Toelichting

Vraag in de enquête:

- Welk opleidingsniveau werd door uw werkgever voor deze functie minimaal vereist? 
Tabel A3.10

Vereiste opleidingsrichting voor de huidige functie volgens de werkgever

\begin{tabular}{|c|c|c|c|}
\hline Opleidingssector & $\begin{array}{r}\text { eigen/ } \\
\text { verwante } \\
\text { richting } \\
\%\end{array}$ & $\begin{array}{l}\text { andere } \\
\text { richting }\end{array}$ & $\begin{array}{r}\text { geen } \\
\text { richting }\end{array}$ \\
\hline VBO totaal & 53 & 7 & 41 \\
\hline IVBO & 37 & 11 & 52 \\
\hline Landbouw & 46 & 6 & 48 \\
\hline Techniek & 65 & 6 & 28 \\
\hline Economie & 25 & 6 & 69 \\
\hline Gezondheidszorg & 49 & 4 & 47 \\
\hline BOL niveau $1 / 2$ totaal & 55 & 7 & 39 \\
\hline Landbouw & 65 & 2 & 33 \\
\hline Techniek & 58 & 4 & 39 \\
\hline Economie & 50 & 8 & 41 \\
\hline Gezondheidszorg & 68 & 5 & 28 \\
\hline BOL niveau $3 / 4$ totaal & 74 & 5 & 21 \\
\hline Landbouw & 65 & 6 & 29 \\
\hline Techniek & 81 & 3 & 15 \\
\hline Economie & 66 & 6 & 28 \\
\hline Gezondheidszorg & 83 & 3 & 15 \\
\hline Gedrag en maatschappij & 75 & 5 & 20 \\
\hline BBL niveau $1 / 2$ totaal & 56 & 6 & 37 \\
\hline Techniek & 61 & 4 & 35 \\
\hline Economie & 43 & 12 & 45 \\
\hline Gezondheidszorg & 70 & 3 & 27 \\
\hline BBL niveau $3 / 4$ totaal & 77 & 4 & 19 \\
\hline Techniek & 75 & 5 & 20 \\
\hline Economie & 60 & 4 & 37 \\
\hline Gezondheidszorg & 86 & 3 & 11 \\
\hline Gedrag en maatschappij & 75 & 8 & 17 \\
\hline HBO totaal & 77 & 4 & 19 \\
\hline Landbouw & 78 & 5 & 18 \\
\hline Onderwijs & 87 & 3 & 10 \\
\hline Techniek & 80 & 4 & 16 \\
\hline Economie & 64 & 5 & 31 \\
\hline Gezondheidszorg & 93 & 2 & 5 \\
\hline Gedrag en maatschappij & 76 & 7 & 17 \\
\hline Kunst en cultuur & 76 & 7 & 17 \\
\hline
\end{tabular}


Tabel A3.10 (vervolg)

Vereiste opleidingsrichting voor de huidige functie volgens de werkgever

\begin{tabular}{lrrr} 
Opleidingssector & $\begin{array}{r}\text { eigen/ } \\
\text { verwante } \\
\text { richting } \\
\%\end{array}$ & $\begin{array}{c}\text { andere } \\
\text { richting }\end{array}$ & $\begin{array}{r}\text { geen } \\
\text { richting }\end{array}$ \\
\hline Wo totaal & $\mathbf{\%}$ & $\%$ & $\%$ \\
Landbouw & 75 & $\mathbf{5}$ & $\mathbf{2 4}$ \\
Techniek & 75 & 6 & 19 \\
Economie & 71 & 3 & 23 \\
Gezondheidszorg & 92 & 2 & 27 \\
Gedrag en maatschappij & 62 & 2 & 6 \\
Taal en cultuur & 44 & 8 & 44 \\
Recht en openbare orde & 80 & 12 & 16 \\
Natuurwetenschappen & 79 & 3 & 18 \\
& & 3 & $\mathbf{2 6}$ \\
Totaal & $\mathbf{6 9}$ & $\mathbf{5}$ & \\
\hline
\end{tabular}

Toelichting

Vraag in de enquête:

- Welke opleidingsrichting werd door uw werkgever voor deze functie vereist? 
Tabel A3.11

Gewenste en feitelijke wekelijkse arbeidsduur van werkende schoolverlaters

\begin{tabular}{|c|c|c|}
\hline Opleidingssector & $\begin{array}{r}\text { gewenste } \\
\text { wekelijkse } \\
\text { arbeidsduur } \\
\text { uren }\end{array}$ & $\begin{array}{r}\text { feitelijke } \\
\text { wekelijkse } \\
\text { arbeidsduur } \\
\text { uren } \\
\end{array}$ \\
\hline VBO totaal & 37,0 & 33,7 \\
\hline IVBO & 35,4 & 33,6 \\
\hline Landbouw & 36,0 & 31,5 \\
\hline Techniek & 39,2 & 34,7 \\
\hline Economie & 35,2 & 32,8 \\
\hline Gezondheidszorg & 33,1 & 32,2 \\
\hline BOL niveau $1 / 2$ totaal & 37,1 & 36,7 \\
\hline Landbouw & 37,8 & 37,0 \\
\hline Techniek & 39,1 & 38,9 \\
\hline Economie & 37,1 & 37,3 \\
\hline Gezondheidszorg & 34,1 & 32,1 \\
\hline BOL niveau $3 / 4$ totaal & 37,4 & 36,8 \\
\hline Landbouw & 39,9 & 40,2 \\
\hline Techniek & 39,9 & 39,8 \\
\hline Economie & 38,2 & 38,2 \\
\hline Gezondheidszorg & 34,7 & 33,7 \\
\hline Gedrag en maatschappij & 34,0 & 31,5 \\
\hline BBL niveau $1 / 2$ totaal & 38,6 & 36,1 \\
\hline Techniek & 41,2 & 38,0 \\
\hline Economie & 35,8 & 34,2 \\
\hline Gezondheidszorg & 31,5 & 29,9 \\
\hline BBL niveau $3 / 4$ totaal & 35,2 & 35,1 \\
\hline Techniek & 38,2 & 38,9 \\
\hline Economie & 37,6 & 37,2 \\
\hline Gezondheidszorg & 32,6 & 32,3 \\
\hline Gedrag en maatschappij & 30,0 & 27,9 \\
\hline HBO totaal & 36,4 & 36,9 \\
\hline Landbouw & 37,3 & 39,4 \\
\hline Onderwijs & 34,7 & 34,5 \\
\hline Techniek & 38,4 & 39,4 \\
\hline Economie & 37,7 & 38,7 \\
\hline Gezondheidszorg & 34,0 & 33,1 \\
\hline Gedrag en maatschappij & 34,4 & 33,7 \\
\hline Kunst en cultuur & 32,7 & 33,3 \\
\hline
\end{tabular}


Tabel A3.11 (vervolg)

Gewenste en feitelijke wekelijkse arbeidsduur van werkende schoolverlaters

\begin{tabular}{lrr} 
Opleidingssector & $\begin{array}{r}\text { gewenste } \\
\text { wekelijkse } \\
\text { arbeidsduur } \\
\text { uren }\end{array}$ & $\begin{array}{r}\text { feitelijke } \\
\text { wekelijkse } \\
\text { arbeidsduur } \\
\text { uren }\end{array}$ \\
\hline Wo totaal & & $\mathbf{3 7 , 9}$ \\
Landbouw & $\mathbf{3 6 , 8}$ & 36,9 \\
Techniek & 36,5 & 39,3 \\
Economie & 38,5 & 39,6 \\
Gezondheidszorg & 38,8 & 38,9 \\
Gedrag en maatschappij & 36,9 & 35,9 \\
Taal en cultuur & 35,0 & 36,0 \\
Recht en openbare orde & 34,5 & 38,7 \\
Natuurwetenschappen & 37,2 & 37,5 \\
& 36,1 & $\mathbf{3 6 , 3}$
\end{tabular}

\section{Toelichting}

- De feitelijke arbeidsduur betreft zowel het aantal uren in de hoofdfunctie als het aantal uren in eventuele nevenfuncties.

De gewenste wekelijkse arbeidsduur is bepaald op basis van de vraag in de enquête:

- Als u zelf zou mogen kiezen, hoeveel uren per week zou u dan het liefst betaald werk willen hebben? 
Tabel A3.12

Oordeel van de werkende schoolverlaters over de aansluiting tussen de afgesloten opleiding en de huidige functie

\begin{tabular}{|c|c|c|c|c|}
\hline Opleidingssector & $\begin{array}{r}\text { goed } \\
\%\end{array}$ & $\begin{array}{r}\text { voldoende } \\
\%\end{array}$ & $\begin{array}{r}\text { matig } \\
\%\end{array}$ & $\begin{array}{r}\text { slecht } \\
\%\end{array}$ \\
\hline BOL niveau $1 / 2$ totaal & 51 & 25 & 13 & 12 \\
\hline Landbouw & 53 & 24 & 9 & 14 \\
\hline Techniek & 47 & 33 & 13 & 8 \\
\hline Economie & 50 & 24 & 15 & 11 \\
\hline Gezondheidszorg & 61 & 19 & 3 & 17 \\
\hline BOL niveau $3 / 4$ totaal & 47 & 34 & 12 & 7 \\
\hline Landbouw & 46 & 32 & 12 & 10 \\
\hline Techniek & 44 & 37 & 14 & 5 \\
\hline Economie & 43 & 37 & 14 & 7 \\
\hline Gezondheidszorg & 59 & 28 & 7 & 6 \\
\hline Gedrag en maatschappij & 49 & 31 & 9 & 11 \\
\hline BBL niveau $1 / 2$ totaal & 59 & 27 & 7 & 7 \\
\hline Techniek & 60 & 26 & 5 & 9 \\
\hline Economie & 56 & 30 & 10 & 3 \\
\hline Gezondheidszorg & 62 & 28 & 8 & 2 \\
\hline BBL niveau $3 / 4$ totaal & 58 & 32 & 7 & 3 \\
\hline Techniek & 61 & 30 & 8 & 1 \\
\hline Economie & 50 & 34 & 9 & 7 \\
\hline Gezondheidszorg & 58 & 35 & 4 & 3 \\
\hline Gedrag en maatschappij & 62 & 25 & 10 & 3 \\
\hline HBO totaal & 48 & 37 & 11 & 4 \\
\hline Landbouw & 42 & 41 & 10 & 7 \\
\hline Onderwijs & 60 & 28 & 7 & 5 \\
\hline Techniek & 45 & 41 & 11 & 3 \\
\hline Economie & 44 & 39 & 12 & 4 \\
\hline Gezondheidszorg & 55 & 32 & 10 & 3 \\
\hline Gedrag en maatschappij & 41 & 39 & 15 & 5 \\
\hline Kunst en cultuur & 41 & 38 & 13 & 8 \\
\hline WO totaal & 53 & 33 & 9 & 5 \\
\hline Landbouw & 54 & 32 & 7 & 7 \\
\hline Techniek & 51 & 38 & 9 & 3 \\
\hline Economie & 55 & 34 & 7 & 3 \\
\hline Gezondheidszorg & 67 & 26 & 5 & 2 \\
\hline Gedrag en maatschappij & 43 & 36 & 14 & 7 \\
\hline Taal en cultuur & 32 & 35 & 15 & 18 \\
\hline Recht en openbare orde & 61 & 29 & 8 & 3 \\
\hline Natuurwetenschappen & 53 & 30 & 9 & 8 \\
\hline Totaal & 51 & 33 & 10 & 6 \\
\hline
\end{tabular}

Toelichting

- Voor het WO hebben de resultaten betrekking op 10 universiteiten.

Vraag in de enquête:

- Hoe vindt $u$ de aansluiting tussen uw [...] opleiding en uw huidige functie? 
Tabel A3.13

Percentage werkende schoolverlaters dat op zoek is naar een andere baan

VBO totaal

IVBO

Landbouw

Techniek

Economie

Gezondheidszorg

BOL niveau 1/2 totaal

Landbouw

Techniek

Economie

Gezondheidszorg

BOL niveau 3/4 totaal

Landbouw

Techniek

Economie

Gezondheidszorg

Gedrag en maatschappij

BBL niveau 1/2 totaal

Techniek

Economie

Gezondheidszorg

(2)

BBL niveau 3/4 totaal

Techniek

Economie

Gezondheidszorg

Gedrag en maatschappij

HBO totaal

Landbouw

Onderwijs

Techniek

Economie

Gezondheidszorg

Gedrag en maatschappij

Kunst en cultuur

WO totaal

Landbouw

Techniek

Economie

Gezondheidszorg

Gedrag en maatschappij

Taal en cultuur

Recht en openbare orde

Natuurwetenschappen

\section{Toelichting}

Vraag in de enquête:

- Heeft $u$ in de afgelopen vier weken iets gedaan om aan ander werk te komen? 
Tabel A3.14

Deelname aan een cursus of bedrijfsopleiding door werkende schoolverlaters

BOL niveau $1 / 2$ totaal

Landbouw

Techniek

Economie

Gezondheidszorg

BOL niveau $3 / 4$ totaal

Landbouw

Techniek

Economie

Gezondheidszorg

Gedrag en maatschappij

HBO totaal

Landbouw

Onderwijs

Techniek

Economie

Gezondheidszorg

Gedrag en maatschappij

Kunst en cultuur

WO totaal

Landbouw

Techniek

Economie

Gezondheidszorg

Gedrag en maatschappij

Taal en cultuur

Recht en openbare orde

Natuurwetenschappen

\section{Toelichting}

- Voor het WO hebben de resultaten betrekking op 9 universiteiten.

Vraag in de enquête:

- Heeft u na het verlaten van de [...] opleiding een cursus of bedriffsopleiding gevolgd? 
Tabel A3.15

Belangrijkste cursussen of bedrijfsopleidingen waaraan werkende schoolverlaters deelnemen

\section{BOL niveau 1/2 landbouw}

Detailhandel (incl. middenstandsdiploma)

BB, bedrijfszelfbescherming $\quad 22$

Landbouw 14

Werktuigbouwkunde $\quad 14$

Techniek

BOL niveau $1 / 2$ techniek

BB, bedrijfszelfbescherming

$\begin{array}{ll}\text { Procestechniek } & 15\end{array}$

Techniek 13

$\begin{array}{ll}\text { Elektrotechniek } & 7 \\ \text { Wect, ralvervor } & 73\end{array}$

Weg-, railvervoer $\quad 7$

\begin{tabular}{ll} 
Commercieel & 7 \\
\hline
\end{tabular}

Marketing, reclame 6

Recht 6

BOL niveau $1 / 2$ economie

Bedrijfsadministratie, accountancy 15

Computer en informatica $\quad 12$

Verzekeringswezen 9

BB, bedrijfszelfbescherming $\quad 9$

Administratief

Communicatieve vaardigheden $\quad 6$

Bedrijfskunde, management, efficiency $\quad 5$

Horeca

BOL niveau $1 / 2$ gezondheidszorg

Uiterlijke verzorging

Computer en informatica

16

Bedrijfstechniek, technische bedrijfsvoe $\quad 10$

Gezondheidszorg 9

Gedrag en maatschappij $\quad 9$

Communicatieve vaardigheden $\quad 9$

BOL niveau 3/4 landbouw

$\mathrm{BB}$, bedrijfszelfbescherming

Computer en informatica

Bedrijfskunde, management, efficiency

Tuinbouw

BOL niveau $3 / 4$ techniek

Computer en informatica

Techniek 15

BB, bedrijfszelfbescherming $\quad 15$

Bouwkunde $\quad 7$

Werktuigbouwkunde $\quad 6$

Elektrotechniek

Bedrijfskunde, management, efficiency $\quad 5$ 
Tabel A3.15 (vervolg)

Belangrijkste cursussen of bedrijfsopleidingen waaraan werkende schoolverlaters deelnemen

BOL niveau 3/4 economie

Verzekeringswezen

Commerciee

Bedrijfskunde, management, efficiency

Bedrijfsadministratie, accountancy

Geld- en bankzaken

Computer en informatica

BOL niveau $3 / 4$ gezondheidszorg

Geneeskunde

Gezondheidszorg

Verpleging

Communicatieve vaardigheden

$\mathrm{BB}$, bedrijfszelfbescherming

Farmacie

BOL niveau $3 / 4$ gedrag en maatschappij

$\mathrm{BB}$, bedrijfszelfbescherming

Gezondheidszorg

Computer en informatica

Gedrag en maatschappij

Verpleging

Kinderverzorging

HBO landbouw

Bedrijfsadministratie, accountancy

Commercieel

Geld- en bankzaken

Computer en informatica

Bedrijfskunde, management, efficiency

$\mathrm{BB}$, bedrijfszelfbescherming

HBO onderwijs

Pedagog.-didactische cursussen voor leer

Computer en informatica

Communicatieve vaardigheden

Algemeen

$\mathrm{BB}$, bedrijfszelfbescherming

HBO techniek

Computer en informatica

Bedrijfskunde, management, efficiency

Bouwkunde

BB, bedrijfszelfbescherming 
Tabel A3.15 (vervolg)

Belangrijkste cursussen of bedrijfsopleidingen waaraan werkende schoolverlaters deelnemen

HBO economie

Computer en informatica 16

Geld- en bankzaken $\quad 11$

Bedrijfskunde, management, efficiency 19

$\begin{array}{ll}\text { Verzekeringswezen } & 7\end{array}$

Bedrijfsadministratie, accountancy $\quad 6$

Commercieel 6

Communicatieve vaardigheden $\quad 6$

Marketing, reclame $\quad 5$

HBO gezondheidszorg

Verpleging

Fysiotherapie, bewegingsleer $\quad 13$

Geneeskunde $\quad 8$

$\begin{array}{ll}\text { Gezondheidszorg } & 7\end{array}$

Therapie 6

HBO gedrag en maatschappij

Communicatieve vaardigheden $\quad 10$

\begin{tabular}{ll} 
Maatschappelijk werk & 8 \\
\hline
\end{tabular}

Computer en informatica $\quad 7$

$\begin{array}{ll}\text { Bedrijfskunde, management, efficiency } & 7\end{array}$

Personeelswerk

HBO kunst en cultuur

Computer en informatica $\quad 19$

Grafische techniek 13

Bedrijfskunde, management, efficiency 13

Theater $\quad 8$

WO landbouw

Bedrijfskunde, management, efficiency 17

Communicatieve vaardigheden 16

Computer en informatica 12

WO techniek

Computer en informatica $\quad 18$

$\begin{array}{ll}\text { Bedrijfskunde, management, efficiency } & 17\end{array}$

Communicatieve vaardigheden $\quad 9$

Techniek

Bouwkunde $\quad 6$

WO economie

Geld- en bankzaken

Communicatieve vaardigheden 14

Bedrijfskunde, management, efficiency 13

Computer en informatica $\quad 12$

Verzekeringswezen $\quad 5$ 
Tabel A3.15 (vervolg)

Belangrijkste cursussen of bedrijfsopleidingen waaraan werkende schoolverlaters deelnemen

\section{WO gezondheidszorg}

Geneeskunde

Gezondheidszorg

Bedrijfskunde, management, efficiency

Verpleging

WO gedrag en maatschappij

Bedrijfskunde, management, efficiency 17

Communicatieve vaardigheden 12

Computer en informatica $\quad 10$

Communicatie

WO taal en cultuur

Computer en informatica $\quad 17$

Bedrijfskunde, management, efficiency

$\begin{array}{lr}\text { Marketing, reclame } & 7\end{array}$

Communicatieve vaardigheden $\quad 7$

WO recht en openbare orde

Belastingen

Geld- en bankzaken

Recht en openbare orde

Bedrijfskunde, management, efficiency

Verzekeringswezen

WO natuurwetenschappen

Computer en informatica

Communicatieve vaardigheden $\quad 11$

Bedrijfskunde, management, efficiency 9

$\begin{array}{ll}\text { Geneeskunde } & 6\end{array}$

\section{Toelichting}

- Voor het WO hebben de resultaten betrekking op 9 universiteiten.

- In de tabel zijn alleen die cursussen en bedrijfsopleidingen opgenomen waaraan ten minste $5 \%$ van de schoolverlaters deelneemt. 
Tabel A4.1

Enkele kernindicatoren

\begin{tabular}{|c|c|c|c|c|c|c|c|c|c|}
\hline \multirow[t]{2}{*}{ Opleidingssector } & \multirow[t]{2}{*}{$\begin{array}{r}\text { opgehoogd } \\
\text { aantal } \\
\text { populatie }\end{array}$} & \multirow{2}{*}{$\begin{array}{r}\text { verder } \\
\text { leren } \\
\\
\\
\% \\
\end{array}$} & \multirow{2}{*}{$\begin{array}{r}\text { zelfde } \\
\text { opleiding } \\
\text { opnieuw } \\
\text { kiezen } \\
\% \\
\end{array}$} & \multirow{2}{*}{$\begin{array}{r}\text { werk- } \\
\text { loosheid } \\
\\
\% \\
\end{array}$} & \multirow{2}{*}{$\begin{array}{r}\text { intrede } \\
\text { werk- } \\
\text { loosheid } \\
\text { maanden }\end{array}$} & \multirow{2}{*}{$\begin{array}{r}\text { flexibele } \\
\text { aanstelling } \\
\\
\% \\
\end{array}$} & \multirow{2}{*}{$\begin{array}{r}\text { bruto } \\
\text { uurloon } \\
\\
\text { fl. } \\
\end{array}$} & \multirow{2}{*}{$\begin{array}{r}\text { minimaal } \\
\text { eigen } \\
\text { niveau } \\
\\
\% \\
\end{array}$} & \multirow{2}{*}{$\begin{array}{r}\text { eigen/ } \\
\text { verwante } \\
\text { richting } \\
\% \\
\%\end{array}$} \\
\hline & & & & & & & & & \\
\hline VBO totaal & 41.244 & 90 & $\mathbf{x}$ & 4 & 0,5 & 11 & 9,28 & 69 & 53 \\
\hline IVBO & 4.716 & 82 & $\mathrm{x}$ & 12 & 0,6 & 12 & 9,50 & 57 & 37 \\
\hline Landbouw & 3.309 & 92 & $\mathrm{x}$ & 10 & 0,4 & 18 & 8,23 & 74 & 46 \\
\hline Techniek & 15.805 & 88 & $\mathrm{x}$ & 2 & 0,5 & 8 & 9,40 & 67 & 65 \\
\hline Economie & 7.625 & 91 & $x$ & 7 & 0,3 & 22 & 9,05 & 70 & 25 \\
\hline Gezondheidszorg & 9.789 & 94 & $x$ & 1 & 0,6 & 8 & 9,28 & 80 & 49 \\
\hline BOL niveau $1 / 2$ totaal & 11.291 & 47 & 70 & 4 & 0,8 & 21 & 13,48 & 53 & 55 \\
\hline Landbouw & 308 & 25 & 76 & 8 & 0,7 & 11 & 11,27 & 52 & 65 \\
\hline Techniek & 2.016 & 54 & 71 & 2 & 0,3 & 14 & 13,76 & 53 & 58 \\
\hline Economie & 7.082 & 41 & 68 & 5 & 1,0 & 24 & 13,40 & 54 & 50 \\
\hline Gezondheidszorg & 1.885 & 65 & 75 & 2 & 0,5 & 21 & 13,87 & 51 & 68 \\
\hline BOL niveau $3 / 4$ totaal & 40.168 & 49 & 81 & 2 & 0,3 & 16 & 17,75 & 79 & 74 \\
\hline Landbouw & 3.347 & 33 & 84 & 2 & 0,4 & 18 & 15,76 & 67 & 65 \\
\hline Techniek & 9.977 & 47 & 84 & 2 & 0,3 & 13 & 19,65 & 84 & 81 \\
\hline Economie & 13.085 & 52 & 76 & 2 & 0,2 & 16 & 16,65 & 79 & 66 \\
\hline Gezondheidszorg & 6.179 & 48 & 77 & 1 & 0,4 & 14 & 17,04 & 77 & 83 \\
\hline Gedrag en maatschappij & 7.580 & 53 & 86 & 3 & 0,4 & 22 & 18,66 & 80 & 75 \\
\hline
\end{tabular}


Tabel A4. 1 (vervolg)

Enkele kernindicatoren

\begin{tabular}{|c|c|c|c|c|c|c|c|c|c|}
\hline \multirow[t]{2}{*}{ Opleidingssector } & \multirow[t]{2}{*}{$\begin{array}{r}\text { opgehoogd } \\
\text { aantal } \\
\text { populatie }\end{array}$} & \multirow{2}{*}{$\begin{array}{r}\text { verder } \\
\text { leren } \\
\\
\\
\% \\
\end{array}$} & \multirow{2}{*}{$\begin{array}{r}\text { zelfde } \\
\text { opleiding } \\
\text { opnieuw } \\
\text { kiezen } \\
\% \\
\end{array}$} & \multirow{2}{*}{$\begin{array}{r}\text { werk- } \\
\text { loosheid } \\
\% \\
\%\end{array}$} & \multirow{2}{*}{$\begin{array}{r}\text { intrede } \\
\text { werk- } \\
\text { loosheid } \\
\text { maanden } \\
\end{array}$} & \multirow{2}{*}{$\begin{array}{r}\text { flexibele } \\
\text { aanstelling } \\
\\
\% \\
\end{array}$} & \multirow{2}{*}{$\begin{array}{r}\text { bruto } \\
\text { uurloon } \\
\\
\mathrm{fl} .\end{array}$} & \multirow{2}{*}{$\begin{array}{r}\text { minimaal } \\
\text { eigen } \\
\text { niveau }\end{array}$} & \multirow{2}{*}{$\begin{array}{r}\text { eigen/ } \\
\text { verwante } \\
\text { richting } \\
\% \\
\%\end{array}$} \\
\hline & & & & & & & & & \\
\hline BBL niveau $1 / 2$ totaal & 12.272 & 43 & 75 & 1 & 0,2 & 6 & 16,71 & 44 & 56 \\
\hline Techniek & 7.514 & 42 & 80 & 1 & 0,1 & 2 & 17,89 & 40 & 61 \\
\hline Economie & 3.663 & 51 & 66 & 1 & 0,4 & 8 & 14,28 & 41 & 43 \\
\hline Gezondheidszorg & 1.094 & 22 & 72 & 4 & 0,9 & 18 & 17,11 & 70 & 70 \\
\hline BBL niveau $3 / 4$ totaal & 14.025 & 21 & 82 & 0 & 0,2 & 5 & 21,46 & 59 & 77 \\
\hline Techniek & 4.722 & 30 & 86 & 0 & 0 & 2 & 22,44 & 38 & 75 \\
\hline Economie & 2.607 & 24 & 73 & 2 & 0,3 & 10 & 18,01 & 49 & 60 \\
\hline Gezondheidszorg & 5.583 & 14 & 83 & 0 & 0,1 & 4 & 22,80 & 78 & 86 \\
\hline Gedrag en maatschappij & 1.113 & 9 & 85 & 0 & 0,6 & 18 & 18,89 & 66 & 75 \\
\hline HBO totaal & 42.264 & 27 & 77 & 3 & 0,8 & 12 & 25,05 & 80 & 77 \\
\hline Landbouw & 1.693 & 26 & 77 & 2 & 0,8 & 18 & 23,18 & 75 & 78 \\
\hline Onderwijs & 6.783 & 28 & 83 & 3 & 0,6 & 13 & 27,08 & 89 & 87 \\
\hline Techniek & 9.208 & 27 & 79 & 2 & 0,8 & 9 & 24,89 & 85 & 80 \\
\hline Economie & 12.607 & 29 & 73 & 3 & 0,8 & 10 & 24,32 & 79 & 64 \\
\hline Gezondheidszorg & 3.953 & 23 & 80 & 3 & 0,8 & 13 & 26,55 & 82 & 93 \\
\hline Gedrag en maatschappij & 5.604 & 24 & 72 & 4 & 0,9 & 18 & 24,38 & 66 & 76 \\
\hline Kunst en cultuur & 2.416 & 21 & 87 & 11 & 2,1 & 19 & 23,93 & 67 & 76 \\
\hline
\end{tabular}


Tabel A4. 1 (vervolg)

Enkele kernindicatoren

\begin{tabular}{|c|c|c|c|c|c|c|c|c|c|}
\hline \multirow[t]{2}{*}{ Opleidingssector } & \multirow[t]{2}{*}{$\begin{array}{r}\text { opgehoogd } \\
\text { aantal } \\
\text { populatie }\end{array}$} & \multirow{2}{*}{$\begin{array}{r}\text { verder } \\
\text { leren } \\
\\
\\
\% \\
\end{array}$} & \multirow{2}{*}{$\begin{array}{r}\text { zelfde } \\
\text { opleiding } \\
\text { opnieuw } \\
\text { kiezen } \\
\% \\
\%\end{array}$} & \multirow{2}{*}{$\begin{array}{r}\text { werk- } \\
\text { loosheid } \\
\\
\% \\
\end{array}$} & \multirow{2}{*}{$\begin{array}{r}\text { intrede } \\
\text { werk- } \\
\text { loosheid } \\
\% \\
\end{array}$} & \multirow{2}{*}{$\begin{array}{r}\text { flexibele } \\
\text { aanstelling } \\
\\
\% \\
\end{array}$} & \multirow{2}{*}{$\begin{array}{r}\text { bruto } \\
\text { uurloon } \\
\\
\text { fl. }\end{array}$} & \multirow{2}{*}{$\begin{array}{r}\text { minimaal } \\
\text { eigen } \\
\text { niveau } \\
\\
\% \\
\end{array}$} & \multirow{2}{*}{$\begin{array}{r}\text { eigen/ } \\
\text { verwante } \\
\text { richting } \\
\% \\
\%\end{array}$} \\
\hline & & & & & & & & & \\
\hline WO totaal & 19.711 & 26 & 82 & 2 & 0,9 & 9 & 29,18 & 66 & 71 \\
\hline Landbouw & 624 & 22 & 75 & 5 & 1,6 & 16 & 24,90 & 65 & 75 \\
\hline Techniek & 2.893 & 18 & 85 & 0 & 0,9 & 4 & 29,40 & 69 & 75 \\
\hline Economie & 3.096 & 24 & 86 & 1 & 0,7 & 3 & 30,47 & 62 & 71 \\
\hline Gezondheidszorg & 2.493 & 37 & 83 & 2 & 0,6 & 8 & 32,02 & 92 & 92 \\
\hline Gedrag en maatschappij & 4.068 & 18 & 79 & 3 & 1,0 & 13 & 29,58 & 56 & 62 \\
\hline Taal en cultuur & 2.651 & 27 & 77 & 4 & 1,2 & 20 & 27,22 & 40 & 44 \\
\hline Recht en openbare orde & 2.310 & 21 & 85 & 1 & 0,8 & 5 & 29,02 & 81 & 80 \\
\hline Natuurwetenschappen & 1.575 & 50 & 80 & 2 & 0,9 & 10 & 25,60 & 75 & 79 \\
\hline Totaal & 278.489 & 65 & 79 & 3 & 0,6 & 12 & 20,54 & 64 & 69 \\
\hline
\end{tabular}

\section{Toelichting}

- Deze tabel geeft een samenvattend beeld. Zie ook de tabellen C2, A2.1, A1.4, A3.1, A3.3, A3.8, A3.9 en A3.10. 
B. Tabellen per opleidingsrichting 



\section{Inhoud}

1 Bestemming van schoolverlaters

B1.1 De uitstroom van schoolverlaters verbijzonderd naar geslacht, etniciteit en gemiddelde leeftijd op moment van enquête

B1.2 Vooropleiding van schoolverlaters

B1.3 Bestemming van schoolverlaters

B1.4 Gevolgde opleiding opnieuw kiezen?

\section{Doorstroom naar vervolgonderwijs}

B2.1 Doorstroom van schoolverlaters naar vervolgonderwijs

B2.2 Belangrijkste opleidingen van schoolverlaters die een voltijd vervolgopleiding zijn gaan volgen

B2.3 Oordeel van schoolverlaters over de aansluiting van de afgesloten opleiding met de voltijd vervolgopleiding

B2.4 Doorstroom van schoolverlaters naar de beroepsbegeleidende leerweg

3 Intrede op de arbeidsmarkt

B3.1 Werkloosheid en gemiddelde intredewerkloosheid van schoolverlaters die zich aanbieden op de arbeidsmarkt

B3.2 Aard van het dienstverband van werkende schoolverlaters

B3.3 Percentage werkende schoolverlaters met een flexibele aanstelling

B3.4 Wijze van verkrijgen van een baan

B3.5 Belangrijkste bedrijfsgroepen waarin schoolverlaters werkzaam zijn

B3.6 Belangrijkste beroepsgroepen waarin schoolverlaters werkzaam zijn

B3.7 Grootte van de organisatie waarin schoolverlaters werkzaam zijn

B3.8 Beloning van werkende schoolverlaters

B3.9 Vereist opleidingsniveau voor de huidige functie volgens de werkgever

B3.10 Vereiste opleidingsrichting voor de huidige functie volgens de werkgever

B3.11 Gewenste en feitelijke wekelijkse arbeidsduur van werkende schoolverlaters

B3.12 Oordeel van de werkende schoolverlaters over de aansluiting tussen de afgesloten opleiding en de huidige functie

B3.13 Percentage werkende schoolverlaters dat op zoek is naar een andere baan

B3.14 Deelname aan een cursus of bedrijfsopleiding door werkende schoolverlaters

B3.15 Belangrijkste cursussen of bedrijfsopleidingen waaraan werkende schoolverlaters deelnemen

\section{Kernindicatoren}

B4.1 Enkele kernindicatoren 
Tabel B1.1

De uitstroom van schoolverlaters verbijzonderd naar geslacht, etniciteit en gemiddelde leeftijd op moment van enquête

\begin{tabular}{lrrr}
\hline van enquete & vrouw & $\begin{array}{r}\text { alloch- } \\
\text { toon } \\
\text { Opleidingsrichting }\end{array}$ & $\begin{array}{r}\text { gemid. } \\
\text { leeftijd }\end{array}$ \\
\hline
\end{tabular}

VBO

IVBO Landbouw en natuurlijke omgeving

IVBO Verzorging

Landbouw en natuurlijke omgeving

Bouwtechniek

Mechanische techniek

Elektrotechniek

Motorvoertuigentechniek

Consumptieve techniek

Administratie

Verkoop

Handel

Verzorging

Uiterlijke verzorging

Mode en kleding

$\begin{array}{rrr}39 & 6 & 17,9 \\ 76 & 8 & 17,9 \\ 52 & 3 & 17,4 \\ 2 & 4 & 17,4 \\ 0 & 3 & 17,6 \\ 0 & 9 & 17,8 \\ 4 & 4 & 17,3 \\ 26 & 10 & 17,7 \\ 59 & 23 & 17,6 \\ 66 & 13 & 17,5 \\ 63 & 13 & 17,6 \\ 95 & 5 & 17,4 \\ 100 & 17 & 17,2 \\ 73 & 25 & 17,4\end{array}$

BOL niveau 1/2

BB Bloemschikken

BB Groene ruimte

BB Houtbewerking en woninginrichting

BB Motorvoertuigen

BB Energie- en informatietechniek

BB Bedrijfsadministratie

BB Beveiliging

BB Secretarieel

AB Detailhandel/ambulante handel

BB Detailhandel/ambulante handel

BB Horeca, instellingskeuken en contractcatering

BB Verpleging en verzorging

17,9

17,9

17,8

17,7

17,6

17,4

17,4

20,3

19,9

22,1

20,0

20,5

20,5

21,8

21,4

19,5

20,1

19,9

21,1

BOL niveau $3 / 4$

ZB Plantenteelt

ZB Veehouderij

ZB Bloemschikken

ZB Groene ruimte

KF Plantenteelt

KF Veehouderij

KF Levensmiddelentechnologie

KF Bloemschikken

KF Dierverzorging en veterinaire ondersteuning

KF Groene ruimte

KF Milieutoezicht

MKF Bouw

MKF Houtbewerking en woninginrichting

MKF Grond-, water- en wegenbouw

MKF Beschermings- en afwerkingstechnieken

MKF Reclame, presentatie en communicatie

MKF Fijnmechanische techniek

MKF Operationele techniek

MKF Werktuigbouwkunde

MKF Motorvoertuigen

MKF Energie- en informatietechniek

64
20,1

20,8 
Tabel B1.1 (vervolg)

De uitstroom van schoolverlaters verbijzonderd naar geslacht, etniciteit en gemiddelde leeftijd op moment van enquête

\begin{tabular}{lccc}
\hline Opleidingsrichting & vrouw & alloch- & gemid. \\
& $\%$ & toon & leeftijd \\
\hline
\end{tabular}

BOL niveau 3/4 (vervolg)

MKF Informatietechniek

MKF Scheepsbouwkundige (scheepsbouw)

MKF Grafische techniek, communicatie, audiovisueel

MKF Laboratoriumtechniek

MKF Procestechniek

MKF Scheepvaart

MKF Transport en logistiek

MKF Automatisering

MKF Bedrijfsadministratief

MKF Commercieel

MKF Economisch-juridisch

MKF Secretarieel

MKF Detailhandel/ambulante handel

MKF Horeca, instellingskeuken en contractcatering

MKF Toerisme, recreatie en reizen

MKF Assistenten gezondheidszorg

MKF Facilitaire dienstverlening

MKF Sport en bewegen

MKF Verpleging en verzorging

ZB Uiterlijke verzorging

MKF Sociaal-cultureel werker

MKF Sociaal-pedagogisch werk algemeen

MKF Sociaal-juridisch werk

$\begin{array}{rrr}5 & 0 & 22,6 \\ 0 & 0 & 23,1 \\ 40 & 7 & 22,7 \\ 49 & 2 & 22,2 \\ 13 & 0 & 22,1 \\ 5 & 3 & 23,2 \\ 71 & 15 & 22,4 \\ 14 & 19 & 26,0 \\ 52 & 8 & 21,1 \\ 50 & 9 & 21,3 \\ 51 & 9 & 21,0 \\ 99 & 7 & 20,9 \\ 47 & 9 & 21,1 \\ 52 & 5 & 22,5 \\ 90 & 7 & 22,0 \\ 98 & 11 & 21,0 \\ 69 & 6 & 21,3 \\ 37 & 4 & 21,9 \\ 94 & 5 & 21,4 \\ 100 & 7 & 20,9 \\ 80 & 17 & 22,5 \\ 93 & 5 & 22,3 \\ 84 & 26 & 24,1\end{array}$

BBL niveau $1 / 2$

BB Bouw

BB Beschermings- en afwerkingstechnieken

BB Constructie(bank)werken/(isolatie)plaatwerken/pijpenbew.

BB Machinebankwerken/verspanen

BB Energie- en informatietechniek

BB Wegvervoer

BB Secretarieel

BB Detailhandel/ambulante handel

BB Horeca, instellingskeuken en contractcatering

BB Facilitaire dienstverlening

BB Verpleging en verzorging

BBL niveau $3 / 4$

MKF Bouw

ZB Grond-, water- en wegenbouw

ZB Contructie(bank)werken/(isolatie)plaatwerken/pijpenbew.

MKF Motorvoertuigen

Specialist Energie- en informatietechniek

Specialist Installatie-, service- en onderhoudstechniek

MKF Procestechniek

MKF Automatisering

MKF Detailhandel/ambulante handel

MKF Horeca, instellingskeuken en contractcatering

MKF Verpleging en verzorging

ZB Uiterlijke verzorging

MKF Sociaal-pedagogisch werk

$\begin{array}{rrr}0 & 4 & 21,4 \\ 0 & 13 & 24,1 \\ 2 & 11 & 22,9 \\ 2 & 0 & 20,0 \\ 0 & 13 & 21,0 \\ 3 & 2 & 20,4 \\ 97 & 23 & 26,9 \\ 88 & 9 & 20,9 \\ 42 & 10 & 20,8 \\ 100 & 21 & 34,2 \\ 97 & 6 & 26,8\end{array}$

Zie ook toelichting bladzijde 5 
Tabel B1.2

Vooropleiding van schoolverlaters

\begin{tabular}{|c|c|c|c|c|c|c|c|c|}
\hline Opleidingsrichting & MAVO & HAVO & VWO & VBO & $\begin{array}{r}\mathrm{BOL} \\
\text { niv. } 1 / 2\end{array}$ & $\begin{array}{r}\text { BOL } \\
\text { niv. } 3 / 4\end{array}$ & BBL & overig \\
\hline & $\%$ & $\%$ & $\%$ & $\%$ & $\%$ & $\%$ & $\%$ & $\%$ \\
\hline
\end{tabular}

\section{BOL niveau $1 / 2$}

BB Bloemschikken

BB Groene ruimte

BB Houtbewerking en woninginrichting

BB Motorvoertuigen

BB Energie- en informatietechniek

BB Bedrijfsadministratie

BB Beveiliging

BB Secretarieel

AB Detailhandel/ambulante handel

BB Detailhandel/ambulante handel

BB Horeca, instellingskeuken en contractcatering

BB Verpleging en verzorging

0
24
24
27
28
39
61
39
6
15
24
6

5

\section{BOL niveau $3 / 4$}

ZB Plantenteelt

ZB Veehouderij

ZB Bloemschikken

ZB Groene ruimte

KF Plantenteelt

KF Veehouderij

KF Levensmiddelentechnologie

KF Bloemschikken

KF Dierverzorging en veterinaire ondersteuning

KF Groene ruimte

KF Milieutoezicht

MKF Bouw

5
0
7
0
0
0
5
0
0
0
0
1

$\begin{array}{ll}0 & 66 \\ 0 & 76 \\ 0 & 51 \\ 0 & 73 \\ 0 & 66 \\ 0 & 56 \\ 0 & 16 \\ 0 & 53 \\ 0 & 87 \\ 0 & 75 \\ 0 & 66 \\ 0 & 90\end{array}$

$5-13$

$\begin{array}{lrrrrrrr}21 & 0 & 0 & 73 & 2 & 4 & 0 & 0 \\ 27 & 0 & 0 & 71 & 0 & 3 & 0 & 0 \\ 27 & 0 & 0 & 64 & 0 & 7 & 0 & 2 \\ 28 & 0 & 0 & 57 & 11 & 5 & 0 & 0 \\ 57 & 11 & 1 & 25 & 1 & 5 & 0 & 0 \\ 54 & 8 & 0 & 33 & 1 & 4 & 0 & 1 \\ 71 & 19 & 0 & 5 & 0 & 5 & 0 & 0 \\ 60 & 19 & 0 & 20 & 0 & 1 & 0 & 0 \\ 41 & 45 & 0 & 14 & 0 & 0 & 0 & 0 \\ 63 & 14 & 1 & 17 & 1 & 3 & 0 & 0 \\ 91 & 8 & 0 & 1 & 0 & 0 & 0 & 0 \\ 54 & 14 & 0 & 28 & 1 & 1 & 0 & 1\end{array}$


Tabel B1.2 (vervolg)

Vooropleiding van schoolverlaters

\begin{tabular}{|c|c|c|c|c|c|c|c|c|}
\hline Opleidingsrichting & MAVO & HAVO & VWO & VBO & $\begin{array}{r}\mathrm{BOL} \\
\text { niv. } 1 / 2\end{array}$ & $\begin{array}{r}\text { BOL } \\
\text { niv. } 3 / 4\end{array}$ & BBL & overig \\
\hline & $\%$ & $\%$ & $\%$ & $\%$ & $\%$ & $\%$ & $\%$ & $\%$ \\
\hline
\end{tabular}

BOL niveau 3/4 (vervolg)

MKF Houtbewerking en woninginrichting

MKF Grond-, water- en wegenbouw

MKF Beschermings- en afwerkingstechnieken

MKF Reclame, presentatie en communicatie

MKF Fijnmechanische techniek

MKF Operationele techniek

MKF Werktuigbouwkunde

MKF Motorvoertuigen

MKF Energie- en informatietechniek

MKF Informatietechniek

MKF Scheepsbouwkundige (scheepsbouw)

MKF Grafische techniek, communicatie, audiovisueel

MKF Laboratoriumtechniek

MKF Procestechniek

MKF Scheepvaart

MKF Transport en logistiek

MKF Automatisering

MKF Bedrijfsadministratief

MKF Commercieel

MKF Economisch-juridisch

MKF Secretarieel

MKF Detailhandel/ambulante hande

MKF Horeca, instellingskeuken en contractcatering

MKF Toerisme, recreatie en reizen

$\begin{array}{rr}47 & 15 \\ 53 & 13 \\ 35 & 45 \\ 65 & 22 \\ 55 & 26 \\ 56 & 11 \\ 61 & 12 \\ 57 & 13 \\ 40 & 9 \\ 63 & 19 \\ 35 & 31 \\ 44 & 32 \\ 75 & 16 \\ 93 & 1 \\ 50 & 7 \\ 42 & 20 \\ 25 & 48 \\ 53 & 29 \\ 73 & 17 \\ 70 & 8 \\ 70 & 20 \\ 70 & 7 \\ 49 & 47 \\ 65 & 31 \\ 68 & 16\end{array}$

$\begin{array}{rrr}15 & 5 & 26 \\ 13 & 0 & 16 \\ 45 & 5 & 15 \\ 22 & 0 & 7 \\ 26 & 0 & 16 \\ 11 & 0 & 22 \\ 12 & 0 & 19 \\ 13 & 0 & 19 \\ 9 & 0 & 40 \\ 19 & 0 & 9 \\ 31 & 0 & 14 \\ 32 & 2 & 14 \\ 16 & 0 & 5 \\ 1 & 0 & 6 \\ 7 & 0 & 36 \\ 20 & 12 & 24 \\ 48 & 0 & 0 \\ 29 & 1 & 9 \\ 17 & 0 & 5 \\ 8 & 0 & 13 \\ 20 & 0 & 5 \\ 7 & 0 & 15 \\ 47 & 3 & 2 \\ 31 & 0 & 1 \\ 16 & 1 & 11\end{array}$

0
3
0
0
0
6
1
3
5
6
0
0
4
0
2
0
5
5
4
9
3
6
0
1
2

MKF Assistenten gezondheidszorg 
Tabel B1.2 (vervolg)

Vooropleiding van schoolverlaters

\begin{tabular}{|c|c|c|c|c|c|c|c|c|}
\hline Opleidingsrichting & MAVO & HAVO & VWO & VBO & $\begin{array}{r}\mathrm{BOL} \\
\text { niv. } 1 / 2\end{array}$ & $\begin{array}{r}\text { BOL } \\
\text { niv. } 3 / 4\end{array}$ & BBL & overig \\
\hline & $\%$ & $\%$ & $\%$ & $\%$ & $\%$ & $\%$ & $\%$ & $\%$ \\
\hline
\end{tabular}

BOL niveau 3/4 (vervolg)

MKF Facilitaire dienstverlening

MKF Sport en bewegen

MKF Verpleging en verzorging

ZB Uiterlijke verzorging

MKF Sociaal-cultureel werker

MKF Sociaal-pedagogisch werk algemeen

MKF Sociaal-juridisch werk

$\begin{array}{rr}58 & 9 \\ 70 & 21 \\ 51 & 3 \\ 64 & 1 \\ 59 & 1 \\ 61 & 6 \\ 60 & 9\end{array}$

\section{BBL niveau $1 / 2$}

BB Bouw

BB Constructie(bank)werken/(isolatie)plaatwerken/pijpenbew.

BB Machinebankwerken/verspanen

BB Wegvervoer

BB Secretarieel

BB Detailhandel/ambulante handel

BB Horeca, instellingskeuken en contractcatering

BB Facilitaire dienstverlening

BB Verpleging en verzorging

$\begin{array}{rrrrrrrr}7 & 6 & 0 & 83 & 3 & 1 & 0 & 0 \\ 23 & 0 & 0 & 53 & 12 & 7 & 2 & 4 \\ 19 & 0 & 0 & 81 & 0 & 0 & 0 & 0 \\ 27 & 3 & 0 & 63 & 5 & 2 & 0 & 0 \\ 21 & 0 & 0 & 23 & 14 & 42 & 0 & 0 \\ 28 & 0 & 0 & 62 & 3 & 3 & 3 & 0 \\ 32 & 0 & 3 & 39 & 6 & 13 & 6 & 0 \\ 31 & 9 & 0 & 37 & 5 & 14 & 0 & 5 \\ 22 & 3 & 0 & 42 & 3 & 20 & 10 & 1\end{array}$

\section{BBL niveau 3/4}

MKF Bouw

ZB Grond-, water- en wegenbouw

MKF Motorvoertuigen

Specialist Energie- en informatietechniek

Specialist Installatie-, service- en onderhoudstechniek

MKF Procestechniek

\begin{tabular}{|c|c|c|c|c|c|c|}
\hline 13 & 1 & 0 & 53 & 9 & 7 & 16 \\
\hline 26 & 0 & 0 & 48 & 4 & 9 & 12 \\
\hline 9 & 2 & 4 & 32 & 11 & 22 & 18 \\
\hline 5 & 0 & 5 & 32 & 17 & 33 & 7 \\
\hline 2 & 0 & 0 & 21 & 11 & 7 & 41 \\
\hline 21 & 0 & 0 & 47 & 11 & 16 & 5 \\
\hline
\end{tabular}


Tabel B1.2 (vervolg)

Vooropleiding van schoolverlaters

\begin{tabular}{|c|c|c|c|c|c|c|c|c|}
\hline \multirow[t]{2}{*}{ Opleidingsrichting } & MAVO & HAVO & VWO & VBO & $\begin{array}{r}\mathrm{BOL} \\
\text { niv. } 1 / 2\end{array}$ & $\begin{array}{r}\text { BOL } \\
\text { niv. } 3 / 4\end{array}$ & BBL & overig \\
\hline & $\%$ & $\%$ & $\%$ & $\%$ & $\%$ & $\%$ & $\%$ & $\%$ \\
\hline \multicolumn{9}{|l|}{ BBL niveau 3/4 (vervolg) } \\
\hline MKF Automatisering & 24 & 25 & 15 & 0 & 12 & 18 & 0 & 6 \\
\hline MKF Detailhandel/ambulante handel & 46 & 4 & 0 & 30 & 3 & 11 & 6 & 0 \\
\hline MKF Horeca, instellingskeuken en contractcatering & 26 & 0 & 3 & 35 & 28 & 5 & 2 & 0 \\
\hline MKF Verpleging en verzorging & 21 & 16 & 4 & 3 & 0 & 36 & 11 & 11 \\
\hline ZB Uiterlijke verzorging & 41 & 0 & 0 & 47 & 6 & 6 & 0 & 0 \\
\hline MKF Sociaal-pedagogisch werk & 31 & 5 & 0 & 40 & 2 & 14 & 0 & 7 \\
\hline
\end{tabular}


Tabel B1.3

Bestemming van schoolverlaters

\begin{tabular}{|c|c|c|c|c|c|}
\hline \multirow[t]{2}{*}{ Opleidingsrichting } & studie & BBL & $\begin{array}{r}\text { betaald } \\
\text { werk }\end{array}$ & $\begin{array}{r}\text { werk- } \\
\text { loos }\end{array}$ & anders \\
\hline & $\%$ & $\%$ & $\%$ & $\%$ & $\%$ \\
\hline \multicolumn{6}{|l|}{ VBO } \\
\hline IVBO Landbouw en natuurlijke omgeving & 46 & 20 & 28 & 3 & 2 \\
\hline IVBO Verzorging & 49 & 17 & 10 & 0 & 24 \\
\hline Landbouw en natuurlijke omgeving & 65 & 15 & 17 & 1 & 2 \\
\hline Bouwtechniek & 36 & 26 & 37 & 0 & 1 \\
\hline Mechanische techniek & 31 & 34 & 22 & 2 & 12 \\
\hline Elektrotechniek & 51 & 14 & 32 & 1 & 2 \\
\hline Motorvoertuigentechniek & 24 & 24 & 52 & 0 & 0 \\
\hline Consumptieve techniek & 23 & 26 & 44 & 3 & 5 \\
\hline Administratie & 67 & 9 & 19 & 3 & 2 \\
\hline Verkoop & 52 & 9 & 33 & 2 & 4 \\
\hline Handel & 72 & 11 & 6 & 0 & 10 \\
\hline Verzorging & 68 & 16 & 16 & 0 & 1 \\
\hline Uiterlijke verzorging & 45 & 17 & 34 & 3 & 0 \\
\hline Mode en kleding & 59 & 3 & 38 & 0 & 0 \\
\hline
\end{tabular}

BOL niveau $1 / 2$

BB Bloemschikken

BB Groene ruimte

BB Houtbewerking en woninginrichting

BB Motorvoertuigen

BB Energie- en informatietechniek

BB Bedrijfsadministratie

BB Beveiliging

BB Secretarieel

$A B$ Detailhandel/ambulante handel

BB Detailhandel/ambulante handel

BB Horeca, instellingskeuken en contractcatering

BB Verpleging en verzorging

BOL niveau $3 / 4$

ZB Plantenteelt

ZB Veehouderij

ZB Bloemschikken

ZB Groene ruimte

KF Plantenteelt

KF Veehouderij

KF Levensmiddelentechnologie

KF Bloemschikken

KF Dierverzorging en veterinaire ondersteuning

KF Groene ruimte

KF Milieutoezicht

MKF Bouw

MKF Houtbewerking en woninginichting

MKF Grond-, water- en wegenbouw

MKF Beschermings- en afwerkingstechnieken

MKF Reclame, presentatie en communicatie

MKF Fijnmechanische techniek

MKF Operationele techniek

MKF Werktuigbouwkunde

MKF Motorvoertuigen

MKF Energie- en informatietechniek

$\begin{array}{rrrrr}6 & 15 & 70 & 9 & 0 \\ 27 & 0 & 73 & 0 & 0 \\ 9 & 0 & 86 & 0 & 5 \\ 21 & 14 & 65 & 0 & 0 \\ 25 & 19 & 56 & 0 & 0 \\ 32 & 3 & 61 & 1 & 3 \\ 18 & 4 & 78 & 0 & 0 \\ 23 & 1 & 67 & 7 & 3 \\ 30 & 0 & 70 & 0 & 0 \\ 13 & 7 & 72 & 3 & 4 \\ 22 & 16 & 63 & 0 & 0 \\ 25 & 23 & 48 & 1 & 3\end{array}$

70 
Tabel B1.3 (vervolg)

Bestemming van schoolverlaters

\begin{tabular}{|c|c|c|c|c|c|}
\hline \multirow[t]{2}{*}{ Opleidingsrichting } & \multirow{2}{*}{$\begin{array}{r}\text { studie } \\
\\
\% \\
\end{array}$} & \multirow{2}{*}{$\begin{array}{r}\text { BBL } \\
\% \\
\end{array}$} & \multirow{2}{*}{$\begin{array}{r}\text { betaald } \\
\text { werk } \\
\% \\
\end{array}$} & \multirow{2}{*}{$\begin{array}{r}\text { werk- } \\
\text { loos } \\
\% \\
\end{array}$} & \multirow{2}{*}{$\begin{array}{r}\text { anders } \\
\% \\
\end{array}$} \\
\hline & & & & & \\
\hline \multicolumn{6}{|l|}{ BOL niveau $3 / 4$ (vervolg) } \\
\hline MKF Informatietechniek & 47 & 0 & 53 & 0 & 0 \\
\hline MKF Scheepsbouwkundige (scheepsbouw) & 31 & 0 & 65 & 0 & 5 \\
\hline MKF Grafische techniek, communicatie, audiovisueel & 24 & 2 & 71 & 1 & 2 \\
\hline MKF Laboratoriumtechniek & 44 & 0 & 52 & 3 & 1 \\
\hline MKF Procestechniek & 49 & 0 & 51 & 0 & 0 \\
\hline MKF Scheepvaart & 27 & 1 & 68 & 3 & 1 \\
\hline MKF Transport en logistiek & 18 & 0 & 82 & 0 & 0 \\
\hline MKF Automatisering & 16 & 0 & 78 & 0 & 5 \\
\hline MKF Bedrijfsadministratief & 50 & 2 & 46 & 0 & 2 \\
\hline MKF Commercieel & 42 & 1 & 54 & 0 & 2 \\
\hline MKF Economisch-juridisch & 58 & 1 & 36 & 1 & 3 \\
\hline MKF Secretarieel & 22 & 2 & 72 & 2 & 2 \\
\hline MKF Detailhandel/ambulante handel & 43 & 1 & 53 & 1 & 2 \\
\hline MKF Horeca, instellingskeuken en contractcatering & 31 & 2 & 66 & 1 & 0 \\
\hline MKF Toerisme, recreatie en reizen & 32 & 1 & 65 & 1 & 1 \\
\hline MKF Assistenten gezondheidszorg & 15 & 3 & 80 & 1 & 2 \\
\hline MKF Facilitaire dienstverlening & 25 & 8 & 61 & 0 & 6 \\
\hline MKF Sport en bewegen & 45 & 1 & 51 & 1 & 2 \\
\hline MKF Verpleging en verzorging & 28 & 12 & 56 & 1 & 3 \\
\hline ZB Uiterlijke verzorging & 12 & 0 & 82 & 1 & 5 \\
\hline MKF Sociaal-cultureel werker & 38 & 0 & 59 & 2 & 0 \\
\hline MKF Sociaal-pedagogisch werk algemeen & 38 & 3 & 56 & 1 & 2 \\
\hline MKF Sociaal-juridisch werk & 46 & 2 & 47 & 2 & 3 \\
\hline \multicolumn{6}{|l|}{ BBL niveau $1 / 2$} \\
\hline BB Bouw & 0 & 33 & 66 & 0 & 1 \\
\hline BB Beschermings- en afwerkingstechnieken & 0 & 7 & 93 & 0 & 0 \\
\hline BB Constructie(bank)werken/(isolatie)plaatwerken/pijpenbew. & 2 & 10 & 82 & 2 & 5 \\
\hline BB Machinebankwerken/verspanen & 0 & 11 & 83 & 0 & 6 \\
\hline BB Energie- en informatietechniek & 0 & 19 & 81 & 0 & 0 \\
\hline BB Wegvervoer & 2 & 9 & 89 & 0 & 0 \\
\hline BB Secretarieel & 0 & 11 & 73 & 7 & 9 \\
\hline BB Detailhandel/ambulante handel & 3 & 18 & 76 & 0 & 3 \\
\hline BB Horeca, instellingskeuken en contractcatering & 3 & 40 & 57 & 0 & 0 \\
\hline BB Facilitaire dienstverlening & 0 & 0 & 95 & 0 & 5 \\
\hline BB Verpleging en verzorging & 8 & 4 & 80 & 4 & 3 \\
\hline \multicolumn{6}{|l|}{ BBL niveau $3 / 4$} \\
\hline MKF Bouw & 2 & 2 & 92 & 0 & 4 \\
\hline ZB Grond-, water- en wegenbouw & 0 & 0 & 100 & 0 & 0 \\
\hline ZB Contructie(bank)werken/(isolatie)plaatwerken/pijpenbew. & 0 & 7 & 93 & 0 & 0 \\
\hline MKF Motorvoertuigen & 4 & 7 & 89 & 0 & 0 \\
\hline Specialist Energie- en informatietechniek & 0 & 5 & 95 & 0 & 0 \\
\hline Specialist Installatie-, service- en onderhoudstechniek & 0 & 3 & 97 & 0 & 0 \\
\hline MKF Procestechniek & 0 & 0 & 95 & 0 & 5 \\
\hline MKF Automatisering & 6 & 0 & 83 & 12 & 0 \\
\hline MKF Detailhandel/ambulante handel & 3 & 5 & 92 & 0 & 0 \\
\hline MKF Horeca, instellingskeuken en contractcatering & 4 & 4 & 86 & 0 & 5 \\
\hline MKF Verpleging en verzorging & 0 & 2 & 93 & 1 & 4 \\
\hline ZB Uiterlijke verzorging & 17 & 0 & 78 & 0 & 6 \\
\hline MKF Sociaal-pedagogisch werk & 2 & 4 & 92 & 0 & 2 \\
\hline
\end{tabular}


Tabel B1.4

Gevolgde opleiding opnieuw kiezen?

Opleidingsrichting

$\begin{array}{rrr}\begin{array}{r}\text { zelfde } \\ \text { opleiding }\end{array} \quad \begin{array}{r}\text { andere } \\ \text { opleiding }\end{array} & \begin{array}{r}\text { geen } \\ \text { andere } \\ \text { opleiding }\end{array}\end{array}$

BOL niveau $1 / 2$

BB Bloemschikken

BB Groene ruimte

BB Houtbewerking en woninginrichting

BB Motorvoertuigen

BB Energie- en informatietechniek

BB Bedrijfsadministratie

BB Beveiliging

BB Secretarieel

AB Detailhandel/ambulante handel

BB Detailhandel/ambulante handel

BB Horeca, instellingskeuken en contractcatering

BB Verpleging en verzorging

$\begin{array}{llr}57 & 31 & 12 \\ 65 & 21 & 15 \\ 73 & 27 & 0 \\ 51 & 49 & 0 \\ 75 & 25 & 0 \\ 53 & 43 & 4 \\ 69 & 31 & 0 \\ 50 & 45 & 5 \\ 32 & 57 & 12 \\ 54 & 34 & 13 \\ 65 & 29 & 6 \\ 55 & 38 & 7\end{array}$

BOL niveau $3 / 4$

ZB Plantenteelt

ZB Veehouderij

ZB Bloemschikken

ZB Groene ruimte

KF Plantenteelt

KF Veehouderi

KF Levensmiddelentechnologie

KF Bloemschikken

KF Dierverzorging en veterinaire ondersteuning

KF Groene ruimte

KF Milieutoezicht

MKF Bouw

MKF Houtbewerking en woninginrichting

MKF Grond-, water- en wegenbouw

MKF Beschermings- en afwerkingstechnieken

MKF Reclame, presentatie en communicatie

MKF Fijnmechanische techniek

MKF Operationele techniek

MKF Werktuigbouwkunde

MKF Motorvoertuigen

MKF Energie- en informatietechniek

MKF Informatietechniek

MKF Scheepsbouwkundige (scheepsbouw)

MKF Grafische techniek, communicatie, audiovisueel

MKF Laboratoriumtechniek

MKF Procestechniek

MKF Scheepvaart

MKF Transport en logistiek

MKF Automatisering

MKF Bedrijfsadministratief

MKF Commercieel

MKF Economisch-juridisch

MKF Secretariee

MKF Detailhandel/ambulante handel

MKF Horeca, instellingskeuken en contractcatering

MKF Toerisme, recreatie en reizen

MKF Assistenten gezondheidszorg

\begin{tabular}{|c|c|}
\hline 63 & 36 \\
\hline 73 & 24 \\
\hline 68 & 29 \\
\hline 58 & 42 \\
\hline 70 & 28 \\
\hline 76 & 23 \\
\hline 81 & 19 \\
\hline 73 & 27 \\
\hline 91 & 9 \\
\hline 75 & 22 \\
\hline 61 & 39 \\
\hline 77 & 23 \\
\hline 90 & 10 \\
\hline 84 & 16 \\
\hline 76 & 24 \\
\hline 77 & 23 \\
\hline 67 & 33 \\
\hline 70 & 30 \\
\hline 74 & 25 \\
\hline 66 & 33 \\
\hline 72 & 28 \\
\hline 85 & 15 \\
\hline 56 & 40 \\
\hline 78 & 22 \\
\hline 70 & 30 \\
\hline 86 & 14 \\
\hline 78 & 20 \\
\hline 66 & 34 \\
\hline 59 & 41 \\
\hline 76 & 24 \\
\hline 65 & 34 \\
\hline 64 & 34 \\
\hline 69 & 31 \\
\hline 60 & 39 \\
\hline 61 & 39 \\
\hline 68 & 32 \\
\hline 78 & 21 \\
\hline
\end{tabular}

72 
Tabel B1.4 (vervolg)

Gevolgde opleiding opnieuw kiezen?

$\begin{array}{rrr}\text { Opleidingsrichting } & \begin{array}{r}\text { zelfde } \\ \text { opleiding }\end{array} & \begin{array}{r}\text { andere } \\ \text { opleiding }\end{array} \\ & \begin{array}{r}\text { geen } \\ \text { andere } \\ \text { opleiding }\end{array}\end{array}$

BOL niveau 3/4 (vervolg)

MKF Facilitaire dienstverlening

MKF Sport en bewegen

MKF Verpleging en verzorging

ZB Uiterlijke verzorging

MKF Sociaal-cultureel werker

MKF Sociaal-pedagogisch werk algemeen

MKF Sociaal-juridisch werk

$\begin{array}{lrl}42 & 50 & 8 \\ 88 & 9 & 3 \\ 62 & 37 & 1 \\ 60 & 36 & 4 \\ 64 & 35 & 1 \\ 73 & 26 & 1 \\ 73 & 27 & 1\end{array}$

BBL niveau $1 / 2$

BB Bouw

BB Beschermings- en afwerkingstechnieken

BB Constructie(bank)werken/(isolatie)plaatwerken/pijpenbew.

BB Machinebankwerken/verspanen

BB Energie- en informatietechniek

BB Wegvervoer

BB Secretarieel

BB Detailhandel/ambulante handel

BB Horeca, instellingskeuken en contractcatering

BB Facilitaire dienstverlening

BB Verpleging en verzorging

\section{BBL niveau 3/4}

MKF Bouw

ZB Grond-, water- en wegenbouw

ZB Contructie(bank)werken/(isolatie)plaatwerken/pijpenbew.

MKF Motorvoertuigen

Specialist Energie- en informatietechniek

Specialist Installatie-, service- en onderhoudstechniek

MKF Procestechniek

MKF Automatisering

MKF Detailhandel/ambulante handel

MKF Horeca, instellingskeuken en contractcatering

MKF Verpleging en verzorging

ZB Uiterlijke verzorging

MKF Sociaal-pedagogisch werk

$\begin{array}{lrr}87 & 11 & 2 \\ 70 & 20 & 10 \\ 56 & 39 & 5 \\ 95 & 5 & 0 \\ 86 & 14 & 0 \\ 90 & 3 & 7 \\ 85 & 10 & 5 \\ 60 & 32 & 8 \\ 52 & 44 & 4 \\ 66 & 32 & 2 \\ 64 & 35 & 1 \\ 71 & 29 & 0 \\ 71 & 23 & 7\end{array}$


Tabel B2. 1

Doorstroom van schoolverlaters naar vervolgonderwijs

\begin{tabular}{|c|c|c|c|c|c|c|c|c|c|}
\hline \multirow[t]{2}{*}{ Opleidingsrichting } & $\begin{array}{r}\text { verder } \\
\text { leren }\end{array}$ & MAVO & HAVO & VBO & $\begin{array}{r}\mathrm{BOL} \\
\text { niv. } 1 / 2\end{array}$ & $\begin{array}{r}\text { BOL } \\
\text { niv. } 3 / 4\end{array}$ & $\begin{array}{r}\mathrm{BBL} \\
\text { niv. } 1 / 2\end{array}$ & $\begin{array}{r}\text { BBL } \\
\text { niv. } 3 / 4\end{array}$ & $\mathrm{HBO}$ \\
\hline & $\%$ & $\%$ & $\%$ & $\%$ & $\%$ & $\%$ & $\%$ & $\%$ & $\%$ \\
\hline \multicolumn{10}{|l|}{ VBO } \\
\hline IVBO Landbouw en natuurlijke omgeving & 81 & 1 & 0 & 0 & 46 & 29 & 17 & 7 & 0 \\
\hline IVBO Verzorging & 96 & 0 & 0 & 0 & 63 & 12 & 17 & 8 & 0 \\
\hline Landbouw en natuurlijke omgeving & 92 & 1 & 0 & 0 & 16 & 69 & 9 & 4 & 0 \\
\hline Bouwtechniek & 87 & 0 & 0 & 0 & 13 & 49 & 24 & 14 & 0 \\
\hline Mechanische techniek & 88 & 3 & 0 & 0 & 6 & 46 & 26 & 20 & 0 \\
\hline Elektrotechniek & 89 & 0 & 0 & 0 & 8 & 71 & 15 & 6 & 0 \\
\hline Motorvoertuigentechniek & 92 & 0 & 0 & 0 & 0 & 29 & 65 & 6 & 0 \\
\hline Consumptieve techniek & 87 & 5 & 0 & 0 & 20 & 30 & 35 & 10 & 0 \\
\hline Administratie & 92 & 1 & 0 & 0 & 28 & 66 & 4 & 1 & 0 \\
\hline Verkoop & 87 & 0 & 0 & 0 & 24 & 58 & 14 & 4 & 0 \\
\hline Handel & 92 & 0 & 0 & 0 & 12 & 71 & 6 & 12 & 0 \\
\hline Verzorging & 96 & 1 & 0 & 0 & 20 & 60 & 8 & 12 & 0 \\
\hline Uiterlijke verzorging & 90 & 0 & 0 & 0 & 25 & 40 & 15 & 20 & 0 \\
\hline \multicolumn{10}{|l|}{ BOL niveau $1 / 2$} \\
\hline BB Bedrijfsadministratie & 45 & 0 & 0 & 0 & 3 & 72 & 3 & 21 & 0 \\
\hline BB Secretarieel & 40 & 0 & 0 & 0 & 3 & 86 & 0 & 3 & 8 \\
\hline BB Detailhandel/ambulante handel & 43 & 0 & 0 & 0 & 5 & 59 & 21 & 15 & 0 \\
\hline BB Verpleging en verzorging & 71 & 0 & 0 & 0 & 5 & 55 & 21 & 19 & 0 \\
\hline \multicolumn{10}{|l|}{ BOL niveau $3 / 4$} \\
\hline ZB Bloemschikken & 27 & 0 & 2 & 8 & 20 & 0 & 4 & 63 & 4 \\
\hline KF Plantenteelt & 59 & 0 & 0 & 0 & 2 & 15 & 0 & 0 & 83 \\
\hline KF Veehouderij & 36 & 0 & 0 & 0 & 0 & 6 & 1 & 4 & 89 \\
\hline KF Bloemschikken & 32 & 0 & 0 & 0 & 0 & 27 & 0 & 24 & 49 \\
\hline KF Groene ruimte & 52 & 0 & 0 & 0 & 3 & 18 & 0 & 0 & 78 \\
\hline
\end{tabular}


Tabel B2.1 (vervolg)

Doorstroom van schoolverlaters naar vervolgonderwijs

\begin{tabular}{|c|c|c|c|c|c|c|c|c|c|}
\hline \multirow[t]{2}{*}{ Opleidingsrichting } & $\begin{array}{r}\text { verder } \\
\text { leren }\end{array}$ & MAVO & HAVO & VBO & $\begin{array}{r}\mathrm{BOL} \\
\text { niv. } 1 / 2\end{array}$ & $\begin{array}{r}\text { BOL } \\
\text { niv. } 3 / 4\end{array}$ & $\begin{array}{r}\mathrm{BBL} \\
\text { niv. } 1 / 2\end{array}$ & $\begin{array}{r}\text { BBL } \\
\text { niv. } 3 / 4\end{array}$ & $\mathrm{HBO}$ \\
\hline & $\%$ & $\%$ & $\%$ & $\%$ & $\%$ & $\%$ & $\%$ & $\%$ & $\%$ \\
\hline
\end{tabular}

BOL niveau $\mathbf{3 / 4}$ (vervolg)

KF Milieutoezicht

MKF Bouw

MKF Houtbewerking en woninginrichting

MKF Grond-, water- en wegenbouw

MKF Reclame, presentatie en communicatie

MKF Werktuigbouwkunde

MKF Motorvoertuigen

MKF Energie- en informatietechniek

MKF Information inormati

MKF Grafische techniek, communicatie, audiovisuee

MKF Laboratoriumtechniek

MKF Scheepvaart

MKF Bedrijfsadministratie

MKF Commercieel

MKF Economisch-juridisch

MKF Secretarieel

MKF Detailhandel/ambulante handel

MKF Horeca, instellingskeuken en contractcatering

MKF Toerisme, recreatie en reizen

MKF Assistenten gezondheidszorg

MKF Facilitaire dienstverlening

MKF Sport en bewegen

MKF Verpleging en verzorging

MKF Sociaal-cultureel werker

MKF Sociaal-pedagogisch werk algemeen

MKF Sociaal-juridisch werk

$\begin{array}{lll}54 & 0 & 0 \\ 58 & 0 & 0 \\ 29 & 0 & 0 \\ 44 & 0 & 0 \\ 42 & 0 & 0 \\ 52 & 0 & 2 \\ 46 & 0 & 0 \\ 45 & 0 & 0 \\ 55 & 0 & 0 \\ 32 & 0 & 2 \\ 51 & 0 & 0 \\ 35 & 0 & 0 \\ 67 & 0 & 0 \\ 51 & 0 & 0 \\ 66 & 0 & 0 \\ 34 & 0 & 0 \\ 57 & 0 & 0 \\ 38 & 0 & 0 \\ 37 & 0 & 0 \\ 27 & 0 & 1 \\ 47 & 0 & 0 \\ 57 & 0 & 0 \\ 56 & 0 & 0 \\ 51 & 0 & 0 \\ 52 & 0 & 0 \\ 64 & 0 & 0\end{array}$


Tabel B2. 1 (vervolg)

Doorstroom van schoolverlaters naar vervolgonderwijs

Opleidingsrichting

verder MAVO HAVO VBO

BOL

BOL BOL

iv. $3 / 4$

BBL

BBL

BL

$\begin{array}{lllllll}\% & \% & \% & \% & \% & \% & \%\end{array}$

$\% \quad \%$

BB Bouw

BB Horeca, instellingskeuken en contractcatering

BB Verpleging en verzorging

$\begin{array}{llllrrrrr}53 & 0 & 0 & 0 & 5 & 0 & 11 & 84 & 0 \\ 79 & 0 & 0 & 0 & 13 & 13 & 27 & 47 & 0 \\ 30 & 0 & 0 & 0 & 0 & 19 & 20 & 61 & 0\end{array}$


Tabel B2.2

Belangrijkste opleidingen van schoolverlaters die een voltijd vervolgopleiding zijn gaan volgen

IVBO Landbouw en natuurlijke omgeving

BOL BB Helpende (verpleging en verzorging)

IVBO Verzorging

BOL BB Helpende (verpleging en verzorging) $\quad 22$

BOL AB Administratief medewerker

BOL BB Gezondheidszorg $\quad 6$

BOL ZB Verzorgende 6

BBL AB Horeca-assistent $\quad 6$

BBL BB Kok 6

BBL ZB Detailhandel/ambulante handel $\quad 6$

VBO Landbouw en natuurlijke omgeving

BOL KF Veehouderij

VBO Bouwtechniek

BOL MKF Bouwkunde

VBO Mechanische techniek

BOL MKF Werktuigbouwkunde

VBO Elektrotechniek

BOL MKF Elektrotechnische installatietechniek 15

BOL MKF Informatietechniek 11

BBL BB Monteur sterkstroominstallaties $\quad 7$

BOL BB Energie- en informatietechniek

VBO Motorvoertuigentechniek

BOL MKF Motorvoertuigen

BBL BB Autotechnicus/bedrijfsautotechnicus 18

BBL BB Autoschadehersteller 9

BBL BB Motorvoertuigen 9

VBO Consumptieve techniek

BOL BB Kok

BOL ZB Brood- en banketbakken

VBO Administratie

BOL MKF Bedrijfsadministratief

VBO Verkoop

BOL ZB Mode en kleding (realisatie)

BOL MKF Detailhandel/ambulante handel

$B O L A B$ Detailhandel/ambulante handel

BOL BB Verkoopmedewerker 
Tabel B2.2 (vervolg)

Belangrijkste opleidingen van schoolverlaters die een voltijd vervolgopleiding zijn gaan volgen

VBO Handel

BOL ZB Detailhandel/ambulante handel $\quad 9$

BOL MKF Sociaal-pedagogisch werk 9

BOL ZB Schoonheidsspecialist

BOL MKF Vormgever reclame, presentatie en communicatie $\quad 7$

BOL BB Monteur elektrische bedrijfsinstallaties

BOL ZB Economie $\quad 5$

BOL ZB Bedrijfsadministratief $\quad 5$

BOL MKF Bedrijfsadministratief $\quad 5$

BOL MKF Detailhandel/ambulante handel $\quad 5$

BOL MKF Apothekersassistent $\quad 5$

BBL BB Uiterlijke verzorging $\quad 5$

BBL ZB Eerste verkoper

BBL ZB Leidster kindercentra $\quad 5$

VBO Verzorging

BOL MKF Sociaal-pedagogisch werk 16

BOL BB Helpende (verpleging en verzorging) 9

BOL ZB Verzorgende $\quad 9$

VBO Uiterlijke verzorging

BOL ZB All-round kapper

BOL MKF Sociaal-pedagogisch werker 12

BBL BB Kapper $\quad 12$

BBL ZB All-round kapper $\quad 12$

BOL BB Bedrijfsadministratie

BOL MKF Economie $\quad 23$

BOL MKF Bedrijfsadministratief 16

BBL ZB Boekhoudkundig medewerker 6

BOL BB Secretarieel

BOL MKF Secretarieel $\quad 19$

BOL ZB Secretaresse $\quad 10$

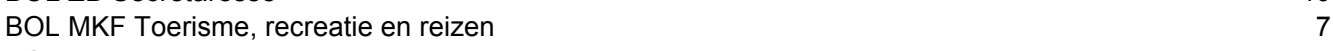

BOL MKF Reclame, presentatie en communicatie $\quad 5$

BOL BB Detailhandel/ambulante handel

BOL MKF Detailhandel/ambulante handel $\quad 15$

BBL BB Detailhandel/ambulante handel 9

BOL MKF Mode en kleding (realisatie) $\quad 6$

BOL MKF Economie $\quad 6$

BBL AB Detailhandel/ambulante handel 6

BOL BB Verpleging en verzorging

BBL BB Verpleging en verzorging 12

BOL ZB Verzorgende 11

BOL MKF Sociaal-pedagogisch werk 1

BBL ZB Verzorgende $\quad 8$

BOL MKF Verpleging en verzorging $\quad 6$

In-service Ziekenverzorgende $\quad 5$ 
Tabel B2.2 (vervolg)

Belangrijkste opleidingen van schoolverlaters die een voltijd vervolgopleiding zijn gaan volgen

\section{BOL ZB Bloemschikken}

BBL Specialist Bloemschikken $\quad 46$

BOL BB Bloemschikken $\quad 14$

$\begin{array}{ll}\text { VBO Economie } & 7\end{array}$

$\begin{array}{lr}\text { BBL ZB Bloemschikken } & 7 \\ \text { BBL Specialist } & 7\end{array}$

\section{BOL KF Plantenteelt}

HBO Agrarische bedrijfskunde $\quad 17$

HBO Land-, water- en milieubeheer 11

HBO Plantenteelt $\quad 10$

HBO Landbouw $\quad 6$

HBO Tuinbouw

BOL KF Veehouderij

HBO Veehouderij

HBO Agrarische bedrijfskunde

$\begin{array}{ll}\text { HBO Landbouw } & 7\end{array}$

\section{BOL KF Bloemschikken}

BBL Specialist Bloemschikken $\quad 18$

HBO Beeldende kunst en vormgeving - vrij

BOL KF Biologisch-dynamische land- en tuinbouw 11

BOL KF Groenbeheer 11

HBO Kunst en cultuur $\quad 11$

HBO Docent plantenteelt/bloemsierkunst (2e gr.) $\quad 8$

BOL KF Groene ruimte

HBO Tuin- en landschapsinrichting $\quad 27$

HBO Landbouw

$\begin{array}{ll}\text { HBO Bos- en natuurbeheer } & 7\end{array}$

BOL ZB Land, water en milieu $\quad 6$

BOL KF Milieutoezicht

HBO Milieukunde (agrarisch)

HBO Land-, water- en milieubeheer

HBO Milieutechnologie (technische) 18

HBO Landbouw 16

HBO Milieutechnologie (agrarische) 16

BOL MKF Bouw

HBO Bouwkunde $\quad 60$

HBO Bouwtechnische bedrijfskunde 13

BOL MKF Houtbewerking en woninginrichting

HBO Small business en retail management

HBO Commerciele economie $\quad 12$

$\begin{array}{lr}\text { HBO Bouwkunde } & 11\end{array}$

HBO Museologie $\quad 9$

BOL MKF Houtbewerking en woninginrichting

HBO Leraar VO geschiedenis (2e gr.)

HBO Bedrijfskaderopleiding (bouwkunde)

HBO Scheepsbouwkunde $\quad 5$

HBO Technische bedrijfskunde

HBO 3D-design $\quad 5$ 
Tabel B2.2 (vervolg)

Belangrijkste opleidingen van schoolverlaters die een voltijd vervolgopleiding zijn gaan volgen

BOL MKF Grond-, water- en wegenbouw

HBO Civiele techniek

BOL MKF Grond-, water- en wegenbouw

6

HBO Bouwkunde

BOL MKF Reclame, presentatie en communicatie

HBO Kunst en cultuur

HBO Publiciteits- c.q. grafische vormgeving

HBO Industrieel product ontwerpen

$\mathrm{HBO}$ Architectonische vormgeving

BOL MKF Werktuigbouwkunde

HBO Werktuigbouwkunde

HBO Technische bedrijfskunde

BOL MKF Motorvoertuigen

HBO Autotechniek

BOL MKF Bedrijfsmanagement motorvoertuigen

BBL BB Auto elektricien

BOL MKF Energie- en informatietechniek

HBO Elektrotechniek

HBO Hogere informatica

HBO Techniek

HBO Informatica

BOL MKF Informatietechniek

HBO Hogere informatica

HBO Informatica en informatiekunde

HBO Bedrijfskundige informatica

HBO Techniek

HBO Elektrotechniek

BOL MKF Grafische techniek, communicatie, audiovisueel

HBO Kunst en cultuur

HBO Communicatie

HBO Technische bedrijfskunde

HBO Commerciele economie

HBO Sociaal pedagogische hulpverlening

BOL MKF Laboratoriumtechniek

HBO Chemie

HBO Biologie en medisch laboratoriumonderzoek

$\begin{array}{ll}\text { HBO Technische natuurkunde } & 7\end{array}$

HBO Chemische technologie $\quad 7$

$\begin{array}{ll}\text { HBO Chemische laboratoriumopleiding } & 7\end{array}$

HBO Laboratoriumtechniek 6

BOL MKF Scheepvaart

HBO Maritiem officier 
Tabel B2.2 (vervolg)

Belangrijkste opleidingen van schoolverlaters die een voltijd vervolgopleiding zijn gaan volgen

BOL MKF Bedrijfsadministratief

HBO Bedrijfseconomie

21

HBO Management, economie en recht

HBO Accountancy

HBO Bedrijfskundige informatica

HBO Commerciele economie

BOL MKF Commercieel

HBO Commerciele economie

HBO Management, economie en recht

HBO Bedrijfseconomie

HBO Communicatie

BOL MKF Economisch-juridisch

HBO Bestuurskunde/overheidsmanagement 18

HBO Sociaal-juridische dienstverlening $\quad 16$

HBO Management, economie en recht

HBO Personeel en arbeid $\quad 12$

HBO Fiscale economie

BOL MKF Secretarieel

HBO Management

18

HBO Vrijetijdskunde 10

HBO Toerisme en recreatie (bedrijfsmanagement) 9

BOL MKF Detailhandel/ambulante handel

HBO Commerciele economie

HBO Small business en retail management

HBO Communicatie

HBO Bedrijfseconomie

BOL MKF Horeca, instellingskeuken en contractcatering

HBO Hoger hotelonderwijs

HBO Facilitaire dienstverlening

HBO Personeel en arbeid

HBO Kort Marketing management

BBL ZB Zelfstandig werkend kok

BOL MKF Toerisme, recreatie en reizen

HBO Toerisme en recreatie (bedrijfsmanagement)

HBO Management

HBO Vrijetijdskunde

BOL MKF Assistenten gezondheidszorg

HBO Opleiding mondhygienist

HBO Opleiding tot verpleegkundige

12

HBO Operatie-assistent chirurgie 
Tabel B2.2 (vervolg)

Belangrijkste opleidingen van schoolverlaters die een voltijd vervolgopleiding zijn gaan volgen

BOL MKF Facilitaire dienstverlening

HBO Facilitaire dienstverlening $\quad 18$

HBO Voeding en dietetiek $\quad 12$

BOL BB Beveiliging $\quad 6$

BOL MKF Apothekersassistent $\quad 6$

MBO Politie

BBL AB Detailhandel/ambulante handel $\quad 6$

BBL BB Kok

HBO Leraar basisonderwijs $\quad 6$

HBO Leraar VO consumptieve techniek I en II (2e gr.) 6

HBO Logistiek en economie $\quad 6$

HBO Toerisme en recreatie (bedrijfsmanagement)

HBO Vrijetijdskunde $\quad 6$

HBO Opleiding tot verpleegkundige $\quad 6$

HBO Personeelsmanagement $\quad 6$

BOL MKF Sport en bewegen

HBO Leraar VO lichamelijke oefening (1e gr.)

HBO Sport en bewegen $\quad 15$

HBO Fysiotherapie $\quad 10$

HBO Leraar basisonderwijs

BOL MKF Verpleging en verzorging

HBO Opleiding tot verpleegkundige

BOL MKF Verpleegkundige

BBL MKF Verpleegkundige $\quad 17$

BOL MKF Sociaal-cultureel werker

HBO Culturele en maatschappelijke vorming $\quad 34$

HBO Maatschappelijk werk en dienstverlening

HBO Leraar basisonderwijs 14

HBO Toerisme en recreatie (bedrijfsmanagement)

BOL MKF Sociaal-pedagogisch werk algemeen

HBO Sociaal pedagogische hulpverlening 30

HBO Leraar basisonderwijs $\quad 28$

HBO Maatschappelijk werk en dienstverlening $\quad 9$

HBO Pedagogiek $\quad 5$

BOL MKF Sociaal-juridisch werk

HBO Personeel en arbeid

HBO Maatschappelijk werk en dienstverlening $\quad 25$

HBO Sociaal-juridische dienstverlening 16

BBL BB Bouw

BBL ZB Voortgezette timmerkracht

BBL ZB Voortgezette metselaar

BBL BB Primaire timmerkracht $\quad 5$

BBL ZB Bouw 
Tabel B2.2 (vervolg)

Belangrijkste opleidingen van schoolverlaters die een voltijd vervolgopleiding zijn gaan volgen

BBL BB Horeca, instellingskeuken en contractcatering

BBL ZB Zelfstandig werkend kok

BBL BB Kok

BBL ZB Zelfstandig werkend gastheer/-vrouw

BOL BB KoK

BOL BB Gastheer/-vrouw

BOL ZB Zelfstandig werkend medewerker recreatie

BOL MKF

BOL MKF Multimedia vormgever

BBL BB Warehousemedewerker

BBL BB Gastheer/-vrouw

BBL KF Landbouw

BBL Specialist Instellingskok

BBL BB Verpleging en verzorging

BBL MKF Verpleegkundige

BBL BB Voedingsassistent

BOL MKF Verpleegkundige

Zie ook toelichting bladzijde 18 
Tabel B2.3

Oordeel van schoolverlaters over de aansluiting van de afgesloten opleiding met de voltijd vervolgopleiding

\begin{tabular}{lcccr} 
Opleidingsrichting & goed & $\begin{array}{r}\text { vol- } \\
\text { doende }\end{array}$ & matig & slecht \\
& & & & \\
& $\%$ & $\%$ & $\%$ & $\%$ \\
\hline VBO & & & & \\
IVBO Verzorging & 26 & 37 & 23 & 15 \\
Bouwtechniek & 30 & 42 & 21 & 7 \\
Mechanische techniek & 29 & 44 & 17 & 10 \\
Elektrotechniek & 35 & 32 & 21 & 11 \\
Motorvoertuigentechniek & 39 & 48 & 13 & 0 \\
Consumptieve techniek & 38 & 38 & 15 & 9 \\
Administratie & 30 & 43 & 18 & 9 \\
Verkoop & 29 & 36 & 29 & 6 \\
Handel & 18 & 25 & 37 & 19 \\
Verzorging & 32 & 37 & 21 & 10 \\
Uiterlijke verzorging & 27 & 50 & 19 & 4 \\
Mode en kleding & 38 & 30 & 22 & 9
\end{tabular}

BOL niveau $1 / 2$

BB Bedrijfsadministratie

BB Secretarieel

BB Detailhandel/ambulante handel

BB Verpleging en verzorging

$\begin{array}{rrrr}44 & 47 & 9 & 0 \\ 44 & 37 & 7 & 12 \\ 50 & 28 & 10 & 12 \\ 58 & 23 & 17 & 2\end{array}$

BOL niveau $3 / 4$

ZB Bloemschikken

KF Plantenteelt

KF Veehouderij

KF Bloemschikken

KF Groene ruimte

MKF Bouw

MKF Houtbewerking en woninginrichting

MKF Grond-, water- en wegenbouw

MKF Reclame, presentatie en communicatie

MKF Werktuigbouwkunde

MKF Motorvoertuigen

MKF Energie- en informatietechniek

MKF Informatietechniek

MKF Grafische techniek, communicatie, audiovisueel

MKF Laboratoriumtechniek

MKF Scheepvaart

MKF Bedrijfsadministratief

MKF Commercieel

MKF Economisch-juridisch

MKF Secretarieel

MKF Detailhandel/ambulante handel

MKF Horeca, instellingskeuken en contractcatering

MKF Toerisme, recreatie en reizen

MKF Assistenten gezondheidszorg

MKF Sport en bewegen

MKF Verpleging en verzorging

MKF Sociaal-cultureel werker

MKF Sociaal-pedagogisch werk algemeen

MKF Sociaal-juridisch werk

$\begin{array}{rrrr}31 & 33 & 21 & 16 \\ 33 & 35 & 18 & 13 \\ 31 & 45 & 15 & 9 \\ 25 & 39 & 22 & 14 \\ 26 & 46 & 19 & 9 \\ 33 & 47 & 11 & 9 \\ 33 & 28 & 24 & 15 \\ 37 & 47 & 11 & 5 \\ 27 & 43 & 27 & 2 \\ 46 & 40 & 9 & 4 \\ 45 & 36 & 19 & 0 \\ 36 & 41 & 16 & 7 \\ 42 & 44 & 10 & 4 \\ 52 & 24 & 16 & 9 \\ 34 & 39 & 24 & 2 \\ 25 & 36 & 30 & 9 \\ 44 & 36 & 17 & 3 \\ 26 & 39 & 21 & 14 \\ 18 & 53 & 22 & 6 \\ 30 & 51 & 10 & 9 \\ 23 & 41 & 25 & 11 \\ 37 & 24 & 32 & 7 \\ 40 & 37 & 16 & 6 \\ 33 & 39 & 21 & 7 \\ 46 & 33 & 19 & 2 \\ 36 & 38 & 22 & 5 \\ 48 & 35 & 4 & 13 \\ 37 & 41 & 17 & 6 \\ 32 & 41 & 16 & 11\end{array}$

Zie ook toelichting bladzijde 19 
Tabel B2.4

Doorstroom van schoolverlaters naar de beroepsbegeleidende leerweg

IVBO Landbouw en natuurlijke omgeving

LOBAS

Handel/L-OVD

OVDB

IVBO Verzorging

OVDB

ECABO

SVH

Handel/L-OVD

VBO Landbouw en natuurlijke omgeving

LOBAS

OVDB

VBO Bouwtechniek

SVB

SH\&M

VBO Mechanische techniek

SOM

Intechnium

INNOVAM

VTL

VBO Elektrotechniek

VEV/LOB-E

ECABO

VBO Motorvoertuigentechniek

INNOVAM

VOC-Car

VTL

VBO Consumptieve techniek

$\mathrm{SVH}$

SOB\&B

VBO Administratie

ECABO

VBO Verkoop

Handel/L-OVD

VOC/BETEX

OVDB

SVH 
Tabel B2.4 (vervolg)

Doorstroom van schoolverlaters naar de beroepsbegeleidende leerweg

$\begin{array}{lr}\text { VBO Handel } & 29 \\ \text { OVDB } & 23 \\ \text { Handel/L-OVD } & 13 \\ \text { KOC } & 11 \\ \text { ECABO } & 7 \\ \text { SVS } & 5 \\ \text { VEVILOB-E } & 5\end{array}$

VBO Verzorging

OVDB

Handel/L-OVD

$\mathrm{KOC}$

VBO Uiterlijke verzorging

KOC

OVDB

VBO Mode en kleding

Handel/L-OVD

OVDB

SVH

BOL BB Bedrijfsadministratie

ECABO

OVDB

BOL BB Secretarieel

ECABO

OVDB

Handel/L-OVD

SVH

BOL BB Detailhandel/ambulante handel

Handel/L-OVD

ECABO

VOC/BETEX

BOL BB Verpleging en verzorging

OVDB

Handel/L-OVD

In-service Ziekenverzorgende

BOL ZB Bloemschikken

LOBAS

BOL/BBL rest

BOL MKF Detailhandel/ambulante handel

ECABO

OVDB

INNOVAM 
Tabel B2.4 (vervolg)

Doorstroom van schoolverlaters naar de beroepsbegeleidende leerweg

BOL MKF Sociaal-pedagogisch werk algemeen

OVDB

70

ECABO

BBL BB Bouw

SVB

BBL BB Horeca, instellingskeuken en contractcatering

SVH

$\mathrm{VTL}$

GOC

BBL BB Verpleging en verzorging

OVDB

Zie ook toelichting bladzijde 22 
Tabel B3. 1

Werkloosheid en gemiddelde intredewerkloosheid van schoolverlaters die zich aanbieden op de arbeidsmarkt

\begin{tabular}{|c|c|c|c|c|c|c|c|c|}
\hline \multirow[t]{2}{*}{ Opleidingsrichting } & \multirow{2}{*}{$\begin{array}{r}\text { aanbieden } \\
\text { op arbeids- } \\
\text { markt } \\
\%\end{array}$} & \multirow{2}{*}{$\begin{array}{r}\text { werk- } \\
\text { loosheid } \\
\% \\
\%\end{array}$} & \multicolumn{5}{|c|}{ werkloos tijdens intredeperiode in klassen } & \multirow{2}{*}{$\begin{array}{r}\text { intrede- } \\
\text { werk- } \\
\text { loosheid } \\
\text { maanden }\end{array}$} \\
\hline & & & $\begin{array}{r}0 \text { mnd. } \\
\%\end{array}$ & $\begin{array}{r}1-3 \text { mnd. } \\
\%\end{array}$ & $\begin{array}{r}4-6 \text { mnd. } \\
\%\end{array}$ & $\begin{array}{r}7-12 \text { mnd. } \\
\%\end{array}$ & $\begin{array}{r}>=13 \text { mnd. } \\
\%\end{array}$ & \\
\hline \multicolumn{9}{|l|}{ VBO } \\
\hline IVBO Landbouw en natuurlijke omgeving & 47 & 17 & 71 & 19 & 4 & 3 & 3 & 1,3 \\
\hline Landbouw en natuurlijke omgeving & 33 & 10 & 86 & 12 & 1 & 1 & 0 & 0,4 \\
\hline Bouwtechniek & 55 & 0 & 80 & 20 & 0 & 0 & 0 & 0,4 \\
\hline Mechanische techniek & 61 & 3 & 89 & 11 & 0 & 0 & 0 & 0,2 \\
\hline Elektrotechniek & 46 & 7 & 73 & 15 & 6 & 6 & 0 & 1,2 \\
\hline Motorvoertuigentechniek & 72 & 0 & 88 & 12 & 0 & 0 & 0 & 0,2 \\
\hline Consumptieve techniek & 71 & 4 & 79 & 16 & 5 & 0 & 0 & 0,5 \\
\hline Administratie & 27 & 13 & 80 & 17 & 3 & 0 & 0 & 0,4 \\
\hline Verkoop & 47 & 0 & 92 & 8 & 0 & 0 & 0 & 0,2 \\
\hline Verzorging & 28 & 0 & 82 & 16 & 0 & 3 & 0 & 0,6 \\
\hline \multicolumn{9}{|l|}{ BOL niveau $1 / 2$} \\
\hline BB Bloemschikken & 84 & 6 & 81 & 4 & 8 & 8 & 0 & 1,2 \\
\hline BB Bedrijfsadministratie & 67 & 4 & 76 & 13 & 4 & 7 & 0 & 1,2 \\
\hline BB Beveiliging & 90 & 0 & 85 & 10 & 0 & 5 & 0 & 0,6 \\
\hline BB Secretarieel & 80 & 12 & 68 & 17 & 9 & 2 & 4 & 1,9 \\
\hline BB Detailhandel/ambulante handel & 81 & 5 & 79 & 10 & 3 & 8 & 0 & 1,0 \\
\hline BB Horeca, instellingskeuken en contractcatering & 67 & 0 & 89 & 11 & 0 & 0 & 0 & 0,2 \\
\hline BB Verpleging en verzorging & 67 & 4 & 87 & 10 & 2 & 2 & 0 & 0,4 \\
\hline
\end{tabular}


Tabel B3. 1 (vervolg)

Werkloosheid en gemiddelde intredewerkloosheid van schoolverlaters die zich aanbieden op de arbeidsmarkt

\begin{tabular}{|c|c|c|c|c|c|c|c|c|}
\hline \multirow[t]{2}{*}{ Opleidingsrichting } & \multirow{2}{*}{$\begin{array}{r}\text { aanbieden } \\
\text { op arbeids- } \\
\text { markt } \\
\% \\
\end{array}$} & \multirow{2}{*}{$\begin{array}{r}\text { werk- } \\
\text { loosheid } \\
\%\end{array}$} & \multicolumn{5}{|c|}{ werkloos tijdens intredeperiode in klassen } & \multirow{2}{*}{$\begin{array}{r}\text { intrede- } \\
\text { werk- } \\
\text { loosheid } \\
\text { maanden }\end{array}$} \\
\hline & & & $\begin{array}{r}0 \text { mnd. } \\
\%\end{array}$ & $\begin{array}{r}1-3 \text { mnd. } \\
\% \\
\end{array}$ & $\begin{array}{r}4-6 \text { mnd. } \\
\% \\
\end{array}$ & $\begin{array}{r}7-12 \text { mnd. } \\
\% \\
\end{array}$ & $\begin{array}{r}>=13 \text { mnd. } \\
\%\end{array}$ & \\
\hline \multicolumn{9}{|l|}{ BOL niveau 3/4 } \\
\hline ZB Plantenteelt & 80 & 3 & 100 & 0 & 0 & 0 & 0 & 0,0 \\
\hline ZB Veehouderij & 86 & 3 & 88 & 4 & 7 & 0 & 1 & 0,6 \\
\hline ZB Bloemschikken & 84 & 6 & 87 & 12 & 1 & 0 & 0 & 0,3 \\
\hline ZB Groene ruimte & 67 & 0 & 93 & 2 & 0 & 5 & 0 & 0,4 \\
\hline KF Plantenteelt & 53 & 2 & 90 & 10 & 0 & 0 & 0 & 0,2 \\
\hline KF Veehouderij & 54 & 2 & 90 & 9 & 1 & 0 & 0 & 0,2 \\
\hline KF Levensmiddelentechnologie & 52 & 0 & 100 & 0 & 0 & 0 & 0 & 0,0 \\
\hline KF Bloemschikken & 75 & 4 & 83 & 14 & 2 & 0 & 2 & 0,5 \\
\hline KF Groene ruimte & 49 & 0 & 83 & 14 & 0 & 3 & 0 & 0,6 \\
\hline MKF Bouw & 51 & 3 & 90 & 10 & 0 & 0 & 0 & 0,2 \\
\hline MKF Houtbewerking en woninginrichting & 73 & 0 & 75 & 19 & 6 & 0 & 0 & 0,5 \\
\hline MKF Grond-, water- en wegenbouw & 51 & 0 & 90 & 10 & 0 & 0 & 0 & 0,2 \\
\hline MKF Reclame, presentatie en communicatie & 64 & 3 & 70 & 24 & 3 & 0 & 3 & 0,8 \\
\hline MKF Werktuigbouwkunde & 58 & 0 & 94 & 6 & 0 & 0 & 0 & 0,1 \\
\hline MKF Motorvoertuigen & 75 & 0 & 92 & 8 & 0 & 0 & 0 & 0,2 \\
\hline MKF Energie- en informatietechniek & 63 & 1 & 92 & 7 & 0 & 0 & 1 & 0,2 \\
\hline MKF Informatietechniek & 51 & 0 & 100 & 0 & 0 & 0 & 0 & 0,0 \\
\hline MKF Grafische techniek, communicatie, audiovisueel & 73 & 1 & 85 & 11 & 3 & 0 & 1 & 0,4 \\
\hline MKF Laboratoriumtechniek & 57 & 7 & 79 & 11 & 8 & 2 & 0 & 0,7 \\
\hline MKF Scheepvaart & 72 & 2 & 81 & 14 & 3 & 3 & 0 & 0,6 \\
\hline MKF Transport en logistiek & 82 & 17 & 100 & 0 & 0 & 0 & 0 & 0,0 \\
\hline MKF Bedrijfsadministratief & 50 & 2 & 90 & 9 & 1 & 0 & 0 & 0,2 \\
\hline MKF Commercieel & 57 & 1 & 93 & 7 & 0 & 0 & 0 & 0,1 \\
\hline
\end{tabular}


Tabel B3. 1 (vervolg)

Werkloosheid en gemiddelde intredewerkloosheid van schoolverlaters die zich aanbieden op de arbeidsmarkt

\begin{tabular}{|c|c|c|c|c|c|c|c|c|}
\hline \multirow[t]{2}{*}{ Opleidingsrichting } & \multirow{2}{*}{$\begin{array}{r}\text { aanbieden } \\
\text { op arbeids- } \\
\text { markt } \\
\% \\
\%\end{array}$} & \multirow{2}{*}{$\begin{array}{r}\text { werk- } \\
\text { loosheid } \\
\% \\
\%\end{array}$} & \multicolumn{5}{|c|}{ werkloos tijdens intredeperiode in klassen } & \multirow{2}{*}{$\begin{array}{r}\text { intrede- } \\
\text { werk- } \\
\text { loosheid } \\
\text { maanden }\end{array}$} \\
\hline & & & $\begin{array}{r}0 \text { mnd. } \\
\%\end{array}$ & $\begin{array}{r}1-3 \text { mnd. } \\
\%\end{array}$ & $\begin{array}{r}4-6 \text { mnd. } \\
\% \\
\end{array}$ & $\begin{array}{r}7-12 \text { mnd. } \\
\% \\
\end{array}$ & $\begin{array}{r}>=13 \text { mnd. } \\
\%\end{array}$ & \\
\hline \multicolumn{9}{|l|}{ BOL niveau 3/4 (vervolg) } \\
\hline MKF Economisch-juridisch & 41 & 3 & 71 & 18 & 11 & 0 & 0 & 0,8 \\
\hline MKF Secretarieel & 76 & 2 & 92 & 7 & 1 & 1 & 0 & 0,2 \\
\hline MKF Detailhandel/ambulante handel & 58 & 3 & 90 & 9 & 0 & 0 & 0 & 0,2 \\
\hline MKF Horeca, instellingskeuken en contractcatering & 70 & 0 & 87 & 10 & 3 & 0 & 0 & 0,2 \\
\hline MKF Toerisme, recreatie en reizen & 67 & 1 & 87 & 11 & 2 & 0 & 0 & 0,3 \\
\hline MKF Assistenten gezondheidszorg & 82 & 0 & 91 & 8 & 0 & 1 & 0 & 0,3 \\
\hline MKF Facilitaire dienstverlening & 74 & 0 & 84 & 12 & 0 & 0 & 4 & 1,1 \\
\hline MKF Sport en bewegen & 53 & 1 & 78 & 18 & 1 & 3 & 0 & 0,6 \\
\hline MKF Verpleging en verzorging & 70 & 2 & 93 & 6 & 0 & 0 & 0 & 0,2 \\
\hline ZB Uiterlijke verzorging & 82 & 0 & 75 & 24 & 0 & 1 & 0 & 0,6 \\
\hline MKF Sociaal-cultureel werker & 54 & 4 & 86 & 7 & 5 & 2 & 0 & 0,5 \\
\hline MKF Sociaal-pedagogisch werk algemeen & 61 & 3 & 85 & 12 & 2 & 1 & 0 & 0,4 \\
\hline MKF Sociaal-juridisch werk & 55 & 4 & 91 & 4 & 3 & 0 & 2 & 0,5 \\
\hline \multicolumn{9}{|l|}{ BBL niveau $1 / 2$} \\
\hline BB Bouw & 98 & 0 & 97 & 1 & 1 & 0 & 0 & 0,1 \\
\hline BB Constructie(bank)werken/(isolatie)plaatwerken/pijpenbew. & 93 & 4 & 96 & 2 & 2 & 0 & 0 & 0,1 \\
\hline BB Machinebankwerken/verspanen & 100 & 0 & 100 & 0 & 0 & 0 & 0 & 0,0 \\
\hline BB Wegvervoer & 95 & 0 & 96 & 4 & 0 & 0 & 0 & 0,0 \\
\hline BB Detailhandel/ambulante handel & 91 & 3 & 85 & 12 & 4 & 0 & 0 & 0,5 \\
\hline BB Horeca, instellingskeuken en contractcatering & 93 & 0 & 91 & 9 & 0 & 0 & 0 & 0,1 \\
\hline BB Facilitaire dienstverlening & 100 & 0 & 96 & 0 & 0 & 4 & 0 & 0,5 \\
\hline BB Verpleging en verzorging & 91 & 4 & 72 & 14 & 14 & 0 & 0 & 1,0 \\
\hline
\end{tabular}


Tabel B3. 1 (vervolg)

Werkloosheid en gemiddelde intredewerkloosheid van schoolverlaters die zich aanbieden op de arbeidsmarkt

\begin{tabular}{|c|c|c|c|c|c|c|c|c|}
\hline \multirow[t]{2}{*}{ Opleidingsrichting } & \multirow{2}{*}{$\begin{array}{r}\text { aanbieden } \\
\text { op arbeids- } \\
\text { markt }\end{array}$} & $\begin{array}{r}\text { werk- } \\
\text { loosheid }\end{array}$ & \multicolumn{5}{|c|}{ werkloos tijdens intredeperiode in klassen } & \multirow{2}{*}{$\begin{array}{r}\text { intrede- } \\
\text { werk- } \\
\text { loosheid } \\
\text { maanden }\end{array}$} \\
\hline & & $\%$ & $\begin{array}{r}0 \text { mnd. } \\
\%\end{array}$ & $\begin{array}{r}1-3 \text { mnd. } \\
\%\end{array}$ & $\begin{array}{r}4-6 \text { mnd. } \\
\%\end{array}$ & $\begin{array}{r}7-12 \text { mnd. } \\
\% \\
\end{array}$ & $\begin{array}{r}>=13 \text { mnd. } \\
\%\end{array}$ & \\
\hline \multicolumn{9}{|l|}{ BBL niveau $3 / 4$} \\
\hline MKF Bouw & 96 & 0 & 100 & 0 & 0 & 0 & 0 & 0,0 \\
\hline ZB Grond-, water- en wegenbouw & 100 & 0 & 100 & 0 & 0 & 0 & 0 & 0,0 \\
\hline ZB Contructie(bank)werken/(isolatie)plaatwerken/pijpenbew. & 93 & 7 & 92 & 8 & 0 & 0 & 0 & 0,2 \\
\hline MKF Motorvoertuigen & 91 & 0 & 100 & 0 & 0 & 0 & 0 & 0,0 \\
\hline Specialist Energie- en informatietechniek & 90 & 0 & 92 & 8 & 0 & 0 & 0 & 0,1 \\
\hline Specialist Installatie-, service- en onderhoudstechniek & 100 & 0 & 100 & 0 & 0 & 0 & 0 & 0,0 \\
\hline MKF Procestechniek & 100 & 0 & 94 & 0 & 0 & 6 & 0 & 0,5 \\
\hline MKF Detailhandel/ambulante handel & 97 & 0 & 95 & 5 & 0 & 0 & 0 & 0,1 \\
\hline MKF Horeca, instellingskeuken en contractcatering & 96 & 0 & 91 & 6 & 0 & 3 & 0 & 0,3 \\
\hline MKF Sociaal-pedagogisch werk & 98 & 0 & 82 & 9 & 6 & 3 & 0 & 0,6 \\
\hline
\end{tabular}

Zie ook toelichting bladzijde 25 
Tabel B3.2

Aard van het dienstverband van werkende schoolverlaters

\begin{tabular}{|c|c|c|c|c|c|c|c|}
\hline Opleidingsrichting & $\begin{array}{r}\text { leer/werk- } \\
\text { overeen- } \\
\text { komst } \\
\%\end{array}$ & $\begin{array}{r}\text { uitzend- } \\
\text { bureau } \\
\%\end{array}$ & $\begin{array}{l}\text { loondienst } \\
\text { werkgever }\end{array}$ & $\begin{array}{r}\text { oproep- of } \\
\text { nul-uren } \\
\text { contract } \\
\%\end{array}$ & $\begin{array}{r}\text { werk- } \\
\text { ervarings- } \\
\text { project } \\
\%\end{array}$ & $\begin{array}{r}\text { bedrijf } \\
\text { ouders/ } \\
\text { partner } \\
\%\end{array}$ & $\begin{array}{l}\text { eigen bedrijf/ } \\
\text { free-lance }\end{array}$ \\
\hline
\end{tabular}

VBO

IVBO Landbouw en natuurlijke omgeving

Landbouw en natuurlijke omgeving

Bouwtechniek

Mechanische techniek

Elektrotechniek

Motorvoertuigentechniek

Consumptieve techniek

Administratie

Verkoop

Verzorging

44
63
63
78
52
78
46
21
32
67

$\begin{array}{rr}12 & 39 \\ 4 & 28 \\ 0 & 34 \\ 3 & 16 \\ 4 & 44 \\ 0 & 22 \\ 12 & 38 \\ 22 & 54 \\ 4 & 57 \\ 2 & 30\end{array}$

$\begin{array}{lllll}39 & 3 & 3 & 0 & 0 \\ 28 & 2 & 1 & 2 & 1 \\ 34 & 0 & 0 & 0 & 3 \\ 16 & 3 & 0 & 0 & 0 \\ 44 & 0 & 0 & 0 & 0 \\ 22 & 0 & 0 & 0 & 0 \\ 38 & 0 & 0 & 4 & 0 \\ 54 & 0 & 3 & 0 & 0 \\ 57 & 4 & 0 & 4 & 0 \\ 30 & 0 & 0 & 0 & 0\end{array}$

BOL niveau $1 / 2$

BB Bloemschikken

BB Houtbewerking en woninginrichting

BB Bedrijfsadministratie

BB Beveiliging

BB Secretarieel

BB Detailhandel/ambulante handel

BB Horeca, instellingskeuken en contractcatering

BB Verpleging en verzorging

20
0
0
5
2
10
20
43

17
6
13
0
26
6
5
7

56

94

BOL niveau $3 / 4$

ZB Plantenteelt

ZB Veehouderij

ZB Bloemschikken

$\begin{array}{lrl}5 & 9 & 77 \\ 1 & 12 & 69 \\ 7 & 6 & 83 \\ 0 & 0 & 93\end{array}$

77
69
83
93

ZB Groene ruimte

$\begin{array}{lll}0 & 3 & 5 \\ 1 & 9 & 4 \\ 0 & 0 & 4 \\ 0 & 2 & 5\end{array}$


Tabel B3.2 (vervolg)

Aard van het dienstverband van werkende schoolverlaters

\begin{tabular}{|c|c|c|c|c|c|c|c|}
\hline Opleidingsrichting & $\begin{array}{r}\text { leer/werk- } \\
\text { overeen- } \\
\text { komst }\end{array}$ & $\begin{array}{c}\text { uitzend- } \\
\text { bureau }\end{array}$ & $\begin{array}{l}\text { loondienst } \\
\text { werkgever }\end{array}$ & $\begin{array}{l}\text { oproep- of } \\
\text { nul-uren } \\
\text { contract }\end{array}$ & $\begin{array}{r}\text { werk- } \\
\text { ervarings- } \\
\text { project }\end{array}$ & $\begin{array}{l}\text { bedrijf } \\
\text { ouders/ } \\
\text { partner }\end{array}$ & $\begin{array}{l}\text { eigen bedrijf/ } \\
\text { free-lance }\end{array}$ \\
\hline & $\%$ & $\%$ & $\%$ & $\%$ & $\%$ & $\%$ & $\%$ \\
\hline
\end{tabular}

BOL niveau 3/4 (vervolg)

KF Plantenteelt

KF Veehouderij

KF Levensmiddelentechnologie

KF Bloemschikken

KF Groene ruimte

MKF Bouw

MKF Houtbewerking en woninginrichting

MKF Grond-, water- en wegenbouw

MKF Reclame, presentatie en communicatie

MKF Werktuigbouwkunde

MKF Motorvoertuigen

MKF Energie- en informatietechniek

MKF Informatietechniek

MKF Grafische techniek, communicatie, audiovisuee

MKF Laboratoriumtechniek

MKF Scheepvaart

MKF Transport en logistiek

MKF Bedrijfsadministratief

MKF Commercieel

MKF Economisch-juridisch

MKF Secretarieel

MKF Detailhandel/ambulante hande

MKF Horeca, instellingskeuken en contractcatering

MKF Toerisme, recreatie en reizen

MKF Assistenten gezondheidszorg

$\begin{array}{rrr}0 & 10 & 76 \\ 2 & 13 & 64 \\ 0 & 0 & 96 \\ 5 & 5 & 84 \\ 6 & 10 & 77 \\ 0 & 7 & 91 \\ 2 & 5 & 89 \\ 0 & 0 & 95 \\ 0 & 3 & 92 \\ 1 & 8 & 89 \\ 2 & 7 & 84 \\ 2 & 6 & 88 \\ 0 & 0 & 100 \\ 0 & 3 & 93 \\ 0 & 27 & 68 \\ 3 & 2 & 87 \\ 0 & 0 & 98 \\ 2 & 8 & 87 \\ 2 & 6 & 90 \\ 0 & 7 & 81 \\ 1 & 13 & 86 \\ 1 & 5 & 92 \\ 4 & 9 & 81 \\ 1 & 7 & 91 \\ 3 & 2 & 95\end{array}$

$\begin{array}{ll}76 & \\ 64 & 0 \\ 96 & 0 \\ 84 & 0 \\ 77 & 0 \\ 91 & 0 \\ 89 & 0 \\ 95 & 0 \\ 92 & 0 \\ 89 & 0 \\ 84 & 0 \\ 88 & 0 \\ 00 & 0 \\ 93 & 0 \\ 68 & 0 \\ 87 & 5 \\ 98 & 0 \\ 87 & 0 \\ 90 & 1 \\ 81 & 1 \\ 86 & 0 \\ 92 & 0 \\ 81 & 1 \\ 91 & 1 \\ 95 & 0 \\ & 1\end{array}$

0
0
0
0
0
0
0
0
0
0
0
1
0
0
0
0
0
0
0
4
0
0
0
0
0


Tabel B3.2 (vervolg)

Aard van het dienstverband van werkende schoolverlaters

\begin{tabular}{|c|c|c|c|c|c|c|c|}
\hline Opleidingsrichting & $\begin{array}{r}\text { leer/werk- } \\
\text { overeen- } \\
\text { komst } \\
\%\end{array}$ & $\begin{array}{l}\text { uitzend- } \\
\text { bureau }\end{array}$ & $\begin{array}{l}\text { loondienst } \\
\text { werkgever }\end{array}$ & $\begin{array}{r}\text { oproep- of } \\
\text { nul-uren } \\
\text { contract } \\
\%\end{array}$ & $\begin{array}{r}\text { werk- } \\
\text { ervarings- } \\
\text { project } \\
\%\end{array}$ & $\begin{array}{r}\text { bedrijf } \\
\text { ouders/ } \\
\text { partner } \\
\%\end{array}$ & $\begin{array}{l}\text { eigen bedrijf/ } \\
\text { free-lance }\end{array}$ \\
\hline
\end{tabular}

BOL niveau $\mathbf{3 / 4}$ (vervolg)

MKF Facilitaire dienstverlening

MKF Sport en bewegen

MKF Verpleging en verzorging

ZB Uiterlijke verzorging

MKF Sociaal-cultureel werker

MKF Sociaal-pedagogisch werk algemeen

MKF Sociaal-juridisch werk

8
0
20
3
0
4
6

$\begin{array}{rl}8 & 71 \\ 5 & 86 \\ 1 & 71 \\ 0 & 87 \\ 2 & 67 \\ 4 & 81 \\ 15 & 77\end{array}$

\section{BBL niveau 1/2}

BB Bouw

BB Constructie(bank)werken/(isolatie)plaatwerken/pijpenbew.

BB Machinebankwerken/verspanen

BB Wegvervoer

BB Detailhandel/ambulante handel

BB Horeca, instellingskeuken en contractcatering

BB Facilitaire dienstverlening

BB Verpleging en verzorging

\section{BBL niveau 3/4}

MKF Bouw

ZB Grond-, water- en wegenbouw

ZB Contructie(bank)werken/(isolatie)plaatwerken/pijpenbew. MKF Motorvoertuigen

Specialist Energie- en informatietechniek

Specialist Installatie-, service- en onderhoudstechniek

MKF Procestechniek

F Procestechniek

71
86
71
87
67
81
77


63
5
88
91
88
50
00
78

98
92
00
97
87
93
100

$\begin{array}{rl}8 & 4 \\ 1 & 0 \\ 7 & 0 \\ 6 & 0 \\ 20 & 0 \\ 10 & 0 \\ 2 & 0\end{array}$

$\begin{array}{ll}0 & 0 \\ 0 & 8 \\ 0 & 1 \\ 0 & 4 \\ 2 & 8 \\ 0 & 1 \\ 0 & 0\end{array}$


Tabel B3. 2 (vervolg)

Aard van het dienstverband van werkende schoolverlaters

\begin{tabular}{|c|c|c|c|c|c|c|c|}
\hline Opleidingsrichting & $\begin{array}{r}\text { leer/werk- } \\
\text { overeen- } \\
\text { komst } \\
\%\end{array}$ & $\begin{array}{r}\text { uitzend- } \\
\text { bureau } \\
\%\end{array}$ & $\begin{array}{r}\text { loondienst } \\
\text { werkgever } \\
\%\end{array}$ & $\begin{array}{r}\text { oproep- of } \\
\text { nul-uren } \\
\text { contract } \\
\%\end{array}$ & $\begin{array}{r}\text { werk- } \\
\text { ervarings- } \\
\text { project } \\
\%\end{array}$ & $\begin{array}{r}\text { bedrijf } \\
\text { ouders/ } \\
\text { partner } \\
\%\end{array}$ & $\begin{array}{l}\text { eigen bedrijf/ } \\
\text { free-lance }\end{array}$ \\
\hline \multicolumn{8}{|l|}{ BBL niveau 3/4 (vervolg) } \\
\hline MKF Automatisering & 0 & 0 & 100 & 0 & 0 & 0 & 0 \\
\hline MKF Detailhandel/ambulante handel & 7 & 5 & 88 & 0 & 0 & 0 & 0 \\
\hline MKF Horeca, instellingskeuken en contractcatering & 5 & 0 & 89 & 0 & 0 & 3 & 2 \\
\hline MKF Verpleging en verzorging & 3 & 4 & 93 & 0 & 0 & 0 & 0 \\
\hline ZB Uiterlijke verzorging & 0 & 0 & 94 & 0 & 0 & 6 & 0 \\
\hline MKF Sociaal-pedagogisch werk & 5 & 5 & 80 & 10 & 0 & 0 & 0 \\
\hline
\end{tabular}


Tabel B3.3

Percentage werkende schoolverlaters met een flexibele aanstelling

VBO

IVBO Landbouw en natuurlijke omgeving 28

Landbouw en natuurlijke omgeving 18

Mechanische techniek $\quad 10$

Elektrotechniek 14

Consumptieve techniek $\quad 16$

Administratie $\quad 35$

Verkoop 13

Verzorging 3

BOL niveau $1 / 2$

BB Bloemschikken

BB Bedrijfsadministratie $\quad 24$

BB Secretarieel $\quad 41$

BB Detailhandel/ambulante handel $\quad 11$

BB Horeca, instellingskeuken en contractcatering $\quad 17$

BB Verpleging en verzorging $\quad 22$

BOL niveau $3 / 4$

ZB Plantenteelt

ZB Veehouderij

ZB Groene ruimte

KF Plantenteelt $\quad 21$

KF Veehouderij 2

KF Bloemschikken $\quad 11$

KF Groene ruimte 14

MKF Bouw $\quad 12$

MKF Houtbewerking en woninginrichting $\quad 17$

MKF Grond-, water- en wegenbouw

MKF Reclame, presentatie en communicatie 12

MKF Werktuigbouwkunde 12

MKF Motorvoertuigen $\quad 14$

MKF Energie- en informatietechniek 10

MKF Grafische techniek, communicatie, audiovisueel $\quad 8$

MKF Laboratoriumtechniek

MKF Scheepvaart $\quad 11$

MKF Transport en logistiek $\quad 4$

MKF Bedrijfsadministratief 16

MKF Commercieel $\quad 15$

MKF Economisch-juridisch $\quad 13$

MKF Secretarieel 18

MKF Detailhandel/ambulante handel $\quad 14$

MKF Horeca, instellingskeuken en contractcatering $\quad 22$

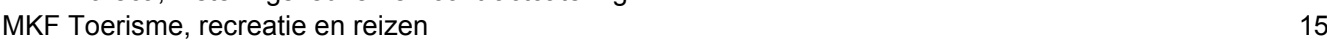

MKF Assistenten gezondheidszorg

MKF Facilitaire dienstverlening 33

MKF Sport en bewegen $\quad 16$

MKF Verpleging en verzorging 13

ZB Uiterlijke verzorging $\quad 19$

MKF Sociaal-cultureel werker 36

MKF Sociaal-pedagogisch werk algemeen $\quad 21$

MKF Sociaal-juridisch werk $\quad 25$ 
Tabel B3.3 (vervolg)

Percentage werkende schoolverlaters met een flexibele aanstelling

\section{BBL niveau $1 / 2$}

BB Constructie(bank)werken/(isolatie)plaatwerken/pijpenbew. 6

BB Machinebankwerken/verspanen

BB Wegvervoer 10

BB Horeca, instellingskeuken en contractcatering 13

BB Verpleging en verzorging $\quad 21$

BBL niveau $3 / 4$

ZB Grond-, water- en wegenbouw $\quad 5$

MKF Motorvoertuigen

Specialist Installatie-, service- en onderhoudstechniek $\quad 4$

MKF Procestechniek

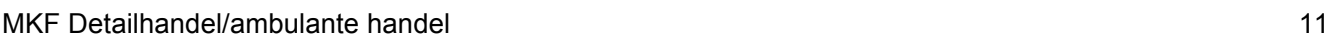

MKF Horeca, instellingskeuken en contractcatering 11

MKF Verpleging en verzorging 4

MKF Sociaal-pedagogisch werk $\quad 18$

Zie toelichting bladzijde 29 
Tabel B3. 4

Wijze van verkrijgen van een baan

\begin{tabular}{|c|c|c|c|c|c|c|c|c|c|c|c|}
\hline Opleidingsrichting & $\begin{array}{r}\text { arbeids- } \\
\text { bureau }\end{array}$ & $\begin{array}{c}\text { uitzend- } \\
\text { bureau }\end{array}$ & $\begin{array}{r}\text { adver- } \\
\text { tentie }\end{array}$ & $\begin{array}{l}\text { open } \\
\text { solli- } \\
\text { citatie }\end{array}$ & stage & $\begin{array}{r}\text { docent/ } \\
\text { ver.van } \\
\text { afgestud./ } \\
\text { alumni- } \\
\text { bureau } \\
\text { ed. }\end{array}$ & $\begin{array}{r}\text { bedrijven } \\
\text { infor- } \\
\text { matie- } \\
\text { dagen }\end{array}$ & $\begin{array}{r}\text { eerder } \\
\text { werk/ } \\
\text { interne } \\
\text { vacature }\end{array}$ & $\begin{array}{r}\text { familie/ } \\
\text { vrienden/ } \\
\text { kennis- } \\
\text { sen }\end{array}$ & $\begin{array}{r}\text { zelf } \\
\text { bedrijf } \\
\text { be- } \\
\text { gonnen }\end{array}$ & anders \\
\hline & $\%$ & $\%$ & $\%$ & $\%$ & $\%$ & $\%$ & $\%$ & $\%$ & $\%$ & $\%$ & $\%$ \\
\hline \multicolumn{12}{|l|}{ VBo } \\
\hline IVBO Landbouw en natuurlijke omgeving & 5 & 14 & 16 & 21 & 5 & 10 & 0 & 5 & 13 & 0 & 11 \\
\hline Landbouw en natuurlijke omgeving & 3 & 4 & 11 & 21 & 15 & 12 & 2 & 4 & 17 & 0 & 12 \\
\hline \multicolumn{12}{|l|}{ BOL niveau $1 / 2$} \\
\hline BB Bloemschikken & 10 & 10 & 22 & 13 & 32 & 0 & 0 & 0 & 7 & 0 & \\
\hline BB Houtbewerking en woninginrichting & 6 & 13 & 21 & 6 & 47 & 0 & 0 & 0 & 6 & 0 & \\
\hline BB Bedrijfsadministratie & 11 & 29 & 11 & 9 & 18 & 0 & 0 & 2 & 18 & 0 & \\
\hline BB Beveiliging & 5 & 6 & 0 & 27 & 10 & 16 & 5 & 0 & 26 & 0 & \\
\hline BB Secretarieel & 12 & 30 & 17 & 14 & 4 & 0 & 0 & 2 & 11 & 0 & \\
\hline BB Detailhandel/ambulante handel & 9 & 8 & 11 & 9 & 25 & 2 & 0 & 4 & 24 & 0 & \\
\hline BB Horeca, instellingskeuken en contractcatering & 5 & 0 & 20 & 30 & 15 & 0 & 0 & 5 & 25 & 0 & \\
\hline BB Verpleging en verzorging & 5 & 7 & 13 & 30 & 8 & 16 & 5 & 3 & 7 & 0 & \\
\hline \multicolumn{12}{|l|}{ BOL niveau 3/4 } \\
\hline ZB Plantenteelt & 1 & 7 & 1 & 12 & 32 & 5 & 0 & 5 & 10 & 8 & 17 \\
\hline ZB Veehouderij & 7 & 9 & 13 & 5 & 10 & 2 & 4 & 1 & 22 & 3 & 23 \\
\hline ZB Bloemschikken & 4 & 13 & 22 & 17 & 28 & 0 & 0 & 2 & 4 & 2 & 8 \\
\hline ZB Groene ruimte & 0 & 0 & 4 & 16 & 50 & 0 & 0 & 0 & 9 & 5 & 16 \\
\hline KF Plantenteelt & 0 & 20 & 10 & 6 & 21 & 0 & 2 & 4 & 8 & 11 & 17 \\
\hline KF Veehouderij & 4 & 9 & 12 & 11 & 10 & 1 & 1 & 5 & 17 & 20 & 11 \\
\hline KF Levensmiddelentechnologie & 0 & 20 & 38 & 11 & 12 & 0 & 0 & 0 & 0 & 4 & 15 \\
\hline KF Bloemschikken & 3 & 7 & 22 & 5 & 31 & 0 & 0 & 5 & 10 & 5 & 11 \\
\hline
\end{tabular}


Tabel B3.4 (vervolg)

Wijze van verkrijgen van een baan

\begin{tabular}{|c|c|c|c|c|c|c|c|c|c|c|c|}
\hline \multirow[t]{2}{*}{ Opleidingsrichting } & $\begin{array}{c}\text { arbeids- } \\
\text { bureau }\end{array}$ & $\begin{array}{l}\text { uitzend- } \\
\text { bureau }\end{array}$ & $\begin{array}{c}\text { adver- } \\
\text { tentie }\end{array}$ & $\begin{array}{r}\text { open } \\
\text { solli- } \\
\text { citatie }\end{array}$ & stage & $\begin{array}{r}\text { docent/ } \\
\text { ver.van } \\
\text { afgestud./ } \\
\text { alumni- } \\
\text { bureau } \\
\text { ed. }\end{array}$ & $\begin{array}{r}\text { bedrijven } \\
\text { infor- } \\
\text { matie- } \\
\text { dagen }\end{array}$ & $\begin{array}{r}\text { eerder } \\
\text { werk/ } \\
\text { interne } \\
\text { vacature }\end{array}$ & $\begin{array}{r}\text { familie/ } \\
\text { vrienden/ } \\
\text { kennis- } \\
\text { sen }\end{array}$ & $\begin{array}{r}\text { zelf } \\
\text { bedrijf } \\
\text { be- } \\
\text { gonnen }\end{array}$ & anders \\
\hline & $\%$ & $\%$ & $\%$ & $\%$ & $\%$ & $\%$ & $\%$ & $\%$ & $\%$ & $\%$ & $\%$ \\
\hline
\end{tabular}

BOL niveau 3/4 (vervolg)

KF Groene ruimte

MKF Bouw

MKF Houtbewerking en woninginrichting

MKF Grond-, water- en wegenbouw

MKF Reclame, presentatie en communicatie

MKF Werktuigbouwkunde

MKF Motorvoertuigen

MKF Energie- en informatietechniek

MKF Informatietechniek

MKF Grafische techniek, communicatie, audiovisuee

MKF Laboratoriumtechniek

MKF Scheepvaart

MKF Transport en logistiek

MKF Bedrijfsadministratief

MKF Commercieel

MKF Economisch-juridisch

MKF Secretarieel

MKF Detailhandel/ambulante hande

MKF Horeca, instellingskeuken en contractcatering

MKF Toerisme, recreatie en reizen

MKF Assistenten gezondheidszorg

$\begin{array}{rrr}7 & 8 & \\ 8 & 16 & \\ 4 & 6 & 11 \\ 5 & 9 & 23 \\ 6 & 14 & 30 \\ 5 & 23 & 14 \\ 6 & 6 & 12 \\ 7 & 17 & 10 \\ 0 & 15 & 20 \\ 0 & 16 & 15 \\ 5 & 24 & 14 \\ 3 & 5 & \\ 0 & 20 & \\ 11 & 26 & 17 \\ 4 & 24 & 20 \\ 7 & 25 & 21 \\ 5 & 38 & 19 \\ 8 & 13 & 21 \\ 5 & 20 & 19 \\ 4 & 18 & 15 \\ 2 & 6 & 25\end{array}$

11
5
10
23
30
14
12
10
20
15
14
16
6
17
20
21
19
21
19
15
25

$\begin{array}{rr}14 & 35 \\ 8 & 27 \\ 12 & 34 \\ 9 & 36 \\ 14 & 6 \\ 11 & 22 \\ 18 & 38 \\ 11 & 27 \\ 0 & 15 \\ 9 & 24 \\ 13 & 21 \\ 17 & 34 \\ 0 & 11 \\ 8 & 18 \\ 12 & 17 \\ 4 & 7 \\ 7 & 15 \\ 12 & 13 \\ 16 & 17 \\ 16 & 32 \\ 16 & 28\end{array}$


Tabel B3.4 (vervolg)

Wijze van verkrijgen van een baan

\begin{tabular}{|c|c|c|c|c|c|c|c|c|c|c|c|}
\hline \multirow[t]{2}{*}{ Opleidingsrichting } & \multirow{2}{*}{$\begin{array}{r}\text { arbeids- } \\
\text { bureau } \\
\\
\% \\
\end{array}$} & \multirow{2}{*}{$\begin{array}{r}\text { uitzend- } \\
\text { bureau }\end{array}$} & \multirow{2}{*}{$\begin{array}{r}\text { adver- } \\
\text { tentie } \\
\\
\\
\% \\
\end{array}$} & \multirow{2}{*}{$\begin{array}{r}\text { open } \\
\text { solli- } \\
\text { citatie } \\
\\
\\
\% \\
\end{array}$} & \multirow{2}{*}{$\begin{array}{r}\text { stage } \\
\\
\\
\% \\
\end{array}$} & \multirow{2}{*}{$\begin{array}{r}\text { docent/ } \\
\text { ver.van } \\
\text { afgestud./ } \\
\text { alumni- } \\
\text { bureau } \\
\text { ed. } \\
\% \\
\end{array}$} & \multirow{2}{*}{$\begin{array}{r}\text { bedrijven } \\
\text { infor- } \\
\text { matie- } \\
\text { dagen } \\
\\
\% \\
\end{array}$} & \multirow{2}{*}{$\begin{array}{r}\text { eerder } \\
\text { werk/ } \\
\text { interne } \\
\text { vacature } \\
\\
\% \\
\end{array}$} & \multirow{2}{*}{$\begin{array}{r}\text { familie/ } \\
\text { vrienden/ } \\
\text { kennis- } \\
\text { sen } \\
\\
\% \\
\end{array}$} & \multirow{2}{*}{ 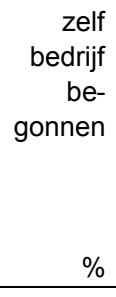 } & \multirow{2}{*}{$\begin{array}{r}\text { anders } \\
\\
\\
\% \\
\end{array}$} \\
\hline & & & & & & & & & & & \\
\hline \multicolumn{12}{|l|}{ BOL niveau 3/4 (vervolg) } \\
\hline MKF Facilitaire dienstverlening & 25 & 8 & 17 & 4 & 0 & 0 & 0 & 8 & 25 & 0 & 13 \\
\hline MKF Sport en bewegen & 3 & 5 & 17 & 15 & 15 & 12 & 1 & 1 & 16 & 0 & 15 \\
\hline MKF Verpleging en verzorging & 1 & 4 & 13 & 42 & 21 & 3 & 1 & 4 & 5 & 0 & \\
\hline ZB Uiterlijke verzorging & 1 & 4 & 20 & 18 & 24 & 4 & 0 & 1 & 10 & 4 & 13 \\
\hline MKF Sociaal-cultureel werker & 0 & 18 & 18 & 22 & 10 & 0 & 0 & 0 & 9 & 8 & 16 \\
\hline MKF Sociaal-pedagogisch werk algemeen & 5 & 7 & 17 & 27 & 18 & 1 & 0 & 5 & 11 & 1 & \\
\hline MKF Sociaal-juridisch werk & 2 & 29 & 23 & 10 & 17 & 2 & 0 & 0 & 12 & 0 & \\
\hline
\end{tabular}


Tabel B3.5

Belangrijkste bedrijfsgroepen waarin schoolverlaters werkzaam zijn

IVBO Landbouw en natuurlijke omgeving

Dienstverl. tbv landb. (excl. veterin.dienst.)

Niet-gespec. detailh. in winkel

Ov. gespec. detailh. in winkel

Restaurants/cafetaria's/snackbars e.d.

Ov. dienstverlening

18

6

VBO Landbouw en natuurlijke omgeving

Ov. gespec. detailh. in winkel

Niet-gespec. detailh. in winkel

Dienstverl. tbv landb. (excl. veterin.dienst.)

Ov. dienstverlening

VBO Bouwtechniek

Burgerl./utilit.;grond-/water-/wegenb. (excl. grondverz.)

Afwerken gebouwen

Vervoer over weg

VBO Mechanische techniek

Vervaard. metalen constructiew./ramen/deuren/kozijnen $\quad 13$

Vervaard. mach./appar.

Scheepsbouw/-reparatie

Handel in/repar. auto's (1)

Vervoer over weg

Bouwinstallatie

\section{VBO Elektrotechniek}

Bouwinstallatie

Burgerl./utilit.;grond-/water-/wegenb. (excl. grondverz.)

Vervaard. landbouwmach./-werkt.

Voorbereid. recycling afval (excl. metaalafval)

Afwerken gebouwen

Restaurants/cafetaria's/snackbars e.d.

Gezondheidszorg

VBO Motorvoertuigentechniek

Handel in/repar. auto's (1)

Smeden/persen/stampen/profielwals. metaal;poedermetallurgie

Handel in/repar. auto's (2)

Detailh. farmac./med. art./parfum/cosmet. in winkel

Ov. gespec. detailh. in winkel

Laad-/los-/overslagactiv./opslag

VBO Consumptieve techniek

Gespec. detailh. voed.-/genotmid. in winkel

Hotels/pensions/conferentie-oorden

Restaurants/cafetaria's/snackbars e.d.

Niet-gespec. detailh. in winkel 
Tabel B3.5 (vervolg)

Belangrijkste bedrijfsgroepen waarin schoolverlaters werkzaam zijn

\section{VBO Administratie}

Niet-gespec. detailh. in winkel 13

$\begin{array}{ll}\text { Overheidsdienst. } & 11\end{array}$

Geldscheppende financ. instell. $\quad 8$

\begin{tabular}{ll} 
Vervaard. ov. goederen n.e.g. & 7 \\
\hline
\end{tabular}

$\begin{array}{ll}\text { Bouwnijverheid } & 7\end{array}$

\begin{tabular}{ll} 
Grooth. ov. consumentenart. & 7 \\
\hline
\end{tabular}

Gespec. detailh. voed.-/genotmid. in winkel $\quad 7$

$\begin{array}{ll}\text { Ov. gespec. detailh. in winkel } & 7\end{array}$

Bouwinstallatie $\quad 6$

VBO Verkoop

Niet-gespec. detailh. in winkel $\quad 27$

Ov. gespec. detailh. in winkel $\quad 14$

Gespec. detailh. voed.-/genotmid. in winkel 10

Detailh. farmac./med. art./parfum/cosmet. in winkel $\quad 9$

Benzineservicestations $\quad 6$

Reiniging gebouwen/transportmid. e.d. $\quad 6$

Overheidsdienst.

VBO Verzorging

Welzijnszorg

Ov. gespec. detailh. in winkel 11

$\begin{array}{ll}\text { Gespec. detailh. voed.-/genotmid. in winkel } & 10\end{array}$

Ov. dienstverlening 10

Restaurants/cafetaria's/snackbars e.d. $\quad 9$

BOL BB Bloemschikken

Ov. gespec. detailh. in winkel

Slachterijen/vleesverwerking

Vervaard. farmac. prod.

Vervaard. geisoleerde kabel/draad

Niet-gespec. detailh. in winkel

BOL BB Houtbewerking en woninginrichting

Vervaard. meubels;vervaard. ov. goederen n.e.g. $\quad 32$

Ov. gespec. detailh. in winkel $\quad 23$

Vervaard. meubels $\quad 19$

Vervaard. textiel $\quad 6$

$\begin{array}{ll}\text { Scheepsbouw/-reparatie } & 6\end{array}$

Vervaard. muziekinstrum. $\quad 6$

Post-/koeriersdiensten $\quad 6$

BOL BB Bedrijfsadministratie

$\begin{array}{ll}\text { Rechtsk. dienstverl./account./belastingconsul./holdings e.d. } & 7\end{array}$

$\begin{array}{ll}\text { Openbaar bestuur } & 7\end{array}$

$\begin{array}{ll}\text { Welzijnszorg } & 7 \\ \end{array}$

BOL BB Beveiliging

Overheidsdienst.

Burgerl./utilit.;grond-/water-/wegenb. (excl. grondverz.)

Beveiliging/opsporing 11

Vervaard. voedingsmiddelen/dranken 6 
Tabel B3.5 (vervolg)

Belangrijkste bedrijfsgroepen waarin schoolverlaters werkzaam zijn

\section{BOL BB Secretarieel}

Burgerl./utilit.;grond-/water-/wegenb. (excl. grondverz.)

Ov. gespec. detailh. in winkel

Overheidsdienst.

Niet-gespec. detailh. in winkel

Geldscheppende financ. instell.

Openbaar bestuur

BOL BB Detailhandel/ambulante handel

Ov. gespec. detailh. in winkel

Niet-gespec. detailh. in winkel

Detailh. farmac./med. art./parfum/cosmet. in winkel

Ov. recreatie

BOL BB Horeca, instellingskeuken en contractcatering

Restaurants/cafetaria's/snackbars e.d.

Hotels/pensions/conferentie-oorden

Niet-gespec. detailh. in winkel

Gespec. detailh. voed.-/genotmid. in winkel

Gezondheidszorg

Ov. gespec. detailh. in winkel

Kampeerterreinen/ov. voorzien. recreat. verblijf n.e.g.

BOL BB Verpleging en verzorging

Welzijnszorg

Gezondheidszorg

Niet-gespec. detailh. in winkel

Gespec. detailh. voed.-/genotmid. in winkel

BOL ZB Plantenteelt

Akker-/tuinbouw

Ov. gespec. detailh. in winkel

Vervaard. zeep-,was-,reinig.-/onderhoudsmid.,parfum/cosmet.

Bouwrijp maken terreinen

BOL ZB Veehouderij

Fokken/houden dieren

Vervaard. zuivelprodukten

Ov. gespec. detailh. in winkel

BOL ZB Bloemschikken

Ov. gespec. detailh. in winkel

Grooth. landbouwprod./lev. dieren

BOL ZB Groene ruimte

Dienstverl. tbv landb. (excl. veterin.dienst.)

Ov. gespec. detailh. in winkel

\section{BOL KF Plantenteelt}

Akker-/tuinbouw

Grooth. landbouwprod./lev. dieren

Milieudienstverlening

Dienstverl. tbv landb. (excl. veterin.dienst.) 
Tabel B3.5 (vervolg)

Belangrijkste bedrijfsgroepen waarin schoolverlaters werkzaam zijn

BOL KF Veehouderij

Fokken/houden dieren

Architecten-/ingenieurs-/ov. techn.ontw.-/teken-/adviesbur.

Ov. gespec. detailh. in winkel

BOL KF Levensmiddelentechnologie

Natuurwet. speur-/ontwikkelingsw.

Slachterijen/vleesverwerking

Vervaard. meel

Niet-gespec. detailh. in winkel

Uitzendbur./uitleenbedr./arbeidsbemid./testen/werven/select.

Vervaard. ov. voedingsmid.

BOL KF Bloemschikken

Ov. gespec. detailh. in winkel

BOL KF Groene ruimte

Dienstverl. tbv landb. (excl. veterin.dienst.)

Ov. gespec. detailh. in winkel

Openbaar bestuur

Burgerl./utilit.;grond-/water-/wegenb. (excl. grondverz.)

BOL MKF Bouw

Architecten-/ingenieurs-/ov. techn.ontw.-/teken-/adviesbur.

Burgerl./utilit.;grond-/water-/wegenb. (excl. grondverz.)

Vervaard. timmerw.

Verhuur onroerend goed

Vervaard. meubels

Openbaar bestuur

BOL MKF Houtbewerking en woninginrichting

Vervaard. meubels

Ov. gespec. detailh. in winkel

Scheepsbouw/-reparatie

Grooth. intermediaire goederen (excl. agrar.)/afval/schroot

BOL MKF Grond-, water- en wegenbouw

Burgerl./utilit.;grond-/water-/wegenb. (excl. grondverz.)

Openbaar bestuur

Architecten-/ingenieurs-/ov. techn.ontw.-/teken-/adviesbur.

BOL MKF Reclame, presentatie en communicatie

Reklamebureaus e.d.

Ov. gespec. detailh. in winkel

Ov. zakelijke dienstverl. n.e.g

Vervaard. meubels

Niet-gespec. detailh. in winkel

Ov. dienstverl. op gebied automat. 
Tabel B3.5 (vervolg)

Belangrijkste bedrijfsgroepen waarin schoolverlaters werkzaam zijn

\section{BOL MKF Werktuigbouwkunde}

Bouwinstallatie

Vervaard. ov. mach./appar. voor alg. gebr.

Architecten-/ingenieurs-/ov. techn.ontw.-/teken-/adviesbur.

Vervaard. mach./appar.

Vervaard. prod. kunststof

Overheidsdienst.

BOL MKF Motorvoertuigen

Handel in/repar. auto's (1)

Handel in/repar. auto's (2)

BOL MKF Energie- en informatietechniek

Bouwinstallatie

Telecommunicatie

Overheidsdienst.

Ov. dienstverl. op gebied automat.

Computerservice-/informatietechnologiebur. e.d.

BOL MKF Informatietechniek

Systeemontwikkelings-/systeemanalyse-/programmeerdienst.

Adviesbur. op gebied automat./systeemh.

Uitzendbur./uitleenbedr./arbeidsbemid./testen/werven/select.

Ov. gespec. detailh. in winkel

Ov. dienstverl. op gebied automat.

Architecten-/ingenieurs-/ov. techn.ontw.-/teken-/adviesbur.

Openbaar bestuur

Voortgezet onderwijs

BOL MKF Grafische techniek, communicatie, audiovisueel Reklamebureaus e.d.

Drukkerijen/aanverwante activ.

BOL MKF Laboratoriumtechniek

Gezondheidszorg

Natuurwet. speur-/ontwikkelingsw.

Vervaard. basischemicalien

Vervaard. farmac. prod.

BOL MKF Scheepvaart

Zeevaart

Binnenvaart

Vervoer over water

Burgerl./utilit.;grond-/water-/wegenb. (excl. grondverz.)

BOL MKF Transport en logistiek

Expedit./cargad./bevracht.;weging/meting

Dienstverl. tbv vervoer

Rechtsk. dienstverl./account./belastingconsul./holdings e.d.

BOL MKF Bedrijfsadministratief

Rechtsk. dienstverl./account./belastingconsul./holdings e.d. 
Tabel B3.5 (vervolg)

Belangrijkste bedrijfsgroepen waarin schoolverlaters werkzaam zijn

\section{BOL MKF Commercieel}

Geldscheppende financ. instell.

Verzekeringsw./pensioenfonds. (excl. verpl. soc.verzek.)

Activ. verzekeringsw./pensioenfonds.

BOL MKF Economisch-juridisch

Rechtsk. dienstverl./account./belastingconsul./holdings e.d. 18

Verzekeringsw./pensioenfonds. (excl. verpl. soc.verzek.) 14

Openbaar bestuur

Groente-/fruitverwerking

Geldscheppende financ. instell.

BOL MKF Secretarieel

Rechtsk. dienstverl./account./belastingconsul./holdings e.d.

Gezondheidszorg

Openbaar bestuur

BOL MKF Detailhandel/ambulante handel

Ov. gespec. detailh. in winkel

Niet-gespec. detailh. in winkel

BOL MKF Horeca, instellingskeuken en contractcatering Hotels/pensions/conferentie-oorden

Restaurants/cafetaria's/snackbars e.d.

BOL MKF Toerisme, recreatie en reizen

Reisorgan./-bemid.;informatieverstrek. op gebied toerisme

Hotels/pensions/conferentie-oorden

Kampeerterreinen/ov. voorzien. recreat. verblijf n.e.g.

Geldscheppende financ. instell.

BOL MKF Assistenten gezondheidszorg

Gezondheidszorg

Detailh. farmac./med. art./parfum/cosmet. in winkel

BOL MKF Facilitaire dienstverlening

Restaurants/cafetaria's/snackbars e.d.

Niet-gespec. detailh. in winkel

Ov. gespec. detailh. in winkel

Overheidsdienst.

Welzijnszorg

BOL MKF Sport en bewegen

Sport

Overheidsdienst.

Welzijnszorg

Post-/koeriersdiensten

BOL MKF Verpleging en verzorging

Welzijnszorg 
Tabel B3.5 (vervolg)

Belangrijkste bedrijfsgroepen waarin schoolverlaters werkzaam zijn

BOL ZB Uiterlijke verzorging

Ov. dienstverlening

Detailh. farmac./med. art./parfum/cosmet. in winkel

Niet-gespec. detailh. in winkel

BOL MKF Sociaal-cultureel werker

Welzijnszorg

Vervaard. ov. voedingsmid.

Detailh. farmac./med. art./parfum/cosmet. in winkel

Ov. gespec. detailh. in winkel

BOL MKF Sociaal-pedagogisch werk algemeen Welzijnszorg

BOL MKF Sociaal-juridisch werk

Welzijnszorg

Gezondheidszorg

Verzekeringsw./pensioenfonds. (excl. verpl. soc.verzek.)

Uitzendbur./uitleenbedr./arbeidsbemid./testen/werven/select.

Verpl. soc. verzekeringen

Openbaar bestuur

Rechtsk. dienstverl./account./belastingconsul./holdings e.d.

Overheidsdienst.

\section{BBL BB Bouw}

Burgerl./utilit.;grond-/water-/wegenb. (excl. grondverz.)

BBL BB Constructie(bank)werken/(isolatie)plaatwerken/pijpenbew.

Bouwinstallatie

Vervaard. metalen constructiew./ramen/deuren/kozijnen

Vervaard. mach./appar.

BBL BB Machinebankwerken/verspanen

Vervaard. scharen/bestek/gereedsch./hang-/sluitw.

Vervaard. gereedschapswerkt.

Vervaard. prod. metaal (excl. mach./transportmid.)

Vervaard. metalen constructiew./ramen/deuren/kozijnen

Oppervlaktebehandeling/ov. metaalbewerking

Vervaard. rollend spoor-/tramwegmat.

Grooth. ov. consumentenart.

\section{BBL BB Wegvervoer}

Vervoer over weg

Laad-/los-/overslagactiv./opslag

BBL BB Detailhandel/ambulante handel

Niet-gespec. detailh. in winkel 
Tabel B3.5 (vervolg)

Belangrijkste bedrijfsgroepen waarin schoolverlaters werkzaam zijn

BBL BB Horeca, instellingskeuken en contractcatering

Restaurants/cafetaria's/snackbars e.d.

Hotels/pensions/conferentie-oorden

Welzijnszorg

Overig amusement/kunst

BBL BB Facilitaire dienstverlening

Welzijnszorg

Gezondheidszorg

Niet-gespec. detailh. in winkel

$B B L B B$ Verpleging en verzorging

Welzijnszorg

Gezondheidszorg

BBL MKF Bouw

Burgerl./utilit.;grond-/water-/wegenb. (excl. grondverz.)

Afwerken gebouwen

BBL ZB Grond-, water- en wegenbouw

Burgerl./utilit.;grond-/water-/wegenb. (excl. grondverz.)

Bouwrijp maken terreinen

Prod./distrib. elektriciteit/aardgas/stoom/warm water

BBL ZB Contructie(bank)werken/(isolatie)plaatwerken/pijpenbew.

Bouwinstallatie

Vervaard. metalen constructiew./ramen/deuren/kozijnen

Vervaard. prod. metaal (excl. mach./transportmid.)

Vervaard. tanks/reservoirs/ketels/radiat. centr. verwarm.

Vervaard. landbouwmach./-werkt.

Architecten-/ingenieurs-/ov. techn.ontw.-/teken-/adviesbur.

Vervaard. ov. mach./appar. voor specif. ind. activ.

Vervoer via pijpleidingen

BBL MKF Motorvoertuigen

Handel in/repar. auto's (1)

Handel in/repar. auto's (2)

Prod./distrib. elektriciteit/aardgas/stoom/warm water

Verhuur bouw-/sloopmachines met bedienend personeel

Expedit./cargad./bevracht.;weging/meting

BBL Specialist Energie- en informatietechniek

Bouwinstallatie

Vervaard. chem. prod.

Vervaard. non-ferrometalen

Vervaard. elektr. lampen/buizen/van verlichtingsbenodigdh.

Vervoer per spoor

Ov. dienstverl. tbv verv. n.e.g.

Vervaard. basischemicalien

BBL Specialist Installatie-, service- en onderhoudstechniek 
Tabel B3.5 (vervolg)

Belangrijkste bedrijfsgroepen waarin schoolverlaters werkzaam zijn

\section{BBL MKF Procestechniek}

Vervaard. chem. prod.

Vervaard. elektr. componenten

Vervaard. prod. kunststof

Vervaard. basischemicaliën

Vervaard. ov. voedingsmid.

Natuursteenbewerking

Vervaard. auto's

BBL MKF Automatisering

Systeemontwikkelings-/systeemanalyse-/programmeerdienst. 30

Overig onderwijs

Ov. dienstverl. op gebied automat.

Telecommunicatie

Adviesbur. op gebied automat./systeemh.

Speur-/ontwikkelingswerk

Overheidsdienst.

Gezondheidszorg

Welzijnszorg

BBL MKF Detailhandel/ambulante handel

Niet-gespec. detailh. in winkel

Ov. gespec. detailh. in winkel

BBL MKF Horeca, instellingskeuken en contractcatering

Restaurants/cafetaria's/snackbars e.d.

Hotels/pensions/conferentie-oorden

Cafes e.d.

BBL MKF Verpleging en verzorging

Gezondheidszorg

BBL ZB Uiterlijke verzorging

Ov. dienstverlening

Gezondheidszorg

BBL MKF Sociaal-pedagogisch werk 
Tabel B3.6

Belangrijkste beroepsgroepen waarin schoolverlaters werkzaam zijn

IVBO Landbouw en natuurlijke omgeving

Agrarische arbeider

Verkopers

Laders en lossers

Hulpkrachten horeca en verzorging

VBO Landbouw en natuurlijke omgeving

Verkopers

Agrarische arbeider

Hulpkrachten horeca en verzorging

Assembleurs

VBO Bouwtechniek

Bouwvakkers

Aannemers en installateurs

Assembleurs

VBO Mechanische techniek

Metaalarbeiders

Laders en lossers

Bouwvakkers

Assembleurs

Productiemedewerker

VBO Elektrotechniek

Monteurs en controleurs elektrotechnische producten

Bouwvakkers

Elektromonteurs

Chauffeurs

Interieurverzorger

Assembleurs

VBO Motorvoertuigentechniek

Monteurs

Assembleurs

Metaalarbeiders

Chauffeurs

Verkopers

VBO Consumptieve techniek

Hulpkrachten horeca en verzorging

Bakkers en slagers

Mechanisch operators

Laders en lossers

Vakkenvuller

Receptionisten en administratieve employés

VBO Administratie

Receptionisten en administratieve employés

Aspirant politieagenten, soldaten en beveiligingshulpkrachten 
Tabel B3.6 (vervolg)

Belangrijkste beroepsgroepen waarin schoolverlaters werkzaam zijn

\section{VBO Verkoop}

Verkopers

Kantoorhulpen, inpakkers en colporteurs

Aspirant politieagenten, soldaten en beveiligingshulpkrachten

\section{VBO Verzorging}

Verkopers

Hulpkrachten horeca en verzorging

Verpleeghulpen en leerling-verpleegkundigen

Mechanisch operators

\section{BOL BB Bloemschikken}

Verkopers

Agrarische vakkrachten

Productiemedewerker

Monteurs en controleurs elektrotechnische producten

Mechanisch operators

Agrarische arbeider

BOL BB Houtbewerking en woninginrichting

Aannemers en installateurs

Verkopers

Schoen- en kleermakers

Commercieel employés

Bouwvakkers

Chauffeurs

Hoofden technische dienst

Monteurs

BOL BB Bedrijfsadministratie

Boekhouders en secretaresses

Receptionisten en administratieve employés

Commercieel employés

BOL BB Beveiliging

Aspirant politieagenten, soldaten en beveiligingshulpkrachten

Chauffeurs

Laders en lossers

Bouwvakkers

Aannemers en installateurs

\section{BOL BB Secretarieel}

Receptionisten en administratieve employés $\quad 33$

Boekhouders en secretaresses $\quad 28$

$\begin{array}{ll}\text { Verkopers } & 13\end{array}$

Commercieel employés $\quad 6$

BOL BB Detailhandel/ambulante handel

Verkopers

Receptionisten en administratieve employés

Laders en lossers 
Tabel B3.6 (vervolg)

Belangrijkste beroepsgroepen waarin schoolverlaters werkzaam zijn

BOL BB Horeca, instellingskeuken en contractcatering

Verzorgend personeel

Verkopers

Hulpkrachten horeca en verzorging

Receptionisten en administratieve employés

Interieurverzorger

Mechanisch operators

Verpleeghulpen en leerling-verpleegkundigen

Hoofden technische dienst

BOL BB Verpleging en verzorging

Verpleeghulpen en leerling-verpleegkundigen $\quad 27$

Verzorgend personeel

Hulpkrachten horeca en verzorging 16

Verkopers

$\begin{array}{ll}\text { Verplegenden en doktersassistenten } & 5\end{array}$

BOL ZB Plantenteelt

Agrarische arbeider

Verkopers

Weg- en waterbouwkundige vakkrachten

Agrarische bedrijfshoofden

Landbouwmachinebestuurders en vissers

BOL ZB Veehouderij

Agrarische arbeider

Weg- en waterbouwkundige vakkrachten

Verkopers

Monteurs

Verplegenden en doktersassistenten

BOL ZB Bloemschikken

Verkopers

Agrarische vakkrachten

BOL ZB Groene ruimte

Agrarische bedrijfshoofden

\begin{tabular}{ll} 
Agrarische arbeider & 21 \\
\hline erkopers & 18
\end{tabular}

Verkopers 18

BOL KF Plantenteelt

Agrarische arbeider

Milieuhygienisten en agrarisch vertegenwoordigers

Commercieel employés

Agrarische vakkrachten

Verkopers

Agrarische bedrijfshoofden

\section{BOL KF Veehouderij}

Agrarische arbeider 
Tabel B3.6 (vervolg)

Belangrijkste beroepsgroepen waarin schoolverlaters werkzaam zijn

BOL KF Levensmiddelentechnologie

Laboranten

Procesoperators

Agrarische arbeider

Winkeliers

Activiteitenbegeleiders en medewerkers arbeidsbemiddeling

BOL KF Bloemschikken

Verkopers

Agrarische vakkrachten

Agrarische arbeider

Boekhouders en secretaresses

BOL KF Groene ruimte

Agrarische arbeider

Agrarische bedrijfshoofden

Weg- en waterbouwkundige arbeiders

Verkopers

BOL MKF Bouw

Aannemers en installateurs

Bouwvakkers

Commercieel employés

BOL MKF Houtbewerking en woninginrichting

Aannemers en installateurs

Commercieel employés

Schoen- en kleermakers

Monteurs

Verkopers

BOL MKF Grond-, water- en wegenbouw

Weg-en waterbouwkundige vakkrachten

Aannemers en installateurs

Weg- en waterbouwkundige arbeiders

BOL MKF Reclame, presentatie en communicatie

Technisch-commercieel employés

Aannemers en installateurs

Commercieel employés

Grafisch productiepersoneel

Grafisch ontwerpers

Winkeliers

\section{BOL MKF Werktuigbouwkunde}

Aannemers en installateurs

Bankwerkers en lassers 
Tabel B3.6 (vervolg)

Belangrijkste beroepsgroepen waarin schoolverlaters werkzaam zijn

BOL MKF Motorvoertuigen

Monteurs

Verkopers

Receptionisten en administratieve employés

Boekhouders en secretaresses

Winkeliers

BOL MKF Energie- en informatietechniek

Elektromonteurs

Monteurs

Programmeurs

Elektronicamonteurs

BOL MKF Informatietechniek

Programmeurs

Systeemanalisten

Elektronicamonteurs

Elektromonteurs

BOL MKF Grafische techniek, communicatie, audiovisueel

Grafisch ontwerpers

Grafisch productiepersoneel

Productieplanners

Grafische vakkrachten

Kunstenaars

BOL MKF Laboratoriumtechniek

Laboranten

Apothekersassistenten en medisch laboranten

BOL MKF Scheepvaart

Schippers en conducteurs

Monteurs

Weg- en waterbouwkundige vakkrachten

Chauffeurs

Vliegers, scheepskapiteins en leidinggevenden transport

BOL MKF Transport en logistiek

Administratieve transportemployes

Receptionisten en administratieve employés

Juridisch, bestuurlijk medewerkers

Sociaal-cultureel werkers

BOL MKF Bedrijfsadministratief

Boekhouders en secretaresses

Receptionisten en administratieve employés

Commercieel employes

Programmeurs

BOL MKF Commercieel

Commercieel employes

Boekhouders en secretaresses

Receptionisten en administratieve employés

Verkopers 
Tabel B3.6 (vervolg)

Belangrijkste beroepsgroepen waarin schoolverlaters werkzaam zijn

MKF Economisch-juridisch

Boekhouders en secretaresses

43

Commercieel employes

Receptionisten en administratieve employés

Administratieve transportemployes

Winkeliers

11

BOL MKF Secretarieel

Boekhouders en secretaresses

Receptionisten en administratieve employés

Commercieel employes

Medisch secretaresses

BOL MKF Detailhandel/ambulante handel

Verkopers

Winkeliers

Commercieel employes

Boekhouders en secretaresses

Receptionisten en administratieve employés

BOL MKF Horeca, instellingskeuken en contractcatering Hulpkrachten horeca en verzorging

Receptionisten en administratieve employés

Commercieel employes

Boekhouders en secretaresses

Verzorgend personeel

Bedrijfshoofden horeca

BOL MKF Toerisme, recreatie en reizen

Commercieel employes

Receptionisten en administratieve employés

Boekhouders en secretaresses

BOL MKF Assistenten gezondheidszorg

Verplegenden en doktersassistenten

BOL MKF Facilitaire dienstverlening

Hulpkrachten horeca en verzorging

Verkopers

Boekhouders en secretaresses

12

Bedrijfshoofden horeca

Aspirant politieagenten, soldaten en beveiligingshulpkrachten

Verzorgend personeel

BOL MKF Sport en bewegen

Sportinstructeurs

Activiteitenbegeleiders en medewerkers arbeidsbemiddeling 
Tabel B3.6 (vervolg)

Belangrijkste beroepsgroepen waarin schoolverlaters werkzaam zijn

BOL MKF Verpleging en verzorging

Verzorgend personeel

Verplegenden en doktersassistenten

Ziekenverzorgenden

Verpleeghulpen en leerling-verpleegkundigen

25

Hulpkrachten horeca en verzorging

BOL ZB Uiterlijke verzorging

Verzorgend personeel

Verkopers

Hulpkrachten horeca en verzorging

Receptionisten en administratieve employés

BOL MKF Sociaal-cultureel werker

Verzorgend personeel

Activiteitenbegeleiders en medewerkers arbeidsbemiddeling 18

Productiemedewerker

Apothekersassistenten en medisch laboranten

Winkeliers

Verplegenden en doktersassistenten

Receptionisten en administratieve employés

BOL MKF Sociaal-pedagogisch werk algemeen

Verzorgend personeel

Activiteitenbegeleiders en medewerkers arbeidsbemiddeling

Hulpkrachten horeca en verzorging

BOL MKF Sociaal-juridisch werk

Activiteitenbegeleiders en medewerkers arbeidsbemiddeling $\quad 25$

Boekhouders en secretaresses $\quad 16$

$\begin{array}{ll}\text { Receptionisten en administratieve employés } & 10\end{array}$

Commercieel employés

Verplegenden en doktersassistenten

BBL BB Bouw

Bouwvakkers

Aannemers en installateurs

BBL BB Constructie(bank)werken/(isolatie)plaatwerken/pijpenbew.

Metaalarbeiders

Bankwerkers en lassers

Bouwvakkers

Aannemers en installateurs

Monteurs

Productiemedewerker

BBL BB Machinebankwerken/verspanen

Metaalarbeiders

Bankwerkers en lassers

Productiemedewerker

Laders en lossers 
Tabel B3.6 (vervolg)

Belangrijkste beroepsgroepen waarin schoolverlaters werkzaam zijn

BBL BB Wegvervoer

Chauffeurs

81

Laders en lossers

BBL BB Detailhandel/ambulante handel

Verkopers

Mechanisch operators

10

Receptionisten en administratieve employés

BBL BB Horeca, instellingskeuken en contractcatering

Hulpkrachten horeca en verzorging

Verzorgend personeel

BBL BB Facilitaire dienstverlening

Hulpkrachten horeca en verzorging

Verkopers

BBL BB Verpleging en verzorging

Ziekenverzorgenden

Hulpkrachten horeca en verzorging

Verpleeghulpen en leerling-verpleegkundigen

Verzorgend personeel

BBL MKF Bouw

Aannemers en installateurs

Bouwvakkers

BBL ZB Grond-, water- en wegenbouw

Weg- en waterbouwkundige arbeiders

Weg- en waterbouwkundige vakkrachten

Chauffeurs

BBL ZB Contructie(bank)werken/(isolatie)plaatwerken/pijpenbew.

Metaalarbeiders

Aannemers en installateurs

25

Monteurs

Productieplanners

16

Bankwerkers en lassers

Bouwvakkers

Procesoperators

BBL MKF Motorvoertuigen

Monteurs

BBL Specialist Energie- en informatietechniek

Monteurs

Elektronicamonteurs

Elektromonteurs

Monteurs en controleurs elektrotechnische producten

Assembleurs

Productieplanners 
Tabel B3.6 (vervolg)

Belangrijkste beroepsgroepen waarin schoolverlaters werkzaam zijn

BBL Specialist Installatie-, service- en onderhoudstechniek

Aannemers en installateurs

Bouwvakkers

Monteurs

BBL MKF Procestechniek

Procesoperators

Monteurs

Programmeurs

Mechanisch operators

Productieplanners

Bankwerkers en lassers

Elektromonteurs

BBL MKF Automatisering

Programmeurs

Systeemanalisten

Productieplanners

Organisatie-adviseurs

BBL MKF Detailhandel/ambulante handel

Winkeliers

Verkopers

Receptionisten en administratieve employés

BBL MKF Horeca, instellingskeuken en contractcatering

Verzorgend personeel

Hulpkrachten horeca en verzorging

Cafe- en snackbarhouders

BBL MKF Verpleging en verzorging

Verplegenden en doktersassistenten

Verzorgend personeel

Ziekenverzorgenden

Sociaal-cultureel werkers

BBL ZB Uiterlijke verzorging

\begin{tabular}{ll} 
Hulpkrachten horeca en verzorging & 67 \\
\hline
\end{tabular}

Verzorgend personeel

BBL MKF Sociaal-pedagogisch werk

Verzorgend personeel

Activiteitenbegeleiders en medewerkers arbeidsbemiddeling

Hulpkrachten horeca en verzorging

Zie ook toelichting bladzijde 40 
Tabel B3.7

Grootte van de organisatie waarin schoolverlaters werkzaam zijn

\begin{tabular}{|c|c|c|c|c|c|}
\hline \multirow[t]{2}{*}{ Opleidingsrichting } & \multirow{2}{*}{$\begin{array}{r}1 \text { pers } \\
\\
\% \\
\end{array}$} & $\begin{array}{r}2 \mathrm{t} / \mathrm{m} 9 \\
\text { pers }\end{array}$ & \multicolumn{2}{|c|}{$\begin{array}{r}10 \mathrm{t} / \mathrm{m} \quad 100 \mathrm{t} / \mathrm{m} \\
99 \text { pers } 999 \text { pers }\end{array}$} & \\
\hline & & $\%$ & $\%$ & $\%$ & \\
\hline \multicolumn{6}{|l|}{ VBO } \\
\hline IVBO Landbouw en natuurlijke omgeving & 0 & 22 & 47 & 1 & \\
\hline Landbouw en natuurlijke omgeving & 1 & 39 & 32 & 1 & \\
\hline Bouwtechniek & 3 & 27 & 51 & 1 & \\
\hline Mechanische techniek & 0 & 27 & 39 & 1 & \\
\hline Elektrotechniek & 5 & 7 & 75 & & \\
\hline Motorvoertuigentechniek & 0 & 11 & 67 & 2 & \\
\hline Consumptieve techniek & 0 & 12 & 60 & 1 & \\
\hline Administratie & 0 & 7 & 41 & 1 & \\
\hline Verkoop & 0 & 28 & 23 & 1 & \\
\hline Verzorging & 0 & 23 & 41 & 2 & \\
\hline
\end{tabular}

BOL niveau $1 / 2$

BB Bloemschikken

BB Houtbewerking en woninginrichting

BB Bedrijfsadministratie

BB Beveiliging

BB Secretarieel

BB Detailhandel/ambulante handel

BB Horeca, instellingskeuken en contractcatering

BB Verpleging en verzorging

\section{$\%$}

$$
17
$$

15

13$$
12
$$$$
42
$$$$
30
$$

BOL niveau $3 / 4$

ZB Plantenteelt

ZB Veehouderij

ZB Bloemschikken

ZB Groene ruimte

KF Plantenteelt

KF Veehouderij

KF Levensmiddelentechnologie

KF Bloemschikken

KF Groene ruimte

MKF Bouw

MKF Houtbewerking en woninginrichting

MKF Grond-, water- en wegenbouw

MKF Reclame, presentatie en communicatie

MKF Werktuigbouwkunde

MKF Motorvoertuigen

MKF Energie- en informatietechniek

MKF Informatietechniek

MKF Grafische techniek, communicatie, audiovisueel

MKF Laboratoriumtechniek

MKF Scheepvaart

MKF Transport en logistiek

MKF Bedrijfsadministratief

MKF Commercieel

MKF Economisch-juridisch

MKF Secretarieel

MKF Detailhandel/ambulante handel

MKF Horeca, instellingskeuken en contractcatering

MKF Toerisme, recreatie en reizen

MKF Assistenten gezondheidszorg

$\begin{array}{rrrrr}0 & 45 & 30 & 16 & 10 \\ 0 & 34 & 47 & 13 & 6 \\ 0 & 16 & 38 & 29 & 18 \\ 0 & 5 & 10 & 22 & 63 \\ 0 & 9 & 33 & 30 & 28 \\ 1 & 15 & 29 & 28 & 28 \\ 0 & 26 & 37 & 21 & 16 \\ 0 & 9 & 29 & 41 & 21\end{array}$


Tabel B3.7 (vervolg)

Grootte van de organisatie waarin schoolverlaters werkzaam zijn

\begin{tabular}{|c|c|c|c|c|c|}
\hline \multirow[t]{2}{*}{ Opleidingsrichting } & 1 pers & $\begin{array}{r}2 \mathrm{t} / \mathrm{m} 9 \\
\text { pers }\end{array}$ & $\begin{array}{r}10 \mathrm{t} / \mathrm{m} \\
99 \text { pers }\end{array}$ & $\begin{array}{r}100 \mathrm{t} / \mathrm{m} \\
999 \mathrm{pers}\end{array}$ & $\begin{aligned}> & 1000 \\
& \text { pers }\end{aligned}$ \\
\hline & $\%$ & $\%$ & $\%$ & $\%$ & $\%$ \\
\hline
\end{tabular}

BOL niveau $3 / 4$ (vervolg)

$\begin{array}{llllll}\text { MKF Facilitaire dienstverlening } & 0 & 8 & 33 & 25 & 33\end{array}$

$\begin{array}{llllll}\text { MKF Sport en bewegen } & 1 & 12 & 43 & 21 & 22\end{array}$

$\begin{array}{llllll}\text { MKF Verpleging en verzorging } & 0 & 3 & 11 & 49 & 37\end{array}$

ZB Uiterlijke verzorging $\quad \begin{array}{llllll} & 1 & 62 & 24 & 0 & 12\end{array}$

MKF Sociaal-cultureel werker $\quad \begin{array}{llllll} & 0 & 8 & 40 & 37 & 15\end{array}$

$\begin{array}{llllll}\text { MKF Sociaal-pedagogisch werk algemeen } & 0 & 9 & 33 & 38 & 21\end{array}$

MKF Sociaal-juridisch werk

$\begin{array}{lll}22 & 37 & 36\end{array}$

BBL niveau $1 / 2$

BB Bouw

BB Constructie(bank)werken/(isolatie)plaatwerken/pijpenbew.

BB Machinebankwerken/verspanen

BB Wegvervoer

BB Detailhandel/ambulante handel

BB Horeca, instellingskeuken en contractcatering

BB Facilitaire dienstverlening

BB Verpleging en verzorging

BBL niveau 3/4

MKF Bouw

ZB Grond-, water- en wegenbouw

ZB Contructie(bank)werken/(isolatie)plaatwerken/pijpenbew.

MKF Motorvoertuigen

Specialist Energie- en informatietechniek

Specialist Installatie-, service- en onderhoudstechniek

MKF Procestechniek

MKF Automatisering

MKF Detailhandel/ambulante handel

MKF Horeca, instellingskeuken en contractcatering

MKF Verpleging en verzorging

ZB Uiterlijke verzorging

MKF Sociaal-pedagogisch werk

$\begin{array}{rrrrr}1 & 27 & 44 & 26 & 2 \\ 0 & 16 & 39 & 25 & 20 \\ 0 & 9 & 60 & 19 & 12 \\ 0 & 6 & 66 & 21 & 8 \\ 0 & 28 & 31 & 10 & 31 \\ 0 & 14 & 57 & 14 & 14 \\ 0 & 0 & 35 & 37 & 28 \\ 0 & 0 & 5 & 77 & 18\end{array}$

Zie ook toelichting bladzijde 42 
Tabel B3.8

Beloning van werkende schoolverlaters

\begin{tabular}{lrr} 
Opleidingsrichting & $\begin{array}{r}\text { gemiddeld bruto } \\
\text { maandloon }\end{array}$ & $\begin{array}{r}\text { gemiddeld bruto } \\
\text { uurloon }\end{array}$ \\
& guldens & guldens \\
\hline VBO & & \\
IVBO Landbouw en natuurlijke omgeving & 1.214 & 8,72 \\
Landbouw en natuurlijke omgeving & 1.134 & 8,23 \\
Bouwtechniek & 1.654 & 10,77 \\
Mechanische techniek & 1.206 & 7,93 \\
Elektrotechniek & 1.404 & 9,12 \\
Motorvoertuigentechniek & 1.084 & 7,36 \\
Consumptieve techniek & 1.599 & 10,84 \\
Administratie & 1.397 & 8,60 \\
Verkoop & 1.182 & 8,47 \\
Verzorging & 1.212 & 8,85
\end{tabular}

BOL niveau $1 / 2$

BB Bloemschikken

$1.568 \quad 11,13$

BB Bedrijfsadministratie

2.236

13,76

BB Secretarieel

$2.527 \quad 15,94$

BB Detailhandel/ambulante handel

$1.801-12,53$

BB Horeca, instellingskeuken en contractcatering

12,07

BB Verpleging en verzorging

$1.696 \quad 14,63$

BOL niveau $3 / 4$

ZB Plantenteelt

ZB Veehouderij

ZB Bloemschikken

1.927

13,99
12,02

ZB Groene ruimte

2.701

17,77
18,74

KF Plantenteelt

3.204

KF Veehouderij

16,28

KF Bloemschikken

2.563

KF Groene ruimte

$\begin{array}{ll}2.861 & 17,54 \\ 3.154 & 18,91\end{array}$

MKF Bouw

MKF Houtbewerking en woninginrichting

19,01

MKF Grond-, water- en wegenbouw

3.051

19,01

MKF Reclame, presentatie en communicatie

18,37

MKF Werktuigbouwkunde

MKF Motorvoertuigen

19,07
17,50

MKF Energie- en informatietechniek

19,51

MKF Informatietechniek

19,51
18,89

MKF Grafische techniek, communicatie, audiovisueel

19,38

MKF Laboratoriumtechniek

20,43

MKF Scheepvaart

MKF Transport en logistiek

20,37

MKF Bedrijfsadministratief

18,51

MKF Commercieel

MKF Economisch-juridisch

MKF Secretariee

16,15

16,40

15,36

16,27

MKF Detailhandel/ambulante handel

MKF Horeca, instellingskeuken en contractcatering

19,78

MKF Toerisme, recreatie en reizen

17,38

MKF Assistenten gezondheidszorg

16,36

MKF Facilitaire dienstverlening

16,17

MKF Sport en bewegen

21,78

MKF Verpleging en verzorging 
Tabel B3.8 (vervolg)

Beloning van werkende schoolverlaters

\begin{tabular}{rrr} 
Opleidingsrichting & $\begin{array}{r}\text { gemiddeld bruto } \\
\text { maandloon }\end{array}$ & $\begin{array}{r}\text { gemiddeld bruto } \\
\text { uurloon }\end{array}$ \\
& guldens & guldens \\
\hline
\end{tabular}

BOL niveau 3/4 (vervolg)

ZB Uiterlijke verzorging

MKF Sociaal-cultureel werker

rand

MKF Sociaal-pedagogisch we

MKF Sociaal-juridisch werk

$\begin{array}{ll}2.315 & 18,37 \\ 2.929 & 20,92\end{array}$

BBL niveau $1 / 2$

BB Bouw

BB Constructie(bank)werken/(isolatie)plaatwerken/pijpenbew.

BB Machinebankwerken/verspanen

BB Wegvervoer

2.998

13,59

BB Detailhandel/ambulante handel

1.697

16,65

BB Horeca, instellingskeuken en contractcatering

2.274

11,75

BB Facilitaire dienstverlening

2.318

15,42

BB Verpleging en verzorging

2.581

19,12

BBL niveau $3 / 4$

MKF Bouw

MKF Motorvoertuigen

MKF Procestechniek

MKF Detailhandel/ambulante handel

MKF Horeca, instellingskeuken en contractcatering

MKF Verpleging en verzorging

2.204

19,32

19,32
23,90

MKF Sociaal-pedagogisch werk

18,70

Zie ook toelichting bladzijde 44 
Tabel B3.9

Vereist opleidingsniveau voor de huidige functie volgens de werkgever

\begin{tabular}{|c|c|c|c|}
\hline \multirow[t]{2}{*}{ Opleidingsrichting } & \multirow{2}{*}{$\begin{array}{r}\text { lager } \\
\quad \%\end{array}$} & \multirow{2}{*}{$\begin{array}{r}\text { zelfde } \\
\% \\
\end{array}$} & \multirow{2}{*}{$\begin{array}{r}\text { hoger } \\
\% \\
\end{array}$} \\
\hline & & & \\
\hline \multicolumn{4}{|l|}{ Vво } \\
\hline IVBO Landbouw en natuurlijke omgeving & 46 & 49 & 5 \\
\hline Landbouw en natuurlijke omgeving & 26 & 64 & 10 \\
\hline Bouwtechniek & 31 & 61 & 8 \\
\hline Mechanische techniek & 28 & 72 & \\
\hline Elektrotechniek & 37 & 54 & 9 \\
\hline Motorvoertuigentechniek & 28 & 72 & \\
\hline Consumptieve techniek & 42 & 38 & 19 \\
\hline Administratie & 33 & 47 & 21 \\
\hline Verkoop & 37 & 59 & 4 \\
\hline Verzorging & 15 & 78 & 7 \\
\hline \multicolumn{4}{|l|}{ BOL niveau $1 / 2$} \\
\hline BB Bloemschikken & 67 & 20 & 13 \\
\hline BB Bedrijfsadministratie & 23 & 32 & 45 \\
\hline BB Beveiliging & 84 & & 16 \\
\hline BB Secretarieel & 40 & 18 & 42 \\
\hline BB Detailhandel/ambulante handel & 62 & 19 & 19 \\
\hline BB Horeca, instellingskeuken en contractcatering & 40 & 35 & 25 \\
\hline BB Verpleging en verzorging & 53 & 20 & 27 \\
\hline
\end{tabular}

BOL niveau 3/4

ZB Plantenteelt

ZB Veehouderij

ZB Bloemschikken

ZB Groene ruimte

KF Plantenteelt

KF Veehouderij

KF Levensmiddelentechnologie

KF Bloemschikken

KF Groene ruimte

MKF Bouw

MKF Houtbewerking en woninginrichting

MKF Grond-, water- en wegenbouw

MKF Reclame, presentatie en communicatie

MKF Werktuigbouwkunde

MKF Motorvoertuigen

MKF Energie- en informatietechniek

MKF Informatietechniek

MKF Grafische techniek, communicatie, audiovisueel

8

MKF Laboratoriumtechniek

MKF Scheepvaart

MKF Transport en logistiek

MKF Bedrijfsadministratief

MKF Commercieel

MKF Economisch-juridisch

MKF Secretarieel

MKF Detailhandel/ambulante handel

MKF Horeca, instellingskeuken en contractcatering

MKF Toerisme, recreatie en reizen

MKF Assistenten gezondheidszorg

MKF Facilitaire dienstverlening

MKF Sport en bewegen 
Tabel B3.9 (vervolg)

Vereist opleidingsniveau voor de huidige functie volgens de werkgever

\begin{tabular}{rrrr} 
Opleidingsrichting & lager & zelfde & hoger \\
& $\%$ & $\%$ & $\%$ \\
\hline
\end{tabular}

BOL niveau 3/4 (vervolg)

MKF Verpleging en verzorging $\quad 21 \quad 78 \quad 1$

ZB Uiterlijke verzorging

MKF Sociaal-cultureel werker

MKF Sociaal-pedagogisch werk algemeen

MKF Sociaal-juridisch werk

$78 \quad 1$

BBL niveau $1 / 2$

BB Bouw

$\begin{array}{lrr}59 & 30 & 11 \\ 55 & 34 & 11 \\ 57 & 22 & 21 \\ 70 & 9 & 21 \\ 87 & 4 & 9 \\ 48 & 22 & 30 \\ 37 & 40 & 23 \\ 43 & 8 & 49\end{array}$

Constructie(bank)werken/(isolatie)plaatwerken/pijpenbew.

BB Machinebankwerken/verspanen

BB Wegvervoer

BB Detailhandel/ambulante handel

BB Horeca, instellingskeuken en contractcatering

BB Facilitaire dienstverlening

BB Verpleging en verzorging

BBL niveau 3/4

MKF Bouw

$72 \quad 28$

ZB Grond-, water- en wegenbouw

ZB Contructie(bank)werken/(isolatie)plaatwerken/pijpenbew.

MKF Motorvoertuigen

Specialist Energie- en informatietechniek

Specialist Installatie-, service- en onderhoudstechniek

MKF Procestechniek

MKF Automatisering

MKF Detailhandel/ambulante handel

MKF Horeca, instellingskeuken en contractcatering

MKF Verpleging en verzorging

MKF Sociaal-pedagogisch werk

\section{1}

Zie ook toelichting bladzijde 45 
Tabel B3.10

Vereiste opleidingsrichting voor de huidige functie volgens de werkgever

\begin{tabular}{lccc} 
Opleidingsrichting & $\begin{array}{r}\text { eigen/ } \\
\text { verwante } \\
\text { richting }\end{array}$ & $\begin{array}{r}\text { andere } \\
\text { richting }\end{array}$ & $\begin{array}{r}\text { geen } \\
\text { richting }\end{array}$ \\
& $\%$ & $\%$ & \\
\hline VBO & & & \\
IVBO Landbouw en natuurlijke omgeving & 38 & & 62 \\
Landbouw en natuurlijke omgeving & 46 & 6 & 48 \\
Bouwtechniek & 70 & 3 & 28 \\
Mechanische techniek & 55 & 9 & 36 \\
Elektrotechniek & 57 & 4 & 39 \\
Motorvoertuigentechniek & 72 & 11 & 17 \\
Consumptieve techniek & 69 & 8 & 23 \\
Administratie & 19 & 7 & 74 \\
Verkoop & 29 & 6 & 65 \\
Verzorging & 52 & 4 & 44
\end{tabular}

BOL niveau $1 / 2$

BB Bloemschikken

BB Houtbewerking en woninginrichting

BB Bedrijfsadministratie

BB Beveiliging

BB Secretarieel

BB Detailhandel/ambulante handel

BB Horeca, instellingskeuken en contractcatering

BB Verpleging en verzorging

BOL niveau $3 / 4$

ZB Plantenteelt

ZB Veehouderij

ZB Bloemschikken

ZB Groene ruimte

KF Plantenteelt

KF Veehouderij

KF Levensmiddelentechnologie

KF Bloemschikken

KF Groene ruimte

MKF Bouw

MKF Houtbewerking en woninginrichting

MKF Grond-, water- en wegenbouw

MKF Reclame, presentatie en communicatie

MKF Werktuigbouwkunde

MKF Motorvoertuigen

MKF Energie- en informatietechniek

MKF Informatietechniek

MKF Grafische techniek, communicatie, audiovisueel

MKF Laboratoriumtechniek

MKF Scheepvaart

MKF Transport en logistiek

MKF Bedrijfsadministratief

MKF Commercieel

MKF Economisch-juridisch

MKF Secretarieel

MKF Detailhandel/ambulante handel

MKF Horeca, instellingskeuken en contractcatering

MKF Toerisme, recreatie en reizen

$\begin{array}{rrr}68 & 1 & 31 \\ 52 & 9 & 39 \\ 72 & 4 & 24 \\ 73 & 2 & 25 \\ 69 & 8 & 23 \\ 49 & 7 & 44 \\ 60 & 11 & 29 \\ 81 & 2 & 17 \\ 80 & 6 & 14 \\ 79 & 6 & 15 \\ 68 & 8 & 24 \\ 86 & 5 & 9 \\ 59 & 5 & 35 \\ 81 & 2 & 17 \\ 82 & & 18 \\ 83 & 3 & 14 \\ 77 & & 23 \\ 85 & 3 & 12 \\ 91 & & 9 \\ 87 & 3 & 10 \\ 42 & 18 & 40 \\ 74 & 3 & 23 \\ 61 & 8 & 31 \\ 63 & 19 & 19 \\ 74 & 6 & 20 \\ 49 & 4 & 46 \\ 69 & 8 & 23 \\ 81 & 5 & 14\end{array}$


Tabel B3.10 (vervolg)

Vereiste opleidingsrichting voor de huidige functie volgens de werkgever

\begin{tabular}{rrrr} 
Opleidingsrichting & $\begin{array}{r}\text { eigen/ } \\
\text { verwante } \\
\text { richting }\end{array}$ & $\begin{array}{r}\text { andere } \\
\text { richting }\end{array}$ & $\begin{array}{r}\text { geen } \\
\text { richting }\end{array}$ \\
& $\%$ & $\%$ & $\%$ \\
\hline
\end{tabular}

BOL niveau 3/4 (vervolg)

$\begin{array}{llll}\text { MKF Assistenten gezondheidszorg } & 91 & 1 & 7\end{array}$

MKF Facilitaire dienstverlening $\quad 44 \quad 48$

$\begin{array}{llll}\text { MKF Sport en bewegen } & 70 & 7 & 23\end{array}$

$\begin{array}{llll}\text { MKF Verpleging en verzorging } & 91 & 1 & 7\end{array}$

ZB Uiterlijke verzorging $\quad 66 \quad 25$

MKF Sociaal-cultureel werker $\quad 69 \quad 56$

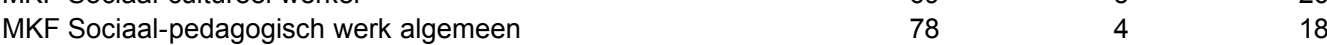

MKF Sociaal-juridisch werk 56

$16-29$

BBL niveau $1 / 2$

BB Bouw

BB Constructie(bank)werken/(isolatie)plaatwerken/pijpenbew. 57

4

BB Machinebankwerken/verspanen

BB Wegvervoer

BB Detailhandel/ambulante handel

BB Horeca, instellingskeuken en contractcatering

BB Facilitaire dienstverlening

BB Verpleging en verzorging $\%$

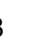

BBL niveau $3 / 4$

MKF Bouw

ZB Grond-, water- en wegenbouw

ZB Contructie(bank)werken/(isolatie)plaatwerken/pijpenbew.

MKF Motorvoertuigen

Specialist Energie- en informatietechniek

Specialist Installatie-, service- en onderhoudstechniek

MKF Procestechniek

MKF Automatisering

MKF Detailhandel/ambulante handel

MKF Horeca, instellingskeuken en contractcatering

MKF Verpleging en verzorging

ZB Uiterlijke verzorging

MKF Sociaal-pedagogisch werk

$57 \quad 10 \quad 33$

88

$61 \quad 39$

$19-15-65$

$57 \quad 11 \quad 32$

$73-5-23$

$\begin{array}{lll}70 & 4 & 26\end{array}$

Zie ook toelichting bladzijde 47 
Tabel B3.11

Gewenste en feitelijke wekelijkse arbeidsduur van werkende schoolverlaters

Opleidingsrichting

gewenste

wekelijkse

arbeidsduur feitelijke

wekelijkse

arbeidsduur

VBO

IVBO Landbouw en natuurlijke omgeving

uren

uren

Landbouw en natuurlijke omgeving

34,4

36,0

41,8

Bouwtechniek

Mechanische techniek

39,6

35,9

Elektrotechniek

38,9

34,5

Motorvoertuigentechniek

39,4

35,3

Consumptieve techniek

35,9

34,2

Administratie

36,6

33,7

Verkoop

33,1

35,0

Verzorging

BOL niveau $1 / 2$

BB Bloemschikken

BB Bedrijfsadministratie

BB Secretariee

BB Horeca, instellingskeuken en contractcatering

BOL niveau 3/4

ZB Plantenteelt

ZB Veehouderij

ZB Bloemschikken

ZB Groene ruimte

37,3

40,5

KF Plantenteelt

45,3

36,6

KF Veehouderij

$42,9 \quad 42,7$

$42,6 \quad 45,9$

KF Levensmiddelentechnologie

KF Bloemschikken

KF Groene ruimte

MKF Bouw

MKF Houtbewerking en woninginrichting

MKF Grond-, water- en wegenbouw

MKF Reclame, presentatie en communicatie

41,3

MKF Werktuigbouwkunde

MKF Motorvoertuigen

MKF Energie- en informatietechniek

MKF Informatietechniek

$40,8 \quad 40,2$

MKF Grafische techniek, communicatie, audiovisueel

MKF Laboratoriumtechniek

$\begin{array}{ll}41,6 & 40,2 \\ 37,5 & 37,1\end{array}$

MKF Scheepvaart

MKF Transport en logistiek

MKF Bedrijfsadministratief

MKF Commercieel

MKF Economisch-juridisch

MKF Secretarieel

MKF Detailhandel/ambulante handel 
Tabel B3.11 (vervolg)

Gewenste en feitelijke wekelijkse arbeidsduur van werkende schoolverlaters

Opleidingsrichting

gewenste

wekelijkse

arbeidsduur feitelijke

wekelijkse arbeidsduur

uren

uren

BOL niveau 3/4 (vervolg)

MKF Assistenten gezondheidszorg $\quad 35,4$

MKF Facilitaire dienstverlening $\quad 36,0$

37,2

35,6

MKF Sport en bewegen

37,2
33,6

MKF Verpleging en verzorging

36,1

37,4

MKF Sociaal-cultureel werker

33,8

34,5

33,3

35,4

MKF Social-cultureel werker

MKF Sociaal-juridisch werk

32,6

35,5

36,7

30,9

34,9

BBL niveau 1/2

BB Bouw

40,6

37,3

BB Constructie(bank)werken/(isolatie)plaatwerken/pijpenbew.

40,9

39,0

BB Machinebankwerken/verspanen

41,2

38,4

BB Wegvervoer

50,1

39,8

BB Detailhandel/ambulante handel

33,9

33,4

BB Horeca, instellingskeuken en contractcatering

36,7

34,1

BB Facilitaire dienstverlening

31,4

29,1

$B B$ Verpleging en verzorging

BBL niveau $3 / 4$

MKF Bouw

40,0

39,4

ZB Grond-, water- en wegenbouw

35,7

39,8

ZB Contructie(bank)werken/(isolatie)plaatwerken/pijpenbew.

37,8

38,9

MKF Motorvoertuigen

38,9

39,1

Specialist Energie- en informatietechniek

37,3

35,6

Specialist Installatie-, service- en onderhoudstechniek

39,5

MKF Procestechniek

38,2

37,2

MKF Automatisering

36,7

36,3

MKF Detailhandel/ambulante handel

37,1

$37,2 \quad 37,0$

MKF Horeca, instellingskeuken en contractcatering

38,8

MKF Verpleging en verzorging

32,1

ZB Uiterlijke verzorging

MKF Sociaal-pedagogisch werk

Zie ook toelichting bladzijde 49 
Tabel B3.12

Oordeel van de werkende schoolverlaters over de aansluiting tussen de afgesloten opleiding en de huidige functie

\begin{tabular}{|c|c|c|c|c|}
\hline \multirow[t]{2}{*}{ Opleidingsrichting } & \multirow{2}{*}{$\begin{array}{r}\text { goed } \\
\% \\
\end{array}$} & $\begin{array}{r}\text { vol- } \\
\text { doende }\end{array}$ & \multirow{2}{*}{$\begin{array}{r}\text { matig } \\
\\
\% \\
\end{array}$} & \multirow{2}{*}{$\begin{array}{r}\text { slecht } \\
\% \\
\end{array}$} \\
\hline & & $\%$ & & \\
\hline \multicolumn{5}{|l|}{ VBO } \\
\hline IVBO Landbouw en natuurlijke omgeving & 52 & 20 & 7 & 21 \\
\hline Landbouw en natuurlijke omgeving & 44 & 15 & 10 & 31 \\
\hline \multicolumn{5}{|l|}{ BOL niveau $1 / 2$} \\
\hline BB Bloemschikken & 28 & 40 & 16 & 16 \\
\hline BB Houtbewerking en woninginrichting & 51 & 34 & & 15 \\
\hline BB Bedrijfsadministratie & 51 & 22 & 16 & 11 \\
\hline BB Beveiliging & 44 & 31 & 5 & 20 \\
\hline BB Secretarieel & 39 & 32 & 11 & 18 \\
\hline BB Detailhandel/ambulante handel & 55 & 16 & 15 & 13 \\
\hline BB Horeca, instellingskeuken en contractcatering & 70 & 20 & 10 & \\
\hline BB Verpleging en verzorging & 62 & 16 & 5 & 17 \\
\hline
\end{tabular}

BOL niveau $3 / 4$

ZB Plantenteelt

ZB Veehouderij

ZB Bloemschikken

ZB Groene ruimte

KF Plantenteelt

KF Veehouderij

KF Bloemschikken

KF Groene ruimte

MKF Bouw

MKF Houtbewerking en woninginrichting

MKF Grond-, water- en wegenbouw

MKF Reclame, presentatie en communicatie

MKF Werktuigbouwkunde

MKF Motorvoertuigen

MKF Energie- en informatietechniek

MKF Informatietechniek

MKF Grafische techniek, communicatie, audiovisueel

MKF Laboratoriumtechniek

MKF Scheepvaart

MKF Transport en logistiek

MKF Bedrijfsadministratief

MKF Commercieel

MKF Economisch-juridisch

MKF Secretarieel

MKF Detailhandel/ambulante handel

MKF Horeca, instellingskeuken en contractcatering

MKF Toerisme, recreatie en reizen

MKF Assistenten gezondheidszorg

MKF Facilitaire dienstverlening

MKF Sport en bewegen

MKF Verpleging en verzorging

ZB Uiterlijke verzorging

MKF Sociaal-cultureel werker

MKF Sociaal-pedagogisch werk algemeen

MKF Sociaal-juridisch werk

$\begin{array}{rrrr}53 & 30 & 8 & 9 \\ 46 & 27 & 19 & 8 \\ 52 & 26 & 13 & 9 \\ 56 & 35 & 5 & 4 \\ 48 & 34 & 12 & 7 \\ 35 & 33 & 15 & 17 \\ 61 & 22 & 10 & 7 \\ 45 & 40 & 8 & 7 \\ 41 & 42 & 15 & 3 \\ 48 & 33 & 10 & 9 \\ 41 & 41 & 14 & 5 \\ 30 & 43 & 8 & 19 \\ 41 & 44 & 10 & 5 \\ 53 & 36 & 4 & 6 \\ 45 & 33 & 17 & 5 \\ 50 & 35 & 15 & \\ 50 & 36 & 10 & 4 \\ 49 & 29 & 17 & 5 \\ 51 & 26 & 16 & 8 \\ 29 & 71 & & \\ 43 & 35 & 16 & 6 \\ 40 & 41 & 11 & 8 \\ 25 & 46 & 18 & 11 \\ 50 & 37 & 8 & 5 \\ 36 & 40 & 15 & 9 \\ 50 & 28 & 18 & 5 \\ 45 & 34 & 12 & 9 \\ 67 & 25 & 5 & 4 \\ 42 & 38 & 8 & 13 \\ 68 & 9 & 7 & 16 \\ 59 & 31 & 8 & 3 \\ 62 & 9 & 7 & 22 \\ 25 & 39 & 15 & 21 \\ 51 & 30 & 9 & 10 \\ 42 & 34 & 6 & 18\end{array}$


Tabel B3.12 (vervolg)

Oordeel van de werkende schoolverlaters over de aansluiting tussen de afgesloten opleiding en de huidige functie

\begin{tabular}{lrrrr}
\hline Opleidingsrichting & goed & $\begin{array}{r}\text { vol- } \\
\text { doende }\end{array}$ & matig & slecht \\
& $\%$ & $\%$ & $\%$ & $\%$ \\
\hline
\end{tabular}

BBL niveau $1 / 2$

BB Bouw

BB Constructie(bank)werken/(isolatie)plaatwerken/pijpenbew.

BB Machinebankwerken/verspanen

BB Wegvervoer

BB Detailhandel/ambulante handel

BB Horeca, instellingskeuken en contractcatering

BB Facilitaire dienstverlening

BB Verpleging en verzorging

$\begin{array}{rrrr}71 & 20 & 4 & 5 \\ 49 & 38 & 11 & 2 \\ 75 & 13 & 6 & 6 \\ 68 & 30 & & 2 \\ 56 & 37 & 4 & 4 \\ 57 & 29 & 11 & 4 \\ 33 & 47 & 19 & 0 \\ 66 & 21 & 8 & 4\end{array}$

BBL niveau $3 / 4$

MKF Bouw

$\begin{array}{rrrr}73 & 24 & 3 & \\ 65 & 31 & & 4 \\ 29 & 46 & 19 & 6 \\ 74 & 22 & 5 & \\ 24 & 57 & 19 & \\ 54 & 42 & 4 & \\ 30 & 40 & 25 & 5 \\ 47 & 29 & 11 & 13 \\ 56 & 36 & 6 & 2 \\ 59 & 35 & 4 & 3 \\ 50 & 38 & 6 & 6 \\ 63 & 24 & 10 & 3\end{array}$

ZB Contructie(bank)werken/(isolatie)plaatwerken/pijpenbew.

MKF Motorvoertuigen

Specialist Energie- en informatietechniek

Specialist Installatie-, service- en onderhoudstechniek

MKF Procestechniek

MKF Detailhandel/ambulante handel

MKF Horeca, instellingskeuken en contractcatering

MKF Verpleging en verzorging

ZB Uiterlijke verzorging

MKF Sociaal-pedagogisch werk

63

Zie ook toelichting bladzijde 50 
Tabel B3.13

Percentage werkende schoolverlaters dat op zoek is naar een andere baan

VBO

IVBO Landbouw en natuurlijke omgeving

Landbouw en natuurlijke omgeving $\quad 15$

Bouwtechniek 15

Mechanische techniek $\quad 12$

Elektrotechniek

Motorvoertuigentechniek $\quad 28$

Consumptieve techniek

$\begin{array}{ll}\text { Administratie } & 35 \\ \text { Verkop } & 35\end{array}$

Verkoop

$\begin{array}{ll}\text { Verzorging } & 15\end{array}$

BOL niveau $1 / 2$

BB Bloemschikken

BB Houtbewerking en woninginrichting $\quad 19$

$\begin{array}{ll}\text { BB Bedrijfsadministratie } & 27\end{array}$

BB Beveiliging $\quad 22$

BB Secretarieel $\quad 26$

BB Detailhandel/ambulante handel 33

BB Horeca, instellingskeuken en contractcatering $\quad 45$

BB Verpleging en verzorging $\quad 10$

BOL niveau $3 / 4$

ZB Plantenteelt

ZB Vechoud

ZB Bloemschikken

ZB Groene ruimte $\quad 10$

KF Plantenteelt $\quad 26$

KF Veehouderij 16

KF Levensmiddelentechnologie $\quad 15$

KF Bloemschikken

KF Groene ruimte

$\begin{array}{ll}\text { MKF Bouw } & 21\end{array}$

MKF Houtbewerking en woninginrichting

MKF Grond-, water- en wegenbouw

MKF Reclame, presentatie en communicatie

MKF Werktuigbouwkunde $\quad 18$

MKF Motorvoertuigen $\quad 16$

MKF Energie- en informatietechniek $\quad 15$

MKF Informatietechniek

MKF Grafische techniek, communicatie, audiovisueel $\quad 23$

MKF Laboratoriumtechniek $\quad 32$

MKF Scheepvaart $\quad 17$

MKF Transport en logistiek $\quad 13$

MKF Bedrijfsadministratief 18

MKF Commercieel $\quad 19$

MKF Economisch-juridisch 33

MKF Secretarieel $\quad 21$

MKF Detailhandel/ambulante handel 26

MKF Horeca, instellingskeuken en contractcatering $\quad 41$

MKF Toerisme, recreatie en reizen 18

MKF Assistenten gezondheidszorg $\quad 15$

MKF Facilitaire dienstverlening $\quad 32$

MKF Sport en bewegen $\quad 24$ 
Tabel B3.13 (vervolg)

Percentage werkende schoolverlaters dat op zoek is naar een andere baan

BOL niveau 3/4 (vervolg)

MKF Verpleging en verzorging 16

ZB Uiterlijke verzorging $\quad 17$

MKF Sociaal-cultureel werker

MKF Sociaal-pedagogisch werk algemeen $\quad 32$

MKF Sociaal-juridisch werk

BBL niveau $1 / 2$

BB Bouw

BB Constructie(bank)werken/(isolatie)plaatwerken/pijpenbew.

BB Machinebankwerken/verspanen 6

BB Wegvervoer $\quad 11$

BB Detailhandel/ambulante handel $\quad 25$

BB Horeca, instellingskeuken en contractcatering $\quad 15$

BB Facilitaire dienstverlening $\quad 5$

BB Verpleging en verzorging 32

BBL niveau $3 / 4$

MKF Bouw

ZB Grond-, water- en wegenbouw

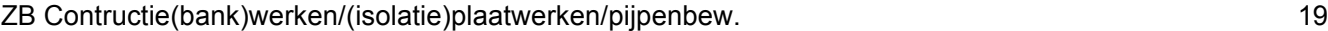

MKF Motorvoertuigen $\quad 13$

Specialist Energie- en informatietechniek 33

Specialist Installatie-, service- en onderhoudstechniek 13

MKF Procestechniek $\quad 21$

MKF Automatisering

MKF Detailhandel/ambulante handel $\quad 17$

MKF Horeca, instellingskeuken en contractcatering 16

MKF Verpleging en verzorging $\quad 22$

MKF Sociaal-pedagogisch werk 15

Zie ook toelichting bladzijde 51 
Tabel B3.14

Deelname aan een cursus of bedrijfsopleiding door werkende schoolverlaters

\section{BOL niveau $1 / 2$}

BB Bloemschikken

BB Houtbewerking en woninginrichting

BB Bedrijfsadministratie $\quad 42$

\begin{tabular}{ll} 
BB Beveiliging & 41 \\
\hline$B$ Secraileel & 429
\end{tabular}

BB Secretarieel $\quad 29$

BB Detailhandel/ambulante handel $\quad 27$

BB Horeca, instellingskeuken en contractcatering $\quad 10$

BB Verpleging en verzorging 6

BOL niveau 3/4

ZB Plantenteelt

ZB Veehouderij $\quad 25$

ZB Bloemschikken $\quad 15$

ZB Groene ruimte

KF Plantenteelt $\quad 25$

KF Veehouderij

KF Levensmiddelentechnologie $\quad 51$

KF Bloemschikken $\quad 12$

KF Groene ruimte $\quad 21$

MKF Bouw

MKF Houtbewerking en woninginrichting

MKF Grond-, water- en wegenbouw

MKF Reclame, presentatie en communicatie 19

MKF Werktuigbouwkunde $\quad 62$

MKF Motorvoertuigen

MKF Energie- en informatietechniek $\quad 65$

MKF Informatietechniek $\quad 49$

MKF Grafische techniek, communicatie, audiovisueel $\quad 22$

MKF Laboratoriumtechniek 38

MKF Scheepvaart $\quad 32$

MKF Transport en logistiek 36

MKF Bedrijfsadministratief $\quad 51$

MKF Commercieel $\quad 61$

MKF Economisch-juridisch $\quad 50$

MKF Secretarieel

MKF Detailhandel/ambulante handel 39

MKF Horeca, instellingskeuken en contractcatering $\quad 39$

MKF Toerisme, recreatie en reizen

MKF Assistenten gezondheidszorg 38

MKF Facilitaire dienstverlening $\quad 48$

MKF Sport en bewegen $\quad 53$

MKF Verpleging en verzorging $\quad 21$

ZB Uiterlijke verzorging

MKF Sociaal-cultureel werker $\quad 24$

MKF Sociaal-pedagogisch werk algemeen $\quad 25$

MKF Sociaal-juridisch werk $\quad 36$

Zie ook toelichting bladzijde 52 
Tabel B3.15

Belangrijkste cursussen of bedrijfsopleidingen waaraan werkende schoolverlaters deelnemen

BOL BB Bedrijfsadministratie

Administratief

Computer en informatica

Onderwijs

Bedrijfsadministratie, accountancy

Geld- en bankzaken

Verzekeringswezen

Sociale verzorging

Maatschappelijk werk

Persoonlijke ontplooiing

Communicatieve vaardigheden

BOL BB Beveiliging

BB, Bedrijfszelfbescherming

Recht

Administratief 16

Biologie $\quad 16$

BOL BB Secretarieel

Computer en informatica $\quad 15$

Bedrijfsadministratie, accountancy $\quad 15$

BB, bedrijfszelfbescherming $\quad 14$

\begin{tabular}{lc} 
CCommunicatie & 8 \\
\hline Administate & 14
\end{tabular}

Administratief $\quad 8$

Commercieel $\quad 8$

Verzekeringswezen $\quad 8$

\begin{tabular}{ll} 
Recht & 8 \\
\hline
\end{tabular}

Communicatieve vaardigheden $\quad 7$

$\begin{array}{ll}\text { Germaanse talen } & 7\end{array}$

BOL BB Detailhandel/ambulante handel

Bedrijfsadministratie, accountancy 26

Farmacie $\quad 18$

BB, Bedrijfszelfbescherming $\quad 17$

Geneeskunde $\quad 13$

$\begin{array}{ll}\text { Commercieel } & 10\end{array}$

Communicatieve vaardigheden $\quad 10$

$\begin{array}{ll}\text { Economie } & 7\end{array}$

BOL BB Horeca, instellingskeuken en contractcatering

$\begin{array}{ll}\text { Horeca } & 50\end{array}$

BOL BB Verpleging en verzorging

Bedrijfstechniek, technische bedrijfsvoe $\quad 26$

\begin{tabular}{ll} 
Gezondheidszorg & 25 \\
\hline
\end{tabular}

Gedrag en maatschappij $\quad 25$

$\begin{array}{ll}\text { Communicatieve vaardigheden } & 25\end{array}$ 
Tabel B3.15 (vervolg)

Belangrijkste cursussen of bedrijfsopleidingen waaraan werkende schoolverlaters deelnemen

\section{BOL ZB Plantenteelt}

Landbouw

Landbouw

Weg-, railvervoer

Landbouwmechanisatie

Bouwkunde

$\mathrm{BB}$, Bedrijfszelfbescherming

BOL ZB Veehouderij

Landbouw

Veeteelt

$\mathrm{BB}$, bedrijfszelfbescherming

Weg-, railvervoer

Uiterlijke verzorging

Secretarieel (incl. tekstverwerking, steno)

Gezondheidszorg

Politie

BOL ZB Bloemschikken

Tuinbouw

BB, Bedrijfszelfbescherming

Economie

Kunst en cultuur

Landbouw

Communicatie

Verzekeringswezen

BOL KF Plantenteelt

Tuinbouw

$\mathrm{BB}$, Bedrijfszelfbescherming

Commercieel

Computer en informatica

Communicatieve vaardigheden

Germaanse talen

BOL KF Veehouderij

Landbouw

$\mathrm{BB}$, Bedrijfszelfbescherming

Landbouw

Bedrijfsadministratie, accountancy

Verzekeringswezen

Hobbycursus

Tuinbouw

Weg-, railvervoer

Bedrijfskunde, management, efficiency

BOL KF Levensmiddelentechnologie

Techniek 
Tabel B3.15 (vervolg)

Belangrijkste cursussen of bedrijfsopleidingen waaraan werkende schoolverlaters deelnemen

BOL KF Groene ruimte

Computer en informatica

Landbouw

Bouwkunde

Bosbouw

9

Recht

BB, Bedrijfszelfbescherming

Biologie

BOL MKF Bouw

Bouwkunde

Bedrijfskunde, management, efficiency

$\mathrm{BB}$, Bedrijfszelfbescherming

Techniek

Werktuigbouwkunde

BOL MKF Houtbewerking en woninginrichting

Bedrijfskunde, management, efficiency

$\mathrm{BB}$, Bedrijfszelfbescherming

Secretarieel (incl. tekstverwerking, steno)

Commercieel

Basisonderwijs/onderwijzers

Bouwkunde

Communicatieve vaardigheden

BOL MKF Grond-, water- en wegenbouw

Bedrijfskunde, management, efficiency

$\mathrm{BB}$, Bedrijfszelfbescherming

Weg- en waterbouwkunde, landmeetkunde 11

Computer en informatica 11

Telecommunicatie/datacommunicatie 11

Economie 11

Commercieel

BOL MKF Werktuigbouwkunde

Techniek

Werktuigbouwkunde

$\mathrm{BB}$, Bedrijfszelfbescherming

Elektrotechniek

Communicatie

Metaalbewerking

Bedrijfskunde, management, efficiency

BOL MKF Motorvoertuigen

Bedrijfskunde, management, efficiency 16

Elektrotechniek 14

$\begin{array}{ll}\text { Werktuigbouwkunde } & 10\end{array}$

Commercieel 10

Cursus/bedrijfsopleiding $\quad 5$

Techniek

Procestechniek $\quad 5$

Weg-, railvervoer $\quad 5$

Marketing, reclame $\quad 5$

Sociale verzorging $\quad 5$ 
Tabel B3.15 (vervolg)

Belangrijkste cursussen of bedrijfsopleidingen waaraan werkende schoolverlaters deelnemen

BOL MKF Motorvoertuigen (vervolg)

Persoonlijke ontplooiing

Communicatieve vaardigheden

BOL MKF Energie- en informatietechniek

Techniek

Elektrotechniek

Computer en informatica

$\mathrm{BB}$, Bedrijfszelfbescherming

BOL MKF Informatietechniek

Computer en informatica

Administratief

Commercieel

Bedrijfskunde, management, efficiency

BOL MKF Grafische techniek, communicatie, audiovisueel

Computer en informatica

Marketing, reclame

Grafische techniek

Procestechniek

Bedrijfskunde, management, efficiency

Detailhandel (incl. middenstandsdiploma)

BOL MKF Laboratoriumtechniek

$\mathrm{BB}$, Bedrijfszelfbescherming

Techniek

Geneeskunde

Natuurkunde, materiaalkunde

Bedrijfskunde, management, efficiency

Uiterlijke verzorging

Scheikunde

BOL MKF Scheepvaart

Computer en informatica

Scheepvaart

$\mathrm{BB}$, Bedrijfszelfbescherming

Cursus/bedrijfsopleiding

Werktuigbouwkunde

Weg-, railvervoer

Verpleging

Communicatieve vaardigheden

Brandweer

BOL MKF Transport en logistiek

Communicatie

$\mathrm{BB}$, Bedrijfszelfbescherming

Weg-, railvervoer

Scheepvaart

Bedrijfskunde, management, efficiency

Secretarieel (incl. tekstverwerking, steno) 
Tabel B3.15 (vervolg)

Belangrijkste cursussen of bedrijfsopleidingen waaraan werkende schoolverlaters deelnemen

BOL MKF Bedrijfsadministratief

Bedrijfsadministratie, accountancy

Computer en informatica

Geld- en bankzaken

Algemene en bedrijfseconomie

Bedrijfskunde, management, efficiency

Recht

Belastingen

BOL MKF Commercieel

Verzekeringswezen

Geld- en bankzaken

Commercieel

Bedrijfskunde, management, efficiency

BOL MKF Economisch-juridisch

Verzekeringswezen

Bedrijfsadministratie, accountancy

Belastingen

Computer en informatica

Bedrijfskunde, management, efficiency

Geld- en bankzaken

Beeldende kunst

\section{BOL MKF Secretarieel}

Secretarieel (incl. tekstverwerking, steno)

Bedrijfskunde, management, efficiency 11

Commercieel

Computer en informatica

Bedrijfsadministratie, accountancy

Verzekeringswezen

Persoonlijke ontplooiing

Communicatieve vaardigheden

Gezondheidszorg

BOL MKF Detailhandel/ambulante handel

Commercieel

Marketing, reclame

Bedrijfskunde, management, efficiency

Secretarieel (incl. tekstverwerking, steno)

$\mathrm{BB}$, Bedrijfszelfbescherming

BOL MKF Horeca, instellingskeuken en contractcatering

Verzekeringswezen

Romaanse talen

Computer en informatica

Communicatie

Secretarieel (incl. tekstverwerking, steno)

Communicatieve vaardigheden

$\mathrm{BB}$, Bedrijfszelfbescherming 
Tabel B3.15 (vervolg)

Belangrijkste cursussen of bedrijfsopleidingen waaraan werkende schoolverlaters deelnemen

BOL MKF Toerisme, recreatie en reizen

Commercieel

Verzekeringswezen

Geld- en bankzaken

Bedrijfskunde, management, efficiency

Marketing, reclame

Luchtvaart

Personeelswerk

Communicatieve vaardigheden

BOL MKF Assistenten gezondheidszorg

Geneeskunde

Gezondheidszorg

Farmacie

Verpleging

BOL MKF Facilitaire dienstverlening

Communicatieve vaardigheden

Bedrijfskunde, management, efficiency

Administratief

Secretarieel (incl. tekstverwerking, steno)

Bedrijfsadministratie, accountancy

Geneeskunde

Personeelswerk

$\mathrm{BB}$, Bedrijfszelfbescherming

BOL MKF Sport en bewegen

Cursus/bedrijfsopleiding

Bedrijfskunde, management, efficiency

Fysiotherapie, bewegingsleer

Commercieel

Toerisme

Gezondheidszorg

Persoonlijke ontplooiing

Onderwijs

$\mathrm{BB}$, Bedrijfszelfbescherming

BOL MKF Verpleging en verzorging

Verpleging

Gezondheidszorg

Ziekenverzorging

$\mathrm{BB}$, Bedrijfszelfbescherming

Communicatieve vaardigheden

BOL ZB Uiterlijke verzorging

Uiterlijke verzorging

Geneeskunde

Farmacie

Grafische techniek

Secretarieel (incl. tekstverwerking, steno) 
Tabel B3.15 (vervolg)

Belangrijkste cursussen of bedrijfsopleidingen waaraan werkende schoolverlaters deelnemen

\section{BOL MKF Sociaal-cultureel werker}

Horeca

Sociaal werk

Pedagog.-didactische cursussen voor leer

Computer en informatica

Bedrijfskunde, management, efficiency

Kinderverzorging

BOL MKF Sociaal-pedagogisch werk algemeen

$\mathrm{BB}$, Bedrijfszelfbescherming

Gezondheidszorg

Verpleging

Gedrag en maatschappij

Kinderverzorging

Communicatieve vaardigheden

BOL MKF Sociaal-juridisch werk

Computer en informatica

Personeelswerk

Verzekeringswezen

Recht

Nederlands

$\mathrm{BB}$, Bedrijfszelfbescherming

Communicatie

Gezondheidszorg

Fysiotherapie, bewegingsleer

Sociale wetenschappen

Zie ook toelichting bladzijde 56 
Tabel B4. 1

Enkele kernindicatoren

\begin{tabular}{|c|c|c|c|c|c|c|c|c|c|}
\hline \multirow[t]{2}{*}{ Opleidingsrichting } & \multirow[t]{2}{*}{$\begin{array}{r}\text { op- } \\
\text { gehoogd } \\
\text { aantal } \\
\text { populatie }\end{array}$} & \multirow[t]{2}{*}{$\begin{array}{r}\text { verder } \\
\text { leren }\end{array}$} & $\begin{array}{r}\text { zelfde } \\
\text { opleiding } \\
\text { opnieuw? }\end{array}$ & $\begin{array}{r}\text { werkloos- } \\
\text { heid }\end{array}$ & $\begin{array}{r}\text { intrede } \\
\text { werkloos- } \\
\text { heid }\end{array}$ & $\begin{array}{r}\text { flexibele } \\
\text { aanstelling }\end{array}$ & $\begin{array}{r}\text { bruto } \\
\text { uurloon }\end{array}$ & $\begin{array}{r}\text { minimaal } \\
\text { eigen } \\
\text { niveau }\end{array}$ & \multirow[t]{2}{*}{$\begin{array}{r}\text { eigen/ } \\
\text { verwante } \\
\text { richting }\end{array}$} \\
\hline & & & $\%$ & $\%$ & maanden & $\%$ & $\%$ & $\%$ & \\
\hline \multicolumn{10}{|l|}{ VBO } \\
\hline IVBO Landbouw en natuurlijke omgeving & 1.407 & 81 & $x$ & 17 & 1,3 & 28 & 8,72 & 54 & 38 \\
\hline IVBO Verzorging & 1.556 & 96 & $\mathrm{x}$ & - & - & - & - & - & - \\
\hline Landbouw en natuurlijke omgeving & 3.309 & 92 & $\mathrm{x}$ & 10 & 0,4 & 18 & 8,23 & 74 & 46 \\
\hline Bouwtechniek & 4.413 & 87 & $\mathrm{x}$ & 0 & 0,4 & - & 10,77 & 69 & 70 \\
\hline Mechanische techniek & 2.460 & 88 & $\mathrm{x}$ & 3 & 0,2 & 10 & 7,93 & 72 & 55 \\
\hline Elektrotechniek & 3.660 & 89 & $\mathrm{x}$ & 7 & 1,2 & 14 & 9,12 & 63 & 57 \\
\hline Motorvoertuigentechniek & 2.179 & 92 & $\mathrm{x}$ & 0 & 0,2 & - & 7,36 & 72 & 72 \\
\hline Consumptieve techniek & 2.447 & 87 & $\mathrm{x}$ & 4 & 0,5 & 16 & 10,84 & 57 & 69 \\
\hline Administratie & 4.587 & 92 & $\mathrm{x}$ & 13 & 0,4 & 35 & 8,60 & 68 & 19 \\
\hline Verkoop & 1.974 & 87 & $\mathrm{x}$ & 0 & 0,2 & 13 & 8,47 & 63 & 29 \\
\hline Handel & 1.060 & 92 & $\mathrm{x}$ & 0 & 0,6 & 3 & - & - & - \\
\hline Verzorging & 8.488 & 96 & $\mathrm{x}$ & - & - & - & 8,85 & 85 & 52 \\
\hline Uiterlijke verzorging & 621 & 90 & $\mathrm{x}$ & - & - & - & - & - & - \\
\hline Mode en kleding & 659 & - & $x$ & - & - & - & - & - & - \\
\hline \multicolumn{10}{|l|}{ BOL niveau $1 / 2$} \\
\hline BB Bloemschikken & 95 & - & 57 & 6 & 1,2 & 33 & 11,13 & 33 & 54 \\
\hline BB Groene ruimte & 87 & - & 65 & - & - & - & - & - & - \\
\hline BB Houtbewerking en woninginrichting & 100 & - & 73 & - & - & - & - & - & 66 \\
\hline BB Motorvoertuigen & 460 & - & 51 & - & - & - & - & - & - \\
\hline BB Energie- en informatietechniek & 314 & - & 75 & - & - & - & - & - & - \\
\hline BB Bedrijfsadministratie & 1.238 & 45 & 53 & 4 & 1,2 & 24 & 13,76 & 77 & 60 \\
\hline BB Beveiliging & 210 & - & 69 & 0 & 0,6 & - & - & 16 & 31 \\
\hline BB Secretarieel & 1.330 & 40 & 50 & 12 & 1,9 & 41 & 15,94 & 60 & 47 \\
\hline
\end{tabular}


Tabel B4. 1 (vervolg)

Enkele kernindicatoren

\begin{tabular}{|c|c|c|c|c|c|c|c|c|c|}
\hline \multirow[t]{2}{*}{ Opleidingsrichting } & \multirow[t]{2}{*}{$\begin{array}{r}\text { op- } \\
\text { gehoogd } \\
\text { aantal } \\
\text { populatie }\end{array}$} & \multirow{2}{*}{$\begin{array}{r}\text { verder } \\
\text { leren } \\
\\
\\
\\
\% \\
\end{array}$} & \multirow{2}{*}{$\begin{array}{r}\text { zelfde } \\
\text { opleiding } \\
\text { opnieuw? } \\
\%\end{array}$} & \multirow{2}{*}{$\begin{array}{r}\text { werkloos- } \\
\text { heid } \\
\%\end{array}$} & \multirow{2}{*}{$\begin{array}{r}\text { intrede } \\
\text { werkloos- } \\
\text { heid } \\
\text { maanden }\end{array}$} & \multirow{2}{*}{$\begin{array}{r}\text { flexibele } \\
\text { aanstelling } \\
\%\end{array}$} & \multirow{2}{*}{$\begin{array}{r}\text { bruto } \\
\text { uurloon } \\
\\
\\
\% \\
\end{array}$} & \multirow{2}{*}{$\begin{array}{r}\text { minimaal } \\
\text { eigen } \\
\text { niveau } \\
\%\end{array}$} & \multirow{2}{*}{$\begin{array}{r}\text { eigen } \\
\text { verwante } \\
\text { richting } \\
\%\end{array}$} \\
\hline & & & & & & & & & \\
\hline \multicolumn{10}{|l|}{ BOL niveau $1 / 2$ (vervolg) } \\
\hline AB Detailhandel/ambulante handel & 518 & - & 32 & - & - & - & - & - & - \\
\hline BB Detailhandel/ambulante handel & 1.984 & 43 & 54 & 5 & 1,0 & 11 & 12,53 & 38 & 42 \\
\hline BB Horeca, instellingskeuken en contractcatering & 1.551 & - & 65 & 0 & 0,2 & 17 & 12,07 & 60 & 60 \\
\hline BB Verpleging en verzorging & 1.355 & 71 & 55 & 4 & 0,4 & 22 & 14,63 & 47 & 66 \\
\hline \multicolumn{10}{|l|}{ BOL niveau $3 / 4$} \\
\hline ZB Plantenteelt & 220 & - & 63 & 3 & 0,0 & 14 & 15,56 & 56 & 68 \\
\hline ZB Veehouderij & 400 & - & 73 & 3 & 0,6 & 22 & 13,99 & 66 & 52 \\
\hline ZB Bloemschikken & 339 & 27 & 68 & 6 & 0,3 & 23 & 12,02 & 64 & 72 \\
\hline ZB Groene ruimte & 171 & - & 58 & 0 & 0,4 & 6 & 17,77 & 82 & 73 \\
\hline KF Plantenteelt & 318 & 59 & 70 & 2 & 0,2 & 21 & 18,74 & 72 & 69 \\
\hline KF Veehouderij & 602 & 36 & 76 & 2 & 0,2 & 20 & 16,28 & 53 & 49 \\
\hline KF Levensmiddelentechnologie & 214 & - & 81 & 0 & 0,0 & - & - & 75 & 60 \\
\hline KF Bloemschikken & 179 & 32 & 73 & 4 & 0,5 & 11 & 15,52 & 74 & 81 \\
\hline KF Dierverzorging en veterinaire ondersteuning & 103 & - & 91 & - & - & - & - & - & - \\
\hline KF Groene ruimte & 443 & 52 & 75 & 0 & 0,6 & 14 & 17,54 & 74 & 80 \\
\hline KF Milieutoezicht & 127 & 54 & 61 & - & - & - & - & - & - \\
\hline MKF Bouw & 1.557 & 58 & 77 & 3 & 0,2 & 12 & 18,91 & 82 & 79 \\
\hline MKF Houtbewerking en woninginrichting & 234 & 29 & 90 & 0 & 0,5 & 17 & 19,01 & 72 & 68 \\
\hline MKF Grond-, water- en wegenbouw & 535 & 44 & 84 & 0 & 0,2 & 5 & 20,47 & 91 & 86 \\
\hline MKF Beschermings- en afwerkingstechnieken & 37 & - & 76 & - & - & - & - & - & - \\
\hline MKF Reclame, presentatie en communicatie & 106 & 42 & 77 & 3 & 0,8 & 12 & 18,37 & 81 & 59 \\
\hline MKF Fijnmechanische techniek & 94 & - & 67 & - & - & - & - & - & - \\
\hline MKF Operationele techniek & 41 & - & 70 & - & - & - & - & - & - \\
\hline
\end{tabular}


Tabel B4. 1 (vervolg)

Enkele kernindicatoren

\begin{tabular}{|c|c|c|c|c|c|c|c|c|c|}
\hline \multirow[t]{2}{*}{ Opleidingsrichting } & \multirow[t]{2}{*}{$\begin{array}{r}\text { op- } \\
\text { gehoogd } \\
\text { aantal } \\
\text { populatie }\end{array}$} & \multirow[t]{2}{*}{$\begin{array}{r}\text { verder } \\
\text { leren }\end{array}$} & $\begin{array}{r}\text { zelfde } \\
\text { opleiding } \\
\text { opnieuw? }\end{array}$ & $\begin{array}{r}\text { werkloos- } \\
\text { heid }\end{array}$ & \multicolumn{2}{|c|}{$\begin{array}{l}\text { intrede flexibele } \\
\text { werkloos- aanstelling } \\
\text { heid }\end{array}$} & $\begin{array}{r}\text { bruto } \\
\text { uurloon }\end{array}$ & $\begin{array}{r}\text { minimaal } \\
\text { eigen } \\
\text { niveau }\end{array}$ & \multirow{2}{*}{$\begin{array}{r}\text { eigen } \\
\text { verwante } \\
\text { richting } \\
\% \\
\end{array}$} \\
\hline & & & $\%$ & $\%$ & maanden & $\%$ & $\%$ & $\%$ & \\
\hline \multicolumn{10}{|l|}{ BOL niveau 3/4 (vervolg) } \\
\hline MKF Werktuigbouwkunde & 1.722 & 52 & 74 & 0 & 0,1 & 12 & 19,07 & 82 & 81 \\
\hline MKF Motorvoertuigen & 185 & 46 & 66 & 0 & 0,2 & 14 & 17,50 & 69 & 82 \\
\hline MKF Energie- en informatietechniek & 2.616 & 45 & 72 & 1 & 0,2 & 10 & 19,51 & 81 & 83 \\
\hline MKF Informatietechniek & 254 & 55 & 85 & 0 & 0,0 & & 18,89 & 93 & 77 \\
\hline MKF Scheepsbouwkundige (scheepsbouw) & 98 & - & 56 & - & - & - & - & - & - \\
\hline MKF Grafische techniek, communicatie, audiovisueel & 676 & 32 & 78 & 1 & 0,4 & 8 & 19,38 & 85 & 85 \\
\hline MKF Laboratoriumtechniek & 1.148 & 51 & 70 & 7 & 0,7 & 35 & 20,43 & 93 & 91 \\
\hline MKF Procestechniek & 159 & - & 86 & - & - & - & - & - & - \\
\hline MKF Scheepvaart & 234 & 35 & 78 & 2 & 0,6 & 11 & 20,37 & 75 & 87 \\
\hline MKF Transport en logistiek & 143 & - & 66 & 17 & 0,0 & 4 & 18,51 & 80 & 42 \\
\hline MKF Automatisering & 25 & - & 59 & - & - & - & - & - & - \\
\hline MKF Bedrijfsadministratief & 3.115 & 67 & 76 & 2 & 0,2 & 16 & 16,15 & 86 & 74 \\
\hline MKF Commercieel & 1.720 & 51 & 65 & 1 & 0,1 & 15 & 16,40 & 82 & 61 \\
\hline MKF Economisch-juridisch & 685 & 66 & 64 & 3 & 0,8 & 13 & 15,36 & 82 & 63 \\
\hline MKF Secretarieel & 1.852 & 34 & 69 & 2 & 0,2 & 18 & 16,27 & 86 & 74 \\
\hline MKF Detailhandel/ambulante handel & 3.212 & 57 & 60 & 3 & 0,2 & 14 & 15,89 & 63 & 49 \\
\hline MKF Horeca, instellingskeuken en contractcatering & 1.116 & 38 & 61 & 0 & 0,2 & 22 & 19,78 & 80 & 69 \\
\hline MKF Toerisme, recreatie en reizen & 1.309 & 37 & 68 & 1 & 0,3 & 15 & 17,38 & 88 & 81 \\
\hline MKF Assistenten gezondheidszorg & 1.269 & 27 & 78 & 0 & 0,3 & 5 & 16,36 & 85 & 91 \\
\hline MKF Facilitaire dienstverlening & 714 & 47 & 42 & 0 & 1,0 & 33 & 16,17 & 63 & 44 \\
\hline MKF Sport en bewegen & 371 & 57 & 88 & 1 & 0,6 & 16 & 21,78 & 78 & 70 \\
\hline MKF Verpleging en verzorging & 3.443 & 56 & 62 & 2 & 0,2 & 13 & 17,63 & 79 & 91 \\
\hline ZB Uiterlijke verzorging & 314 & - & 60 & 0 & 0,6 & 19 & 12,87 & 60 & 66 \\
\hline
\end{tabular}


Tabel B4. 1 (vervolg)

Enkele kernindicatoren

\begin{tabular}{|c|c|c|c|c|c|c|c|c|c|}
\hline \multirow[t]{2}{*}{ Opleidingsrichting } & \multirow[t]{2}{*}{$\begin{array}{r}\text { op- } \\
\text { gehoogd } \\
\text { aantal } \\
\text { populatie }\end{array}$} & \multirow[t]{2}{*}{$\begin{array}{r}\text { verder } \\
\text { leren }\end{array}$} & $\begin{array}{r}\text { zelfde } \\
\text { opleiding } \\
\text { opnieuw? }\end{array}$ & $\begin{array}{r}\text { werkloos- } \\
\text { heid }\end{array}$ & $\begin{array}{r}\text { intrede } \\
\text { werkloos- } \\
\text { heid }\end{array}$ & $\begin{array}{r}\text { flexibele } \\
\text { aanstelling }\end{array}$ & $\begin{array}{r}\text { bruto } \\
\text { uurloon }\end{array}$ & $\begin{array}{r}\text { minimaal } \\
\text { eigen } \\
\text { niveau }\end{array}$ & \multirow{2}{*}{$\begin{array}{r}\text { eigen/ } \\
\text { verwante } \\
\text { richting } \\
\% \\
\end{array}$} \\
\hline & & & $\%$ & $\%$ & maanden & $\%$ & $\%$ & $\%$ & \\
\hline \multicolumn{10}{|l|}{ BOL niveau $3 / 4$ (vervolg) } \\
\hline MKF Sociaal-cultureel werker & 277 & 51 & 64 & 4 & 0,5 & 36 & 18,07 & 74 & 69 \\
\hline MKF Sociaal-pedagogisch werk algemeen & 6.434 & 52 & 73 & 3 & 0,4 & 21 & 18,37 & 79 & 78 \\
\hline MKF Sociaal-juridisch werk & 869 & 64 & 73 & 4 & 0,5 & 25 & 20,92 & 83 & 56 \\
\hline \multicolumn{10}{|l|}{ BBL niveau $1 / 2$} \\
\hline BB Bouw & 1.830 & 53 & 76 & 0 & 0,1 & - & 23,80 & 41 & 70 \\
\hline BB Beschermings- en afwerkingstechnieken & 508 & - & 87 & - & - & - & - & - & - \\
\hline BB Constructie(bank)werken/(isolatie)plaatwerken/pijpenbew. & 498 & - & 67 & 4 & 0,1 & 6 & 15,64 & 45 & 57 \\
\hline BB Machinebankwerken/verspanen & 308 & - & 83 & 0 & 0,0 & 7 & 13,59 & 43 & 88 \\
\hline BB Energie- en informatietechniek & 133 & - & 55 & - & - & - & - & - & - \\
\hline BB Wegvervoer & 705 & - & 79 & 0 & 0,0 & 10 & 16,65 & 30 & 61 \\
\hline BB Secretarieel & 170 & - & 49 & - & - & - & - & - & - \\
\hline BB Detailhandel/ambulante handel & 1.282 & - & 64 & 3 & 0,5 & - & 11,75 & 13 & 19 \\
\hline BB Horeca, instellingskeuken en contractcatering & 1.757 & 79 & 48 & 0 & 0,1 & 13 & 15,42 & 52 & 57 \\
\hline BB Facilitaire dienstverlening & 235 & - & 60 & 0 & 0,5 & - & 19,12 & 63 & 73 \\
\hline BB Verpleging en verzorging & 462 & 30 & 66 & 4 & 1,0 & 21 & 20,87 & 57 & 70 \\
\hline \multicolumn{10}{|l|}{ BBL niveau $3 / 4$} \\
\hline MKF Bouw & 995 & - & 87 & 0 & 0,0 & - & 24,00 & 28 & 75 \\
\hline ZB Grond-, water- en wegenbouw & 587 & - & 70 & 0 & 0,0 & 5 & - & 20 & 71 \\
\hline ZB Contructie(bank)werken/(isolatie)plaatwerken/pijpenbew. & 108 & - & 56 & 7 & 0,2 & - & - & 25 & 51 \\
\hline MKF Motorvoertuigen & 502 & - & 95 & 0 & 0,0 & 5 & 20,73 & 48 & 63 \\
\hline Specialist Energie- en informatietechniek & 118 & - & 86 & 0 & 0,1 & - & - & 54 & 81 \\
\hline
\end{tabular}


Tabel B4. 1 (vervolg)

Enkele kernindicatoren

\begin{tabular}{|c|c|c|c|c|c|c|c|c|c|}
\hline \multirow[t]{2}{*}{ Opleidingsrichting } & \multirow[t]{2}{*}{$\begin{array}{r}\text { op- } \\
\text { gehoogd } \\
\text { aantal } \\
\text { populatie }\end{array}$} & \multirow[t]{2}{*}{$\begin{array}{r}\text { verder } \\
\text { leren }\end{array}$} & $\begin{array}{r}\text { zelfde } \\
\text { opleiding } \\
\text { opnieuw? }\end{array}$ & $\begin{array}{r}\text { werkloos- } \\
\text { heid }\end{array}$ & $\begin{array}{r}\text { intrede } \\
\text { werkloos- } \\
\text { heid }\end{array}$ & \multirow{2}{*}{$\begin{array}{r}\text { flexibele } \\
\text { aanstelling } \\
\% \\
\%\end{array}$} & \multirow{2}{*}{$\begin{array}{r}\text { bruto } \\
\text { uurloon } \\
\\
\% \\
\end{array}$} & \multirow{2}{*}{$\begin{array}{r}\text { minimaal } \\
\text { eigen } \\
\text { niveau } \\
\% \\
\end{array}$} & \multirow{2}{*}{$\begin{array}{r}\text { eigen/ } \\
\text { verwante } \\
\text { richting } \\
\% \\
\end{array}$} \\
\hline & & & $\%$ & $\%$ & maanden & & & & \\
\hline \multicolumn{10}{|l|}{ BBL niveau $3 / 4$ (vervolg) } \\
\hline Specialist Installatie-, service- en onderhoudstechniek & 901 & - & 90 & 0 & 0,0 & 4 & 19,95 & 42 & 89 \\
\hline MKF Procestechniek & 301 & - & 85 & 0 & 0,5 & 5 & 29,66 & 68 & 60 \\
\hline MKF Automatisering & 223 & - & 60 & - & - & - & - & 93 & 55 \\
\hline MKF Detailhandel/ambulante handel & 1.144 & - & 52 & 0 & 0,1 & 11 & 14,60 & 32 & 46 \\
\hline MKF Horeca, instellingskeuken en contractcatering & 961 & - & 66 & 0 & 0,3 & 11 & 19,32 & 60 & 77 \\
\hline MKF Verpleging en verzorging & 4.862 & - & 64 & - & - & 4 & 23,90 & 82 & 88 \\
\hline ZB Uiterlijke verzorging & 720 & - & 71 & - & - & - & - & - & 75 \\
\hline MKF Sociaal-pedagogisch werk & 1.079 & - & 71 & 0 & 0,6 & 18 & 18,70 & 65 & 75 \\
\hline
\end{tabular}

$\mathrm{x}=$ vraag niet opgenomen

- = te weinig waarnemingen

Zie ook toelichting bladzijde 59 en de tabellen C5, B2.1, B1.4, B3.1, B3.3, B3.8, B3.9 en B3.10 
C. Respons 



\section{Inhoud}

C1 Ongewogen aantal respondenten verbijzonderd naar bestemming per opleidingssector

C2 Naar landelijke populatie gewogen aantal schoolverlaters verbijzonderd naar bestemming per opleidingssector

C3 Responspercentage per opleidingssector

C4 Ongewogen aantal respondenten verbijzonderd naar bestemming per opleidingsrichting

C5 Naar landelijke populatie gewogen aantal schoolverlaters verbijzonderd naar bestemming per opleidingsrichting

C6 Responspercentage per opleidingsrichting 
Tabel C1

Ongewogen aantal respondenten verbijzonderd naar bestemming per opleidingssector

\begin{tabular}{|c|c|c|c|c|c|c|c|}
\hline Opleidingssector & studie & BBL & $\begin{array}{r}\text { betaald } \\
\text { werk }\end{array}$ & $\begin{array}{c}\text { werk- } \\
\text { loos }\end{array}$ & anders & $\begin{array}{l}\text { onbe- } \\
\text { kend }\end{array}$ & totaal \\
\hline AVO totaal & 3.039 & 113 & 320 & 10 & 67 & 22 & 3.571 \\
\hline MAVO & 819 & 82 & 119 & 2 & 29 & 10 & 1.061 \\
\hline HAVO & 1.225 & 29 & 149 & 5 & 27 & 10 & 1.445 \\
\hline VWO & 995 & 2 & 52 & 3 & 11 & 2 & 1.065 \\
\hline VBO totaal & 758 & 228 & 326 & 17 & 37 & 10 & 1.376 \\
\hline IVBO & 90 & 43 & 60 & 5 & 8 & 1 & 207 \\
\hline Landbouw & 274 & 63 & 71 & 3 & 8 & 3 & 422 \\
\hline Techniek & 109 & 67 & 101 & 3 & 11 & 4 & 295 \\
\hline Economie & 117 & 17 & 42 & 5 & 7 & 1 & 189 \\
\hline Gezondheidszorg & 168 & 38 & 52 & 1 & 3 & 1 & 263 \\
\hline BOL niveau $1 / 2$ totaal & 150 & 71 & 417 & 15 & 15 & 12 & 680 \\
\hline Landbouw & 12 & 8 & 48 & 5 & 0 & 2 & 75 \\
\hline Techniek & 24 & 18 & 90 & 0 & 3 & 4 & 139 \\
\hline Economie & 75 & 17 & 221 & 8 & 8 & 4 & 333 \\
\hline Gezondheidszorg & 39 & 28 & 58 & 2 & 4 & 2 & 133 \\
\hline BOL niveau $3 / 4$ totaal & 2.056 & 184 & 3.609 & 55 & 120 & 32 & 6.056 \\
\hline Landbouw & 194 & 15 & 558 & 7 & 16 & 10 & 800 \\
\hline Techniek & 478 & 13 & 775 & 12 & 19 & 7 & 1.304 \\
\hline Economie & 578 & 22 & 820 & 11 & 23 & 5 & 1.459 \\
\hline Gezondheidszorg & 321 & 99 & 750 & 11 & 33 & 6 & 1.220 \\
\hline Gedrag en maatschappij & 485 & 35 & 706 & 14 & 29 & 4 & 1.273 \\
\hline BBL niveau $1 / 2$ totaal & 9 & 75 & 455 & 5 & 19 & 9 & 572 \\
\hline Techniek & 3 & 51 & 290 & 1 & 7 & 3 & 355 \\
\hline Economie & 3 & 19 & 69 & 3 & 7 & 1 & 102 \\
\hline Gezondheidszorg & 3 & 5 & 96 & 1 & 5 & 5 & 115 \\
\hline BBL niveau $3 / 4$ totaal & 16 & 15 & 524 & 6 & 15 & 5 & 581 \\
\hline Techniek & 5 & 6 & 255 & 0 & 4 & 2 & 272 \\
\hline Economie & 7 & 5 & 116 & 5 & 3 & 1 & 137 \\
\hline Gezondheidszorg & 3 & 2 & 93 & 1 & 4 & 2 & 105 \\
\hline Gedrag en maatschappij & 1 & 2 & 60 & 0 & 4 & 0 & 67 \\
\hline HBO totaal & 1.748 & $\mathbf{x}$ & 10.753 & 243 & 223 & 605 & 13.572 \\
\hline Landbouw & 92 & $\mathrm{x}$ & 616 & 13 & 7 & 18 & 746 \\
\hline Onderwijs & 131 & $\mathrm{x}$ & 1.402 & 26 & 15 & 21 & 1.595 \\
\hline Techniek & 384 & $\mathrm{x}$ & 1.987 & 43 & 20 & 34 & 2.468 \\
\hline Economie & 626 & $\mathrm{x}$ & 3.145 & 73 & 56 & 61 & 3.961 \\
\hline Gezondheidszorg & 171 & $\mathrm{x}$ & 1.371 & 28 & 23 & 35 & 1.628 \\
\hline Gedrag en maatschappij & 265 & $\mathrm{x}$ & 1.700 & 45 & 41 & 38 & 2.089 \\
\hline Kunst en cultuur & 79 & $\mathrm{x}$ & 532 & 15 & 61 & 398 & 1.085 \\
\hline
\end{tabular}


Tabel C1 (vervolg)

Ongewogen aantal respondenten verbijzonderd naar bestemming per opleidingssector

\begin{tabular}{|c|c|c|c|c|c|c|c|}
\hline Opleidingssector & studie & BBL & $\begin{array}{r}\text { betaald } \\
\text { werk }\end{array}$ & $\begin{array}{r}\text { werk- } \\
\text { loos }\end{array}$ & anders & $\begin{array}{l}\text { onbe- } \\
\text { kend }\end{array}$ & totaal \\
\hline WO totaal & 342 & $\mathbf{x}$ & 7.622 & 184 & 228 & 345 & 8.721 \\
\hline Landbouw & 10 & $\mathrm{x}$ & 246 & 13 & 7 & 0 & 276 \\
\hline Techniek & 38 & $\mathrm{x}$ & 1.184 & 10 & 13 & 35 & 1.280 \\
\hline Economie & 25 & $\mathrm{x}$ & 1.259 & 24 & 16 & 46 & 1.370 \\
\hline Gezondheidszorg & 85 & $x$ & 910 & 15 & 48 & 45 & 1.103 \\
\hline Gedrag en maatschappij & 49 & $x$ & 1.605 & 50 & 62 & 34 & 1.800 \\
\hline Taal en cultuur & 70 & $x$ & 964 & 43 & 61 & 35 & 1.173 \\
\hline Recht en openbare orde & 19 & $x$ & 853 & 17 & 7 & 126 & 1.022 \\
\hline Natuurwetenschappen & 46 & $\mathrm{x}$ & 601 & 12 & 14 & 24 & 697 \\
\hline Totaal & 8.118 & 686 & 24.026 & 535 & 724 & 1040 & 35.129 \\
\hline
\end{tabular}

$\mathrm{x}=$ antwoordcategorie niet opgenomen

Toelichting

De aantallen in deze tabel betreffen het feitelijke aantal respondenten van wie de gegevens in de analyses zijn opgenomen. 
Tabel C2

Naar landelijke populatie gewogen aantal schoolverlaters verbijzonderd naar bestemming per opleidingssector

\begin{tabular}{|c|c|c|c|c|c|c|c|}
\hline Opleidingssector & studie & BBL & $\begin{array}{r}\text { betaald } \\
\text { werk }\end{array}$ & $\begin{array}{r}\text { werk- } \\
\text { loos }\end{array}$ & anders & $\begin{array}{l}\text { onbe- } \\
\text { kend }\end{array}$ & totaal \\
\hline AVO totaal & 82.156 & 3.878 & 8.749 & 229 & 2.058 & 445 & 97.514 \\
\hline MAVO & 32.186 & 3.228 & 4.557 & 71 & 1.110 & 222 & 41.373 \\
\hline HAVO & 26.877 & 612 & 3.125 & 101 & 714 & 195 & 31.623 \\
\hline VWO & 23.094 & 38 & 1.067 & 57 & 234 & 28 & 24.519 \\
\hline VBO totaal & 20.883 & 7.295 & 11.046 & 417 & 1.363 & 239 & 41.244 \\
\hline IVBO & 1.861 & 1.035 & 1.356 & 42 & 410 & 11 & 4.716 \\
\hline Landbouw & 2.152 & 503 & 554 & 23 & 66 & 10 & 3.309 \\
\hline Techniek & 5.624 & 3.611 & 5.731 & 155 & 541 & 143 & 15.805 \\
\hline Economie & 4.858 & 700 & 1.605 & 175 & 257 & 30 & 7.625 \\
\hline Gezondheidszorg & 6.388 & 1.446 & 1.799 & 21 & 88 & 46 & 9.789 \\
\hline BOL niveau $1 / 2$ totaal & 2.305 & 1.139 & 7.296 & 221 & 215 & 116 & 11.291 \\
\hline Landbouw & 33 & 24 & 230 & 15 & 0 & 6 & 308 \\
\hline Techniek & 323 & 326 & 1.301 & 0 & 23 & 43 & 2.016 \\
\hline Economie & 1.519 & 446 & 4.745 & 171 & 153 & 48 & 7.082 \\
\hline Gezondheidszorg & 429 & 343 & 1.020 & 34 & 39 & 19 & 1.885 \\
\hline BOL niveau $3 / 4$ totaal & 14.436 & 1.085 & 23.334 & 324 & 802 & 186 & 40.168 \\
\hline Landbouw & 827 & 58 & 2.344 & 31 & 53 & 34 & 3.347 \\
\hline Techniek & 3.905 & 87 & 5.708 & 71 & 156 & 50 & 9.977 \\
\hline Economie & 5.211 & 219 & 7.264 & 97 & 229 & 65 & 13.085 \\
\hline Gezondheidszorg & 1.571 & 515 & 3.832 & 48 & 186 & 26 & 6.179 \\
\hline Gedrag en maatschappij & 2.922 & 205 & 4.185 & 77 & 179 & 11 & 7.580 \\
\hline BBL niveau $1 / 2$ totaal & 239 & 2.130 & 9.389 & 44 & 260 & 210 & 12.272 \\
\hline Techniek & 82 & 1185 & 6.050 & 8 & 110 & 79 & 7.514 \\
\hline Economie & 118 & 926 & 2.419 & 19 & 126 & 57 & 3.663 \\
\hline Gezondheidszorg & 39 & 19 & 920 & 17 & 24 & 75 & 1.094 \\
\hline BBL niveau $3 / 4$ totaal & 385 & 339 & 12.714 & 101 & 349 & 137 & 14.025 \\
\hline Techniek & 151 & 90 & 4.405 & 0 & 54 & 21 & 4.722 \\
\hline Economie & 99 & 93 & 2.294 & 44 & 56 & 21 & 2.607 \\
\hline Gezondheidszorg & 114 & 114 & 4.993 & 57 & 209 & 95 & 5.583 \\
\hline Gedrag en maatschappij & 21 & 42 & 1.022 & 0 & 29 & 0 & 1.113 \\
\hline HBO totaal & 5.585 & $\mathbf{x}$ & 33.786 & 784 & 610 & 1.500 & 42.264 \\
\hline Landbouw & 214 & $\mathrm{x}$ & 1.396 & 28 & 14 & 41 & 1.693 \\
\hline Onderwijs & 592 & $x$ & 5.907 & 128 & 69 & 86 & 6.783 \\
\hline Techniek & 1.497 & $x$ & 7.381 & 155 & 68 & 108 & 9.208 \\
\hline Economie & 1.970 & $x$ & 10.029 & 245 & 162 & 201 & 12.607 \\
\hline Gezondheidszorg & 404 & $x$ & 3.336 & 78 & 53 & 83 & 3.953 \\
\hline Gedrag en maatschappij & 722 & $x$ & 4.557 & 119 & 107 & 98 & 5.604 \\
\hline Kunst en cultuur & 186 & $x$ & 1.179 & 30 & 137 & 883 & 2.416 \\
\hline
\end{tabular}


Tabel C2 (vervolg)

Naar landelijke populatie gewogen aantal schoolverlaters verbijzonderd naar bestemming per opleidingssector

\begin{tabular}{|c|c|c|c|c|c|c|c|}
\hline Opleidingssector & studie & $\mathrm{BBL}$ & $\begin{array}{r}\text { betaald } \\
\text { werk }\end{array}$ & $\begin{array}{r}\text { werk- } \\
\text { loos }\end{array}$ & anders & $\begin{array}{l}\text { onbe- } \\
\text { kend }\end{array}$ & totaal \\
\hline WO totaal & 773 & $\mathbf{x}$ & 17.227 & 416 & 515 & 780 & 19.711 \\
\hline Landbouw & 23 & $x$ & 556 & 29 & 16 & 0 & 624 \\
\hline Techniek & 86 & $\mathrm{x}$ & 2.676 & 23 & 29 & 79 & 2.893 \\
\hline Economie & 57 & $x$ & 2.846 & 54 & 36 & 104 & 3.096 \\
\hline Gezondheidszorg & 192 & $x$ & 2.057 & 34 & 108 & 102 & 2.493 \\
\hline Gedrag en maatschappij & 111 & $\mathrm{x}$ & 3.628 & 113 & 140 & 77 & 4.068 \\
\hline Taal en cultuur & 158 & $x$ & 2.179 & 97 & 138 & 79 & 2.651 \\
\hline Recht en openbare orde & 43 & $\mathrm{x}$ & 1.928 & 38 & 16 & 285 & 2.310 \\
\hline Natuurwetenschappen & 104 & $x$ & 1.358 & 27 & 32 & 54 & 1.575 \\
\hline Totaal & 126.762 & 15.866 & 123.542 & 2.535 & 6.172 & 3.613 & 278.489 \\
\hline
\end{tabular}

$\mathrm{x}=$ antwoordcategorie niet opgenomen

\section{Toelichting}

De aantallen in deze tabel zijn zodanig opgehoogd dat een representatief beeld wordt gegeven van de totale populatie van schoolverlaters. 
Tabel C3

Responspercentage per opleidingssector

AVo totaal

MAVO

AVO

VWO

VBO totaal

IVBO

Landbouw

Techniek

Economie

Gezondheidszorg

BOL niveau 1/2 totaal

Landbouw

Techniek

Economie

Gezondheidszorg

BOL niveau 3/4 totaal

Landbouw

Techniek

Economie

Gezondheidszorg

Gedrag en maatschappij

BBL niveau 1/2 totaal

Techniek

Economie

Gezondheidszorg

BBL niveau 3/4 totaal

Techniek

Economie

Gezondheidszorg

Gedrag en maatschappij

HBO totaal

Landbouw

Onderwijs

Techniek

Economie

Gezondheidszorg

Gedrag en maatschappij

Kunst en cultuur 
Tabel C3 (vervolg)

Responspercentage per opleidingssector

WO totaal

Landbouw

$\begin{array}{ll}\text { Techniek } & 49\end{array}$

Economie $\quad 46$

Gezondheidszorg $\quad 52$

Gedrag en maatschappij $\quad 55$

Taal en cultuur $\quad 51$

Recht en openbare orde $\quad 42$

Natuurwetenschappen $\quad 55$

$\begin{array}{ll}\text { Totaal } & 43\end{array}$

\section{Toelichting}

De responspercentages geven een beeld van het aandeel van de uitgezette vragenlijsten dat bruikbaar retour is gekomen. De responspercentages van het WO hebben betrekking op 12 universiteiten. 
Tabel C4

Ongewogen aantal respondenten verbijzonderd naar bestemming per opleidingsrichting

Opleidingsrichting

$\mathrm{BB}$

betaald

werkloos

anders

onbekend

totaal

IVBO Landbouw en natuurlijke omgeving

IVBO Verzorging

Landbouw en natuurlijke omgeving

Bouwtechniek

Mechanische techniek

Elektrotechniek

Motorvoertuigentechniek

Consumptieve techniek

Administratie

Verkoop

Handel

Verzorging

Uiterlijke verzorging

Mode en kleding

BOL niveau $1 / 2$

BB Bloemschikken

BB Groene ruimte

BB Houtbewerking en woninginrichting

BB Motorvoertuigen

BB Energie- en informatietechniek

BB Bedriifsadministratie

BB Beveiliging

BB Secretarieel

$A B$ Detailhandel/ambulante handel

BB Detailhandel/ambulante handel

BB Horeca, instellingskeuken en contractcatering

BB Verpleging en verzorging

62
15
274
29
18
31
6
9
66
28
19
129
14
11

26
3
63
21
20
8
6
10
8
6
3
30
5
1

37
3
71
30
13
20
13
17
21
19
2
31
10
8

5
0
3
0
1
1
0
1
4
1
0
0
1
0

3
5
8
1
7
1
0
2
2
2
3
2
0
0

$\begin{array}{rll}3 & 3 & 18 \\ 7 & 0 & 15 \\ 2 & 0 & 17 \\ 4 & 3 & 13 \\ 4 & 3 & 10 \\ 24 & 2 & 46 \\ 4 & 1 & 18 \\ 19 & 1 & 50 \\ 5 & 0 & 14 \\ 15 & 8 & 68 \\ 7 & 5 & 21 \\ 34 & 26 & 40\end{array}$

3
0
0
0
0
1
0
5
0
2
0
1


Tabel C4 (vervolg)

Ongewogen aantal respondenten verbijzonderd naar bestemming per opleidingsrichting

\begin{tabular}{llrl} 
Opleidingsrichting & studie & BBL & $\begin{array}{r}\text { betald } \\
\text { werk }\end{array}$ werkloos anders onbekend \\
\hline
\end{tabular}

BOL niveau $3 / 4$

ZB Plantenteelt

ZB Veehouderij

ZB Bloemschikken

ZB Groene ruimte

KF Plantenteelt

KF Veehouderij

KF Levensmiddelentechnologie

KF Bloemschikken

KF Dierverzorging en veterinaire ondersteuning

KF Groene ruimte

KF Milieutoezicht

MKF Bouw

MKF Houtbewerking en woninginrichting

MKF Grond-, water- en wegenbouw

MKF Beschermings- en afwerkingstechnieken

MKF Reclame, presentatie en communicatie

MKF Fijnmechanische techniek

MKF Operationele techniek

MKF Werktuigbouwkunde

MKF Motorvoertuigen

MKF Energie- en informatietechniek

MKF Informatietechniek

MKF Scheepsbouwkundige (scheepsbouw)

MKF Grafische techniek, communicatie, audiovisuee

MKF Laboratoriumtechniek

MKF Procestechniek

$\begin{array}{rrr}4 & 1 & 45 \\ 8 & 0 & 70 \\ 6 & 4 & 93 \\ 4 & 1 & 32 \\ 35 & 0 & 49 \\ 47 & 2 & 102 \\ 13 & 0 & 18 \\ 13 & 4 & 43 \\ 7 & 0 & 15 \\ 41 & 2 & 50 \\ 13 & 0 & 9 \\ 79 & 0 & 77 \\ 20 & 2 & 67 \\ 19 & 0 & 23 \\ 4 & 0 & 15 \\ 20 & 0 & 37 \\ 12 & 0 & 7 \\ 7 & 0 & 12 \\ 77 & 4 & 91 \\ 16 & 1 & 44 \\ 82 & 2 & 122 \\ 19 & 0 & 20 \\ 5 & 0 & 12 \\ 30 & 3 & 88 \\ 37 & 0 & 42 \\ 11 & 0 & 10\end{array}$

45
70
93
32
49
102
18
43
15
50
9
77
67
23
15
37
7
12
91
44
122
20
12
88
42
10

$\begin{array}{rrrr}0 & 2 & 0 & 52 \\ 2 & 4 & 1 & 85 \\ 3 & 2 & 1 & 109 \\ 0 & 0 & 0 & 37 \\ 0 & 0 & 2 & 86 \\ 1 & 3 & 3 & 158 \\ 0 & 0 & 0 & 31 \\ 0 & 0 & 0 & 60 \\ 0 & 0 & 0 & 22 \\ 0 & 3 & 2 & 98 \\ 0 & 0 & 0 & 22 \\ 0 & 2 & 2 & 160 \\ 0 & 0 & 0 & 89 \\ 1 & 0 & 0 & 43 \\ 0 & 2 & 0 & 21 \\ 1 & 3 & 1 & 62 \\ 0 & 1 & 0 & 20 \\ 1 & 0 & 0 & 20 \\ 0 & 1 & 2 & 175 \\ 0 & 0 & 0 & 61 \\ 1 & 5 & 0 & 212 \\ 0 & 0 & 0 & 39 \\ 0 & 1 & 0 & 18 \\ 1 & 2 & 1 & 125 \\ 2 & 1 & 1 & 83 \\ 0 & 0 & 0 & 21\end{array}$


Tabel C4 (vervolg)

Ongewogen aantal respondenten verbijzonderd naar bestemming per opleidingsrichting

Opleidingsrichting studie $\quad$ BBL $\begin{array}{r}\text { betald werkloos anders onbekend } \\ \text { werk }\end{array}$

BOL niveau 3/4 (vervolg)

MKF Scheepvaart

MKF Transport en logistiek

MKF Automatisering

MKF Bedrijfsadministratief

MKF Commercieel

MKF Economisch-juridisch

MKF Secretarieel

MKF Detailhandel/ambulante handel

MKF Horeca, instellingskeuken en contractcatering

MKF Toerisme, recreatie en reizen

MKF Assistenten gezondheidszorg

MKF Facilitaire dienstverlening

MKF Sport en bewegen

MKF Verpleging en verzorging

ZB Uiterlijke verzorging

MKF Sociaal-cultureel werker

MKF Sociaal-pedagogisch werk algemeen

MKF Sociaal-juridisch werk

26
5
3
160
108
45
39
139
35
44
45
9
62
196
4
19
414
52

1
0
0
8
3
1
3
5
1
1
7
3
2
87
0
0
33
2

$\begin{array}{rrrrr}65 & 3 & 1 & 0 & 96 \\ 21 & 0 & 0 & 0 & 26 \\ 13 & 0 & 1 & 0 & 17 \\ 148 & 0 & 5 & 2 & 323 \\ 138 & 1 & 5 & 0 & 255 \\ 28 & 1 & 2 & 0 & 77 \\ 139 & 3 & 3 & 0 & 187 \\ 196 & 3 & 6 & 3 & 352 \\ 63 & 1 & 0 & 0 & 100 \\ 90 & 2 & 1 & 0 & 138 \\ 230 & 2 & 5 & 0 & 289 \\ 22 & 0 & 2 & 0 & 36 \\ 63 & 1 & 3 & 0 & 131 \\ 390 & 7 & 20 & 6 & 706 \\ 39 & 1 & 2 & 0 & 46 \\ 30 & 2 & 0 & 1 & 52 \\ 621 & 10 & 26 & 3 & 1.107 \\ 55 & 2 & 3 & 0 & 114\end{array}$

BBL niveau $1 / 2$

BB Bouw

BB Beschermings- en afwerkingstechnieken

BB Constructie(bank)werken/(isolatie)plaatwerken/pijpenbew.

BB Machinebankwerken/verspanen

BB Energie- en informatietechniek

BB Wegvervoer

BB Secretarieel

96
26
17
323
255
77
187
352
100
138
289
36
131
706
46
52
107
114

$\begin{array}{rrrrrrr}0 & 23 & 53 & 0 & 1 & 0 & 77 \\ 0 & 1 & 14 & 0 & 0 & 0 & 15 \\ 1 & 4 & 39 & 1 & 2 & 0 & 47 \\ 0 & 2 & 18 & 0 & 2 & 0 & 22 \\ 0 & 3 & 12 & 0 & 0 & 0 & 15 \\ 1 & 6 & 58 & 0 & 1 & 0 & 66 \\ 0 & 1 & 10 & 2 & 3 & 0 & 16\end{array}$


Tabel C4 (vervolg)

Ongewogen aantal respondenten verbijzonderd naar bestemming per opleidingsrichting

Opleidingsrichting

studie

$\mathrm{BBL}$

betaald

werkloos

anders

onbekend

totaal

BBL niveau 1/2 (vervolg)

BB Detailhandel/ambulante handel

BB Horeca, instellingskeuken en contractcatering

BB Facilitaire dienstverlening

BB Verpleging en verzorging

MKF Bouw

ZB Grond-, water- en wegenbouw

ZB Contructie(bank)werken/(isolatie)plaatwerken/pijpenbew.

MKF Motorvoertuigen

Specialist Energie- en informatietechniek

Specialist Installatie-, service- en onderhoudstechniek

MKF Procestechniek

MKF Automatisering

MKF Detailhandel/ambulante handel

MKF Horeca, instellingskeuken en contractcatering

MKF Verpleging en verzorging

ZB Uiterlijke verzorging

MKF Sociaal-pedagogisch werk

\begin{tabular}{|c|c|c|c|c|c|c|}
\hline 1 & 1 & 72 & 0 & 3 & 2 & 79 \\
\hline 0 & 0 & 19 & 0 & 0 & 0 & 19 \\
\hline 0 & 1 & 16 & 0 & 0 & 0 & 17 \\
\hline 1 & 2 & 28 & 0 & 0 & 0 & 31 \\
\hline 0 & 1 & 20 & 0 & 0 & 0 & 21 \\
\hline 0 & 1 & 24 & 0 & 0 & 0 & 25 \\
\hline 0 & 0 & 19 & 0 & 1 & 0 & 20 \\
\hline 1 & 0 & 15 & 2 & 0 & 0 & 18 \\
\hline 2 & 3 & 44 & 0 & 0 & 1 & 50 \\
\hline 2 & 2 & 34 & 0 & 2 & 0 & 40 \\
\hline 0 & 2 & 78 & 1 & 3 & 1 & 85 \\
\hline 3 & 0 & 14 & 0 & 1 & 1 & 19 \\
\hline 1 & 2 & 50 & 0 & 1 & 0 & 54 \\
\hline
\end{tabular}


Tabel C5

Naar landelijke populatie gewogen aantal schoolverlaters verbijzonderd naar bestemming per opleidingsrichting

\begin{tabular}{|c|c|c|c|c|c|c|c|}
\hline Opleidingsrichting & studie & BBL & $\begin{array}{r}\text { betaald } \\
\text { werk }\end{array}$ & werkloos & anders & onbekend & totaal \\
\hline \multicolumn{8}{|l|}{ VBO } \\
\hline IVBO Landbouw en natuurlijke omgeving & 646 & 286 & 389 & 42 & 33 & 11 & 1.407 \\
\hline IVBO Verzorging & 768 & 258 & 154 & 0 & 377 & 0 & 1.556 \\
\hline Landbouw en natuurlijke omgeving & 2.152 & 503 & 554 & 23 & 66 & 10 & 3.309 \\
\hline Bouwtechniek & 1.519 & 1.122 & 1.574 & 0 & 57 & 142 & 4.413 \\
\hline Mechanische techniek & 752 & 833 & 543 & 42 & 289 & 1 & 2.460 \\
\hline Elektrotechniek & 1.865 & 504 & 1.169 & 50 & 71 & 0 & 3.660 \\
\hline Motorvoertuigentechniek & 523 & 523 & 1.133 & 0 & 0 & 0 & 2.179 \\
\hline Consumptieve techniek & 565 & 627 & 1.067 & 63 & 125 & 0 & 2.447 \\
\hline Administratie & 3.063 & 394 & 888 & 141 & 70 & 30 & 4.587 \\
\hline Verkoop & 1.023 & 187 & 649 & 34 & 82 & 0 & 1.974 \\
\hline Handel & 768 & 119 & 68 & 0 & 105 & 0 & 1.060 \\
\hline Verzorging & 5.706 & 1.315 & 1.334 & 0 & 87 & 46 & 8.488 \\
\hline Uiterlijke verzorging & 279 & 107 & 214 & 21 & 0 & 0 & 621 \\
\hline Mode en kleding & 389 & 22 & 248 & 0 & 0 & 0 & 659 \\
\hline \multicolumn{8}{|l|}{ BOL niveau $1 / 2$} \\
\hline BB Bloemschikken & 5 & 14 & 63 & 9 & 0 & 5 & 95 \\
\hline BB Groene ruimte & 23 & 0 & 64 & 0 & 0 & 0 & 87 \\
\hline BB Houtbewerking en woninginrichting & 9 & 0 & 86 & 0 & 5 & 0 & 100 \\
\hline BB Motorvoertuigen & 92 & 62 & 284 & 0 & 0 & 22 & 460 \\
\hline BB Energie- en informatietechniek & 80 & 60 & 174 & 0 & 0 & 0 & 314 \\
\hline BB Bedrijfsadministratie & 391 & 33 & 749 & 16 & 33 & 16 & 1.238 \\
\hline BB Beveiliging & 38 & 8 & 164 & 0 & 0 & 0 & 210 \\
\hline BB Secretarieel & 298 & 16 & 875 & 90 & 36 & 16 & 1.330 \\
\hline AB Detailhandel/ambulante handel & 152 & 0 & 351 & 0 & 0 & 15 & 518 \\
\hline BB Detailhandel/ambulante handel & 252 & 147 & 1.435 & 65 & 84 & 1 & 1.984 \\
\hline BB Horeca, instellingskeuken en contractcatering & 339 & 242 & 969 & 0 & 0 & 0 & 1.551 \\
\hline BB Verpleging en verzorging & 331 & 310 & 645 & 10 & 39 & 19 & 1.355 \\
\hline
\end{tabular}


Tabel C5 (vervolg)

Naar landelijke populatie gewogen aantal schoolverlaters verbijzonderd naar bestemming per opleidingsrichting

Opleidingsrichting studie $\quad$ BBL $\begin{array}{r}\text { betaald werkloos anders onbekend } \\ \text { werk }\end{array}$

BOL niveau $3 / 4$

ZB Plantenteelt

ZB Veehouderij

ZB Bloemschikken

ZB Groene ruimte

KF Plantenteelt

KF Veehouderij

KF Levensmiddelentechnologie

KF Bloemschikken

KF Dierverzorging en veterinaire ondersteuning

KF Groene ruimte

KF Milieutoezicht

MKF Bouw

MKF Houtbewerking en woninginrichting

MKF Grond-, water- en wegenbouw

MKF Beschermings- en afwerkingstechnieken

MKF Reclame, presentatie en communicatie

MKF Fijnmechanische techniek

MKF Operationele techniek

MKF Werktuigbouwkunde

MKF Motorvoertuigen

MKF Energie- en informatietechniek

MKF Informatietechniek

MKF Scheepsbouwkundige (scheepsbouw)

MKF Grafische techniek, communicatie, audiovisuee

MKF Laboratoriumtechniek

MKF Procestechniek

$\begin{array}{rr}13 & 2 \\ 26 & 0 \\ 20 & 15 \\ 24 & 3 \\ 127 & 0 \\ 183 & 5 \\ 93 & 0 \\ 34 & 15 \\ 33 & 0 \\ 190 & 13 \\ 66 & 0 \\ 773 & 0 \\ 55 & 5 \\ 236 & 0 \\ 7 & 0 \\ 35 & 0 \\ 61 & 0 \\ 14 & 0 \\ 699 & 41 \\ 49 & 3 \\ 964 & 19 \\ 120 & 0 \\ 30 & 0 \\ 164 & 16 \\ 499 & 0 \\ 77 & 0\end{array}$

$\begin{array}{rr}197 & 0 \\ 333 & 12 \\ 287 & 8 \\ 145 & 0 \\ 188 & 0 \\ 392 & 2 \\ 121 & 0 \\ 129 & 0 \\ 70 & 0 \\ 230 & 0 \\ 61 & 0 \\ 754 & 0 \\ 174 & 0 \\ 286 & 12 \\ 27 & 0 \\ 64 & 2 \\ 28 & 0 \\ 24 & 2 \\ 949 & 0 \\ 133 & 0 \\ 1551 & 10 \\ 134 & 0 \\ 63 & 0 \\ 474 & 5 \\ 586 & 30 \\ 82 & 0\end{array}$

220 
Tabel C. 5 (vervolg)

Naar landelijke populatie gewogen aantal schoolverlaters verbijzonderd naar bestemming per opleidingsrichting

Opleidingsrichting studie $\quad$ BBL $\begin{array}{r}\text { betaald werkloos anders onbekend } \\ \text { werk }\end{array}$

BOL niveau 3/4 (vervolg)

MKF Scheepvaart

MKF Transport en logistiek

MKF Automatisering

MKF Bedrijfsadministratief

MKF Commercieel

MKF Economisch-juridisch

MKF Secretarieel

MKF Detailhandel/ambulante hande

MKF Horeca, instellingskeuken en contractcatering

MKF Toerisme, recreatie en reizen

MKF Assistenten gezondheidszorg

MKF Facilitaire dienstverlening

MKF Sport en bewegen

MKF Verpleging en verzorging

ZB Uiterlijke verzorging

MKF Sociaal-cultureel werker

MKF Sociaal-pedagogisch werk algemeen

MKF Sociaal-juridisch werk

63
25
4
1.543
722
400
402
1.348
348
413
195
179
168
964
37
105
2.418
400

$\begin{array}{rr}3 & 159 \\ 0 & 118 \\ 0 & 19 \\ 77 & 1427 \\ 20 & 937 \\ 9 & 249 \\ 43 & 1333 \\ 45 & 1683 \\ 17 & 741 \\ 7 & 855 \\ 32 & 1009 \\ 60 & 436 \\ 5 & 189 \\ 419 & 1905 \\ 0 & 259 \\ 0 & 163 \\ 187 & 3613 \\ 18 & 409\end{array}$

$\begin{array}{rr}7 & \\ 0 & \\ 0 & \\ 0 & 48 \\ 7 & 34 \\ 9 & 18 \\ 32 & 43 \\ 22 & 69 \\ 10 & \\ 18 & 16 \\ 10 & 2 \\ 0 & 40 \\ 2 & 7 \\ 32 & 97 \\ 3 & 15 \\ 6 & \\ 56 & 152 \\ 15 & 27\end{array}$

$\begin{array}{rrr}3 & 0 & 234 \\ 0 & 0 & 143 \\ 1 & 0 & 25 \\ 48 & 19 & 3.115 \\ 34 & 0 & 1.720 \\ 18 & 0 & 685 \\ 43 & 0 & 1.852 \\ 69 & 45 & 3.212 \\ 0 & 0 & 1.116 \\ 16 & 0 & 1.309 \\ 22 & 0 & 1.269 \\ 40 & 0 & 714 \\ 7 & 0 & 371 \\ 97 & 26 & 3.443 \\ 15 & 0 & 314 \\ 0 & 3 & 277 \\ 152 & 8 & 6.434 \\ 27 & 0 & 869\end{array}$

\section{$B B L$ niveau $1 / 2$}

BB Bouw

BB Beschermings- en afwerkingstechnieken

BB Constructie(bank)werken/(isolatie)plaatwerken/pijpenbew.

$\begin{array}{rr}601 & 1212 \\ 34 & 474 \\ 49 & 407 \\ 35 & 255 \\ 25 & 108 \\ 65 & 628 \\ 19 & 123\end{array}$

$\begin{array}{rr}0 & 17 \\ 0 & 0 \\ 8 & 27 \\ 0 & 19 \\ 0 & 0 \\ 0 & 1 \\ 13 & 15\end{array}$

BB Energie-

BB Wegvervoer

$123-13$


Tabel C.5 (vervolg)

Naar landelijke populatie gewogen aantal schoolverlaters verbijzonderd naar bestemming per opleidingsrichting

Opleidingsrichting

studie

$\mathrm{BBL}$

betaald

werkloos

onbekend

totaal

BBL niveau $1 / 2$ (vervolg)

BB Detailhandel/ambulante handel

BB Horeca, instellingskeuken en contractcatering

BB Facilitaire dienstverlening

BB Verpleging en verzorging

0
39

\section{BBL niveau 3/4}

MKF Bouw

ZB Grond-, water- en wegenbouw

ZB Contructie(bank)werken/(isolatie)plaatwerken/pijpenbew.

MKF Motorvoertuigen

Specialist Energie- en informatietechniek

Specialist Installatie-, service- en onderhoudstechniek

MKF Procestechniek

MKF Automatisering

MKF Detailhandel/ambulante hande

MKF Horeca, instellingskeuken en contractcatering

MKF Verpleging en verzorging

ZB Uiterlijke verzorging

MKF Sociaal-pedagogisch werk

$\begin{array}{rrrrrr}226 & 980 & 0 & 38 & 0 & 1.282 \\ 680 & 964 & 0 & 0 & 57 & 1.757 \\ 0 & 153 & 0 & 9 & 74 & 235 \\ 19 & 370 & 17 & 16 & 1 & 462 \\ & & & & & \\ 19 & 897 & 0 & 39 & 21 & 995 \\ 0 & 587 & 0 & 0 & 0 & 587 \\ 7 & 101 & 0 & 0 & 0 & 108 \\ 33 & 447 & 0 & 0 & 0 & 502 \\ 6 & 112 & 0 & 0 & 0 & 118 \\ 25 & 876 & 0 & 0 & 0 & 901 \\ 0 & 286 & 0 & 15 & 0 & 301 \\ 0 & 184 & 26 & 0 & 0 & 223 \\ 51 & 1.033 & 0 & 0 & 21 & 1.144 \\ 42 & 827 & 0 & 51 & 0 & 961 \\ 114 & 4.462 & 57 & 172 & 57 & 4.862 \\ 0 & 530 & 0 & 38 & 38 & 720 \\ 42 & 995 & 0 & 21 & 0 & 1.079\end{array}$


Tabel C.6

Responspercentage per opleidingsrichting

VBO

IVBO Landbouw en natuurlijke omgeving 43

IVBO Bouwtechniek $\quad 25$

IVBO Mechanische techniek $\quad 27$

IVBO Consumptieve techniek

IVBO Verkoop

IVBO Verzorging 34

IVBO Uiterlijke verzorging 13

IVBO Mode en kleding 44

IVBO Algemene voorbereiding op maatschappij en beroep(AVMB)

Landbouw en natuurlijke omgeving

Techniek

Bouwtechniek $\quad 32$

Mechanische techniek 36

$\begin{array}{ll}\text { Elektrotechniek } & 34\end{array}$

Installatietechniek

$\begin{array}{ll}\text { Motorvoertuigentechniek } & 31\end{array}$

Consumptieve techniek

Grafische techniek 19

$\begin{array}{ll}\text { Economie } & 19\end{array}$

Administratie $\quad 38$

Verkoop

Handel $\quad 22$

Gezondheidszorg

Verzorging $\quad 51$

Uiterlijke verzorging $\quad 44$

Mode en kleding $\quad 40$

BOL niveau $1 / 2$

BB Plantenteelt $\quad 30$

BB Veehouderij

BB Levensmiddelentechnologie $\quad 38$

BB Bloemschikken $\quad 58$

$\begin{array}{ll}\text { BB Dierverzorging en veterinaire ondersteuning } & 67\end{array}$

BB Groene ruimte $\quad 64$

BB Bouw $\quad 22$

BB Houtbewerking en woninginrichting $\quad 20$

BB Beschermings- en afwerkingstechnieken

BB Constructie(bank)werken/(isolatie)plaatwerken/pijpenbew. 21

BB Machinebankwerken/verspanen $\quad 50$

BB Montage/onderhoud/operationele techniek 10

BB Motorvoertuigen $\quad 24$

BB Energie- en informatietechniek $\quad 31$

BB Energietechniek $\quad 27$

BB Informatietechniek $\quad 9$

BB Installatie-, service- en onderhoudstechniek 18

BB Grafische techniek, communicatie, audiovisueel $\quad 23$

BB Mode en kleding (realisatie) 33

BB Haven en vervoer $\quad 80$

BB Scheepvaart $\quad 28$

BB Brood- en banketbakken algemeen $\quad 40$

BB Bedrijfsadministratie $\quad 36$

BB Beveiliging $\quad 21$

BB Commercieel $\quad 35$ 
Tabel C.6 (vervolg)

Responspercentage per opleidingsrichting

BOL niveau $1 / 2$ (vervolg)

BB Secretarieel

AB Detailhandel/ambulante handel

BB Detailhandel/ambulante handel

BB Horeca, instellingskeuken en contractcatering

BB Facilitaire dienstverlening

$B B$ Verpleging en verzorging

BB Uiterlijke verzorging

BOL niveau 3/4

ZB Plantenteelt

ZB Veehouderij

ZB Levensmiddelentechnologie

ZB Bloemschikken

ZB Dierverzorging en veterinaire ondersteuning 446

ZB Paardenhouderij en paardensport $\quad 57$

ZB Groene ruimte $\quad 40$

KF Plantenteelt $\quad 50$

KF Veehouderij $\quad 62$

KF Levensmiddelentechnologie $\quad 64$

KF Bloemschikken

KF Dierverzorging en veterinaire ondersteuning $\quad 68$

KF Biologisch-dynamische land- en tuinbouw

KF Paardenhouderij en paardensport $\quad 63$

KF Groene ruimte $\quad 55$

KF Milieutoezicht $\quad 56$

MKF Techniek $\quad 48$

$\begin{array}{ll}\text { MKF Bouw } & 45 \\ \text { MKF Houbewerking en woninginiching } & 33\end{array}$

MKF Houtbewerking en woninginrichting

MKF Grond-, water- en wegenbouw $\quad 42$

MKF Beschermings- en afwerkingstechnieken 40

MKF Reclame, presentatie en communicatie $\quad 52$

MKF Fijnmechanische techniek $\quad 69$

MKF Meet- en regeltechniek $\quad 37$

$\begin{array}{ll}\text { MKF Operationele techniek } & 48\end{array}$

MKF Werktuigbouwkunde $\quad 41$

MKF Motorvoertuigen $\quad 34$

MKF Energie- en informatietechniek 38

MKF Informatietechniek $\quad 31$

MKF Scheepsbouwkundige (scheepsbouw)

MKF Grafische techniek, communicatie, audiovisueel $\quad 40$

MKF Laboratoriumtechniek

$\begin{array}{ll}\text { MKF Milieutechniek } & 40\end{array}$

MKF Procestechniek $\quad 51$

MKF Haven en vervoer $\quad 42$

MKF Scheepvaart $\quad 40$

MKF Transport en logistiek $\quad 39$

MKF Automatisering $\quad 23$

MKF Bedrijfsadministratief $\quad 46$

MKF Commercieel $\quad 39$

MKF Economisch-juridisch

MKF Secretarieel $\quad 52$

MKF Detailhandel/ambulante handel $\quad 39$

$\begin{array}{ll}\text { MKF Groothandel/distributie } & 29\end{array}$ 
Tabel C.6 (vervolg)

Responspercentage per opleidingsrichting

BOL niveau 3/4 (vervolg)

en contractcatering

MKF Toerisme, recreatie en reizen

MKF Assistenten gezondheidszorg

MKF Facilitaire dienstverlening $\quad 40$

MKF Sport en bewegen $\quad 43$

MKF Verpleging en verzorging $\quad 52$

ZB Uiterlijke verzorging $\quad 40$

MKF Mode en kleding (presentatie)

MKF Sociaal-cultureel werker $\quad 37$

MKF Sociaal-pedagogisch werk algemeen $\quad 48$

MKF Sociaal-juridisch werk $\quad 43$

BBL niveau $1 / 2$

BB Bouw

$\begin{array}{ll}\text { BB Houtbewerking en woninginrichting } & 27\end{array}$

BB Grond-, water en wegenbouw

BB Beschermings- en afwerkingstechnieken 16

BB Constructie(bank)werken/(isolatie)plaatwerken/pijpenbew. 32

BB Lassen

BB Machinebankwerken/verspanen 38

BB Meet- en regeltechniek 17

BB Montage/onderhoud/operationele techniek

BB Scheepsbouw (metaal)

BB Werktuigbouwkunde $\quad 29$

BB Carrosserie en wagenbouw $\quad 20$

BB Motorvoertuigen $\quad 17$

BB Energie- en informatietechniek

BB Energietechniek $\quad 29$

BB Installatie-, service- en onderhoudstechniek

BB Grafische techniek, communicatie, audiovisueel $\quad 50$

BB Mode en kleding (realisatie) $\quad 25$

BB Textieltechniek 19

BB Procestechniek 17

BB Haven en vervoer $\quad 22$

BB Wegvervoer $\quad 42$

BB Brood- en banketbakken $\quad 28$

BB Bedrijfsadministratief $\quad 45$

BB Beveiliging $\quad 22$

BB Commercieel $\quad 50$

BB Secretarieel

BB Detailhandel/ambulante handel $\quad 25$

BB Opslag/magazijn 13

BB Horeca, instellingskeuken en contractcatering $\quad 26$

BB Facilitaire dienstverlening

BB Verpleging en verzorging $\quad 34$

BB Uiterlijke verzorging $\quad 25$

BBL niveau $3 / 4$

MKF Techniek 14

MKF Bouw $\quad 32$

MKF Houtbewerking en woninginrichting

ZB Grond-, water- en wegenbouw $\quad 41$ 
Tabel C.6 (vervolg)

Responspercentage per opleidingsrichting

BBL niveau 3/4 (vervolg)

Specialist Beschermings- en afwerkingstechnieken 30

MKF Industriele lakverwerking $\quad 25$

ZB Contructie(bank)werken/(isolatie)plaatwerken/pijpenbew. 40

ZB Instrumenttechniek $\quad 20$

ZB Gereedschapsmaker $\quad 50$

ZB Machinebankwerken/verspanen $\quad 27$

Specialist Werktuigbouwkunde $\quad 50$

Specialist Carrosserie en wagenbouw $\quad 25$

MKF Motorvoertuigen 36

Specialist Energie- en informatietechniek $\quad 25$

Specialist Energietechniek 33

ZB Beheer, ontwerp en management (installatietechniek)

ZB Distributietechniek

BBL Specialist Installatie-, service- en onderhoudstechniek 33

MKF Grafische techniek, communicatie, audiovisueel

$\begin{array}{ll}\text { MKF Procestechniek } & 23 \\ \text { MKF Wegverver } & 32\end{array}$

MKF Wegvervoer

MKF Brood- en banketbakken

MKF Automatisering $\quad 25$

MKF Bedrijfsadministratief $\quad 43$

MKF Commercieel $\quad 27$

MKF Logistiek

MKF Secretarieel

MKF Detailhandel/ambulante handel $\quad 22$

MKF Groothandel/distributie $\quad 25$

MKF Opslag/magazijn $\quad 24$

MKF Horeca, instellingskeuken en contractcatering $\quad 39$

MKF Verpleging en verzorging $\quad 35$

ZB Uiterlijke verzorging

MKF Maatschappelijke dienstverlening

MKF Sociaal-pedagogisch werk 36 
D. Opleidingsindeling 



\section{Overzicht van opleidingen per opleidingssector}

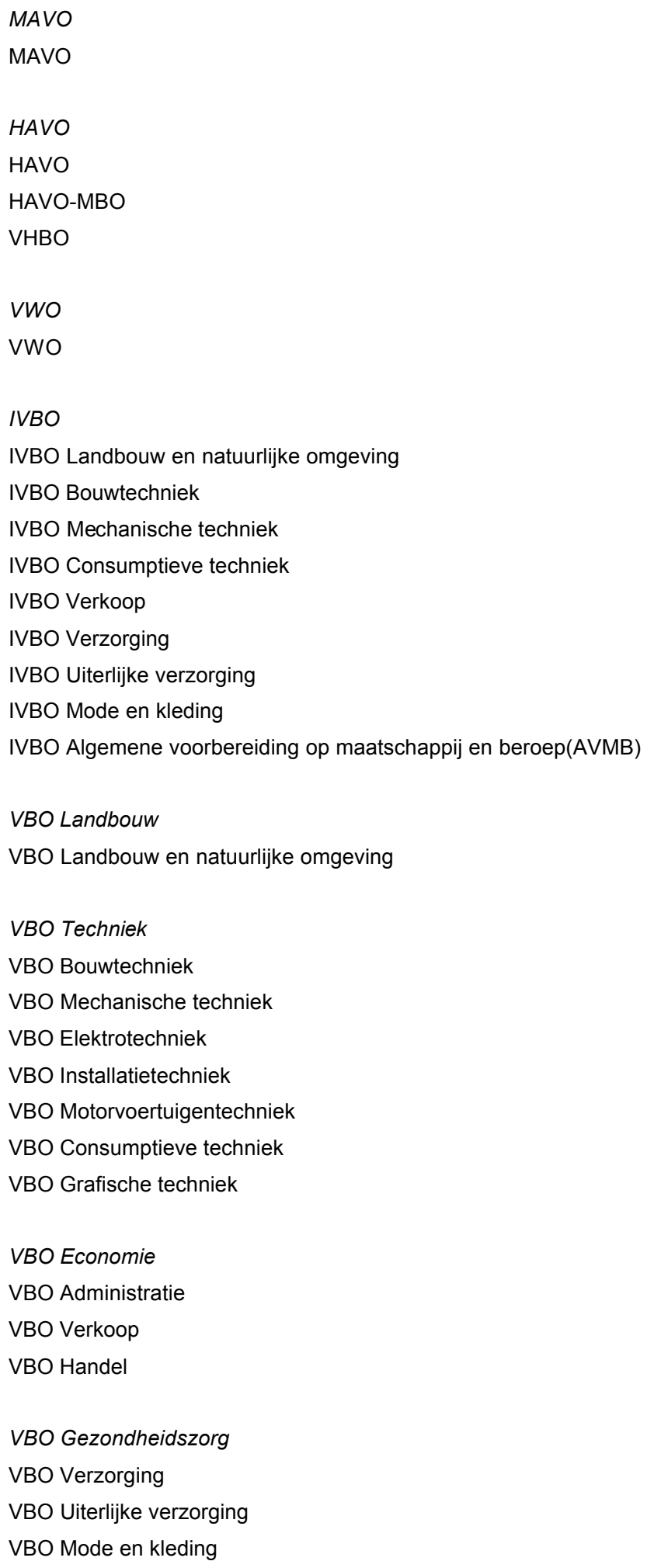


BOL niveau 1/2 Landbouw

BOL BB Plantenteelt

BOL BB Veehouderij

BOL BB Levensmiddelentechnologie

BOL BB Bloemschikken

BOL BB Dierverzorging en veterinaire ondersteuning

BOL BB Paardenhouderij en paardensport

BOL BB Groene ruimte

BOL niveau 1/2 Techniek

BOL BB Bouw

BOL BB Houtbewerking en woninginrichting

BOL BB Beschermings- en afwerkingstechnieken

BOL BB Constructie(bank)werken/(isolatie)plaatwerken/pijpenbew.

BOL BB Machinebankwerken/verspanen

BOL BB Montage/onderhoud/operationele techniek

BOL BB Motorvoertuigen

BOL BB Energie- en informatietechniek

BOL BB Energietechniek

BOL BB Informatietechniek

BOL BB Installatie-, service- en onderhoudstechniek

BOL BB Grafische techniek, communicatie, audiovisueel

BOL BB Mode en kleding (realisatie)

BOL BB Haven en vervoer

BOL BB Scheepvaart

BOL BB Brood- en banketbakken algemeen

BOL niveau 1/2 Economie

BOL BB Bedrijfsadministratie

BOL BB Beveiliging

BOL BB Commercieel

BOL BB Secretarieel

BOL AB Detailhandel/ambulante handel

BOL BB Detailhandel/ambulante handel

BOL BB Horeca, instellingskeuken en contractcatering

BOL niveau 1/2 Gezondheidszorg

BOL BB Facilitaire dienstverlening

BOL BB Verpleging en verzorging

BOL BB Uiterlijke verzorging

BOL niveau 3/4 Landbouw

BOL ZB Plantenteelt

BOL ZB Veehouderij

BOL ZB Levensmiddelentechnologie 
BOL ZB Bloemschikken

$B O L Z B$ Dierverzorging en veterinaire ondersteuning

BOL ZB Paardenhouderij en paardensport

BOL ZB Groene ruimte

BOL KF Plantenteelt

BOL KF Veehouderij

BOL KF Levensmiddelentechnologie

BOL KF Bloemschikken

BOL KF Dierverzorging en veterinaire ondersteuning

BOL KF Biologisch-dynamische land- en tuinbouw

BOL KF Paardenhouderij en paardensport

BOL KF Groene ruimte

BOL KF Milieutoezicht

BOL niveau 3/4 Techniek

BOL MKF Bouw

BOL MKF Houtbewerking en woninginrichting

BOL MKF Grond-, water- en wegenbouw

BOL MKF Beschermings- en afwerkingstechnieken

BOL MKF Reclame, presentatie en communicatie

BOL MKF Fijnmechanische techniek

BOL MKF Meet- en regeltechniek

BOL MKF Operationele techniek

BOL MKF Werktuigbouwkunde

BOL MKF Motorvoertuigen

BOL MKF Energie- en informatietechniek

BOL MKF Informatietechniek

BOL MKF Scheepsbouwkundige (scheepsbouw)

BOL MKF Grafische techniek, communicatie, audiovisueel

BOL MKF Laboratoriumtechniek

BOL MKF Milieutechniek

BOL MKF Procestechniek

BOL MKF Haven en vervoer

BOL MKF Scheepvaart

BOL MKF Transport en logistiek

BOL niveau 3/4 Economie

BOL MKF Automatisering

BOL MKF Bedrijfsadministratief

BOL MKF Commercieel

BOL MKF Economisch-juridisch

BOL MKF Secretarieel

BOL MKF Detailhandel/ambulante handel

BOL MKF Groothandel/distributie

BOL MKF Textielhandel 
BOL MKF Horeca, instellingskeuken en contractcatering

BOL MKF Toerisme, recreatie en reizen

BOL niveau 3/4 Gezondheidszorg

BOL MKF Assistenten gezondheidszorg

BOL MKF Facilitaire dienstverlening

BOL MKF Sport en bewegen

BOL MKF Verpleging en verzorging

BOL ZB Uiterlijke verzorging

BOL MKF Mode en kleding (presentatie)

BOL niveau 3/4 Gedrag en Maatschappij

BOL MKF Sociaal-cultureel werker

BOL MKF Sociaal-pedagogisch werk algemeen

BOL MKF Sociaal-juridisch werk

BBL niveau 1/2 Techniek

BBL BB Bouw

BBL BB Houtbewerking en woninginrichting

BBL BB Grond-, water en wegenbouw

BBL BB Beschermings- en afwerkingstechnieken

BBL BB Constructie(bank)werken/(isolatie)plaatwerken/pijpenbew.

BBL BB Lassen

BBL BB Machinebankwerken/verspanen

BBL BB Meet- en regeltechniek

BBL BB Montage/onderhoud/operationele techniek

BBL BB Scheepsbouw (metaal)

BBL BB Werktuigbouwkunde

BBL BB Carrosserie en wagenbouw

BBL BB Motorvoertuigen

BBL BB Energie- en informatietechniek

BBL BB Energietechniek

BBL BB Informatietechniek

BBL BB Installatie-, service- en onderhoudstechniek

BBL BB Grafische techniek, communicatie, audiovisueel

BBL BB Mode en kleding (realisatie)

BBL BB Textieltechniek

BBL BB Laboratoriumtechniek

BBL BB Procestechniek

BBL BB Haven en vervoer

BBL BB Wegvervoer

BBL BB Brood- en banketbakken

BBL niveau 1/2 Economie

BBL BB Bedrijfsadministratief 
BBL BB Beveiliging

BBL BB Commercieel

BBL BB Secretarieel

BBL BB Detailhandel/ambulante handel

BBL BB Opslag/magazijn

BBL BB Horeca, instellingskeuken en contractcatering

BBL niveau 1/2 Gezondheidszorg

$B B L B B$ Facilitaire dienstverlening

$B B L B B$ Verpleging en verzorging

BBL BB Uiterlijke verzorging

BBL niveau 3/4 Techniek

BBL MKF Techniek

BBL MKF Bouw

BBL MKF Houtbewerking en woninginrichting

BBL ZB Grond-, water- en wegenbouw

BBL Specialist Beschermings- en afwerkingstechnieken

BBL MKF Industriele lakverwerking

BBL ZB Contructie(bank)werken/(isolatie)plaatwerken/pijpenbew.

BBL ZB Gereedschapsmaker

BBL ZB Machinebankwerken/verspanen

BBL Specialist Werktuigbouwkunde

BBL Specialist Carrosserie en wagenbouw

BBL MKF Motorvoertuigen

BBL Specialist Energie- en informatietechniek

BBL Specialist Energietechniek

BBL ZB Beheer, ontwerp en management (installatietechniek)

BBL ZB Distributietechniek

$B B L$ Specialist Installatie-, service- en onderhoudstechniek

BBL MKF Grafische techniek, communicatie, audiovisueel

BBL MKF Procestechniek

BBL MKF Wegvervoer

BBL MKF Brood- en banketbakken

BBL niveau 3/4 Economie

BBL MKF Automatisering

BBL MKF Bedrijfsadministratief

BBL MKF Commercieel

BBL MKF Logistiek

BBL MKF Secretarieel

BBL MKF Detailhandel/ambulante handel

BBL MKF Groothandel/distributie

BBL MKF Opslag/magazijn

BBL MKF Horeca, instellingskeuken en contractcatering 
BBL niveau 3/4 Gezondheidszorg

BBL MKF Verpleging en verzorging

BBL ZB Uiterlijke verzorging

BBL In-service Verpleegkundige $B$

BBL niveau 3/4 Gedrag en maatschappij

BBL MKF Maatschappelijke dienstverlening

BBL MKF Sociaal-pedagogisch werk

HBO Landbouw

HBO Landbouw/produktie

HBO Landbouw/bedrijfskunde

HBO Milieu/groene ruimte

HBO Technologie/laboratorium

HBO Agrarische docentopl.

HBO Onderwijs

HBO Leraar basis-/speciaalonderwijs

HBO Leraar VO taal 1-vak (2e gr.)

HBO Leraar VO maatschappij 1-vak (2e gr.)

HBO Leraar VO expressie 1-vak (2e gr.)

HBO Leraar VO lichamelijke oefening (1e gr.)

HBO Leraar VO exact 1-vak (1e/2e gr.)

HBO Algemene beroepenvariant Hogere kaderopleiding pedagogie

HBO Techniek

HBO Kort Bedrijfskaderopleiding

HBO Bouwkunde

HBO Civiele techniek

HBO Geodesie

HBO Verkeerskunde

HBO Ruimtelijke ordening en planologie

HBO Milieukunde (technisch)

HBO Logistiek en technische vervoerskunde

HBO Elektrotechniek

HBO Hogere informatica

HBO Informatica en informatiekunde

HBO Werktuigbouwkunde

HBO Autotechniek

HBO Luchtvaarttechnologie

HBO Scheepsbouwkunde

HBO Technische natuurkunde

HBO Materiaalkunde

HBO Chemische technologie

HBO Aquatische ecotechnologie 
HBO Milieutechnologie (technische)

HBO Technisch-commerciele confectiekunde

HBO Technische bedrijfskunde

HBO Bouwtechnische bedrijfskunde

HBO Mode-, textielvormgeving en styling

HBO Algemene operationele technologie

HBO Petroleum- en gastechnologie

HBO Hydrografie

HBO Maritiem officier

HBO Vliegtuigoperatie

HBO Analytische proces- en laboratoriuminstrumentatie

HBO Biologische laboratoriumopleiding

HBO Chemische laboratoriumopleiding

HBO Medische laboratoriumopleiding

HBO Laboratoriuminformatica en automatisering

HBO Economie

HBO Kort Hoger toeristisch en recreatief onderwijs

HBO Accountancy

HBO Bedrijfseconomie

HBO Fiscale economie

HBO Hoger onderwijs voor de financiele sector

HBO Bedrijfskundige informatica

HBO Bestuurskunde/overheidsmanagement

HBO Management, economie en recht

HBO Bedrijfswiskunde

HBO Commerciele economie

HBO Logistiek en economie

HBO Economisch-linguistische opleiding

HBO Small business en retail management

HBO Voeding en marketing

HBO Bibliotheek en documentaire informatie

HBO Boekhandel en uitgeverij

HBO Communicatie

HBO Communicatiesystemen

HBO Hogere Europese beroepenopleiding

HBO Journalistiek en voorlichting

HBO Opleiding tolk-vertaler

HBO Orientaalse talen en communicatie

HBO Informatiedienstverlening en -management

HBO Facilitaire dienstverlening

HBO Hoger hotelonderwijs

HBO Hoger toeristisch en recreatief onderwijs

HBO Vrijetijdskunde

HBO Duaal Economie 
HBO Gezondheidszorg

HBO Opleiding tot verpleegkundige

HBO Opleiding verpleegkundige maatschappelijke gezondheidszo

HBO Opleiding van kader in de gezondheidszorg

HBO Bewegingstechnologie

HBO Medisch beeldvormende/radiotherapeutische technieken

HBO Fysiotherapie

HBO Ergotherapie

HBO Logopedie

HBO Optometrie

HBO Voeding en dietetiek

HBO Antroposofische gezondheidszorg

HBO Opleiding mondhygienist

HBO Opleiding tot orthoptist

HBO Bewegingsagogie/psychomotorische therapie

HBO Opleiding podotherapie

HBO Sport en bewegen

HBO Oefentherapie Cesar/Mensendieck

HBO Gedrag en maatschappij

$\mathrm{HBO}$ Creatieve therapie

HBO Culturele en maatschappelijke vorming

HBO Expressie door woord en gebaar

HBO Maatschappelijk werk en dienstverlening

HBO Personeel en arbeid

HBO Sociaal-juridische dienstverlening

HBO Sociaal pedagogische hulpverlening

HBO Hoger pedagogisch en sociaal-agogisch onderwijs

HBO Kunst en cultuur

HBO Kunst en cultuur

HBO Beeldende kunst autonoom

HBO Beeldende kunst toegepast design

HBO Beeldende kunst audiovisueel

HBO Beeldende kunst docerend

HBO Muziek uitvoerend algemeen

HBO Muziek docerend algemeen

HBO Theater uitvoerend

HBO Theater docerend

WO Landbouw

WO Bos- en natuurbeheer

WO Landinrichtingswetenschappen

WO Tropisch landgebruik

WO Plantenteeltwetenschappen 
WO Tuinbouwplantenteelt

WO Plantenveredeling en gewasbescherming

WO Zootechniek

WO Bioprocestechnologie

WO Levensmiddelentechnologie

WO Landbouwtechniek

WO Economie van landbouw en milieu

WO Voeding en gezondheid

WO Rurale ontwikkelingsstudies

WO Huishoud- en consumentenwetenschappen

WO Agrosysteemkunde

WO Bodem, water en atmosfeer

WO Biologie

WO Milieuhygiene

WO Techniek

WO Technische aardwetenschappen

WO Scheikundige technologie en bioprocestechnologie

WO Technische mechanica

WO Technische natuurkunde

WO Technische scheikunde

WO Technische wiskunde

WO Bedrijfsinformatietechnologie

WO Informatietechniek

WO Technische informatica

WO Elektrotechniek

WO Bouwkunde

WO Civiele techniek

WO Civiele technologie en management

WO Geodesie

WO Industrieel ontwerpen

WO Luchtvaart- en ruimtevaarttechniek

WO Maritieme techniek

WO Materiaalkunde

WO Werktuigbouwkunde

WO Werktuigkundige medische technologie

WO Technische bedrijfskunde

WO Technische bestuurskunde

WO Techniek en maatschappij

WO Wijsbegeerte, wetenschap, technologie en samenleving

WO Informatica

WO Economie

WO Economie

WO Beleidsgerichte economie 
WO Economische en historische studies

WO Fiscale economie

WO Internationale economie en economische geografie

WO Recht en economie in bedrijf en maatschappij

WO Sociale en institutionele economie

WO Japankunde

WO Actuariele wetenschappen

WO Bedrijfseconometrie

WO Econometrie

WO Operationele research en management

WO Bestuurlijke informatiekunde

WO Bedrijfskunde

WO Bedrijfswetenschappen

WO Bedrijfskunde van de financiele sector

WO Technische bedrijfswetenschappen

WO Gezondheidszorg

WO Diergeneeskunde

WO Geneeskunde

WO Tandheelkunde

WO Beleid en management gezondheidszorg

WO Bewegingswetenschappen

WO Biomedische gezondheidswetenschappen

WO Biomedische wetenschappen

WO Gezondheidswetenschappen

WO Medische biologie

WO Medische informatiekunde

WO Milieugezondheidkunde

WO Gedrag en maatschappij

WO Cognitiewetenschap

WO Psychologie

WO Sociaal-wetenschappelijke informatica

WO Technische cognitiewetenschap

WO Pedagogische wetenschappen

WO Onderwijskunde

WO Toegepaste onderwijskunde

WO Communicatiewetenschap

WO Toegepaste communicatiewetenschap

WO Algemene sociale wetenschappen

WO Culturele antropologie/Soc niet-Westerse samenlevingen

WO Ontwikkelingsstudies

WO Sociaal-culturele wetenschappen

WO Sociologie

WO Vrijetijdswetenschappen 
WO Arbeid en sociale zekerheid

WO Personeelwetenschappen

WO Recht, bestuur en management

WO Beleids- en organisatiewetenschappen

WO Beleidsgerichte milieukunde

WO Beleidswetenschappen

WO Bestuurs- en organisatiewetenschap

WO Bestuurskunde

WO Politicologie

WO Planologie

WO Sociale geografie

WO Technische planologie

WO Demografie

WO Juridische bestuurswetenschappelijke opleiding

WO Juridisch-politiekwetenschappelijke opleiding

WO Taal en cultuur

WO Griekse en Latijnse talen en culturen

WO Nederlandse taal- en letterkunde

WO Duitse taal- en letterkunde

WO Engelse taal- en letterkunde

WO Franse taal- en letterkunde

WO Italiaanse taal- en letterkunde

WO Keltische talen en cultuur

WO Portugese taal- en letterkunde

WO Roemeense taal- en letterkunde

WO Romaanse talen en culturen

WO Scandinavische talen en hun letterkunde

WO Spaanse taal- en letterkunde

WO Talen en culturen van Latijns Amerika

WO Afrikaanse taalkunde

WO Arabische, Nieuwperzische en Turkse talen en culturen

WO Chinese talen en culturen

WO Egyptische taal en cultuur

WO Finoegrische talen en letterkunde

WO Indische en Iraanse talen en culturen

WO Talen en culturen van Zuidoost-Azie en Oceanie

WO Japanse taal en cultuur

WO Nieuwgriekse taal- en letterkunde

WO Semitische talen en culturen

WO Slavische talen en hun letterkunde

WO Talen en culturen van Indiaans Amerika

WO Vergelijkende Indo-Europese taalwetenschap

WO Alfa-informatica

WO Algemene letteren 
WO Algemene literatuurwetenschap

WO Algemene taalwetenschap

WO Letteren

WO Spraak- en taalpathologie

WO Vertaalwetenschap

WO Toegepaste taalwetenschap

WO Afrikanistiek

WO Amerikanistiek

WO Duitslandstudies

WO Europese studies

WO Mediterrane studies

WO Oost-europese studies

WO Ruslandkunde

WO Bedrijfscommunicatie letteren

WO Boek- en informatiewetenschap

WO Communicatiekunde

WO Taal, informatie en communicatie

WO Toegepaste taalkunde

WO Beleid en bestuur internationale organisaties

WO Culturele studies

WO Cultuur- en mentaliteitsgeschiedenis

WO Cultuur- en wetenschapsstudies

WO Film- en opvoeringskunsten

WO Film- en televisiewetenschappen

WO Kunst- en cultuurwetenschappen

WO Muziekwetenschap

WO Taal- en cultuurstudies

WO Theater-, film- en televisiewetenschappen

WO Vergelijkende kunstwetenschap: woord en beeld

WO Algemene opleiding godgeleerdheid

WO Godgeleerdheid

WO Godsdienstwetenschappen

WO Levensbeschouwingen

WO Religiestudies

WO Archeologie

WO Europese archeologie

WO Geschiedenis

WO Kunstgeschiedenis en archeologie

WO Maatschappijgeschiedenis

WO Medievistiek

WO Oudheidkunde

WO Wijsbegeerte

WO Wijsbegeerte op basis niet wijsgerige propedeuse

WO Wijsbegeerte van een bepaald wetenschapsgebied 
WO Recht en openbare orde

WO Internationaal en Europees recht

WO Nederlands recht

WO Nederlands recht, internationale/Europees rechtelijke opl

WO Notariele opleiding

WO Fiscaal-juridische opleiding

WO European Law school

WO Europees-juridische opleiding

WO Internationaal recht

WO Internationaal-juridische opleiding

WO Juridische bestuurswetenschappelijke opleiding

WO Natuurwetenschappen

WO Medische biologie

WO Bedrijfs- en industriele statistiek

WO Wiskunde

WO Bedrijfsgerichte informatica

WO Bedrijfsinformatica

WO Bedrijfsinformatiesystemen

WO Bedrijfswiskunde en informatica

WO Cognitieve kunstmatige intelligentie

WO Computational science

WO Kennistechnologie

WO Kunstmatige intelligentie

WO Technische informatica

WO Technisch gerichte informatica

WO Natuurkunde

WO Sterrrenkunde

WO Geochemie

WO Geofysica

WO Geologie

WO Meteorologie en fysische oceanografie

WO Fysische geografie

WO Scheikunde

WO Biofarmaceutische wetenschappen

WO Farmacie

WO Farmacochemie

WO Biologie

WO Fundamentele biomedische wetenschappen

WO Milieubiologie

WO Milieukunde

WO Natuurwetenschappelijke milieukunde

WO Milieuwetenschappen/aardwetenschappen

WO Milieuwetenschappen/biologie

WO Milieuwetenschappen/natuurkunde 
WO Natuurwetenschappen

WO Wetenschapsdynamica

WO Moleculaire wetenschappen 